GROUND-WATER RESOURCE ASSESSMENT OF THE MONTAUK AREA,

LONG ISLAND, NEW YORK

by Keith R. Prince

U.S. GEOLOGICAL SURVEY

Water-Resources Investigations Report 85-4013

Prepared in cooperation with the

SUFFOLK COUNTY WATER AUTHORITY AND

SUFFOLK COUNTY DEPARTMENT OF HEALTH SERVICES

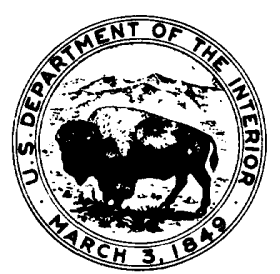

Syosset, New York 
UNITED STATES DEPARTMENT OF THE INTERIOR

DONALD PAUL HODEL, Secretary

GEOLOGICAL SURVEY

Dallas L. Peck, Director

For additional information write to:

U.S. Geological Survey

5 Aerial Way

Syosset, New York 11791

Telephone: (516) 938-8830
Copies of this report may be purchased from:

Open-File Services Section Western Distribution Branch U.S. Geological Survey Box 25425, Federal Center Denver, Colo. 80225

Telephone: (303) 234-5888 
Abstract. . . . . . . . . . . . . . . . . . . 1

Introduction. . . . . . . . . . . . . . . . . . . 2

Purpose and scope....................... 3

Previous investigations. . . . . . . . . . . . . . . 3

Acknowledgments. . . . . . . . . . . . . . . . 4

Hydrogeology. . . . . . . . . . . . . . . . . . . . 5

Bedrock and Cretaceous deposits. . . . . . . . . . . . 6

Post-Cretaceous(?) and P1eistocene deposits. . . . . . . . 8

Post-Cretaceous(?) deposits .............. 9

Marine clay ...................... . 9

Lower unit of stratified drift............... 10

Undifferentiated deposits of till and stratified drift. . . 12

Holocene deposits. . . . . . . . . . . . . . 13

Hydrology . . . . . . . . . . . . . . . . . . . . 14

Ground-water system boundaries . . . . . . . . . . . . 14

Freshwater/saltwater interface. . . . . . . . . . . 14

Confining units..................... 15

Marine clay unit.................. 15

Till unit. . . . . . . . . . . . .... 15

Occurrence of ground water ................... 15

Water in the till unit................. 16

Water in the principal aquifer............. 17

Surface-water features . . . . . . . . . . . . . 20

Marshes........................ 20

Streams . . . . . . . . . . . . . . . . 20

Ponds . . . . . . . . . . . . . . . . . . 23

Recharge to the principal aquifer................. 23

Precipitation ................... 24

Evapotranspiration. . . . . . . . . . . . . . 26

Direct runoff . . . . . . . . . . . . . . . 27

Discharge from the principal aquifer . . . . . . . . . . 28

Freshwater/saltwater relationships . . . . . . . . . . . . 30

Depth of freshwater/saltwater interface . . . . . . . 31

Movement of freshwater/saltwater interface......... . 34

Effects of pumping. . . . . . . . . . . . . . 36

Hydraulic characteristics of the principal aquifer . . . . . . . 40

Determination from specific-capacity data . . . . . . 40

Determination from pumping test . . . . . . . . . . 42

Geologic setting... . . . . . . . . . . 42

Well construction. . . . . . . . . . . . 42

Procedures and observations. . . . . . . . . 42

Graphic analysis ................. 44

Numerical-model analysis of pumping test. . . . . . . 45

Description of model .. . . . . . . . . . 46

Model calibration. ................. 46

Development of Montauk regional flow mode1. . . . . . . . . . 50

Model design . . . . . . . . . . . . . . . . . . 50

Boundary conditions. . . . . . . . . . . . . . . . . 51

Upper boundary. . . . . . . . . . . . . . . . . 51

Lower boundary. . . . . . . . . . . . . 51 


\section{CONTENTS (continued)}

\section{Page}

Lateral boundary. . . . . . . . . . . . . 52

Fresh surface-water bodies. . . . . . . . . . . 53

Model calibration and sensitivity analysis........... 55

Aquifer geometry. . . . . . . . . . . . . 56

Hydraulic conductivity. . . . . . . . . . . . 57

Head-dependent boundary leakage . . . . . . . . . 57

Calibration results . . . . . . . . . . . . . 58

Potentiometric surface .............. 58

Freshwater/saltwater interface . . . . . . . 59

Regional model acceptance. . . . . . . . . . . . . . . 64

Comparison of predevelopment and current ground-water conditions . 66

Effects of future ground-water development. . . . . . . . . 68

Planned development (1995).............. . . 68

Modeled stress. . . . . . . . . . . . . 69

Model results .................... 69

Sustained peak pumpage . . . . . . . . . . . . . . 70

Modeled stress. . . . . . . . . . . . . . . 71

Model results . . . . . . . . . . ........ 74

Conclusions from model studies . . . . . . . . . . . . 76

Site-specific considerations. . . . . . . . . . . . . . . . 78

Limitations in modeling local stresses . . . . . . . . . . . 78

Limitations in modeling the freshwater/saltwater interface . . . 79

Saltwater upconing . . . . . . . . . . . . . . . . 79

Method of investigation . . . . . . . . . . . . 80

Dimensionless analysis of brine coning in Montauk area. . . 81

Conclusions from the dimensionless analysis . . . . . . . 84

Assessment of freshwater availability . . . . . . . . . . . 86

Effects of well placement. . . . . . . . . . . . . 87

Effects of well design ................... 87

Effects of future development. . . . . . . . . . . . . 88

Summary and conclusions . . . . . . . . . . . . . . . . 88

References cited. . . . . . . . . . . . . . . . . . 9 90

\section{ILLUSTRATIONS}

Figure 1. Map showing location of study area and village of Montauk. . 2

2. Map showing major geographic features of study area. . . . 4

3. Generalized geologic section of the Montauk area . . . . . 6

4. Map showing altitude of the top of the marine clay unit. . 10

5. Map showing altitude of the base of the undifferentiated deposits of till and stratified drift and location of unconfined areas of principal aquifer. . . . . . . . 


\section{ILLUSTRATIONS (continued)}

Page

Figure 6. Generalized hydrogeologic section showing the interface between freshwater and saltwater in a coastal aquifer. . . 15

7. Generalized hydrogeologic section of aquifer showing an area confined by the till unit and an area under unconfined conditions ..................... 16

8. Graphs showing water levels in two wells approximately $50 \mathrm{ft}$ apart in the central Montauk area: A. Well S70620, screened in till unit. B. Well S70258, screened in the underlying principal aquifer . . . . . . . . . 17

9. Map showing potentiometric surface of the principal aquifer during March-April 1982................ 18

10. Hydrographs of wells screened in the principal aquifer, 1974-82. . . . . . . . . . . . .... 21

11. Graphs showing precipitation in Montauk area, 1960-83:

A. Annual average. B. Monthly average . . . . . . 24

12. Graph showing annual precipitation at Bridgehampton, 1931-82. . . . . . . . . . . . . . . 25

13. Map showing water-supply distribution. . . . . . . . 28

14. Graph showing monthly ground-water-withdrawal rates by Suffolk County Water Authority, 1981 . . . . . . . 30

15. Map showing altitude of the freshwater/saltwater interface - 32

16. Map showing thickness of freshwater in the principal aquifer. . . . . . . . . . . . . . . 34

17. Cross section showing response of freshwater/saltwater interface to heavy ground-water pumping. . . . . . . . 37

18. Graph showing chloride concentration and pumpage at Suffolk County Water Authority well S30207 in 1981 . • • • 38

19. Graphs showing chloride concentrations from early 1970's through 1982 at three public-supply wells. . . . . . . 39

20. Geologist's $\log$ and gamma-ray $\log$ of production well S57357 near Montauk. . . . . . . . . . . . 43

21. Diagrams showing generalized hydrogeologic section of modeled pumping-test site: A. Major units and initial values used in model. B. Finite-element grid over same area . . . . . . . . . . . . . . . 4 47 


\section{ILLUSTRATIONS (continued)}

Figure 22. Graphs showing observed and simulated water levels at observation well $52 \mathrm{ft}$ from production well during pumping test at Montauk, May 11-12, 1982: A. Drawdown.

B. Recovery . . . . . . . . . . . . . 48

23. Diagram of finite-difference grid for ground-water flow model of the Montauk area. . . . . . . . . . . 51

24. Diagram of model representation of shoreline head-dependent leakage-boundary block . . . . . . . . . . 52

25. Map showing comparison of observed and simulated potentiometric surface of the principal aquifer. . . . . 60

26. Map showing comparison of observed and simulated altitude of the freshwater/saltwater interface. . . . . . . 62

27. Map showing the simulated potentiometric surface of the principal aquifer under predevelopment conditions. . . . . 64

28. Map showing simulated altitude of the freshwater/saltwater interface under predevelopment conditions. . . . . . . 66

29. Map showing proposed location of public-supply we1ls in the Montauk area, 1995 . . . . . . . . . . . 68

30. Map showing predicted 1995 potentiometric surface of the principal aquifer. . . . . . . . . . . . 70

31. Map showing predicted 1995 altitude of the freshwater/ saltwater interface. . . . . . . . . . . . 72

32. Map showing predicted potentiometric surface of the principal aquifer at double the projected 1995 stress. . . 74

33. Map showing predicted altitude of the freshwater/ saltwater interface at double the projected 1995 stress. • 76

34. Diagram showing dimensionless flow nets for a flow-net constant of 0.0256 . A. Fractional screen elevation at 0.65 . B. Fractional screen elevation at 0.85 . . . . 82

35. Graph showing dimensionless specific-capacity function in relation to elevation of screen bottom for maximum stable coning. . . . . . . . . . . . . 84

36. Graph showing maximum permissible discharge function in relation to screen-bottom altitude........... 85 


\section{TABLES}

Page

Table 1. Summary of geologic and hydrogeologic units in the Montauk

area................... . . 7

2. Discharge of selected streams on the Montauk peninsula,

1980-82 . . . . . . . . . . . . . . . . 22

3. Pan evaporation at Greenport, Long Island, 1977-81. • • • 27

4. Major estimated ground-water withdrawals in the Montauk area, 1977-81 . . . . . . . . . . . . . . . 29

5. Chloride concentrations from wells screened in or near the freshwater/saltwater interface. . . . . . . . . . 36

6. Horizontal hydraulic conductivity of the principal aquifer in the Montauk area ............... 41

7. Drawdown and recovery data from 12-hour pumping test,

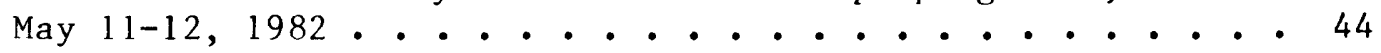

8. Hydraulic values used in simulation of pumping-test drawdown and recovery .............. . 49

9. Comparison of hydraulic values obtained from four sources • 49

10. Water-budget summary for four major ponds in the Montauk area.................... . 54

11. Water levels in the Montauk area........... 94

\section{PLATES}

(in pocket)

Plate 1. Map showing location of wells, streamflow-measurement sites and hydrogeologic cross sections.

2. Hydrogeologic sections $A-A^{\prime}, B-B^{\prime}, C-C^{\prime}$, and $D^{-} D^{\prime}$. 


\section{CONVERSION FACTORS AND ABBREVIATIONS}

For readers who may prefer to use metric (International System) units rather than the inch-pound units used in this report, values may be converted by using the following factors:

\section{Multiply inch-pound unit}

inch (in)

feet $(f t)$

miles ( $\mathrm{mi}$ )

square miles $\left(\mathrm{mi}^{2}\right)$

cubic feet per second $\left(\mathrm{ft}^{3} / \mathrm{s}\right)$

gallons per minute per foot [ (ga 1/min)/ft]

feet per day ( $f t / d)$

millimeter (mm)

centimeter $(\mathrm{cm})$

gram ( $\mathrm{g})$

degrees Celsius $\left({ }^{\circ} \mathrm{C}\right)$ by

$$
\begin{aligned}
& 2.54 \\
& 0.3048 \\
& 1.609 \\
& 2.59 \\
& 28.32 \\
& 0.02832 \\
& 0.01923 \\
& 0.3048
\end{aligned}
$$

\section{$\underline{\text { SI Units }}$}

0.03937
0.3937
0.03527
$1.8\left({ }^{\circ} \mathrm{C}\right)+32$

inch (in)

inch (in)

ounce (oz)

degrees Fahrenheit $\left({ }^{\circ} \mathrm{F}\right)$

\section{Other Abbreviations}

Milligrams per liter (mg/L)

Micrograms per liter $(\mu \mathrm{g} / \mathrm{L})$

Millions of gallons per day (Mgal/d) 


\title{
GROUND-WATER RESOURCE ASSESSMENT OF THE MONTAUK AREA, LONG ISLAND, NEW YORK
}

\author{
By Keith R. Prince
}

\begin{abstract}
The water resources of the Montauk area were investigated from October 1980 through September 1983 to assess the availability of fresh ground water. The principal aquifer, which consists of fine- to coarse-grained stratified glacial drift, is the sole source of freshwater. It is bounded by an underlying marine clay unit, possibly the Gardiners(?) Clay, and an overlying discontinuous unit of generally low permeability known as the upper unit of undifferentiated till and stratified drift, which confines most of the principal aquifer. The freshwater/saltwater interface lies as much as 150 feet below sea level, but the till unit and the marine-clay unit limit the thickness of the zone from which freshwater may easily be withdrawn to less than 100 feet in most places.

Precipitation, the sole source of freshwater in the Montauk area, averages about 42 inches per year. Direct runoff is approximately 1 inch per year, and evapotranspiration is approximately 20 inches per year; the remaining 21 inches is the net recharge to the principal aquifer.

The horizontal hydraulic conductivity, as calculated from specificcapacity data, ranges from 130 to 350 feet per day (ft/d). Analysis of an aquifer-pumping test indicates that horizontal hydraulic conductivity of the principal aquifer is approximately $275 \mathrm{ft} / \mathrm{d}$ and the vertical hydraulic conductivity is approximately $90 \mathrm{ft} / \mathrm{d}$; the storage coefficient ranges from $1.1 \times 10^{-3}$ to $2.2 \times 10^{-3}$.
\end{abstract}

A numerical two-dimensional flow model that simulates the areal flow of fresh- and saltwater was developed to evaluate the effects of the present level of ground-water development and the potential effects of increased future withdrawals. Model results indicate that the principal aquifer is capable of producing several times more than the 0.6 million gallons per day now being withdrawn for public supply.

At present, some saltwater upconing to public-supply wells occurs during periods of heavy pumping. Examination of well design and pumping rates, and analysis of analog-model studies of saltwater upconing to wells, indicate that the peak pumping rate of public-supply wells exceeds the limit necessary to avoid contamination from saltwater. With proper well design and distribution of pumping stress, the aquifer system would be capable of supplying enough water to meet the needs of the population projected through 1995. 


\section{INTRODUCTION}

The Montauk peninsula, at the extreme eastern end of Long Island's south fork (fig. 1), is a popular resort area that draws tens of thousands of vacationers annually. The permanent population is only a few thousand; thus, the seasonal increase in population imposes a large fluctuating demand on the ground-water system. Recent pressure to develop the area further with motels, condominiums, cluster housing, and individual houses has caused concern among water-supply managers and citizens as to whether or not the ground-water system can meet the increased demand for water.

The sole source of fresh ground water on the peninsula is a series of Pleistocene glacial deposits that are bounded below and laterally by salty ground water and surface water. During periods of heavy ground-water pumping in the village of Montauk (fig. 1), operation of public-supply wells is staggered to reduce upconing of saline water and thereby prevent the chloride concentration from exceeding the limit $(250 \mathrm{mg} / \mathrm{L})$ recommended by the U.S. Environmental Protection Agency (1975).

The area of study encompasses approximately $18 \mathrm{mi}^{2}$ east of Napeague Harbor and includes the Hither Hills area, the village of Montauk, Ditch Plains, Prospect Hill, and Montauk Point (fig. 2). The Montauk peninsula can be visualized as three landmasses--Hither Hills, between Napeague Harbor and Fort Pond in the west, the area between Fort Pond and Lake Montauk in the middle, and the area from Lake Montauk to Montauk Point in the east (fig. 2). The Montauk peninsula is bounded on the south and east by the Atlantic Ocean, on the north by Block Island Sound, Fort Pond Bay, and Napeague Bay, and on the west by Napeague Harbor. The peninsula is connected to the rest of Long Island's south fork by a narrow strip of 1 and less than $1 / 2 \mathrm{mi}$ wide and $4 \mathrm{mi}$ long between Napeague Harbor and the Atlantic Ocean.

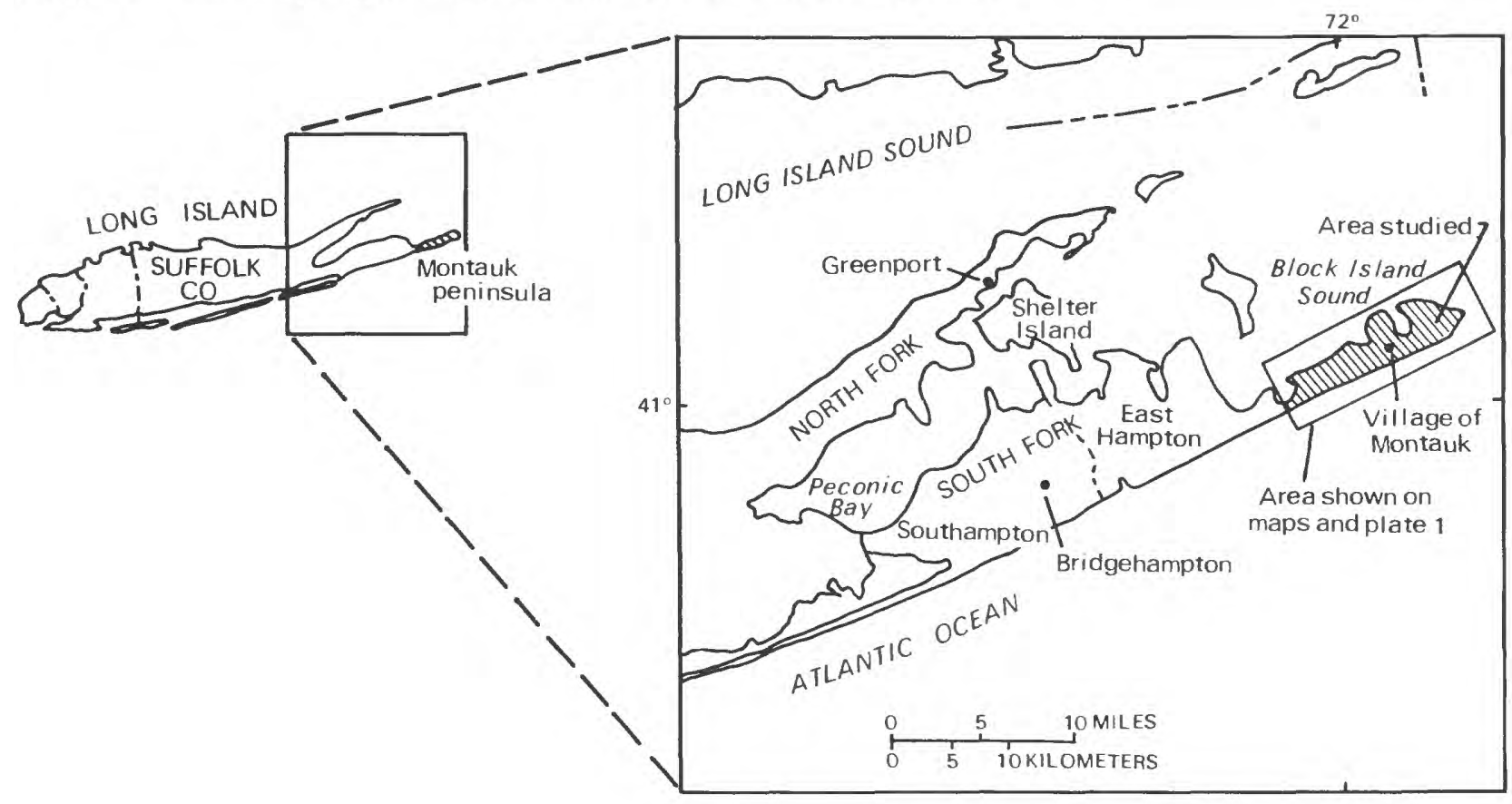

Figure 1.--Location of the study area (shaded) and village of Montauk. 
The permanent population of the Montauk peninsula is estimated to be about 2,800 (U.S. Bureau of Census, 1982). The heaviest demand for water is during summer, when the population on any given day may be as much as 19,300 , as estimated from the number of permanent residents, summer homes, motel rooms, and the average occupancy rate (Nassau-Suffolk Regional Planning Board, oral commun., 1983).

In addition to the demand for freshwater by the tourists, the number of permanent residents is growing as vacant land is developed. Projections by the Nassau-Suffolk Regional Planning Board indicate that the permanent population will reach 4,000 by 1995 . If all vacant land were developed at maximum zoned density and occupied year round, the permanent population would be 20,800 (Long Island Regional Planning Board, 1978).

\section{Purpose and Scope}

This investigation was conducted from October 1980 through September 1983 to develop an understanding of the ground-water system in the Montauk area and its response to stress. Objectives of the study were to: (1) evaluate the availability, occurrence, and movement of fresh ground water; (2) delineate the extent and thickness of the aquifer and evaluate its hydrologic characteristics; ( 3 ) delineate the position of the freshwater/saltwater interface and evaluate its current rate of movement in response to pumping stress; and (4) from results of previous analog-model studies, evaluate the relationship between well location and design and saltwater upconing.

A two-dimensional areal ground-water flow model was developed and calibrated to simulate response of both the potentiometric surface and the freshwater-saline water interface to seasonal fluctuations and pumping. The model was then used to test and refine concepts about the ground-water flow regime and to predict the response of freshwater heads and the saltwater interface to future increases in pumpage.

This report describes the hydrologic setting and ground-water development under 1982 conditions and includes maps showing the potentiometric-surface altitude and saltwater-interface location in 1982 and as predicted by the model for various rates of ground-water pumpage. Plate 1 shows well locations; plate 2 shows hydrogeologic sections through the Montauk area. Well records are given in table 11 (at end of report).

\section{Previous Investigations}

A description of the geology of the Montauk area, specifically the Pleistocene units, and a surficial geologic map, are given in Fuller (1914). More detailed information on the subsurface geology is presented in Suter, delaguna, and Perlmutter (1949). Several more recent investigations have provided information on the geology and hydrology of the area. Perlmutter and Deluca (1963) investigated the availability of freshwater in and around the now-abandoned Montauk Point Air Force Base. Holzmacher, McLendon, and Murrel1 (1968) described the water resources of Suffolk County. Jensen and Soren (1974) presented maps depicting the hydrology of Suffolk County, but most of the data in the Montauk area were inferred. Neiter, Nemickas, Koszalka, and 
Newman (1975) described the Pleistocene deposits of the south fork. Hydrologic data from investigations that include the Montauk area can be found in reports by Bart and others (1976) and Nemickas, Koszalka, and Vaupe1 (1977). The hydrology of the south fork, including the Montauk area, has been described in Fetter $(1971,1976)$ and by Nemickas and Koszalka (1982).

\section{Acknowledgments}

Many agencies and individuals helped collect, compile, and analyze data, especially the Suffolk County Water Authority, Suffolk County Department of Health Services (particularly Steven Cary and "Phil" Bucher), Suffolk County Department of Parks, the Long Island State Park and Recreation Commission, and Hither Hills State Park superintendent George Larsen. The author extends special thanks to Thomas E. Reilly of the U.S. Geological Survey for technical guidance in the ground-water modeling phase of the investigation.

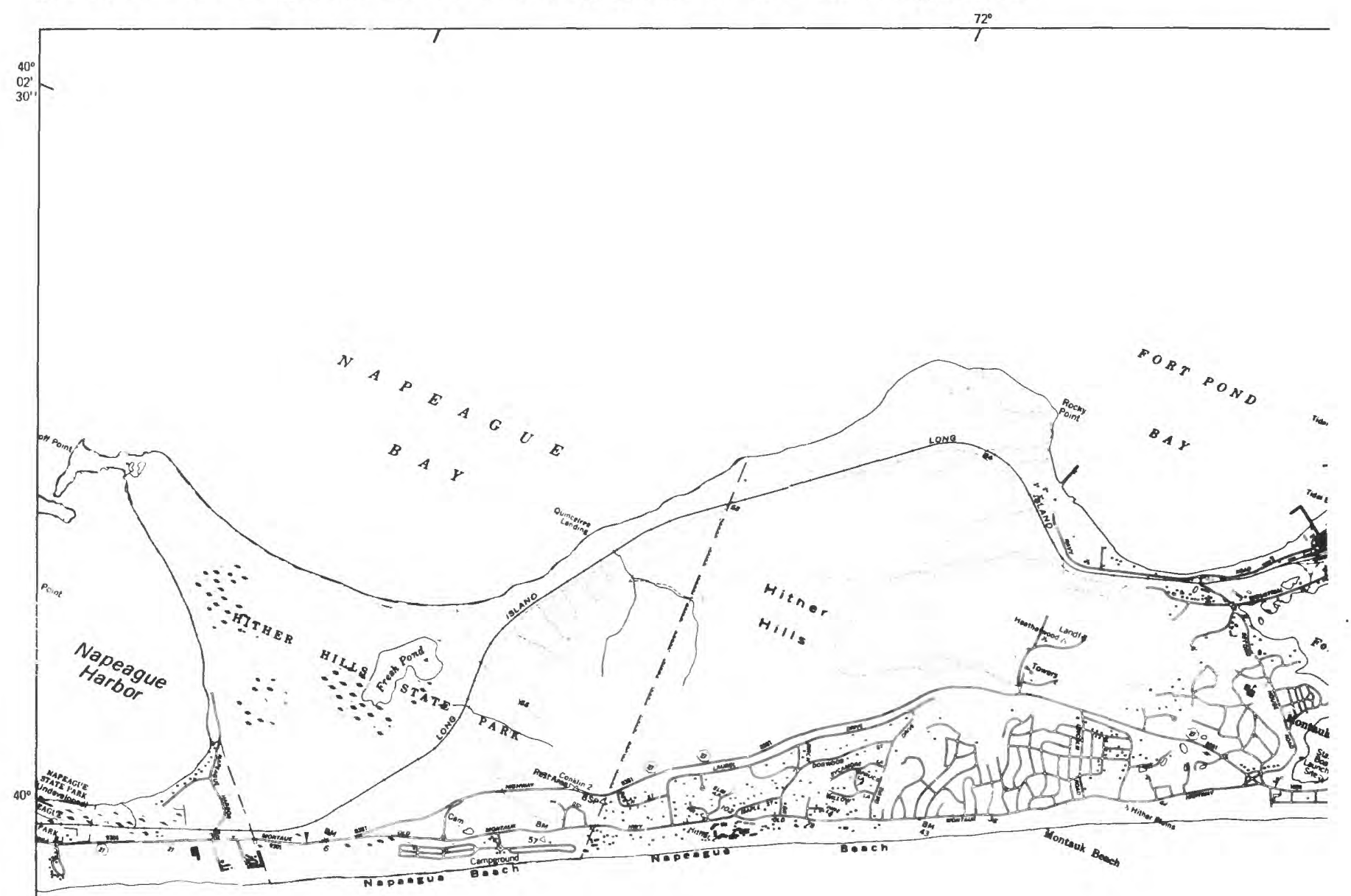

ATLANTIC 


\section{HYDROGEOLOGY}

The topography of the Montauk area is dominated by the Ronkonkoma terminal moraine--a line of hills that traverses the length of Long Island. Land-surface altitude in the area ranges from sea level to about $170 \mathrm{ft}$ above sea leve1; the area is characterized by knob-and-kettle terrain. Much of the south shore of the Montauk area and the north shore of Hither Hills is bordered by steep, wave-cut bluffs that rise to as much as $80 \mathrm{ft}$ above sea leve1; elsewhere the land surface slopes more gradually. Freshwater ponds have developed in kettleholes that were formed by the melting of ice blocks that had been covered by glacial deposits. Fresh Pond in Hither Hills and Fort Pond (fig. 2) are examples. Lake Montauk, a dominant feature of the area, is a tidal harbor open to Block Island Sound to the north.

The stratigraphy of the Montauk area is similar to that of the south fork and other areas in Suffolk County and is described in detail in reports by Nemickas and Koszalka (1982), Jensen and Soren (1974), Perlmutter and DeLuca (1963), and Suter, deLaguna, and Perlmutter (1949).
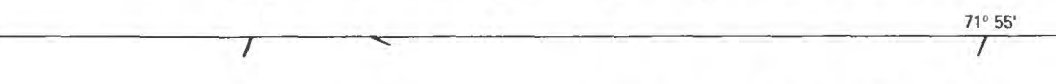

\section{BLOCK ISLAND SOUND}

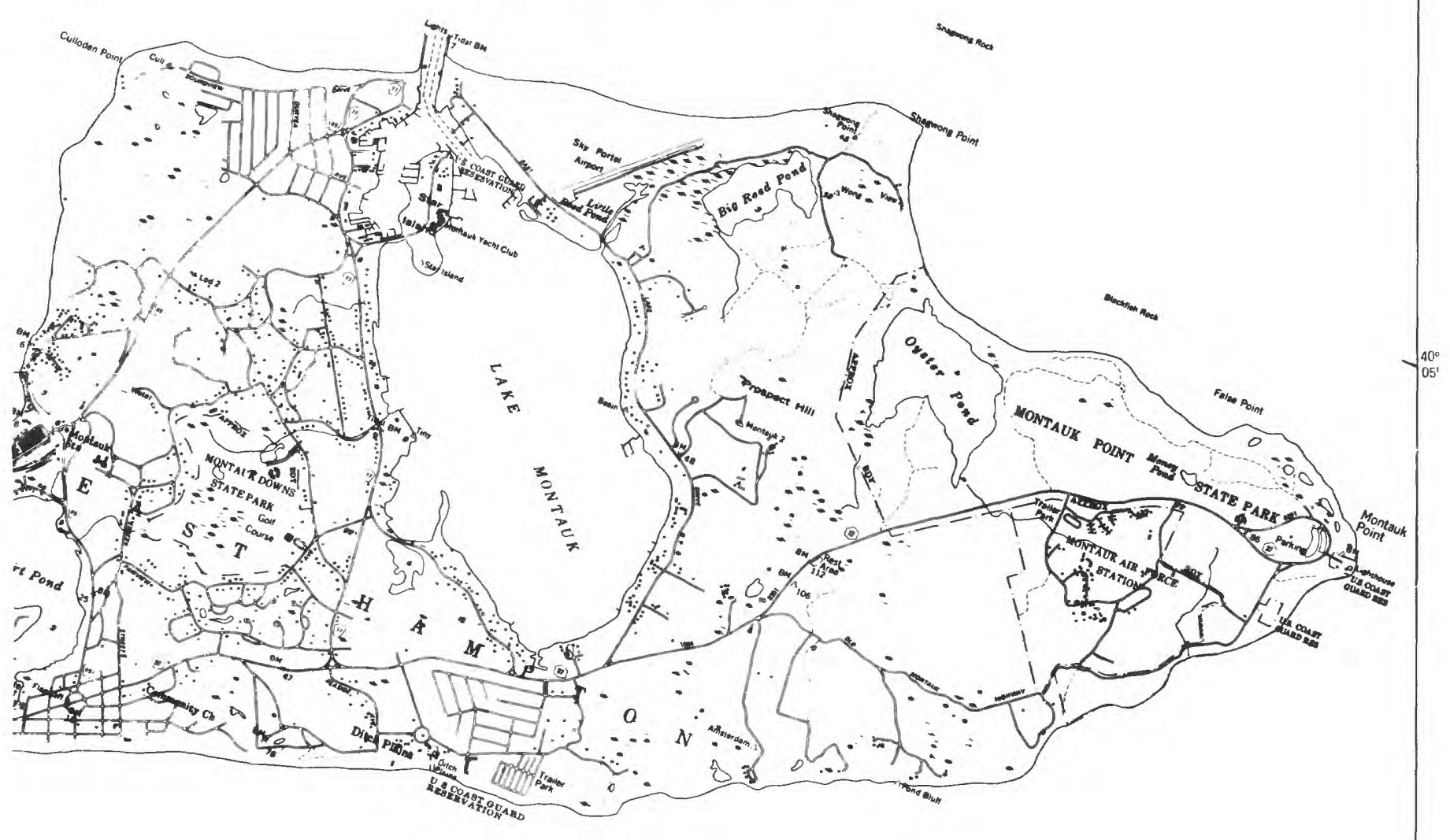

OCEAN

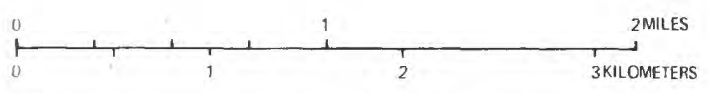

features of study area. 
The area is underlain by a thick sequence of unconsolidated sedimentary deposits of Cretaceous and Quaternary age 1ying unconformably on Precambrian and Paleozoic crystalline bedrock ( $f i g .3$ ). The Cretaceous deposits are, in ascending order, (1) the Raritan Formation of Late Cretaceous age, which consists of the Lloyd Sand Member and an unnamed clay member, and (2) the Magothy Formation and Matawan Group, undifferentiated, which consists of sand and clay. Unconformably overlying the Magothy-Matawan sequence are postCretaceous(?) and Pleistocene deposits, which in ascending order consist of several units--the post-Cretaceous(?) deposits of sand and gravel reported by Nemickas and Koszalka (1982), a marine clay unit, stratified drift and the Montauk Till Member of the Manhasset Formation, and the Ronkonkoma Drift. Holocene deposits consist of recent shore, beach, and marsh deposits. A generalized geologic section is shown in figure 3; a summary of geologic and hydrogeologic units in the Montauk area is given in table 1 .

NORTH

Montauk

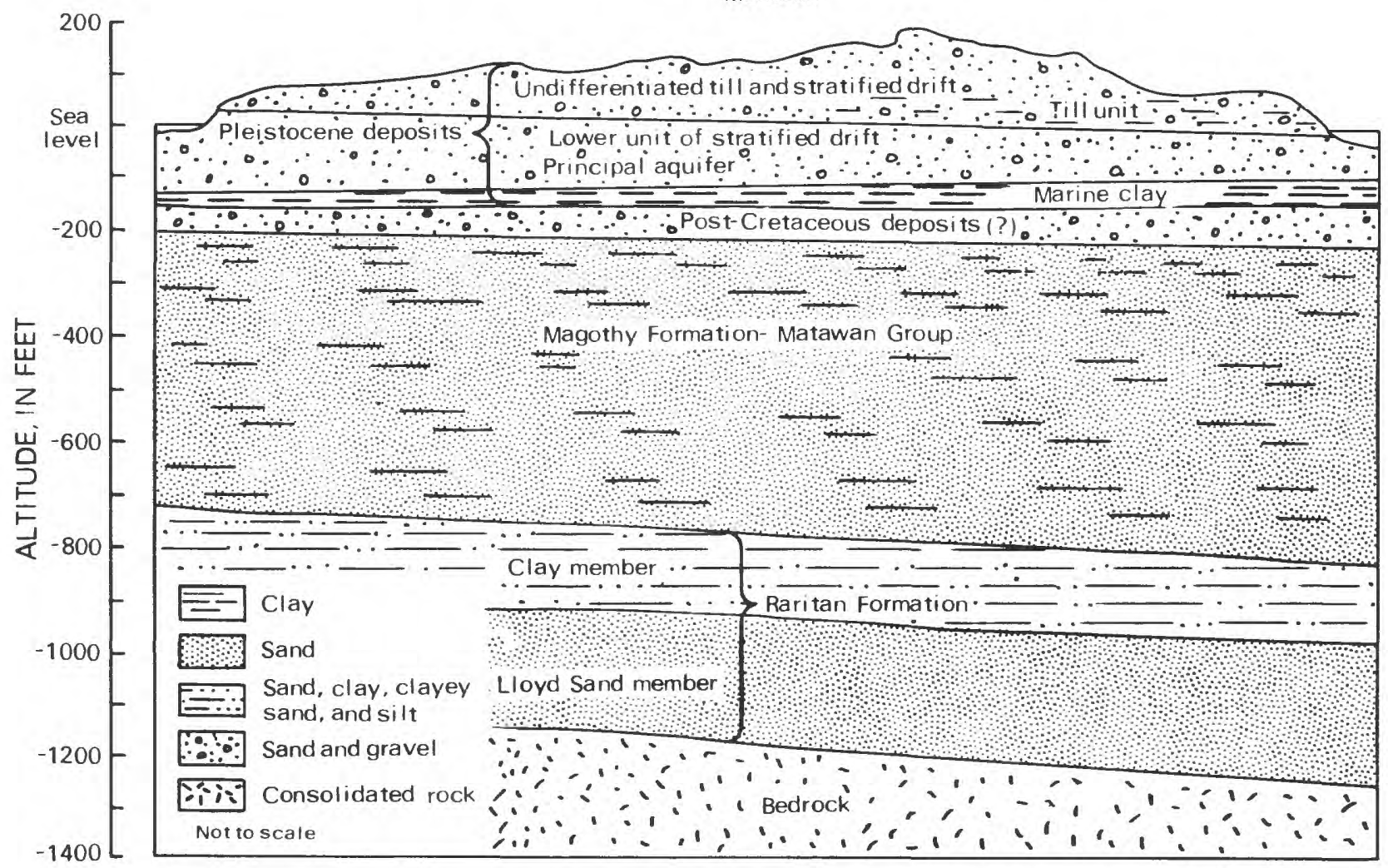

Figure 3.--Generalized geologic section of the Montauk area.

\section{Bedrock and Cretaceous Deposits}

The only freshwater in the Montauk area is in the shallow unconsolidated Pleistocene deposits; therefore, few wells or test holes have been drilled to deep Cretaceous deposits or bedrock. Although no wells in the Montauk area have penetrated bedrock or the Raritan Formation, some inferences on altitude and areal extent can be drawn from deep test-hole data obtained on the North Fork and elsewhere on the south fork (Jensen and Soren, 1974, and Nemickas and Koszalka, 1982). 
Table 1.--Summary of geologic and hydrogeologic units in the Montauk area, Suffolk County, N.Y.

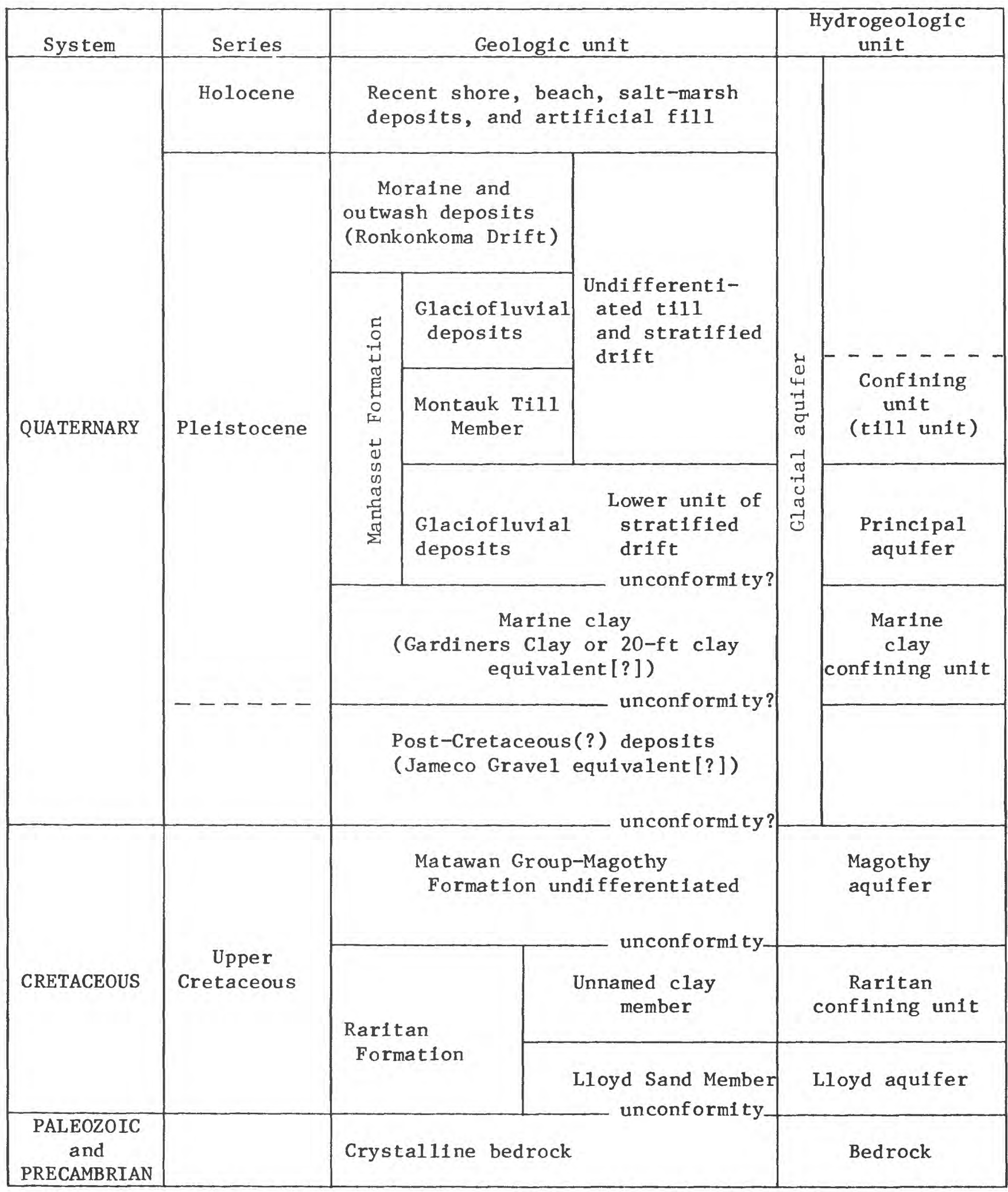


The basement complex of Precambrian and Paleozoic gneiss and schist is estimated to lie at depths ranging from a little less than $1,100 \mathrm{ft}$ below sea level in the northeastern part of the Montauk area to about $1,300 \mathrm{ft}$ in the southwestern part. The surface of the overlying Lloyd sand member of the Raritan Formation is estimated to range from about 800 to $1,000 \mathrm{ft}$ below sea leve1, and the surface of the unnamed clay member is estimated to range from slightly more than $700 \mathrm{ft}$ to about $850 \mathrm{ft}$ below sea level.

Three deep wells drilled in the Montauk area have reached the Magothy Formation, but none have penetrated its full thickness. These are well S60125, northeast of the village of Montauk, and wells S31735 and S73083 in Hither Hills (pl. 1). (Well numbers are assigned sequentially by New York State; the prefix "S" designates Suffolk County.) The surface of the Magothy Formation-Matawan Group (equivalent to the surface of the Magothy aquifer) is between 200 and $218 \mathrm{ft}$ below sea level in each of these wells. The Magothy Formation-Matawan Group consists of beds of poorly sorted quartzose sand interbedded with silt and clay and commonly contains pyrite, lignite, and iron oxide concretions.

Two wells in the Montauk area, S61124 and S70261 (pl. 1), were drilled to depths much greater than that at which the Magothy Formation would be expected, but no Magothy sediments were recognized. Instead, a thick sequence of glacially varved silts and clays ranging from 178 to $333 \mathrm{ft}$ below sea level in well S61124 and from 212 to $364 \mathrm{ft}$ below sea level in we11 S70261 (p1. 1) was encountered. This indicates that at least two deep erosional channels were cut into the Magothy Formation and later filled with post-Cretaceous(?) or Pleistocene material. The areal extent of these channels is unknown, however.

\section{Post-Cretaceous(?) and Pleistocene Deposits}

The Pleistocene deposits of Long Island are the result of alternating advancement and retreat of several ice sheets during the Pleistocene Epoch. A detailed account of Pleistocene geology can be found in Fuller (1914).

Glacial deposits are divided into two broad categories--till (unstratified drift) and stratified drift--according to mode of deposition. Till is a poorly sorted mixture of boulders, gravel, sand, silt, and clay that was deposited directly by melting glacial ice; stratified drift consists of some or all of these materials but was sorted into discrete beds of uniform particle size, ranging from gravel to clay, by the winnowing action of flowing meltwater. Stratified drift in the Montauk area occurs as glaciofluvial sand and gravel, glaciolacustrine sand and clay, and glaciomarine silt and clay. The moraine deposits of the Ronkonkoma Drift, which forms the hills of the terminal moraine, are principally till.

The post-Cretaceous(?) and Pleistocene deposits in the Montauk area consist of the following units: (1) the post-Cretaceous(?) deposits, (2) a marine clay unit of glaciomarine(?) deposition, (3) the Manhasset Formation, which consists of glaciofluvial deposits with the interbedded Montauk Till Member, and (4) moraine (mainly till) and outwash deposits of the Ronkonkoma Drift. Because it is difficult to recognize discrete units of till and outwash in well logs and outcrops, the U.S. Geological Survey has, in the 
past, used the name "Pleistocene deposits" for all glacial deposits of postGardiners Clay age. Lacking a definitive Gardiners Clay from which to draw a correlation boundary, Perlmutter and Deluca (1963) divided the Pleistocene deposits into a lower unit of stratified drift and an upper unit of undifferentiated till and stratified drift. Presumably the lower unit of stratified drift is equivalent to the glaciofluvial deposits of the Manhasset Formation beneath the Montauk Till Member; the upper unit of undifferentiated till and stratified drift is composed of the Montauk Till Member and the overlying glaciofluvial deposits of the Manhasset Formation and the Ronkonkoma Drift.

\section{Post-Cretaceous(?) Deposits}

In some areas of Montauk, a sand and gravel unit, possibly of postCretaceous age, lies between the Magothy Formation-Matawan Group and the overlying marine clay unit (fig. 3). This unit appears to be a glaciofluvial deposit consisting of very fine to very coarse sand that ranges from light brown to brown and is similar to Pleistocene glacial material. In some places, however, the unit consists of very fine to fine gray sand closely resembling the underlying Magothy Formation-Matawan Group. The post-Cretaceous(?) unit may be equivalent in age to Jameco Gravel. (The Jameco Gravel in western Long Island is the lowermost unit of Pleistocene age on Long Island.)

Six wells in the Montauk area have been drilled deep enough to reach this unit. We11s S31735, S60125, and S73053 fully penetrate the unit; wells S70255, S70258, and S70261 partially penetrate it (p1s. I and 2). The upper surface of the post-Cretaceous(?) unit is between $140 \mathrm{ft}$ and $150 \mathrm{ft}$ below sea level in these we11s, and the unit has a maximum thickness of $70 \mathrm{ft}$.

In most places, the freshwater/saline water interface is above this unit, but small freshwater lenses locally occur within it. A thin lens of freshwater was found in the upper 15 to $20 \mathrm{ft}$ of the post-Cretaceous(?) deposits at we11 S73083, but no other freshwater was encountered within this unit.

\section{Marine Clay}

Overlying the post-Cretaceous(?) unit is a marine clay unit ranging from fine silt to hard gray-green clay and containing shell fragments. The major minerals found in X-ray diffraction analysis were chlorite, illite, kaolinite, and occasionally vermiculite (Dennis Radcliff, Hofstra University, written commun., 1982). Twelve deep test holes in the Montauk area have either partially or fully penetrated the marine clay unit. The upper surface of the clay unit ( $\mathrm{fig} .4$ ) is gently undulating and ranges from slightly less than $100 \mathrm{ft}$ below sea level in wel1 $\mathrm{S} 73083$ to more than $145 \mathrm{ft}$ below sea level in well s70261. The thickness of the clay ranges from $15 \mathrm{ft}$ at well $\mathrm{S} 60125$ to as much as $43 \mathrm{ft}$ at $\mathrm{S} 70261$.

The marine clay unit correlates with a similar marine-clay unit reported by Soren (1978) to underlie Shelter Island to the west of Montauk (fig. 1) and with marine clays reported by Nemickas and Koszalka (1982) as Gardiners(?) Clay at the north and south shores of the south fork near the SouthamptonEast Hampton town boundary (fig. 1). The reported upper surface of the marine 
clay unit ranges from somewhat less than $40 \mathrm{ft}$ below sea level on the south fork to about $100 \mathrm{ft}$ below sea level on Shelter Island (fig. l). This unit is similar in thickness, composition, and altitude to the marine clay in the Montauk area; thus, the two are considered equivalent units.

Whether the marine clay correlates with the Gardiners Clay is uncertain. The marine clay may correlate with the "20-foot" clay of western Long Island or may correlate with neither unit.

\section{Lower Unit of Stratified Drift}

The lower unit of stratifled drift of the Manhasset Formation (fig. 3 ) is composed of fine to coarse cross-bedded sand and gravel with thin lenses of silt and clay. Core samples from this unit have been reported to consist chiefly of quartz with miscellaneous grains of granite, gneiss, schist, and

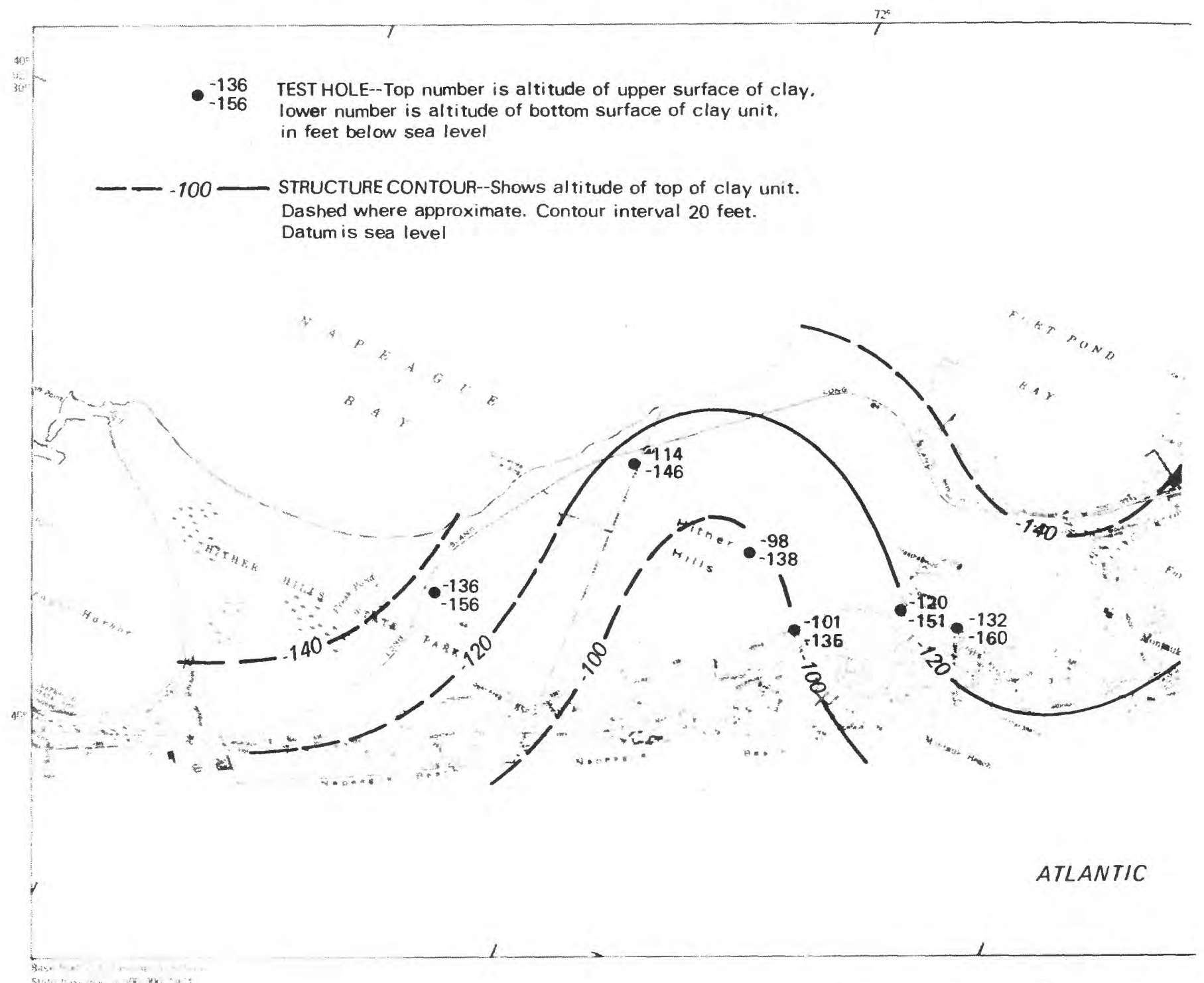

Figure 4.--Altitude of the 
the minerals garnet, biotite, chlorite, and hornblende (Perlmutter and DeLuca, 1963). Differentiation between the outwash, moraine, and till deposits is not always possible from drillers' logs because they are nearly identical in 1ithologic composition. However, moraine and till deposits may contain a greater percentage of fine-grained material than stratified drift and hence can be differentiated from outwash in natural gamma-ray geophysical logs.

The lower unit of stratified drift is the only major freshwater-bearing unit in the Montauk area and is therefore referred to as the principal aquifer. It was first described by Perlmutter and DeLuca (1963). The aquifer ranges in thickness from about $85 \mathrm{ft}$ in the central part of the Hither Hills area to as much as $130 \mathrm{ft}$ near Montauk Point. In areas where overlying till or unstratified drift are absent, the unit is characterized by stratified outwash up to land surface. In these places the aquifer extends from the marine clay to the water table--a thickness not exceeding $130 \mathrm{ft}$.

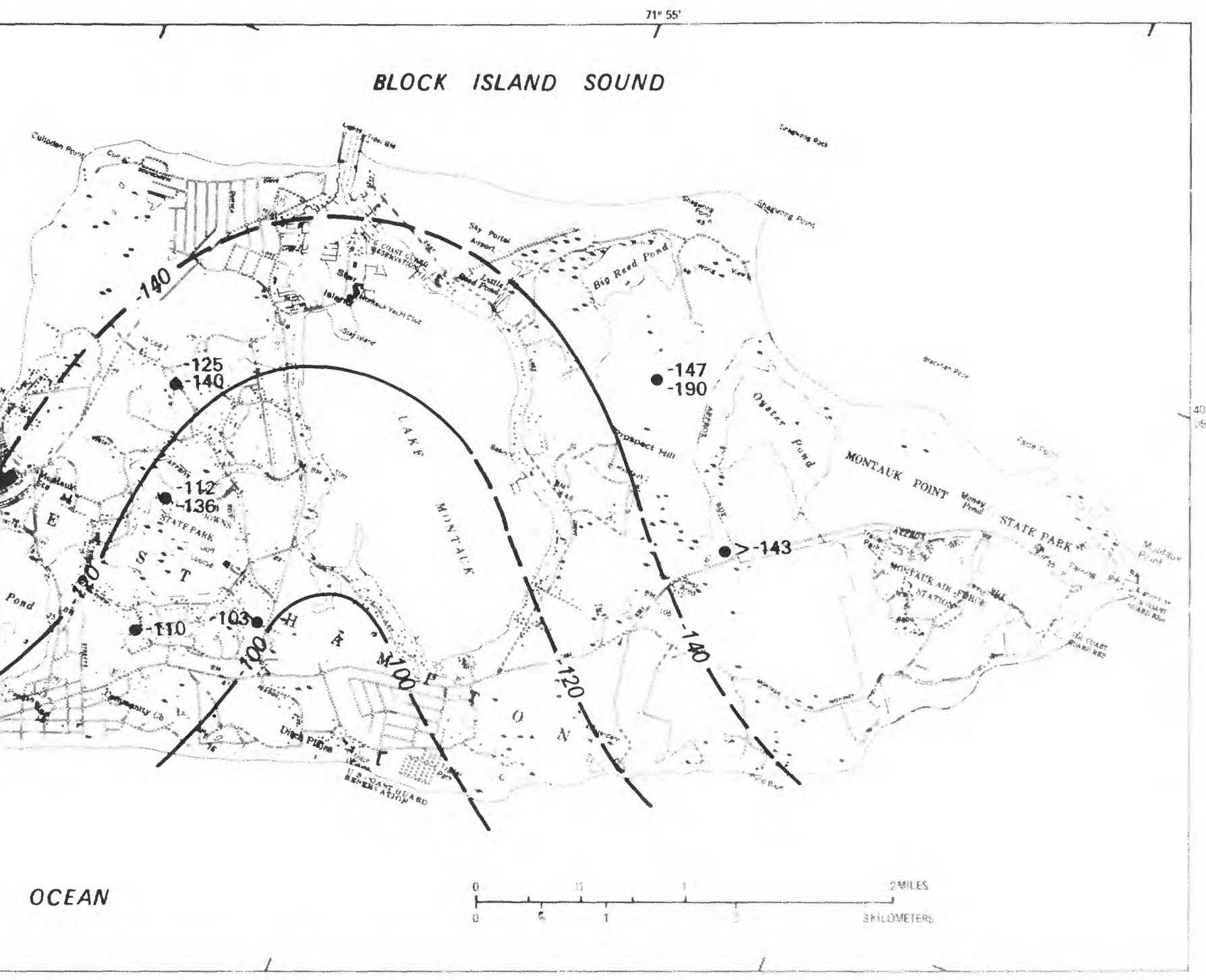

top of the marine clay unit. 


\section{Undifferentiated Deposits of Till and Stratified Drift}

Overlying the lower unit of stratified drift (the principal aquifer) is an undifferentiated unit (including the upper part of the Manhasset Formation) composed of tightly interbedded layers of till, stratified drift, and moraine deposits (hereafter referred to as the "till unit"). In the area east of Lake Montauk, the lower 20 to $40 \mathrm{ft}$ of this unit consists of interbedded gray and brown clay, laminated green and gray silt and clay, and some thin lenses of fine brown sand (Perlmutter and Deluca, 1963). The middle part of the unit consists of gray and brown compact clayey and gravelly till (Montauk Till Member), occasionally grading laterally into fine-grained stratified drift. Overlying the compact till is a generally stratified drift 0 to $30 \mathrm{ft}$ thick and composed mostly of lenses of brown and gray silt, fine to medium sand, and clayey sand. The uppermost part of the unit is generally a loose brown clay till (morainal deposits) 5 to $20 \mathrm{ft}$ thick. Till within the unit of undifferentiated deposits is discontinuous and appears to be displaced in some areas (Nieter and others, 1975). The compact till ranges from $10 \mathrm{ft}$ to more than $50 \mathrm{ft}$ thick in some places.

Thickness of the till varies widely in the Montauk area; geophysical logs indicate thick deposits of till and unstratified drift in some wells and none in other wells only a few hundred feet away. The irregular distribution of

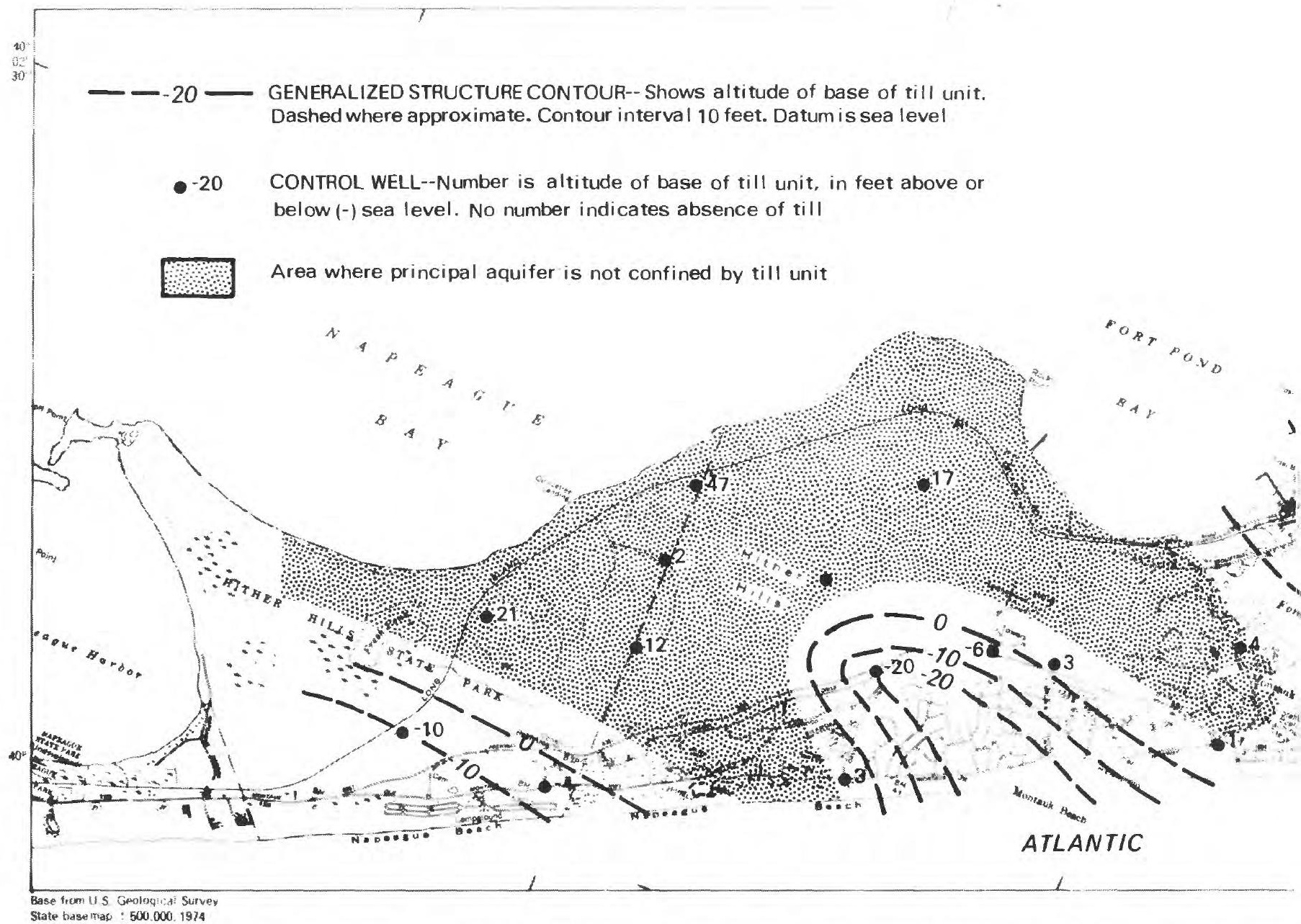

Figure 5.--Altitude of the base of the undifferentiated deposits of till and 


\section{HYDROLOGY}

Al1 freshwater in the Montauk area originates as local precipitation. Water falling on the land efther infiltrates the land surface, becomes overland runoff, or rapidly returns to the atmosphere through evapotranspiration. Of the water that infiltrates the soil, some is eventually returned to the atmosphere through evaporation and transpiration, some moves laterally to stream channels and becomes streamflow, and the remainder moves into the deeper units and eventually discharges to the surrounding saltwater bodies.

\section{Ground-Water System Boundaries}

The rate of water movement into, through, and out of the ground-water flow system is dependent upon aquifer characteristics, hydraulic gradients, and the shape and dimensions of the aquifer system. The geometry of the aquifer system is dependent upon the aquifer boundaries. An evaluation of ground-water movement and system responses to stress requires a knowledge of the boundary conditions of the system and how they affect ground-water movement.

The Montauk ground-water flow system has three types of boundaries--the freshwater-saltwater interface beneath and surrounding the Montauk peninsula, the confining units within the fresh ground-water flow field, and the freemoving water-table surface.

\section{Freshwater/Saltwater Interface}

Beneath and surrounding the Montauk peninsula is an interface between freshwater and the surrounding saltwater. This interface, which results from differences in fluid density, is not a sharp boundary such as would form between two immiscible fluids; rather it is a zone of diffusion, as depicted in a generalized manner in figure 6. Lata collected during test drilling in 1980-81 suggest that the zone of diffusion in the Montauk area is relatively thin, as indicated by a chloride concentration of 20 to $40 \mathrm{mg} / \mathrm{L}$ on the freshwater side, which increases by more than an order of magnitude within 20 $\mathrm{ft}$. The position of this boundary is not fixed but depends upon a balance of fluid pressures on both sides of the interface. An increase in ground-water withdrawals (or a decline in head for any other reason in the freshwater system) will cause landward or upward movement of the saltwater interface. This interface on the Montauk peninsula, as on any island, forms the lower and lateral boundary of the freshwater system.

Water in the principal aquifer moves from areas of higher hydraulic head (generally the central region of the peninsula) to areas of lower hydraulic head (near the shore). Beyond the shores, water from the aquifer discharges outward and upward through ocean and bay floors into the saltwater. This outward movement of freshwater prevents the surrounding saline water from moving into the aquifer system. The rate of discharge to the ocean is controlled by the freshwater head, the aquifer permeability, the size of the ocean- or bay-floor area through which discharge occurs, and the ocean depth above the discharge zone. Little work has been done to define the distance offshore to which the discharge zone extends, but it may be no more than a few hundred feet. 


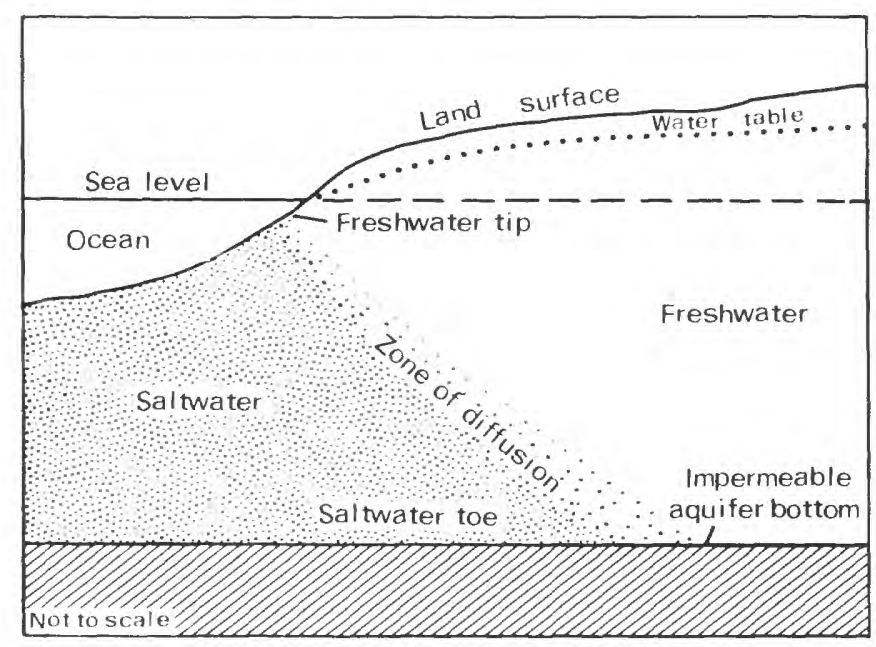

\section{Figure 6 .}

Generalized hydrogeologic

section showing the

interface between fresh-

water and saltwater in a

coastal aquifer. The

denser saltwater forms a

toe that extends into

the aquifer laterally

beneath the freshwater.

\section{Confining Units}

The fresh ground-water flow field in the Montauk area contains two major confining beds--the marine clay unit (fig. 4) at the base of the principal aquifer and the till unit, which forms the upper boundary of much of the aquifer (fig. 5).

Marine clay unit.--This unit has low hydraulic conductivity and thus has a significant effect on flow patterns in the Montauk area. A significant head loss occurs vertically through the unit, and the resulting head is insufficient to maintain freshwater in or beneath the unit. For this reason, the freshwater/saltwater interface beneath some of the Montauk area lies at the surface of the marine clay unit or within it (p1.2). Even where the interface is beneath the clay, long-term supplies of freshwater cannot be obtained because the clay inhibits the infiltration of freshwater from above. Freshwater/saline-water relationships and the hydrologic effects of the clay are discussed in more detail further on. The marine clay unit can be considered an impermeable bottom boundary of the freshwater flow system wherever the saltwater interface is within or beneath it.

Till unit.--The aquifer is confined in some places by the overlying till unit. A schematic diagram of the relationship between the till unit and the potentiometric surface is shown in figure 7. Wherever the potentiometric surface of the aquifer is above the bottom of the till unit, such as the shaded area in figure 7 , the aquifer is confined; wherever this unit is absent or above the potentiometric surface, the aquifer is unconfined and responds as a water-table aquifer with a moving free surface.

\section{Occurrence of Ground Water}

Precipitation that seeps into the soil and is not lost through evapotranspiration percolates downward into the till unit (where present) and to the water table, the main zone of saturation. Some water moves laterally in the till unit and discharges near the shore; the rest continues to move downward to the aquifer. 


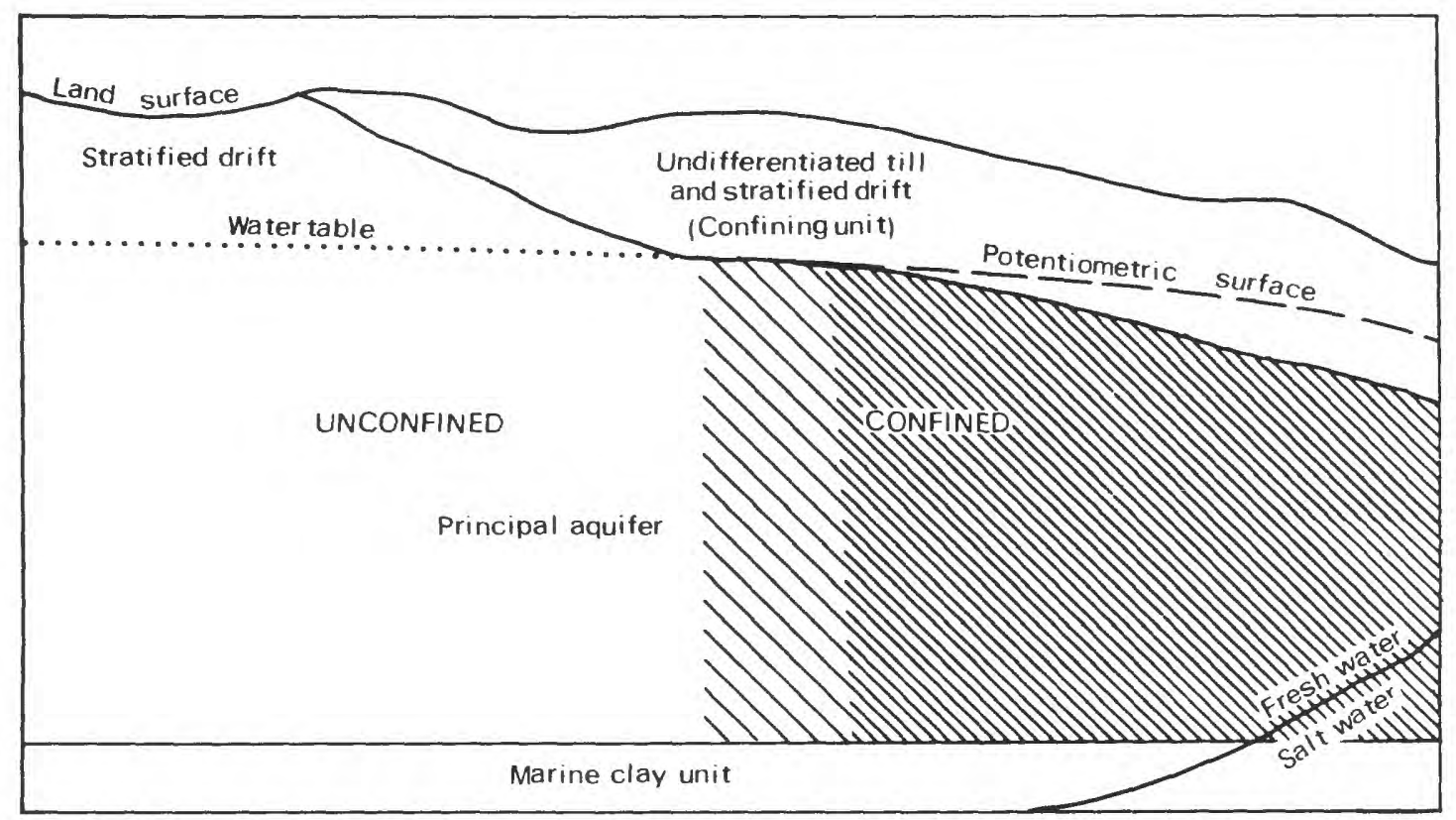

Figure 7.--Generalized hydrogeologic section of aquifer showing an area confined by the till unit and an area under unconfined (water-table) conditions.

\section{Water in the Till Unit}

Some water in the till unit may occur locally beneath the water table, in contact with the main body of freshwater in the principal aquifer, but most occurs in minor perched water-bearing zones above the main water table. Downward movement of water through the till unit is locally impeded by lenses of clay, silt, and till.

The till unit cannot yield substantial amounts of water to wells because of poor sorting and high clay and silt content. Despite the numerous lenses of perched water, the till unit acts mainly as a confining bed that inhibits recharge to the underlying aquifer.

Most recharge to the aquifer occurs through the overlying till unit, but only where head gradients are sufficiently high. For example, the till unit in the central Montauk area between Fort Pond and Lake Montauk contains high water levels that create large gradients toward the underlying principal aquifer.

Comparison of water levels from two wells at the same location but with different screened zones can indicate the gradients necessary to recharge the principal aquifer. We11 S70620, 1/2 mi west of Lake Montauk, is screened in the till unit at about sea level, and well s70258, $50 \mathrm{ft}$ awa;, is screened in the principal aquifer at about $80 \mathrm{ft}$ below sea level. The water level in the till unit is more than $35 \mathrm{ft}$ above sea leve1, whereas that in the principal aquifer is generally only 3 to $4 \mathrm{ft}$, a gradient of about $0.39 \mathrm{ft} / \mathrm{ft}$. A comparison of water levels at this site is shown in hydrographs in figure 8. 

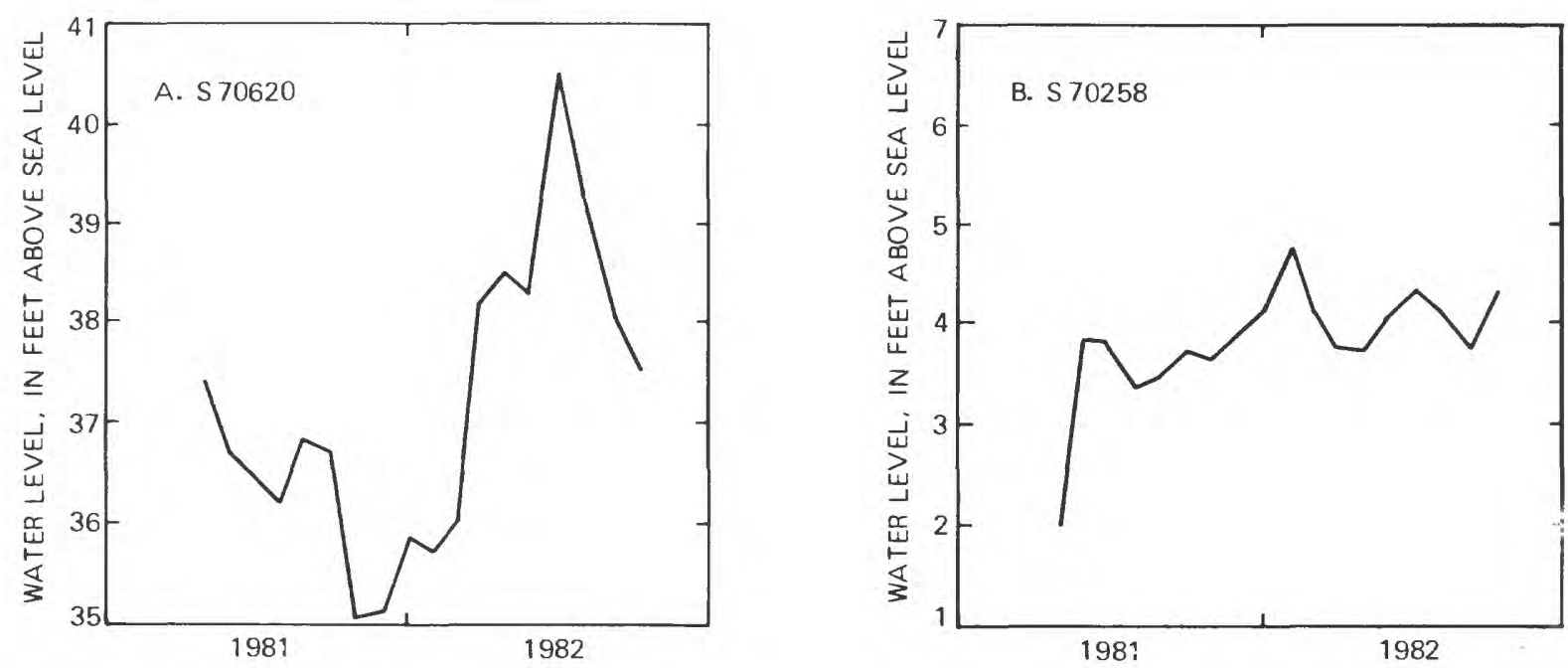

Figure 8.-Comparison of water levels in two wells approximately $50 \mathrm{ft}$ apart in the central Montauk area: A. Well S70620, screened in till unit. B. Well S70258, screened in underlying principal aquifer. (Well locations are shown in pl. 1.)

The till unit inhibits recharge to the principal aquifer not only by retarding downward movement of ground water as explained above, but also by increasing surface runoff. Infiltration in areas where the till unit is exposed at or near land surface occurs less easily than in areas of stratified drift, and some water moves laterally along the till unit and discharges as seepage into stream channels. This reduces the overall volume of precipitation available to recharge the principal aquifer.

The amount of water recharging the principal aquifer is difficult to estimate. Although recharge is inhibited in places, the till unit is discontinuous, and water may move laterally around the confining layers. Also, high vertical gradients in the confining beds maintain downward flow. These two factors suggest that a large volume of water reaches the principal aquifer despite the low permeability of the overlying deposits.

\section{Water in the Principal Aquifer}

The main sources of freshwater in the Montauk area are the deposits of stratified drift that form the principal aquifer. Most wells supplying water to the Montauk area tap this aquifer. Freshwater enters the aquifer through the till unit from above and, under undisturbed conditions, moves laterally toward the shore, where it seeps out to the surrounding saltwater bodies, as shown in figure 6 . The aquifer is bounded at its base by the lower confining unit or the saltwater interface, whichever is at higher altitude. Generally, the freshwater body becomes thinner near the shore, and, during periods of heavy pumping near the shore, the saltwater toe beneath the freshwater lens (fig. 6) can be drawn into the wells. 
Where the till unit is present, the principal aquifer is under artesian pressure; where the till unit is absent or above the aquifer's potentiometric surface, the aquifer is under water-table conditions. Potentiometric heads in the aquifer are higher in the central part of the three major landmasses on the Montauk Peninsula than near the shores; however, the artesian pressure is not sufficient to cause wells to flow.

A potentiometric-surface map of the principal aquifer (a map showing the levels to which water will rise in tightly cased wells tapping the aquifer) (fig. 9) was constructed from data collected from 31 wells during March and April 1982 and from maps by Perlmutter and DeLuca (1963) and Nemickas and Koszalka (1982). Maximum water levels of just under $4 \mathrm{ft}$ above sea level were measured in March-April 1982 in the central area of Hither Hills and in the central region of Montauk.

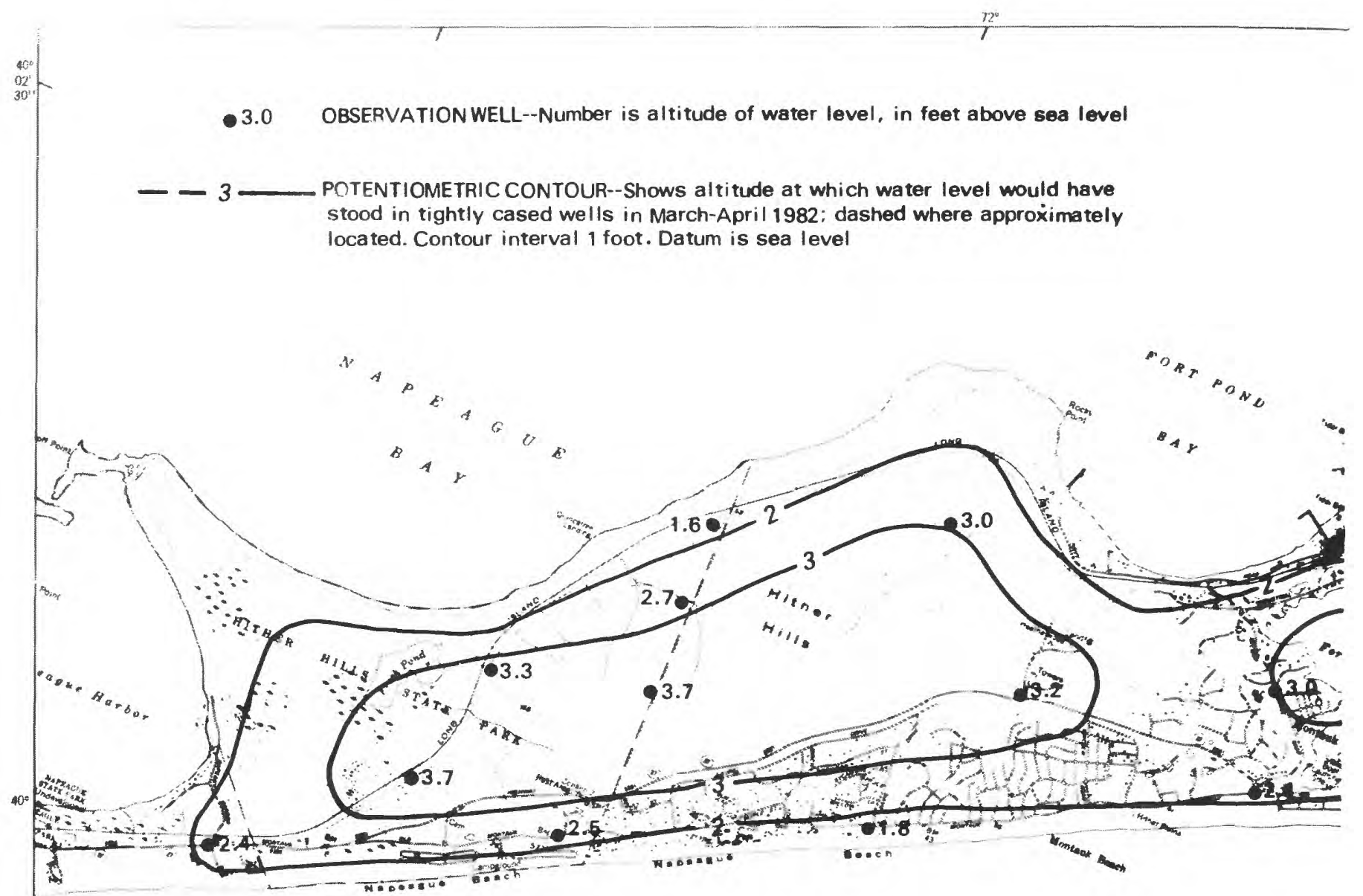

ATLANTIC 
Water-level contours in several areas where data were lacking could only be inferred. For example, parts of Hither Hills and the Prospect Hill area were inaccessible because of thick woods and dense underbrush, which prevented well drilling. Where a few wells were drilled in the Prospect Hill area, water levels were anomalously high--as much as $45 \mathrm{ft}$ above sea level (fig. 9). These high water levels are attributed to the low permeability of some thick glacial clays that occur from about $20 \mathrm{ft}$ to more than $400 \mathrm{ft}$ below sea level, which retard the vertical movement of ground water.

The general direction of freshwater movement is from the three central high areas on the peninsula radially outward to the shores, where it discharges to tidewater. Horizontal movement is perpendicular to the equipotential contours. The horizontal gradient in the Montauk area is from 2 to $4 \mathrm{ft} / \mathrm{mi}$ regionally but becomes much greater near pumping wells.

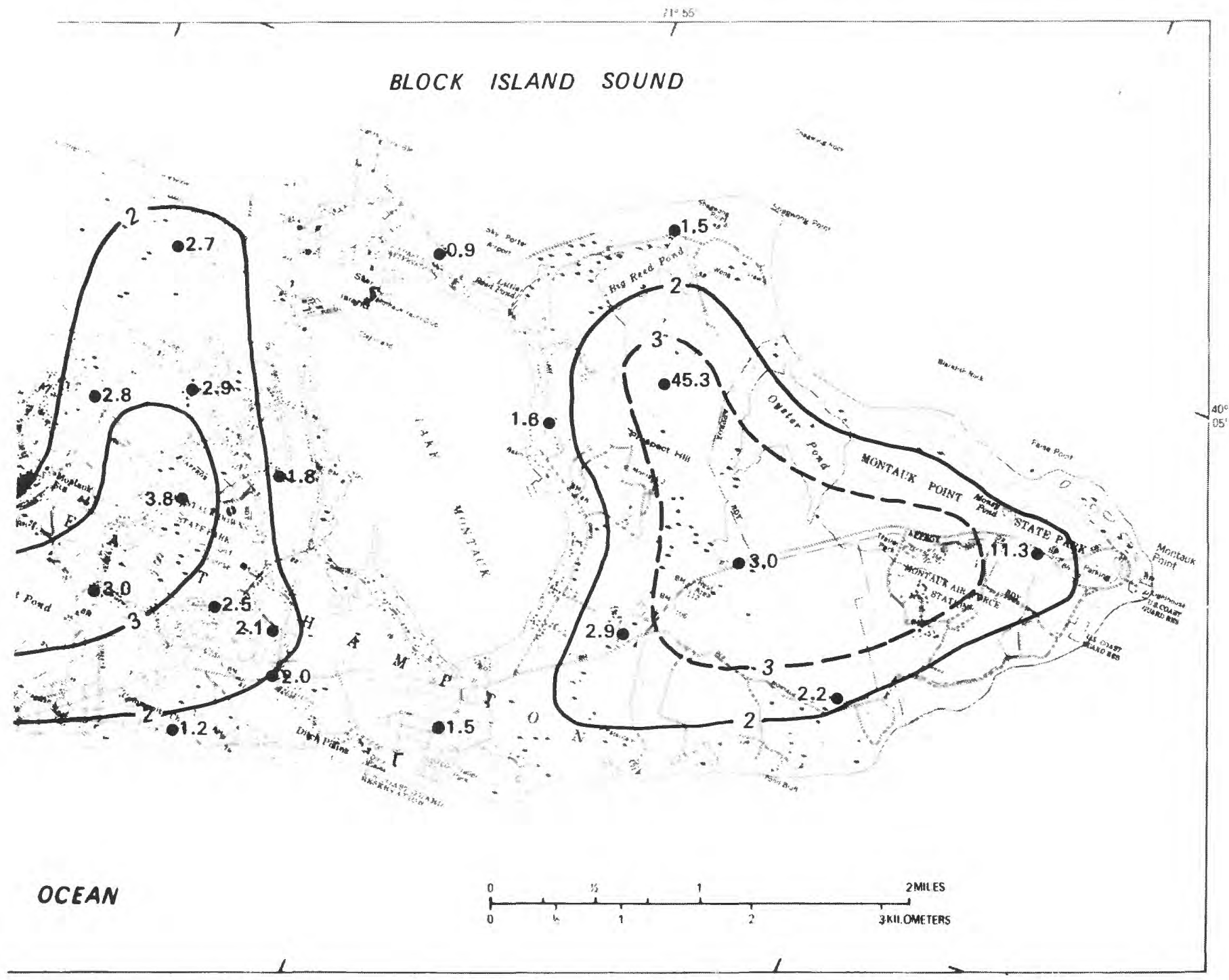

principal aquifer during March-April 1982. 
Fluctuations in water levels are the result of changes in the balance between recharge and discharge in the aquifer. Large fluctuations occur seasonally in response to sharp changes in demand, and long-term trends result from changing climatic conditions and increases in ground-water pumpage. Also, the influences of barometric pressure and ocean tides cause minor fluctuations of water levels in the principal aquifer. Fluctuations in water levels are reflected in the hydrographs of wells screened in both the principal aquifer and the till deposits shown in figures 8 and 10 and in the water-level data in table 11 (at end of report). Seasonal fluctuations in the principal aquifer are less than $2 \mathrm{ft}$ in most places; daily fluctuations due to tidal effects vary in response to tidal intensity and with distance from the shore. Daily fluctuations measured at well $\$ 72419$ ranged from 0.3 to $0.8 \mathrm{ft}$.

The earliest data on water levels in the principal aquifer were collected during the early 1960's (Perlmutter and DeLuca, 1963); no continuous data were collected thereafter until 1974, when regular measurements were begun at a few scattered we1ls. A comparison of 1974-80 water levels (fig. 10) with those reported by Perlmutter and DeLuca (1963, p1.1) indicates no significant long-term trends.

\section{Surface-Water Features}

Surface-water features of the Montauk area include lakes, ponds, sma11 streams, and numerous sma11 marshy areas. The major lakes and ponds of the area are Fresh Pond, Fort Pond, Big Reed Pond, Little Reed Pond, and Lake Montauk, a tide bay freely connected with the ocean (fig. 2). Seven major streams drain the Montauk area--the outlet from Little Reed Pond, which discharges to Lake Montauk, and six unnamed streams. Three unnamed streams discharge into Lake Montauk, one discharges into the Atlantic Ocean, and two are internal drainage and discharge into Oyster Pond.

\section{Marshes}

The smal1 marshes that are present in minor topographic depressions receive freshwater both from precipitation and ground-water discharge. Some of these marshes are at relatively high altitudes--more than $20 \mathrm{ft}$ above sea level and far above the potentiometric surface of the principal aquifer. These marshes contain water most of the year because they are underlain by deposits of low permeability such as silt and till, which inhibit outflow. Although small amounts of water leave these marshes by percolating through the silt and till to the deeper aquifer, most water leaves by evapotranspiration.

\section{Streams}

Streams in the Montauk area occupy drainage charnels that are not well developed. Overland runof $f$ that forms during and immediately after storms (direct runoff) flows into channels and gullies and from there to surrounding saltwater bodies or to lakes, ponds, and marshes.

Compared to other parts of Long Island, the Montauk area has greater relief, lower permeability of surface deposits (where till and unstratified drift are present), and higher humidity as a result of being surrounded by the ocean; thus, direct runoff in the Montauk area probably forms a greater 

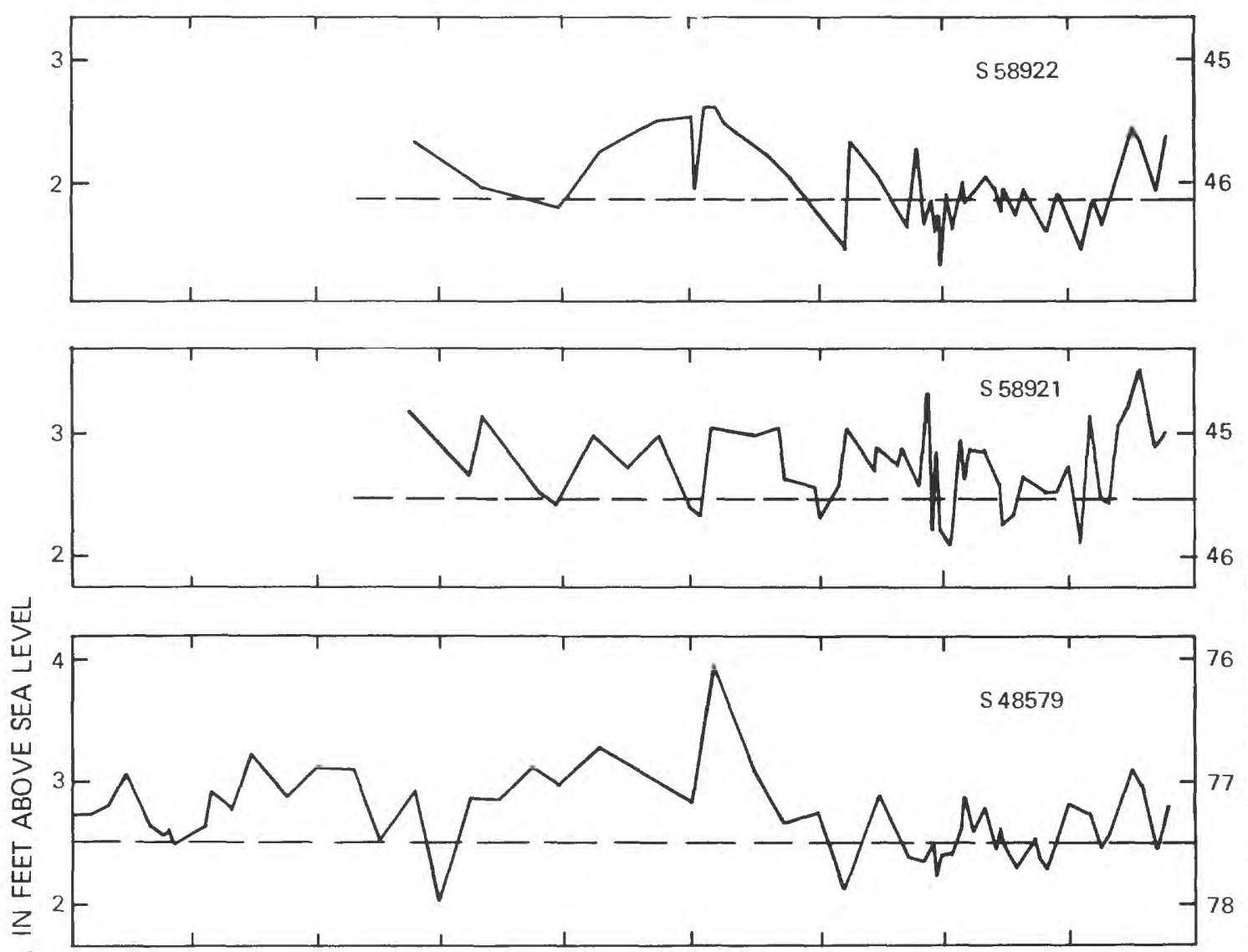

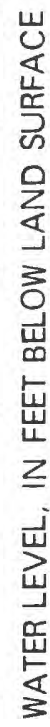
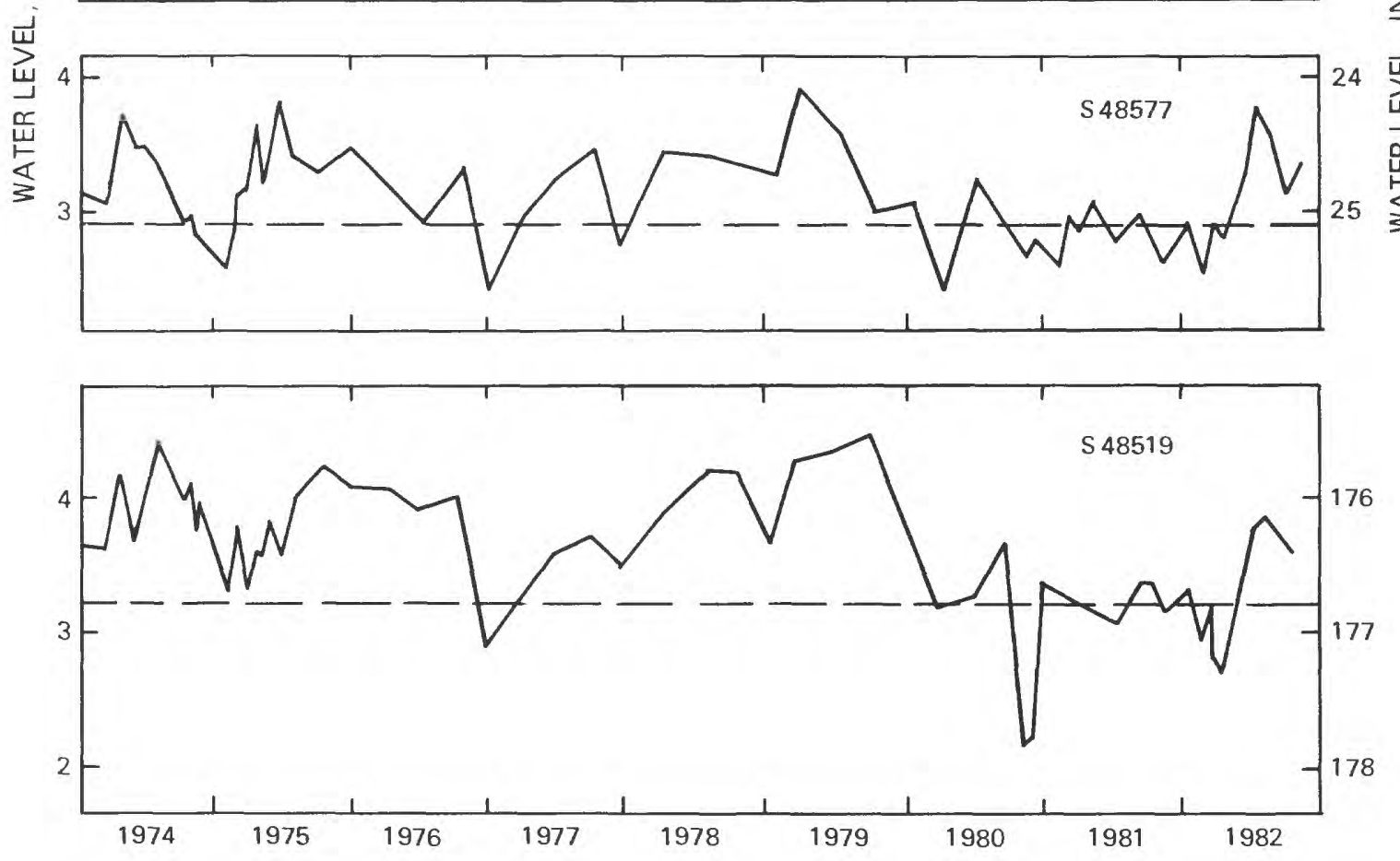

Figure 10.-Hydrographs of wells screened in the principal aquifer, 1974-82. Dashed line indicates approximate water level in March-April 1982. (Well locations are shown in pl. 1.) 
percentage of total streamflow than elsewhere on Long Island. Unlike most of Long Island's streams further west, streamflow in the Montauk area remains high for several days after a storm because the precipitation, unable to percolate rapidly downward, moves laterally through the soil and discharges to stream channels.

Table 2.--Discharge of selected streams on the Montauk peninsula, 1980-82. [Locations are shown on pl. 1.]

\begin{tabular}{|c|c|c|c|c|}
\hline $\begin{array}{l}\text { Station } \\
\text { number }{ }^{1}\end{array}$ & Station name & $\begin{array}{l}\text { Latitude/ } \\
\text { Longitude }\end{array}$ & Date & $\begin{array}{r}\text { Discharge } \\
\left(\mathrm{ft}^{3} / \mathrm{s}\right)\end{array}$ \\
\hline 01304680 & $\begin{array}{l}\text { Lake Montauk tributary } \\
\text { near Ditch Plains }\end{array}$ & $\begin{aligned} 41^{\circ} 03^{\prime} 23^{\prime \prime} & 071^{\circ} 55^{\prime} 53^{\prime \prime}\end{aligned}$ & $\begin{array}{r}12-19-80 \\
4-16-81 \\
7-1-81 \\
10-8-81 \\
4-16-82 \\
7-15-82 \\
10-19-82\end{array}$ & $\begin{array}{c}0.01 \\
.10 \\
.01 \\
\text { Dry } \\
.19 \\
.29 \\
.00\end{array}$ \\
\hline 01304683 & $\begin{array}{l}\text { Lake Montauk tributary } 2 \\
\text { at Ditch Plains }\end{array}$ & 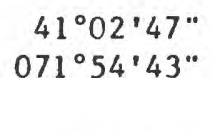 & $\begin{array}{r}4-16-82 \\
7-15-82 \\
10-19-82\end{array}$ & $\begin{array}{l}.21 \\
\text { Dry } \\
.00\end{array}$ \\
\hline 01304684 & $\begin{array}{l}\text { Lake Montauk tributary } 3 \\
\text { at Ditch Plains }\end{array}$ & $\begin{aligned} 41^{\circ} 02 ' 57^{\prime \prime} \\
071^{\circ} 54^{\prime} 27^{\prime \prime}\end{aligned}$ & $\begin{array}{r}4-16-81 \\
7-1-81 \\
10-8-81 \\
4-16-82 \\
7-15-82 \\
10-19-82\end{array}$ & $\begin{array}{l}.15 \\
\text { Dry } \\
\text { Dry } \\
.22 \\
\text { Dry } \\
\text { Dry }\end{array}$ \\
\hline 01304686 & $\begin{array}{c}\text { Oyster Pond tributary } \\
\text { near Montauk Point }\end{array}$ & $\begin{array}{r}41^{\circ} 03^{\prime} 54^{\prime \prime} \\
071^{\circ} 53^{\prime} 14^{\prime \prime}\end{array}$ & $\begin{array}{r}12-19-80 \\
4-16-81 \\
7-1-81 \\
10-8-81 \\
4-16-82 \\
7-15-82 \\
10-19-82\end{array}$ & $\begin{array}{l}.08 \\
.75 \\
.16 \\
.00 \\
.61 \\
.24 \\
.00\end{array}$ \\
\hline 01304689 & $\begin{array}{c}\text { Oyster Pond tributary } 2 \\
\text { near Montauk Point }\end{array}$ & $\begin{array}{l}41^{\circ} 03^{\prime} 58^{\prime \prime} \\
071^{\circ} 53^{\prime} 06^{\prime \prime}\end{array}$ & $\begin{array}{r}12-19-80 \\
4-16-81 \\
7-1-81 \\
10-8-81 \\
4-16-82 \\
7-15-82 \\
10-19-82\end{array}$ & $\begin{array}{l}.08 \\
.15 \\
.06 \\
.00 \\
.27 \\
.43 \\
.00\end{array}$ \\
\hline 01304690 & $\begin{array}{l}\text { Unnamed tributary to } \\
\text { Atlantic Ocean near } \\
\text { Montauk Point }\end{array}$ & $\begin{array}{r}41^{\circ} 03^{\prime} 46^{\prime \prime} \\
071^{\circ} 51^{\prime} 57^{\prime \prime}\end{array}$ & $\begin{array}{r}12-19-80 \\
7-1-81 \\
10-8-81 \\
7-15-82 \\
10-19-82\end{array}$ & $\begin{array}{l}.02 \\
.92 \\
.001 \mathrm{e} \\
.17 \\
.015 \mathrm{e}\end{array}$ \\
\hline
\end{tabular}

1 A unique station identification number assigned by the U.S. Geological Survey to each gaging location.

e = estimated discharge 
The Montauk area has only a few streams capable of sustaining flow during dry-weather periods. These streams are fed by ground-water seepage from locally high water tables or perched water bodies in the till unit. In summer and fall, when the water table is lowest and evapotranspiration highest, most of the streams become dry.

Discharge of six unnamed streams was measured periodically during this study (table 2); their locations are shown in plate 1 . The only stream that maintains continuous discharge that was not measured was the outlet from Little Reed Pond ( 1.1 ), which is tidal. (Accurate discharge measurements at this site would be impossible because the volume of tidewater that entered the pond during the previous high tide cannot be estimated.)

Streamflow at two of the stations--01304686 and 01304689 near the northeastern tip of the area (pl. 1)--does not discharge to tidewater but to Oyster Pond. Thus, discharge from these streams is not necessarily a net outflow from the ground-water system; rather, it feeds Oyster Pond, where its fate is determined by the water budget for the pond.

\section{Ponds}

A11 major ponds in the Montauk area are fed by ground water flowing from areas of higher head in the till unit to areas of lower head and by overland runoff; Oyster Pond is also fed by streamflow. The water level in the ponds reflects the water level in the till unit and not the potentiometric surface of the underlying principal aquifer because the confining till unit inhibits vertical ground-water movement. The relationship between the water level in the ponds and the potentiometric surface of the principal aquifer varies throughout the year; water levels in the pond are higher than the potentiometric surface of the principal aquifer during winter and spring, when precipitation is high and evapotranspiration 1ow, and are lower during summer, when precipitation is low and evapotranspiration high. The average volume of water entering the ponds from precipitation and overland runoff is greater than the volume discharging through evapotranspiration; the remainder seeps to the principal aquifer when the gradient favors flow in that direction.

Big Reed Pond, in the northeastern part of the area, discharges westward to Little Reed Pond over a large marshy area and through a small stream channel. Flow in the channel is too small to be measured with a current meter, however.

\section{Recharge to the Principal Aquifer}

The quantity of recharge to the principal aquifer is of primary interest because this aquifer is the sole source of long-term freshwater supply in the Montauk area. The aquifer is recharged solely by precipitation infiltrating the unsaturated zone through the till unit to the principal aquifer. The low vertical permeability of the till unit, where present, locally reduces

recharge to the underlying aquifer in several ways: (1) it increases overland runoff by retarding infiltration; (2) it causes infiltrating water to move laterally instead of downward, which results in eventual surface discharge as springflow and streamflow; and (3) it increases evapotranspiration by forming 
local perched water tables and marshes close to land surface. Thus, estimates of recharge to the principal aquifer are obtained by subtracting direct runoff, stream discharge, and evapotranspiration from total precipitation.

Although quantitative measurement of aquifer recharge is generally impossible, a rough regional estimate can be made from known values of precipitation, streamflow, and evapotranspiration through the following equation:

$$
\begin{aligned}
\text { Recharge }= & \text { Precipitation }-(\text { Evapotranspiration }+ \\
& \text { Base-flow discharge }+ \text { Overland runof } f)
\end{aligned}
$$

\section{Precipitation}

Detalled precipitation data have been collected on Long Island since the 1940 's; some records extend back to the late 19th century. Precipitation records in Montauk, however, are discontinuous and the sites scattered.

Precipitation has been recorded at (1) the now-abandoned Montauk Air Force Base during 1960-69; (2) the former site of the New York Ocean Science Laboratory (north of Fort Pond) during 1972-79; and (3) at the Suffolk County Water Authority we11 field (we11 S57357) since 1980. (Locations are shown in p1. 1). A composite graph of annual rainfall at three stations is given in figure 11A. Average annual precipitation over the discontinuous 16-year period was 41.49 inches with extremes ranging from 11.07 inches above average
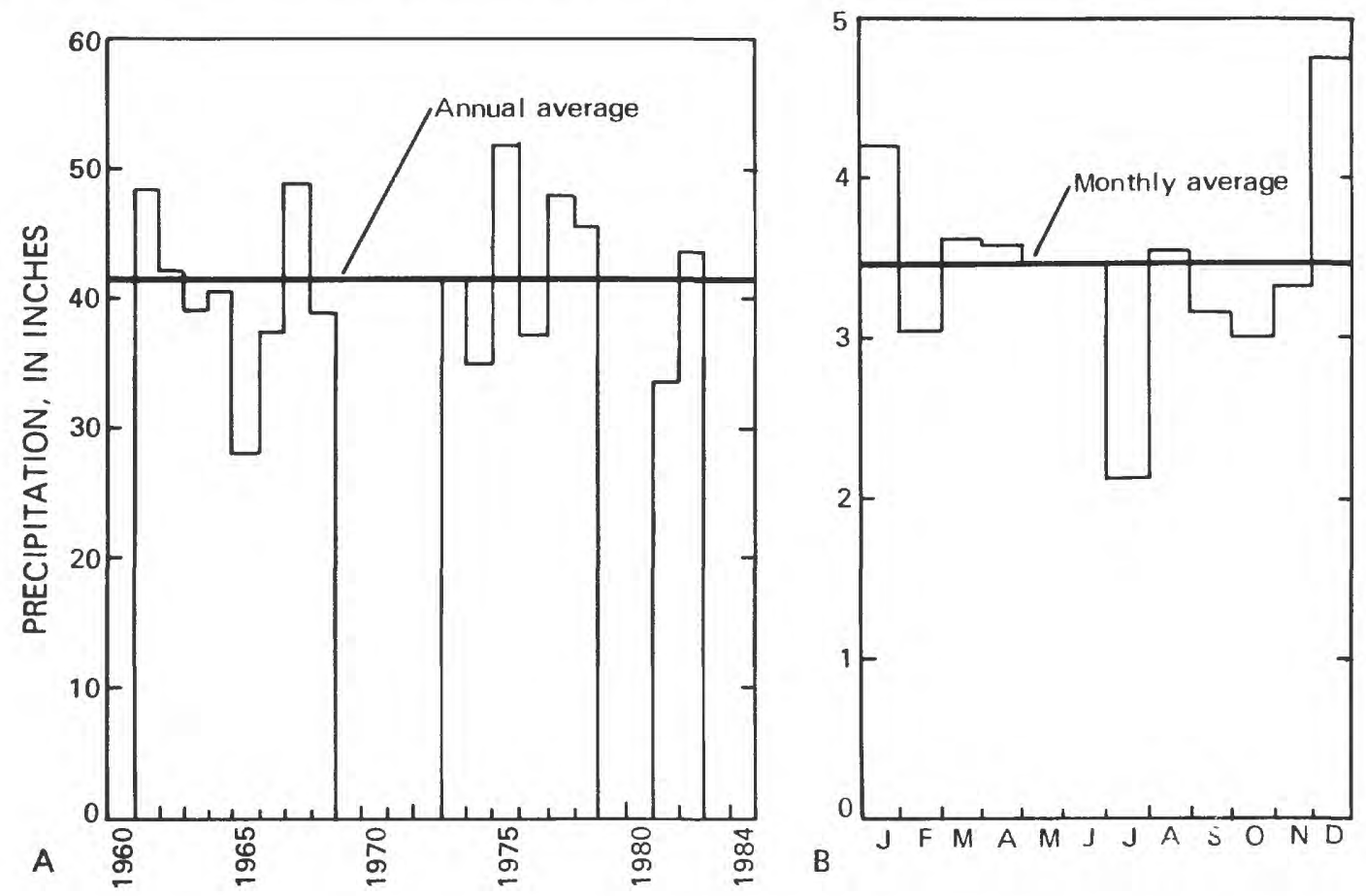

Figure 11.--Precipitation in Montauk area, averaged among records from Montauk Air Force Base (1960-69), New York Ocean Science Laboratory (1972-79), and Suffolk County Water Authority well field S57357 (1980-83): A. Annual average. B. Monthly average. 
to 13.22 inches below average. Monthly precipitation at the same three stations for the same 16 years is given in figure $11 \mathrm{~B}$. The highest average monthly precipitation occurs in December ( 4.78 inches) and the lowest in July (2.16 inches), with a monthly average of 3.46 inches.

Evaluation of precipitation and areal recharge from records as short and discontinuous as these is difficult. Data from the three separate locations do not overlap, which prevents comparison among the sites. Therefore, precipitation data from Montauk should be interpreted with caution.

Long-term continuous precipitation data have been collected on the south fork of Long Island at Bridgehampton ( $\mathrm{fig} \cdot 1$ ), approximately $19 \mathrm{mi}$ west of the village of Montauk, since 1930. Although the Bridgehampton area differs slightly from Montauk in its proximity to water, surrounding 1 and area, and direction of prevailing weather patterns, the two sites are similar enough to enable general conclusions about precipitation at Montauk. Annual precipitation at Bridgehampton during 1931-82 (fig. 12) averaged 45.00 inches. The average for the 16 years that records were kept at Montauk between 1960-80 was 41.49 inches, similar to that at Bridgehampton during the same period (43.79 inches) and slightly less than the 1931-82 average. Correlation of precipitation at Bridgehampton and Montauk by linear regression based on the 52-year average at Bridgehampton and 16 years of simultaneous record collection at Montauk yields an annual average precipttation of 42.54 inches at Montauk.

The precipitation regime of Long Island is described in detail in a report by Miller and Frederick (1969), which includes a map of annual average precipitation over the island. Extrapolation of the contours on that map indicates the average annual precipitation in the Montauk area to be in the 42- to 43-inch range, which is in close agreement with the values obtained from field measurements and correlation with Bridgehampton records.

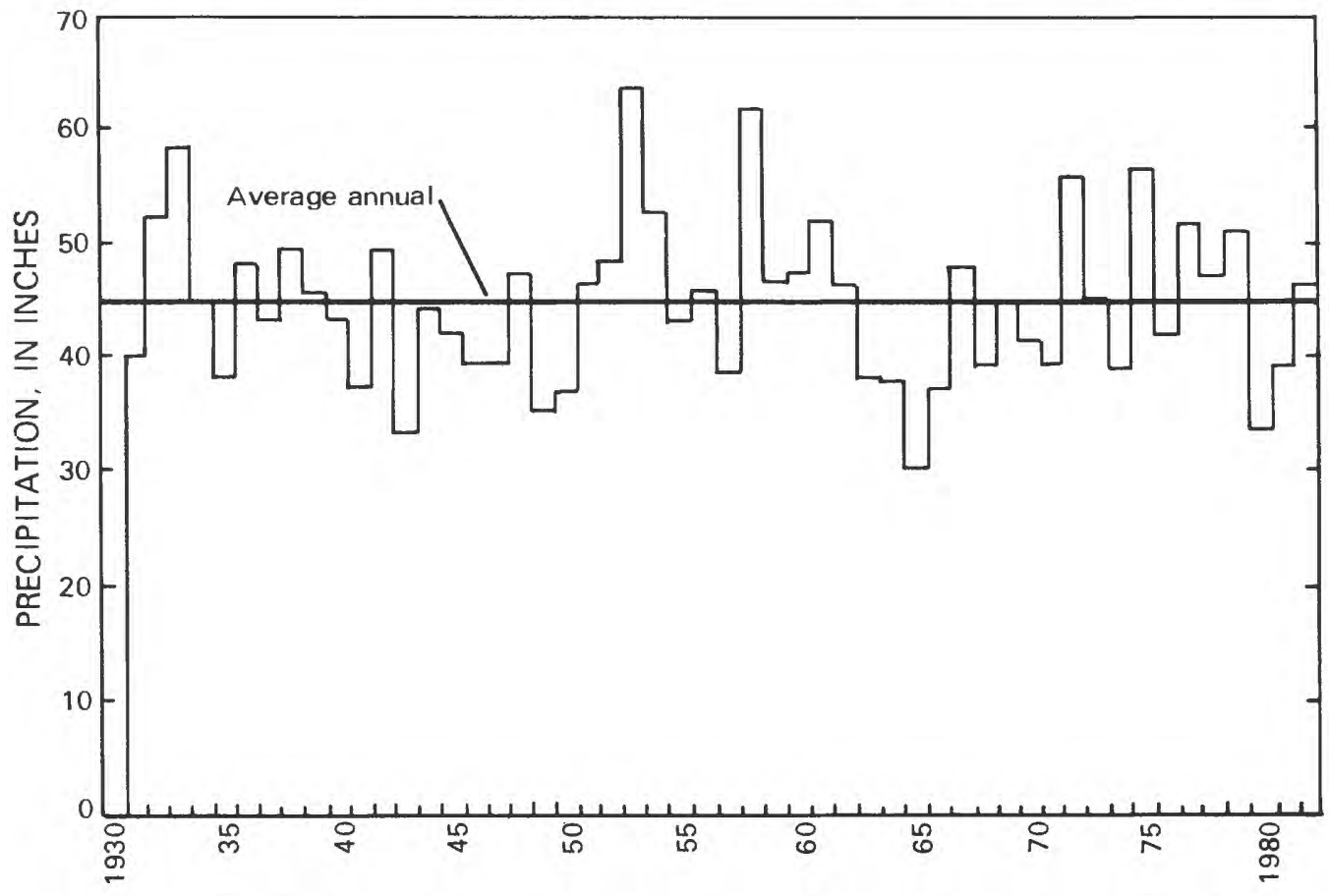

Figure 12.--Annual precipitation at Bridgehampton, 1931-82. 


\section{Evapotranspiration}

Evapotranspiration is the combination of evaporation from the 1 and and water surfaces and transpiration from the leaves of plants during the growing season. The rate of evapotranspiration depends upon temperature, humidity, air movement, solar radiation, soil moisture, plant cover, and land use.

Evapntranspiration cannot be measured directly; rather it must be calculated through empirical formulas from indirect measurements of evaporation from pans of various types. In areas where ground-water movement is sma11, evapotranspiration over a large area or drainage basin can be estimated from measurement of runof $f$ and precipitation. In the Montauk area, however, ground-water movement is not small, and discharge to the surrounding salt-water bodies cannot be measured; therefore, this method is not applicable.

Several estimates of evapotranspiration on Long Island have been published. Franke and McClymonds (1972, p. 20) estimated average annual potential evapotranspiration by two different methods--the method of Thornthwaite and Mather (1955, 1957), which yielded an evapotranspiration rate of $29 \mathrm{in} / \mathrm{yr}$, and the method of Meyer (1928), which yielded $32 \mathrm{in} / \mathrm{yr}$. Warren and others (1968), using rainfall-runoff relationships as well as the Meyer method and the Thornthwaite method, obtained estimates ranging from 21 to 26 in/yr. Vaupel and others (written commun., 1977), using the method of Thornthwaite and Mather (1957) and average precipitation at Mineola and Setauket, Long Island, obtained a rate of 21.6 in/yr--slightly less than half the annual precipitation.

Estimates of evapotranspiration on the south fork by Bart and others (1976, p. E24), using the method of Thornthwaite and Mather (1957) from mean weather data from 1930-75 and pan-evaporation data from Montauk for 1974 and early 1975, were $23.2 \mathrm{in} / \mathrm{yr}$, again roughly half the annual precipitation recorded at Bridgehampton.

Pan evaporation at Greenport, on the north fork (fig. 1), is measured by the National Oceanic and Atmospheric Administration; monthly and annual totals for 1972-81 are listed in table 3. Greenport is the location closest to Montauk for which a long continuous record of pan evaporation data is available. (The pan at Montauk was operated for only a short period.) Pan evaporation at Montauk in 1975 was 5.7 inches greater than at Greenport; this can be attributed to differences in the location of the pans with respect to nearby bodies of water, obstruction of wind, the typically greater wind on Montauk than the rest of Long Island, and possibly measurement error.

Evapotranspiration is difficult to quantify. Many different methods have been devised to estimate it, ranging from simple water-budget calculations to complex techniques based on energy-budget equations. Previous investigators have used several of these methods to estimate evapotranspiration on Long Island with results ranging from 21 to $32 \mathrm{in} / \mathrm{yr}$, roughly half the annual precipitation. Evapotranspiration on Montauk may be a few inches less than elsewhere on Long Island, averaging about $20 \mathrm{in} / \mathrm{yr}$, because the vegetation is stunted and thus takes up and transpires less water. 
Table 3.--Pan evaporation at Greenport, Long Island, N.Y., 1977-81.

[Data from National Oceanic and Atmospheric Administration; dashes Ind lcate data unavallable]

\begin{tabular}{|c|c|c|c|c|c|c|c|c|c|c|c|}
\hline \multirow[b]{2}{*}{ Year } & \multicolumn{11}{|c|}{ Evaporation, in inches per month } \\
\hline & $\begin{array}{l}\text { Jan. - } \\
\text { March }\end{array}$ & Apri1 & May & June & July & Aug. & Sept. & Oct. & Nov. & Dec. & Total \\
\hline 1981 & - & - & - & $6.59 a$ & 6.07 & 5.06 & 3.85 & $2.84^{a}$ & -- & - & 24.41 \\
\hline 1980 & - & -- & $5.74^{a}$ & 5.43 & $6.75^{a}$ & 5.07 & $5.44^{a}$ & 3.01 & -- & -- & 31.44 \\
\hline 1979 & -- & - & - & $6.57 a$ & 6.26 & $5.27^{a}$ & 4.35 & $2.80^{a}$ & - & - & 25.25 \\
\hline 1978 & -- & $4.35^{a}$ & 4.95 & 6.23 & $7.17^{a}$ & $4.72^{\mathrm{a}}$ & 4.07 & 3.43 & - & - & 34.92 \\
\hline 1977 & - & - & 5.91 & $5.80^{a}$ & $7.34^{a}$ & $5.32^{a}$ & $3.83^{a}$ & $3.04^{a}$ & -- & -- & 31.24 \\
\hline 1976 & -- & -- & -- & 5.83 & $6.44^{a}$ & $5.91^{\mathrm{a}}$ & 3.58 & $3.77^{a}$ & - & -- & 25.53 \\
\hline 1975 & -- & - & $5.04^{a}$ & $5.06^{a}$ & $6.95^{a}$ & $4.81^{a}$ & $3.42^{a}$ & $2.84^{a}$ & $1.74^{a}$ & -- & 29.86 \\
\hline 1974 & -- & - & -- & $4.95^{a}$ & 6.56 & $5.53^{a}$ & 4.09 & - & - & -- & 21.13 \\
\hline 1973 & -- & -- & 4.64 & $5.28 a$ & $6.52^{\mathrm{a}}$ & $4.93^{a}$ & $4.49^{a}$ & $2.98^{a}$ & - & -- & 28.84 \\
\hline 1972 & - & -- & 5.34 & $5.14^{a}$ & $5.86^{a}$ & $5.51^{a}$ & $4.28^{a}$ & $3.21^{a}$ & - & - & 29.25 \\
\hline Average & -- & 4.35 & 5.27 & 5.69 & 6.59 & 5.21 & 4.14 & 3.10 & 1.74 & - & 28.19 \\
\hline
\end{tabular}

a Monthly total estimated from partial record.

\section{Direct Runoff}

Direct runoff is the part of precipitation that flows overland to drainage ditches and streams without entering the ground-water system. Direct runoff must be distingulshed from stream base flow, which consists of ground water that seeps into the stream channels. In calculations of recharge to the ground-water body, direct runoff is subtracted from total precipitation. Not all runoff in the Montauk area discharges to streams and tidewater, however; in areas of internal drainage it enters ponds and marshes and evaporates or becomes part of total recharge.

Direct runof $f$ is affected by the (1) distribution, frequency, duration, and intensity of precipitation; (2) topography and type of vegetation; (3) soll characteristics, especially permeability; (4) amount of impervious area (roads, parking lots, roof tops, etc.); and (5) temperature and humidity of the a1r. Direct runoff on Long Island has been estimated to be less than 2 percent of precipitation (Cohen and others, 1968). Furthermore, direct runoff to south-shore streams draining glacial outwash has been estimated to average less than 5 percent of total measured streamflow, whereas direct runoff to streams draining the north shore may be as much as 10 percent of total streamflow (Franke and McClymonds, 1972). This difference is attributed to the slightly lower permeability of solls in areas underlain by till and to steeper land-surface gradients along the north shore. 
The volume of direct runof $f$ that enters streams could be estimated from continuous streamflow records, but none of the gaging stations on streams in the Montauk area have continuous records. Thus, only an empirical correlation between streams in the Montauk area and those draining the north shore of Long Island can be made. Franke and McClymonds (1972) found that, among the western Long Island streams they studied, the two that flow northward contain a higher percentage of direct runoff than the others. This they attributed to lower permeability of soils and steeper land-surface gradients on the north shore, both of which are also characteristic of the Montauk area. Direct runoff in the Montauk area is probably no more than about 2 percent of precipitation, or 1 inch, whereas elsewhere on Long Island it is less than 1 percent.

In summary, the quantity of water recharging the principal aquifer is equal to precipitation minus the sum of evapotranspiration and overland runoff. Average annual precipitation is approximately 42 inches, while evapotranspiration and direct runoff account for about 21 inches. The remaining 21 inches per year recharges the principal aquifer.

\section{Discharge from the Principal Aquifer}

Natural discharge from the principal aquifer occurs primarily as subsurface seepage to the surrounding saltwater bodies. In locations where the principal aquifer is under water-table conditions, some discharge may occur through seepage to surface-water bodies and through evapotranspiration. In addition, man-induced discharge occurs as ground-water pumpage. The principal aquifer is the primary source of freshwater in the Montauk area.

The major use of water is for residences, storefront businesses, and some fishing-industry operations. Irrigation is limited to golf courses and private lawns because the Montauk area contains no agriculture. Major water-use areas are shown in figure 13. The major water supplier in the

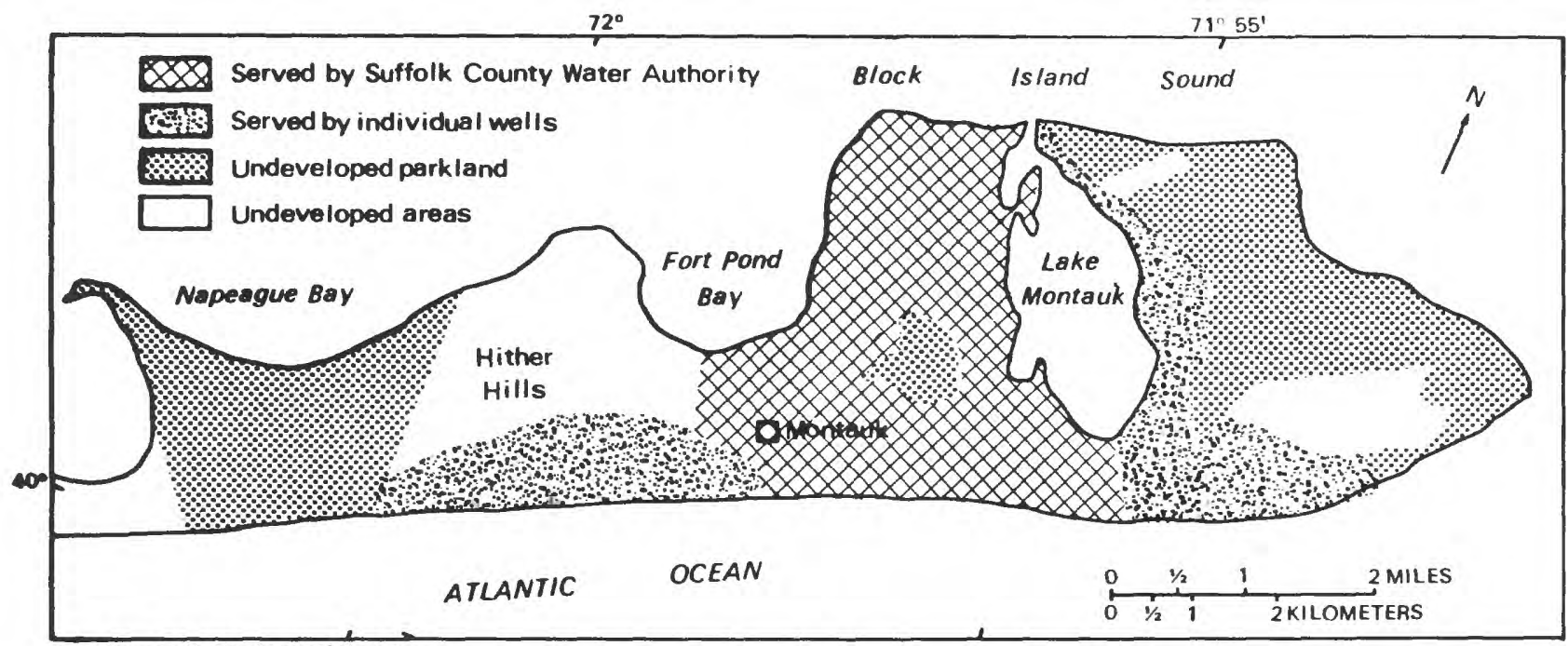

eee from U.S. Geological Survey

Stete base map, 1:500,000, 1974

Figure 13.--Water-supply distribution. 
Montauk area is Suffolk County Water Authority, which provides water to approximately 1,500 residences and businesses (fig. 13). Major individual water users not served by Suffolk County Water Authority are Hither Hills and Montauk Point State Parks, Montauk Elementary School, and several motels. Before being closed in 1980, the Montauk Air Force Base was also a major user of ground water. In areas not supplied by Suffolk County Water Authority, water is obtained from individual wells.

Average daily pumpage by the major water users in the Montauk area in 1981 was $0.534 \mathrm{Mgal} / \mathrm{d}$, but the rate varies greatly during the year because of the seasonal influx of vacationers during summer. Pumpage records of individual house wells are not kept. A graph of monthly pumpage by Suffolk County Water Authority in 1981 is given in figure 14. Monthly extremes ranged from a minimum of $0.224 \mathrm{Mgal} / \mathrm{d}$ in March to a maximum of $0.986 \mathrm{Mga} 1 / \mathrm{d}$ in July--an increase of more than 300 percent. Ground-water withdrawals for 1977-81 by major water users that report pumpage to New York State Department of Envi ronmental Conservation are given in table 4. The total reported pumpage ranges from $0.494 \mathrm{Mga} 1 / \mathrm{d}$ in 1977 to $0.628 \mathrm{Mgal} / \mathrm{d}$ in 1980, which indicates an increasing trend.

\section{Table 4.--Major estimated ground-water withdrawals in the Montauk area, 1977-81.}

[Records from New York State Department of Envi ronmental Conservation; dashes indicate pumpage not reported]

\begin{tabular}{|c|c|c|c|c|c|c|}
\hline We11 owner 1 & We11 & $\frac{\text { Pumpa }}{1977}$ & ge, in & mil1ion & gallons & $\frac{\text { per day }}{1981}$ \\
\hline $\begin{array}{l}\text { Suffolk County Water } \\
\text { Authority }\end{array}$ & S51274 & 0.030 & 0.052 & 0.117 & 0.145 & 0.048 \\
\hline $\begin{array}{l}\text { Suffolk County Water } \\
\text { Authority }\end{array}$ & S3615 & .031 & .093 & .050 & .089 & .086 \\
\hline $\begin{array}{l}\text { Suffolk County Water } \\
\text { Authority }\end{array}$ & S30208 & .091 & .076 & .165 & .170 & .150 \\
\hline $\begin{array}{l}\text { Suffolk County Water } \\
\text { Authority }\end{array}$ & S 18762 & .034 & .069 & .045 & .057 & .057 \\
\hline $\begin{array}{l}\text { Suffolk County Water } \\
\text { Authority }\end{array}$ & S30207 & .070 & .082 & .076 & .069 & .085 \\
\hline $\begin{array}{l}\text { Suffolk County Water } \\
\text { Authority }\end{array}$ & S51275 & .178 & .085 & .080 & .050 & .074 \\
\hline $\begin{array}{l}\text { Suffolk County Water } \\
\text { Authority }\end{array}$ & S57357 & .036 & .023 & .024 & .023 & .020 \\
\hline Gurney's Inn & S66373 & -- & -- & - & .004 & .004 \\
\hline Hither Hills State Park & $\begin{array}{l}\text { S } 5997 \\
\text { S } 29982\end{array}$ & .018 & .011 & .013 & .014 & -- \\
\hline Montauk Point State Park & $\begin{array}{l}S 7421 \\
\text { S60485 }\end{array}$ & .002 & .001 & .010 & .001 & -- \\
\hline Montauk Elementary School & S64346 & -- & -- & $<.001$ & .002 & .006 \\
\hline Panoramic View Apartments & S13451 & .004 & .004 & .004 & .004 & .004 \\
\hline TOTAL & & .494 & .496 & .585 & .628 & .534 \\
\hline
\end{tabular}




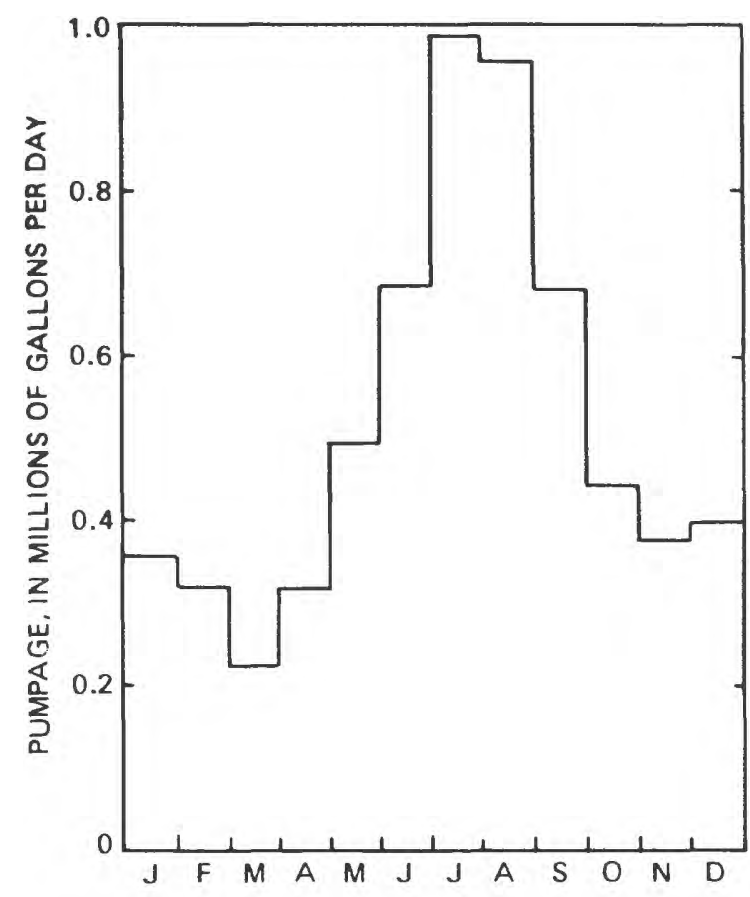

Figure 14.

Monthly ground-water

withdrowal rates

by Suffolk County Water

Authority, 1981.

\section{Freshwater/Saltwater Relationships}

Where the freshwater in an unconsolidated aquifer of an island or peninsula is in contact with tidewater, the freshwater tends to float on top of the saltwater owing to density differences. The relationship between freshwater and saltwater commonly cited is described by the Ghyben-Herzberg relationship:

$$
Z_{s}=\frac{\rho_{f}}{\rho_{s}-\rho_{f}} Z_{W}
$$

where: $Z_{s}=$ freshwater thickness below sea leve1,

$\mathrm{Z}_{\mathrm{w}}=$ water-table altitude above sea level,

$\rho_{f}=$ freshwater density, and

$\rho_{s}=$ saltwater density.

For example, assuming that $\rho_{f}=1.0$ and $\rho_{s}=1.025$ for a freshwater lens floating on saltwater, for every $1 \mathrm{ft}$ of freshwater above sea level there will be $40 \mathrm{ft}$ of freshwater below sea level. This is the basis for the commonly quoted 1:40 ratio between water-table altitude and depth to the freshwater/ saltwater interface below sea leve1. This relationship assumes that both the fresh and saltwater are under static conditions, that the aquifer is homogeneous and isotropic, and that the interface is sharp--that is, with no zone of diffusion. Under conditions of steady-state ground-water flow in an isotropic aquifer, the Ghyben-Herzberg relationship will tend to over- or underestimate freshwater thickness where vertical gradients occur, such as at shoreline discharge boundaries, in areas with large regional pumpage, and near individual pumping wells. 
As stated previously, the freshwater/saltwater interface is not a sharp boundary but a zone of diffusion whose width within the formation depends upon the grain size and permeability and, in nonsteady-state conditions, the amount of movement of the interface. Generally, as the interface moves, especially in a cyclic fashion, such as near an intermittently pumping we11, the zone of diffusion can spread to many times its steady-state thickness by mixing and mechanical dispersion.

\section{Depth of Freshwater/Saltwater Interface}

With a given density contrast between fresh and saltwater, the location of the interface and the thickness of the freshwater lens above it are determined by the rates of recharge and discharge and by aquifer hydraulic conductivity. Burns and others (1975) demonstrated the effect of anisotropy (the ratio between vertical and horizontal hydraulic conductivity) on the depth of the interface with a numerical cross-section mode1. The maximum depth to the interface in their study decreased by almost 100 percent as the anisotropy was increased from 1:1 to 1:1,000. Nemickas and Koszalka (1982) reported the ratio of vertical to horizontal hydraulic conductivity over the south fork to range from nearly $1: 1$ to almost $1: 100$.

A map showing the altitude of the saltwater interface (fig. 15) was drawn from data obtained from nine deep test holes drilled for this project, from drillers' logs, and from previously published information in Nemickas and Koszalka (1982). The depth of the interface in four hydrogeologic sections is shown in plate 2 .

During the 1980-81 test drilling, the depth of the interface was sought by two methods wherever possible--the filter-press method and electric resistivity geophysical logs. The filter-press method is an adaptation of techniques used in the petroleum industry; its use is described in detail by Lusczynski (1961).

In some places, use of both methods was not possible. For example, where clay was abundant, the logging probe of ten became fouled with clay and gave erroneous results, and in coarse-grained material, the quantity of filtrate obtained by the filter-press method was insufficient for chloride analysis. Acceptable results were generally obtained by one of the two methods, however.

Resulting data indicate the zone of diffusion surrounding Montauk to be relatively narrow--generally less than $20 \mathrm{ft}$ in thickness. Short- and long-normal resistivity logs as well as some natural gamma logs are shown on the four cross sections in plate 2.

The freshwater/saltwater interface map (fig. 15) indicates a general altitude of about $100 \mathrm{ft}$ below sea level and a maximum depth of $250 \mathrm{ft}$ below sea level in the Prospect Hill area. This maximum depth is anomalous, however. The freshwater at this depth is within a thick sequence of clay and may have been native to the formation at the time of deposition and not the result of current conditions. The clay, being highly impermeable, has not allowed the saltwater to invade the formation at this location. In any case, the depth of the interface within the clay unit is not important to the area's 
water resources because most of this freshwater is not easily withdrawn by pumping wells. At Hither Hills, the maximum depth to saltwater is approximately $150 \mathrm{ft}$ below sea level; here the interface is either within or beneath the marine clay unit.

More important than the location of the freshwater/saltwater interface is the thickness of aquifer containing freshwater. To calculate the freshwater aquifer thickness on the Montauk peninsula, it is first necessary to compare the altitude of the base of freshwater (interface depth) with the altitude of the top of the marine clay unit because the higher of the two forms the base of the freshwater system. For example, in the central section of Hither Hills, the clay unit is less than $100 \mathrm{ft}$ below sea level, and the interface is as much as $50 \mathrm{ft}$ deeper. The next step is to compare the altitude of the base of the confining unit that overlies the principal aquifer with the

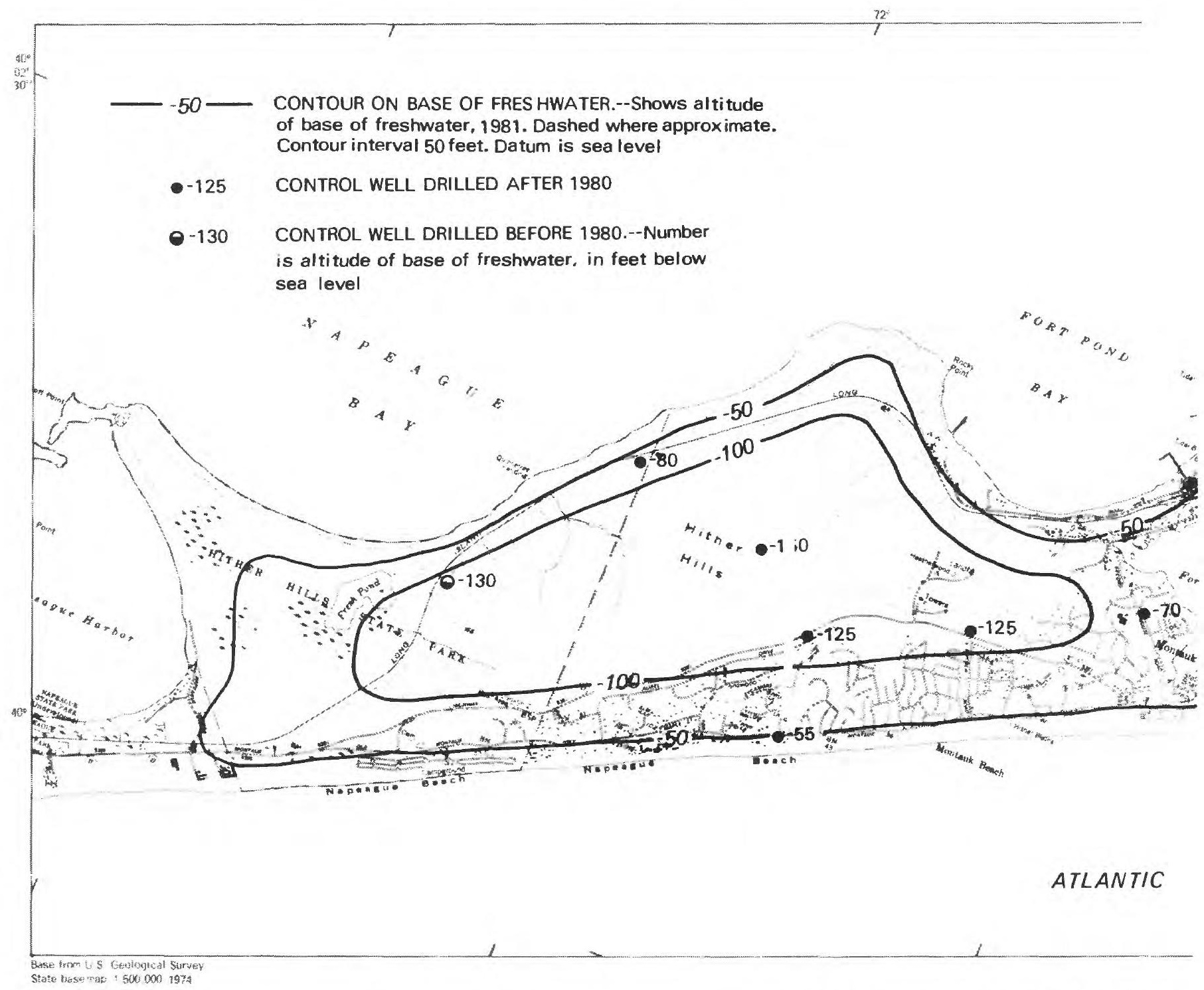

Figure 15.--Altitude of the 
potentiometric head in the aquifer because the lower of the two forms the top of the freshwater aquifer thickness.

A map showing the total aquifer thickness containing freshwater (fig. 16) was compiled from maps of the marine clay unit (fig. 4), the base of the till unit (fig. 5), the potentiometric surface of the principal aquifer (fig. 9), and the depth of the freshwater/saltwater interface (fig. 15). Although the map of the freshwater thickness in the aquifer only approximates the actual conditions, it provides a general overview of the supply of available freshwater. The thickness indicated is significantly different from that implied by the interface map (fig. 15); for example, the depth to the interface in Hither Hills is as much as 150 feet below sea level, but the thickness of recoverable freshwater is less than $100 \mathrm{ft}$ because of the marine clay unit.

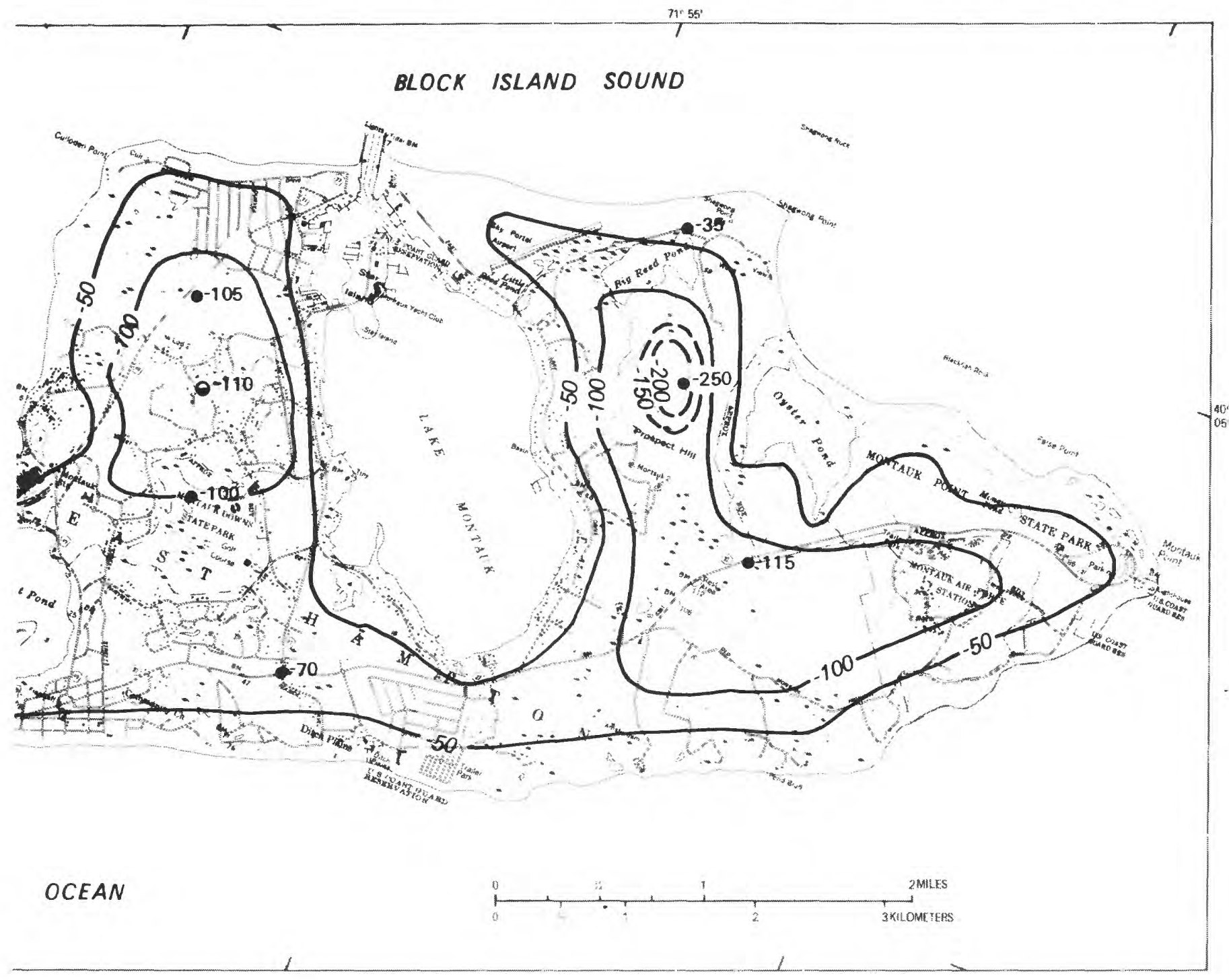

freshwater/saltwater interface. 


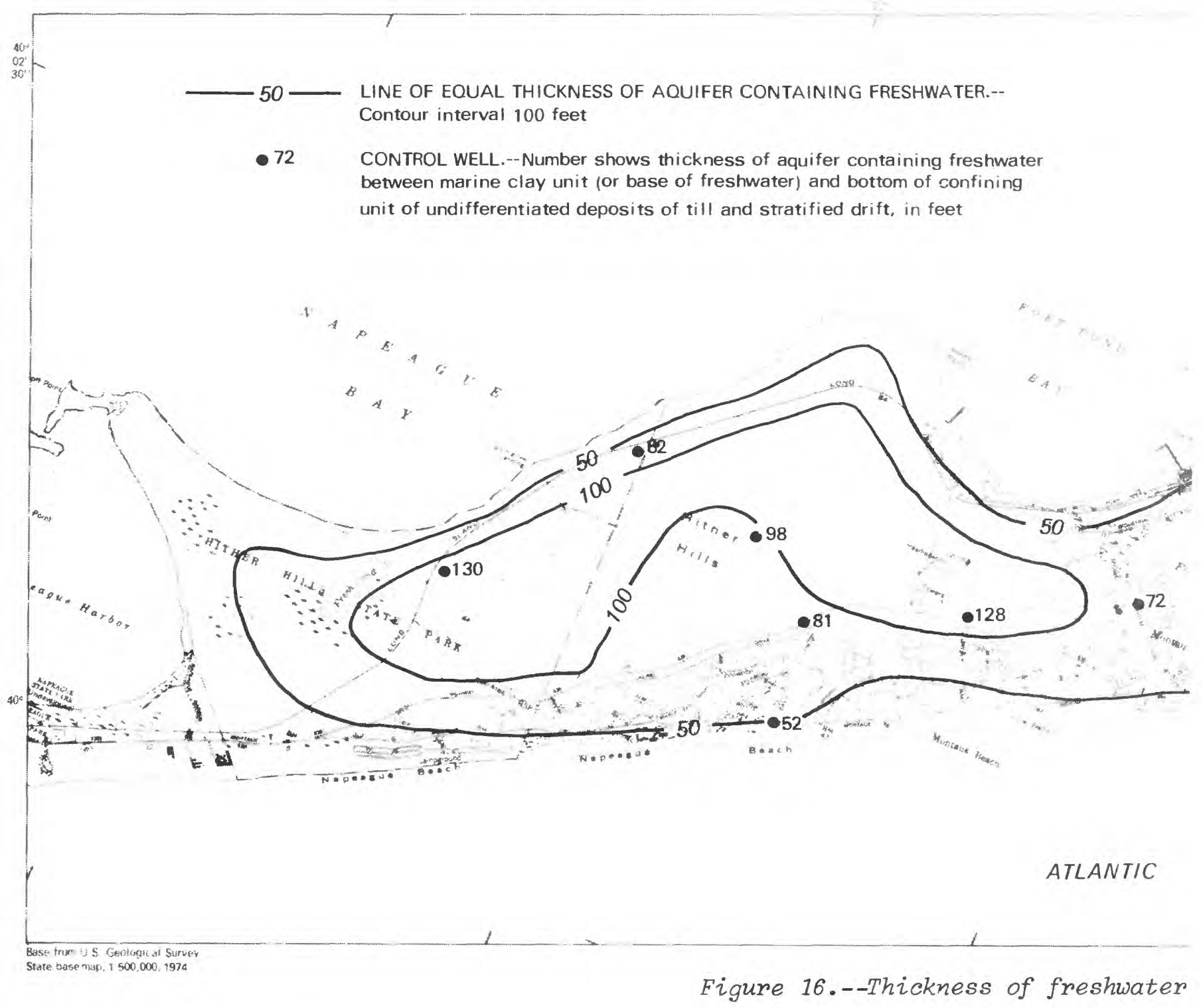

\section{Movement of Freshwater/Saltwater Interface}

The freshwater/saltwater interface moves in response to changes in hydraulic head in the aquifer, which in turn result from changes in the balance between ground-water recharge and discharge. As hydraulic head declines, the saltwater interface moves landward and upward, and, when the head in the aquifer increases, the depth to the interface increases. To assess long-term trends in movement of the saltwater interface, several deep test holes were finished as permanent observation wells with screens either within the zone of diffusion or just above it. Thus, any vertical movement of the zone of diffusion can be detected by a change in chloride concentration.

Eight wells were installed to detect movement of the interface, and water samples were collected semiannually and analyzed for chloride concentration by Suffolk County Department of Health Services; results are shown in table 5. 


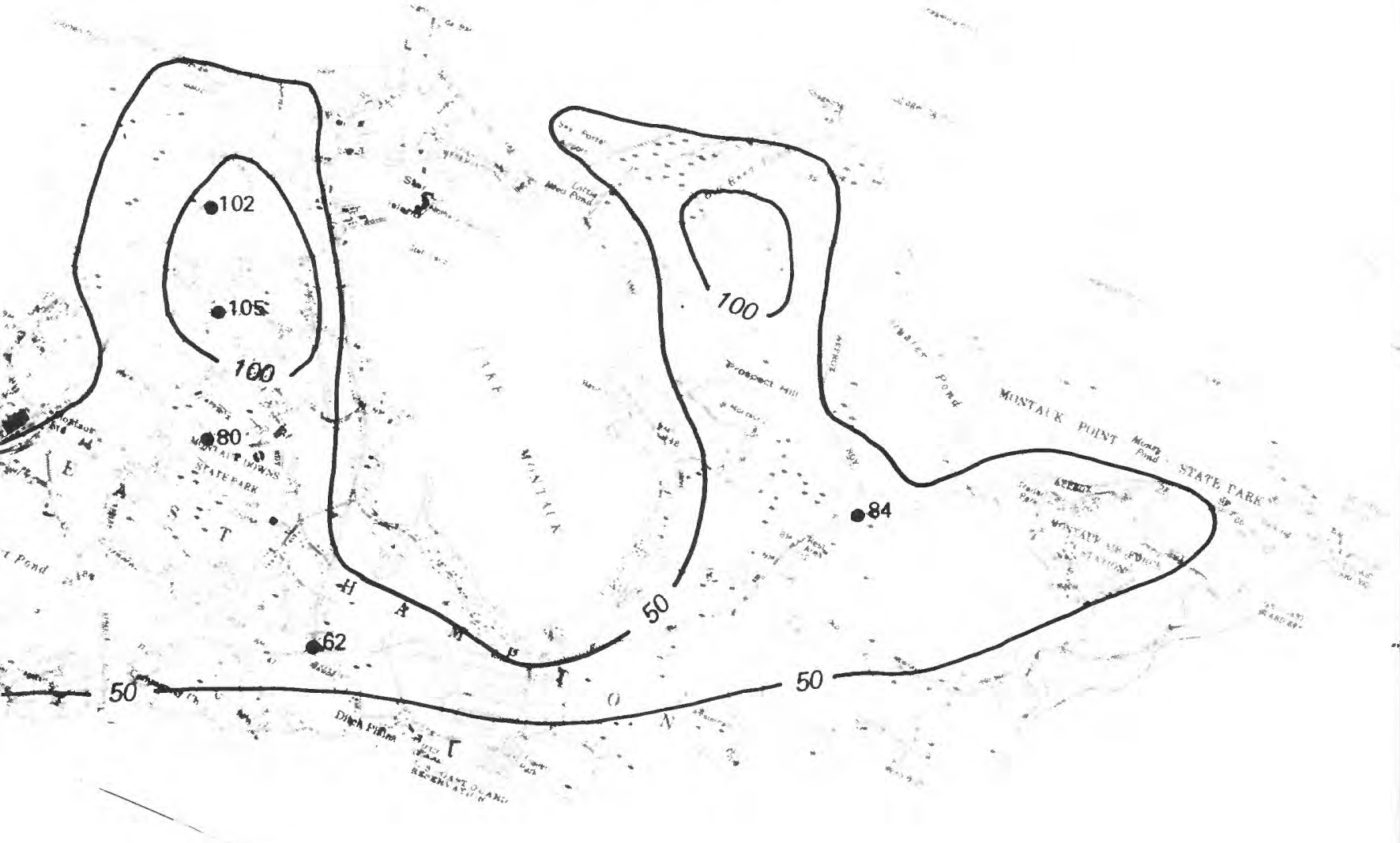

OCEAN

in principal aquifer.

We1ls S70255, S70256, and S70257, screened within the zone of diffusion, yielded chloride concentrations in thousands of milligrams per liter; the other five, screened above the zone of diffusion, had chloride concentrations ranging from 15 to $40 \mathrm{mg} / \mathrm{L}$. (Well locations are shown in p1.1.)

Four or five samples were collected from each well from December 1980 through November 1982 at 6-month intervals. Sampling in the spring and fall was expected to reveal a cyclic pattern in chloride concentrations as the freshwater thickness fluctuated with the seasonal variations in recharge and pumping, but the data ( $t a b l e ~ 5)$ show neither a cyclic pattern nor any clearcut increasing or decreasing trend. This apparent stability may be due to two factors: (1) movement of the saltwater interface both seasonally and over the long term is too small to cause discernible chemical changes, and (2) the somewhat random pattern of chloride concentration could be a result of the field techniques. For example, if the wells were pumped too long before 
sampling, saltwater would be drawn toward the observation well, giving an elevated chloride concentration in the sample. Furthermore, the period of sampling is insufficient to reveal long-term trends; several more years of sampling and analysis would be needed to reveal general trends.

Table 5.--Chloride concentrations from wells screened in or near the freshwater/saltwater interface. 1

[All concentrations are in $\mathrm{mg} / \mathrm{L}$; well locations are shown in $\mathrm{pl} .1$. ]

\begin{tabular}{|c|c|c|c|c|c|c|c|}
\hline $\begin{array}{c}\text { Nell } \\
\text { number }\end{array}$ & $\begin{array}{l}\text { Screened } \\
\text { interval } \\
\text { (ft below } \\
\text { sea level) }\end{array}$ & Date & $\begin{array}{l}\text { Chloride } \\
\text { concen- } \\
\text { tration } \\
\end{array}$ & $\begin{array}{c}\text { We11 } \\
\text { number }\end{array}$ & $\begin{array}{l}\text { Screened } \\
\text { interval } \\
\text { (ft below } \\
\text { sea level) }\end{array}$ & Date & $\begin{array}{l}\text { Chloride } \\
\text { concen- } \\
\text { tration }\end{array}$ \\
\hline S70255 & $141-146$ & $\begin{array}{r}12-4-80 \\
3-26-81 \\
9-15-81 \\
3-29-82 \\
11-24-82\end{array}$ & $\begin{array}{l}2,850 \\
2,100 \\
3,100 \\
3,400 \\
3,400\end{array}$ & s70259 & $54-59$ & $\begin{array}{r}4-7-81 \\
9-14-81 \\
3-25-81 \\
11-23-81\end{array}$ & $\begin{array}{l}32 \\
33 \\
27 \\
26\end{array}$ \\
\hline S70256 & $98-103$ & $\begin{array}{r}12-18-80 \\
4-9-81 \\
9-22-81 \\
4-1-82 \\
12-7-82\end{array}$ & $\begin{array}{l}3,100 \\
2,400 \\
2,200 \\
2,900 \\
5,000\end{array}$ & S70260 & $62-67$ & $\begin{array}{r}4-16-81 \\
9-14-81 \\
3-31-82 \\
11-24-82\end{array}$ & $\begin{array}{l}45 \\
46 \\
42 \\
45\end{array}$ \\
\hline S 70257 & $54-59$ & $\begin{array}{r}1-19-81 \\
3-26-81 \\
9-14-81 \\
3-29-82 \\
11-22-82\end{array}$ & $\begin{array}{r}315 \\
780 \\
3,100 \\
2,600 \\
820\end{array}$ & S70261 & $91-96$ & $\begin{array}{r}5-7-81 \\
9-24-81 \\
3-31-82 \\
11-19-82\end{array}$ & $\begin{array}{l}22 \\
17 \\
18 \\
20\end{array}$ \\
\hline S70258 & $75-80$ & $\begin{array}{r}3-26-81 \\
4-10-81 \\
9-15-81 \\
3-25-81 \\
11-23-82\end{array}$ & $\begin{array}{l}43 \\
20 \\
21 \\
14 \\
17\end{array}$ & S70262 & $108-113$ & $\begin{array}{r}5-21-81 \\
9-21-81 \\
3-30-82 \\
11-22-82\end{array}$ & $\begin{array}{l}30 \\
28 \\
29 \\
28\end{array}$ \\
\hline
\end{tabular}

1 Data from Suffolk County Department of Health Services

\section{Effects of Pumping}

When wells are pumped, the resulting decrease in freshwater head near the well causes the saltwater interface beneath the well to rise in what is known as saltwater upconing. A simplified diagram of saltwater upconing is shown in figure 17. Saltwater upconing can be controlled or minimized through proper well design and controlled pumping rates, as discussed in a later section, "Site-Specific Considerations." 


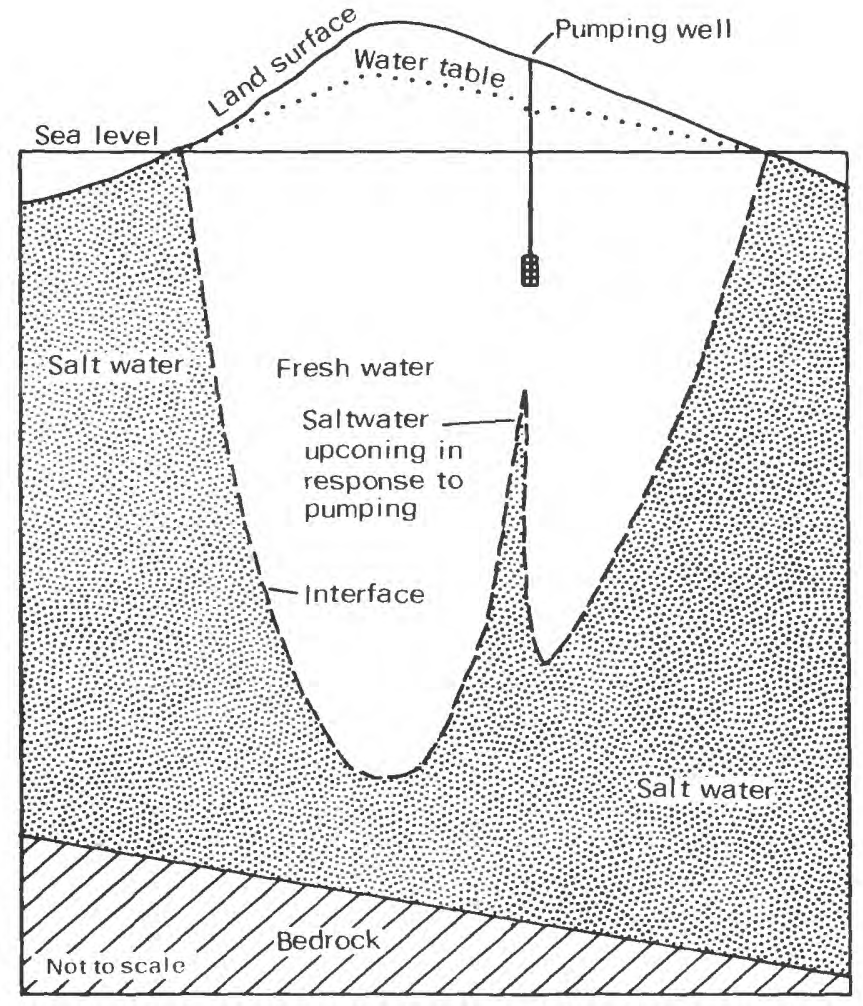

Figure 17.

Simplified response of freshwater/saltwater interface to heavy ground-water pumping. (Modified from Nemickas and Koszalka, 1977.)

Suffolk County Water Authority regularly collects and analyzes water samples from their public-supply wells to assure continued high quality. In the Montauk area, water samples are collected biweekly and analyzed for chloride; the resulting data are used to regulate pumping cycles to avoid serious upconing at the public-supply wells.

To depict the effects of the pumping schedule on chloride concentrations, 1981 chloride concentration and pumpage data are plotted in relation to time in figure 18. When pumpage was low (January to May), chloride concentrations remained near the background levels for the area, about $25 \mathrm{mg} / \mathrm{L}$. In late May, however, when the heavy seasonal stress began, the chloride concentration began to increase and, by late June, had reached a peak of about $80 \mathrm{mg} / \mathrm{L}$. At that time, the well was taken out of service for a few days until the chloride concentration returned to the $25-\mathrm{mg} / \mathrm{L}$ range. This pattern was repeated until October. Most other public-supply wells in the Montauk area exhibit a similar correlation between pumpage and chloride concentration.

The chloride trend was also examined by plotting several years of chloride levels against time and fitting a straight line through the data; graphs for the period of record for three public-supply wells are shown in figure 19. Although the relationship is not linear, the data reveal long-term trends. All graphs show a seasonal pattern with peaks during the summer and early fall. After the seasonal peaks, chloride concentrations do not always return to their previous level, as evidenced by the positive slope of the straight line for two of the wells (S51274 and S18762). The reason is that during summer, when water demand is at its peak, the public-supply wells are 
pumped until chloride concentrations begin to rise. When the wells are shut down to let the saltwater cone recede, some mixing between freshwater and saltwater occurs, and this mixing broadens the zone of diffusion and causes higher background concentrations at the pumping we11. This in turn increases the salinity of water pumped in the future.

Not all public-supply wells show the same changes in salinity with pumping because saltwater upconing is dependent upon three factors--well design, pumping schedule, and aquifer properties (hydraulic conductivity and storage coefficient). For example, the hydrograph of we11 S51275 (fig. 19C) shows a slight decreasing trend in chloride concentration during 1975-82, in contrast to the clear upward trend in the other two wells. In reaiity, the chloride concentration at well S51275 is not changing significantly; the apparent downward trend is probably an artifact of the data scatter and the method of analysis. However, this lack of increase suggests that increases in chloride can be minimized, under certain geohydrologic conditions, through proper well design and pumping schedule.

Well S51275 is in an area that is not confined by the till unit (fig. 5); therefore the aquifer has a greater storage capacity here than elsewhere. (In an unconfined aquifer, the storage characteristics are mostly dependent upon the specific yield of the aquifer material, whereas in confined aquifers, specific storage is the controlling factor.) In an unconfined aquifer, a unit decline in the water table will cause a large volume of water to be released from storage as a result of dewatering of the soil pores, whereas a unit decline in the potentiometric surface of a confined aquifer will result only in the release of water from compressive storage and aquifer compaction. The volume of water released from storage from an unconfined aquifer can be several orders of magnitude greater than from a confined aquifer under similar conditions; thus, an unconfined aquifer can provide the same yield as a confined aquifer with smaller head changes over a less extensive area. Smaller drawdowns within the unconfined aquifer will in turn result in less extensive saltwater upconing beneath the pumping well. This factor has

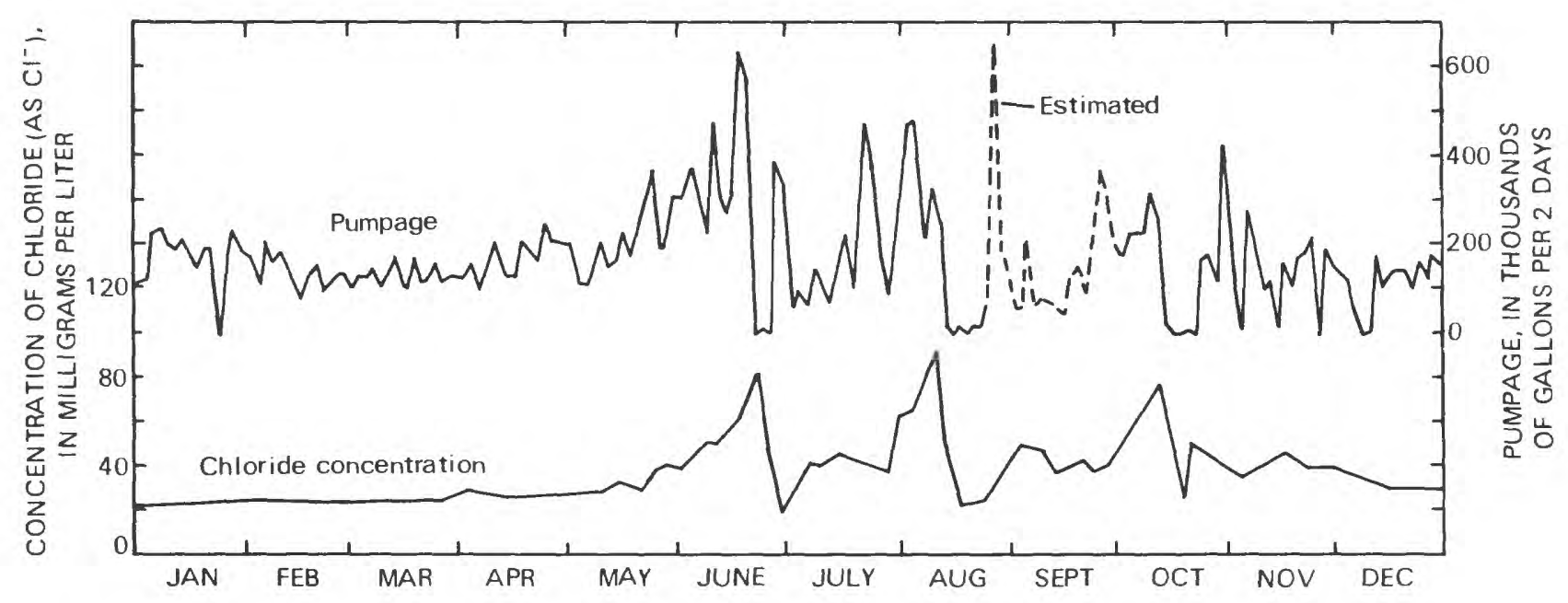

Figure 18.--Chloride concentration and pumpage at Suffolk County Water Authority well S30207 between Fort Pond and Lake Montauk in 1981. (Location is shown in pl. 1.) 
undoubtedly contributed to the lower chloride concentration in water from we 11 S51275, but the well design and pumping schedule have probably contributed a1so. Linear regression analyses of chloride concentrations of 1978-82 revea1 a slight upward trend, which may indicate future increases.

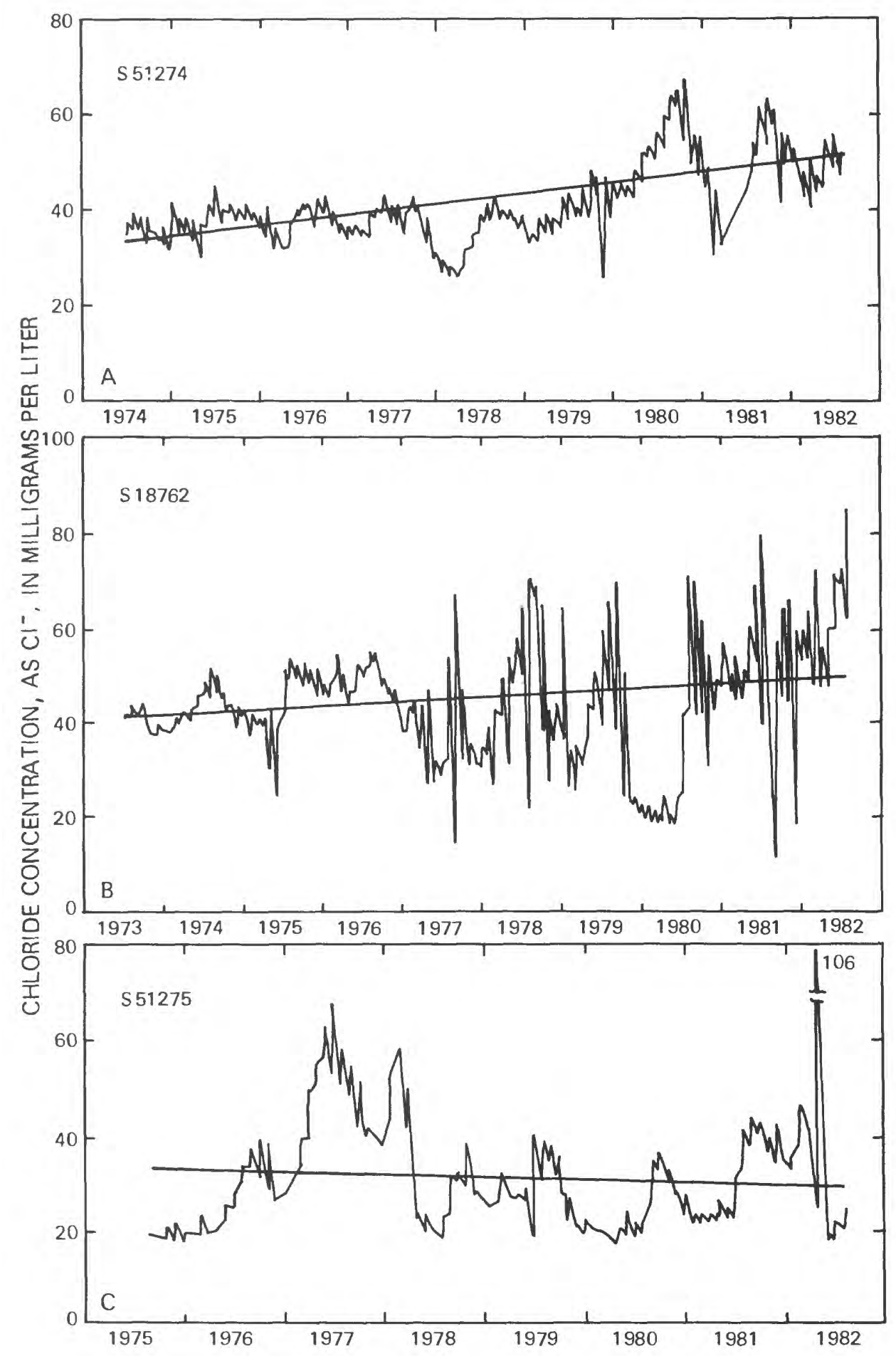

Figure 19.--Chloride concentrations from early 1970's through 1982 at three public-supply wells. (Well locations are shown in pl. 1.) 


\section{Hydraulic Characteristics of the Principal Aquifer}

Evaluating the water-resources potential of an area requires a knowledge of the water-bearing characteristics of the aquifer. Numerical flow models require estimates of these aquifer properties to solve the basic flow equations that give predictions of hydraulic heads under specified conditions of stress. An aquifer's productivity and reponse to stress are controlled not only by its dimensions and boundary conditions, but by its hydraulic properties-hydraulic conductivity and storage characteristics. These factors are usually measured indirectly through the analysis of aquifer response to controlled stress or are estimated through other indirect means. Fetter (1971) obtained hydraulic-conductivity values for the upper glacial aquifer on the south fork and the principal aquifer in the Montauk area from aquifer pumping-test and specific-capacity data; values ranged from $43 \mathrm{ft} / \mathrm{d}$ to 435 $\mathrm{ft} / \mathrm{d}$, and 60 percent of the values were between 120 and $187 \mathrm{ft} / \mathrm{d}$. Similarly, calculations of hydraulic conductivity by Nemickas and Koszalka (1982), based upon specific-capacity data, ranged from $200 \mathrm{ft} / \mathrm{d}$ to $750 \mathrm{ft} / \mathrm{d}$, with 70 percent of the values between 280 and $400 \mathrm{ft} / \mathrm{d}$. In this study, estimates of aquifer characteristics were made from (1) specific-capacity data supplied by Suffolk County Water Authority on nine public-supply wells, and (2) an aquifer-pumping test at one of these wells. Both data sources are described in a subsequent section.

\section{Determination From Specific-Capacity Data}

A method of calculating hydraulic conductivity from specific-capacity data, and the sensitivity of the calculations to changes in the value of various other aquifer properties, are discussed in detail in Bredehoeft (1963). In this study a modified version of Bredehoeft's method, described in McClymonds and Franke (1972), was used to estimate aquifer hydraulic conductivity from specific-capacity data. The equation used for calculating hydraulic conductivity is:

$$
\mathrm{K}=114.6 \mathrm{~W}(\mathrm{u}) \stackrel{\mathrm{Q}}{\mathrm{sL}}
$$

where: $\mathrm{K}=$ average hydraulic conductivity of the material surrounding the well screen, in $(\mathrm{gal} / \mathrm{d}) / \mathrm{ft}^{2}$;

$\mathrm{Q}=$ discharge of the pumping well, in gal/min;

$\mathrm{s}=$ drawdown of the pumping well, in $\mathrm{ft}$;

$\mathrm{L}=1$ ength of the well screen, in $\mathrm{ft}$;

$$
\begin{aligned}
W(u)= & \text { well function where } u=1.87 \mathrm{r}^{2} \frac{\mathrm{S}}{\mathrm{Tt}} \text {; and } \\
\mathrm{r} & =\text { distance to point of observation (in this case, well radius), } \\
& \text { in } \mathrm{ft} ; \\
\mathrm{S} & =\text { storage coefficient (dimensionless); } \\
\mathrm{T} & =\text { transmissivity, in }(\mathrm{ga} / \mathrm{d}) / \mathrm{ft} ; \text { and } \\
t & =\text { time since pumping began, in days. }
\end{aligned}
$$

As can be seen from the equation, calculation of hydraulic conductivity requires initial estimates of storage coefficient and transmissivity; therefore, an iterative method of refining these values is necessary. 
Implicit in using this equation to estimate hydraulic conductivity is the assumption that all water is supplied to the well along horizontal flow lines from the aquifer material surrounding the well screen. In reality, some water flows to the well from both above and below the screen, especially if the well was constructed with a gravel pack surrounding the screen zone. (Grave1packing the screen zone also increases the effective radius of the well screen, causing error in the value of $r_{*}$ )

Hydraulic-conductivity values obtained by this method from public-supply well data are of ten much greater than the aquifer average, largely because most public-supply wells tap a zone of relatively high permeability and because this method assumes horizontal flow to the well screen.

Lateral hydraulic conductivity is generally much greater than vertical conductivity because aquifer material was deposited in horizontal bedding planes. However, only horizontal hydraulic conductivity can be estimated from specific-capacity data.

Calculating hydraulic conductivity from specific-capacity data by equation 3 requires an estimate of the storage characteristics of the aquifer. If the aquifer is unconfined (water-table conditions), the specific yield might range from 0.10 to 0.40 , and the calculated aquifer hydraulic conductivity would be relatively insensitive to variations in specific yield over this range. If the aquifer is confined, however, the storage-coefficient values could be in error by several orders of magnitude. Table 6 lists hydraulic-conductivity values at nine Suffolk County Water Authority wells; the values were calculated from assumed values of 0.25 for specific yield for water-table conditions and 0.025 for specific storage for confined conditions. Although the till unit confines the principal aquifer in places, it is not a "tight" clay, nor is it continuous; therefore, the principal aquifer probably responds as a water-table aquifer in some areas and as a leaky confined aquifer elsewhere. The storage coefficient of the principal aquifer probably varies locally.

Table 6.--Horizontal hydraulic conductivity ${ }^{1}$ of the principal aquifer in the Montauk area.

[Wel1 locations are shown in p1. 1.]

\begin{tabular}{lc}
\hline $\begin{array}{c}\text { We11 } \\
\text { number }\end{array}$ & $\begin{array}{c}\text { Hydraulic conductivity } \\
(\text { in } \mathrm{ft} / \mathrm{d})\end{array}$ \\
\hline S3615 & 240 \\
S30207 & 280 \\
S30208 & 260 \\
S51274 & 130 \\
S51275 & 350 \\
S57357 & 240 \\
S60897 & 330 \\
S70008 & 190 \\
S70155 & 250 \\
\hline
\end{tabular}

1 Estimated from specific-capacity data. 
Under pumping conditions, the potentiometric surface of the principal aquifer could be locally drawn down below the base of the upper confining unit. At this point, the aquifer response would change from that of a confined system with a low specific storage to that of a water-table system with a specific yield several orders of magnitude greater than the storage coefficient.

Comparison of public-supply well locations ( $p 1.1$ ) with areas where the principal aquifer is confined ( $\mathrm{fig}$. 5) shows that al1 wells except S51275, near Fort Pond, are in areas where the principal aquifer is confined. Therefore, aquifer hydraulic conductivity was calculated from a storage coefficient of 0.025 except at well S51275, where a specific yield of 0.25 was used.

The hydraulic conductivity values for the principal aquifer (table 6), as computed from specific-capacity data provided by Suffolk County Water Authority, range from $130 \mathrm{ft} / \mathrm{d}$ to $350 \mathrm{ft} / \mathrm{d}$ with an average of about $250 \mathrm{ft} / \mathrm{d}$.

\section{Determination from Pumping Test}

In an effort to evaluate the aquifer response to pumping stress, a pumping test was conducted May 11-12, 1982. An ideal aquifer test in a hydrogeologically complex area such as this would require the installation of several wells, but for economy, this test was designed for only two wells. Suffolk County Water Authority we11 S57357 was used for the production we11, and wel1 S72419 was installed with a continuous water-1evel recorder to monitor water levels during the test.

Geologic setting.--The pumping-test site, north of Ditch Plains near Lake Montauk, is geologically representative of most of the Montauk area; a driller's $\log$ and gamma ray $\log$ are shown in figure 20. The aquifer at this site is $88 \mathrm{ft}$ thick and consists mainly of fine to coarse sand and gravel. Beneath it, at about $103 \mathrm{ft}$ below sea level, is the marine clay unit, which consists mostly of clay with some interbedded silt. The overlying till unit is approximately $45 \mathrm{ft}$ thick and extends from near land surface to about $15 \mathrm{ft}$ below sea level.

Wel1 construction.--The production well was drilled by cable-tool method to a total depth of $143 \mathrm{ft}$ below land surface and completed by removing casing until $60 \mathrm{ft}$ of 10 -inch casing remained; $31 \mathrm{ft}$ of screen was installed at the bottom. The screened interval is from 60 to $91 \mathrm{ft}$ below land surface (28 to $59 \mathrm{ft}$ below sea leve1). The well is pumped by a submersible pump rated at 300 gal/min capacity.

The observation well was drilled $52 \mathrm{ft}$ east of the production we 11 by an auger dril1 rig. The well is constructed of $60 \mathrm{ft}$ of 2 -inch-diameter steel casing with $5 \mathrm{ft}$ of screen at the bottom. The screened zone is set at 60 to $65 \mathrm{ft}$ below land surface ( 28 to $33 \mathrm{ft}$ below sea level).

Procedures and observations.--The production well was pumped for 12 hours on May 11, 1982, at $285 \mathrm{gal} / \mathrm{min}$. Drawdown in the observation we 11 was continuously monitored by a water-stage recorder and an electronic waterlevel-sensing device. Water pumped from the well was discharged into the Suffolk County Water Authority distribution system. Minor changes in the 
system pressure caused the pumping rate to fluctuate between 250 and 300 $\mathrm{gal} / \mathrm{min}$. After 12 hours, the pump was stopped, and recovery data were collected for 14 hours, at which time the recorder malfunctioned.

During April 26-28, 1.38 inches of rain fell, and trace amounts also fell on May 3, 4, and 9. On May 10, 0.07 inches of rain was measured at Bridgehampton, but the water level in the observation well showed no effect from this before the pumping test. No rain fell during the test nor during the period of recovery until after the recorder malfunctioned (National Oceanic and Atmospheric Administration, 1982).

Water samples were collected by the Suffolk County Water Authority for chloride measurement during the pumping test. At the start of the test, chloride concentration was $31 \mathrm{mg} / \mathrm{L}$ but gradually rose over the next 12 hours to $60 \mathrm{mg} / \mathrm{L}$ just before pump shutdown. This rate of increase clearly indicates that the interface is sensitive to pumping at this site.

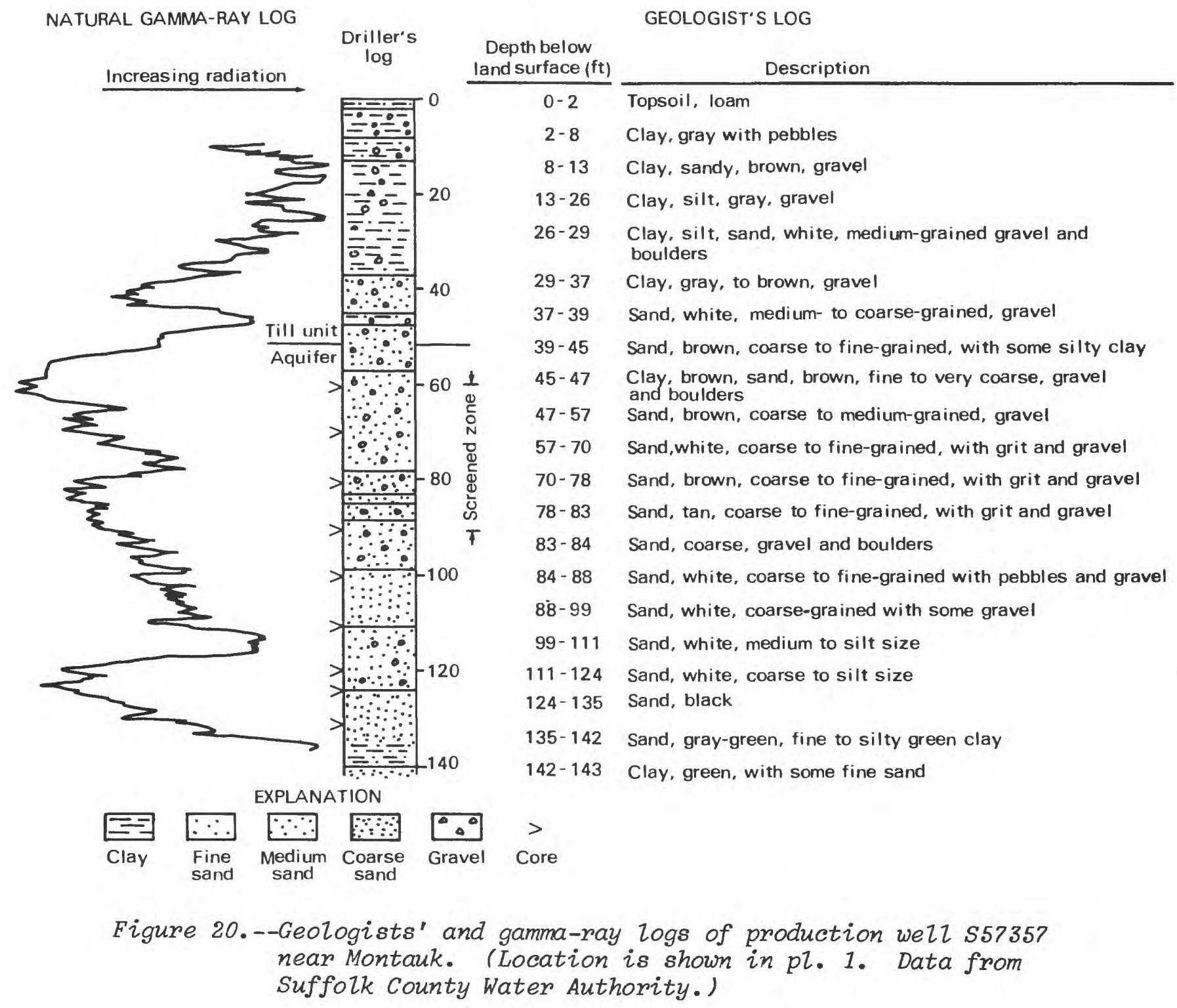


During the pumping test, the aquifer was found to be influenced by tidal fluctuations of about $0.2 \mathrm{ft}$, which required adjustment of drawdown and recovery data. Although no background or "noise" well was monitored during the test, water-level records collected at the observation well after the pumping test provided a reasonable estimate of the tidal influence. Drawdown and recovery data were then adjusted by comparison with average measured tidal influence and tidal records (National Oceanic and Atmospheric Administration, oral commun., 1982). Plots of the drawdown and recovery indicate a small amount of tidal influence even after the adjustment. Drawdown and recovery data, including the adjusted values, are listed in table 7. Pumping-test results were then analyzed through graphic and numerical modeling methods, as described below.

Graphic analysis.--Many techniques are available for analysis of data from aquifer-pumping tests, each with individual merits and simplifying assumptions. The main advantage of the graphic technique is the ease with which it can be done. Results of the graphic technique can be used as

Table 7.--Drowdown and recovery data from 12-hour pumping test, May 11-12, 1982.

\begin{tabular}{|c|c|c|c|c|c|}
\hline \multirow{2}{*}{$\begin{array}{l}\text { Time since } \\
\text { start of } \\
\text { pumping } \\
\text { (min.) } \\
\end{array}$} & \multicolumn{2}{|c|}{ Drawdown ( $f t)$} & \multirow{2}{*}{$\begin{array}{c}\text { Time since } \\
\text { end of } \\
\text { pumping } \\
\text { (min.) }\end{array}$} & \multicolumn{2}{|c|}{ Recovery ( $f t$ ) } \\
\hline & Observed & Corrected 1 & & Observed & Corrected 1 \\
\hline 0.5 & 0.34 & 0.35 & 1.0 & .41 & .41 \\
\hline 1.0 & .44 & .44 & 1.5 & .46 & .46 \\
\hline 1.5 & .49 & .49 & 2.5 & .51 & .51 \\
\hline 2 & .52 & .52 & 3.5 & .54 & .54 \\
\hline 3 & .56 & .56 & 5.5 & .57 & .57 \\
\hline 5 & .59 & .59 & 10 & .62 & .62 \\
\hline 15 & .64 & .65 & 20 & .65 & .65 \\
\hline 20 & .65 & .66 & 30 & .68 & .67 \\
\hline 30 & .67 & .69 & 45 & .72 & .69 \\
\hline 45 & .67 & .69 & 60 & .75 & .71 \\
\hline 60 & .67 & .70 & 75 & .77 & .72 \\
\hline 75 & .67 & .70 & 90 & .79 & .73 \\
\hline 90 & .68 & .72 & 105 & .81 & .74 \\
\hline 105 & .69 & .73 & 120 & .83 & .75 \\
\hline 120 & .70 & .75 & 150 & .85 & .76 \\
\hline 150 & .70 & .77 & 180 & .88 & .78 \\
\hline 180 & .70 & .81 & 210 & .89 & .79 \\
\hline 210 & .71 & .83 & 240 & .90 & .82 \\
\hline 240 & .72 & .83 & 300 & .91 & .87 \\
\hline 300 & .75 & .82 & 360 & .90 & .90 \\
\hline 360 & .76 & .79 & 420 & .88 & .92 \\
\hline 420 & .81 & .81 & 480 & .86 & .92 \\
\hline 480 & .83 & .80 & 540 & .84 & .92 \\
\hline 540 & .87 & .82 & 600 & .82 & .88 \\
\hline 600 & .88 & .83 & 660 & .83 & .85 \\
\hline 660 & .86 & .83 & & & \\
\hline
\end{tabular}


starting values in numerical-model analysis, which saves time in trial-anderror estimates of aquifer properties ranging over several orders of magnitude.

The graphic method of pumping-test analysis that best fit the data was the Hantush-Jacob Method for leaky confined aquifers as outlined in Lohman (1972). This method allows the computation of transmissivity, storage coefficient, and vertical hydraulic conductivity of the confining bed. Tnherent in this technique are the assumptions that the aquifer is infinite and isotropic and that the well fully penetrates the aquifer-assumptions that were not met in this test.

The graphic analysis yielded an aquifer transmissivity value of 23,700 $\mathrm{ft}^{2} / \mathrm{d}$, which is equivalent to a hydraulic conductivity of $270 \mathrm{ft} / \mathrm{d}$. The storage coefficient was $1.1 \times 10^{-3}$, and the total vertical hydraulic conductivity of the confining layers was $17.5 \mathrm{ft} / \mathrm{d}$. These values are only approximate because (1) aquifer response was observed at only one point, and (2) the tidal fluctuations affected the drawdown data.

An analysis of this kind gives no unique solution inasmuch as the matching of drawdown curves with type curves is somewhat discretionary and because the basic assumptions of the analysis were not met. The marine clay unit was assumed to be an impermeable boundary in this test, but in reality it is not, and not all water derived from the confining beds is obtained from the overlying till unit; some water may come from the lower marine clay unit. In addition, the transient response of the confining beds further violates the basic assumptions of this technique. The method of estimating leakage from the confining beds assumes that the only source of water to the aquifer is leakage through the confining beds, but some water can be released from storage from the confining layers during the test as the hydraulic gradient through the confining layers adjusts to the decline in head. For these reasons, the value of $17.5 \mathrm{ft} / \mathrm{d}$ for hydraulic conductivity of the confining layer is probably too large. However, the estimated values of hydraulic conductivity and storage coefficient of the aquifer are within a reasonable range despite their departure from values previously published in the literature for Long Island.

\section{Numerical-Model Analysis of Pumping Test}

The pumping test, as designed, violates many of the basic assumptions necessary for use of the graphic technique. Analysis of the pumping test by a numerical model enables better duplication of the aquifer properties, well and screen location, and aquifer response, as explained in the model description below.

Numerical-model analysis of the pumping test is not limited to the drawdown part of the well response, where variation in pumping rate can have an adverse affect on data analysis; it allows simulation of both the pumping and recovery parts of the test. It also can provide more information about the aquifer properties than some of the other techniques. Numerical-model analysis, which incorporates a detalled knowledge of the geologic environment, can provide estimates of horizontal and vertical hydraulic conductivity of the principal aquifer, vertical hydraulic conductivity of the confining unit, and storage coefficient and specific yield of both the aquifer and confining unit. 
Description of mode1.--From the hydraulic-conductivity values obtained in the graphic analysis of pumping-test data, a transient-state Galerkin finite-element flow model developed by Reilly (1981) was used to simulate both drawdown and recovery curves obtained during the test. This model was chosen because it simulates ground-water flow through a representative vertical cross section of aquifer that is radially symmetric around the axis of a pumping we11. The model is capable of simulating hydraulic response to pumping in an aquifer that is not homogeneous, regardless of we11-screen penetration, provided the aquifer is radially symmetric. Horizontal and vertical hydraulic conductivity can vary within the model, although they are constant within a single model element. Simulation of the major layers of an aquifer and of confining units is possible with this model. A simplified cross section of the modeled pumping-test area is shown in figure $21 \mathrm{~A}$, and the model grid representing the cross section is shown in figure 21B. Some of the assumptions and restrictions inherent in this model are:

1) Specific yield and specific storage are constant over the entire grid;

2) the well has no seepage face:

3) the free surface of the aquifer (water table) does not move;

4) the aquifer extent is finite (a constant-potential boundary was established $10,000 \mathrm{ft}$ from the well);

5) the pumping rate is constant; and

6) the saltwater interface is not simulated.

The pumping test was simulated on a 181-node, 308-element grid depicted in figure $21 \mathrm{~B}$. The area modeled extends from the pumping well to a point $10,000 \mathrm{ft}$ distant, at which no measurable drawdown was expected to occur during the test. Two units were modeled--a 50-ft thickness of saturated confining unit composed of undifferentiated deposits of till and stratified drift overlying the aquifer, and the aquifer itself, $85 \mathrm{ft}$ thick. The underlying marine clay was assumed not to yield water to the well during the 12-hour test and was therefore modeled as a no-flow boundary. The principal aquifer and the overlying confining unit were modeled as homogeneous layers of uniform thickness.

Mode1 calibration.--The method used to determine the hydraulic conductivity and storage coefficient with the model was a trial-and-error technique. Initial values of the variables were based upon the graphical analysis of pumping-test data and the hydraulic conductivity estimates derived from specific-capacity data. Sensitivity tests were then run on the selected variables to reveal which ones affected the drawdown most severely. Some variables had a greater effect in the early part of the test than later, and vice versa. For example, changing the storage coefficient of the aquifer had a much greater effect on the early part of the drawdown curve than on the later part. Inspection of the various sensitivity plots revealed which aquifer values needed adjustment to approximate the observed drawdown curve at the observation well. Inspection also confirmed that the drawdown predicted by the model was relatively insensitive to specific yield and radial hydraulic conductivity of the overlying confining bed, which made the estimates for these characteristics invalid.

After calibration of the model from drawdown data, a simulation of the recovery phase was attempted. Recovery was not simulated as well as drawdown, so additional adjustments to the specified aquifer properties were made. This 

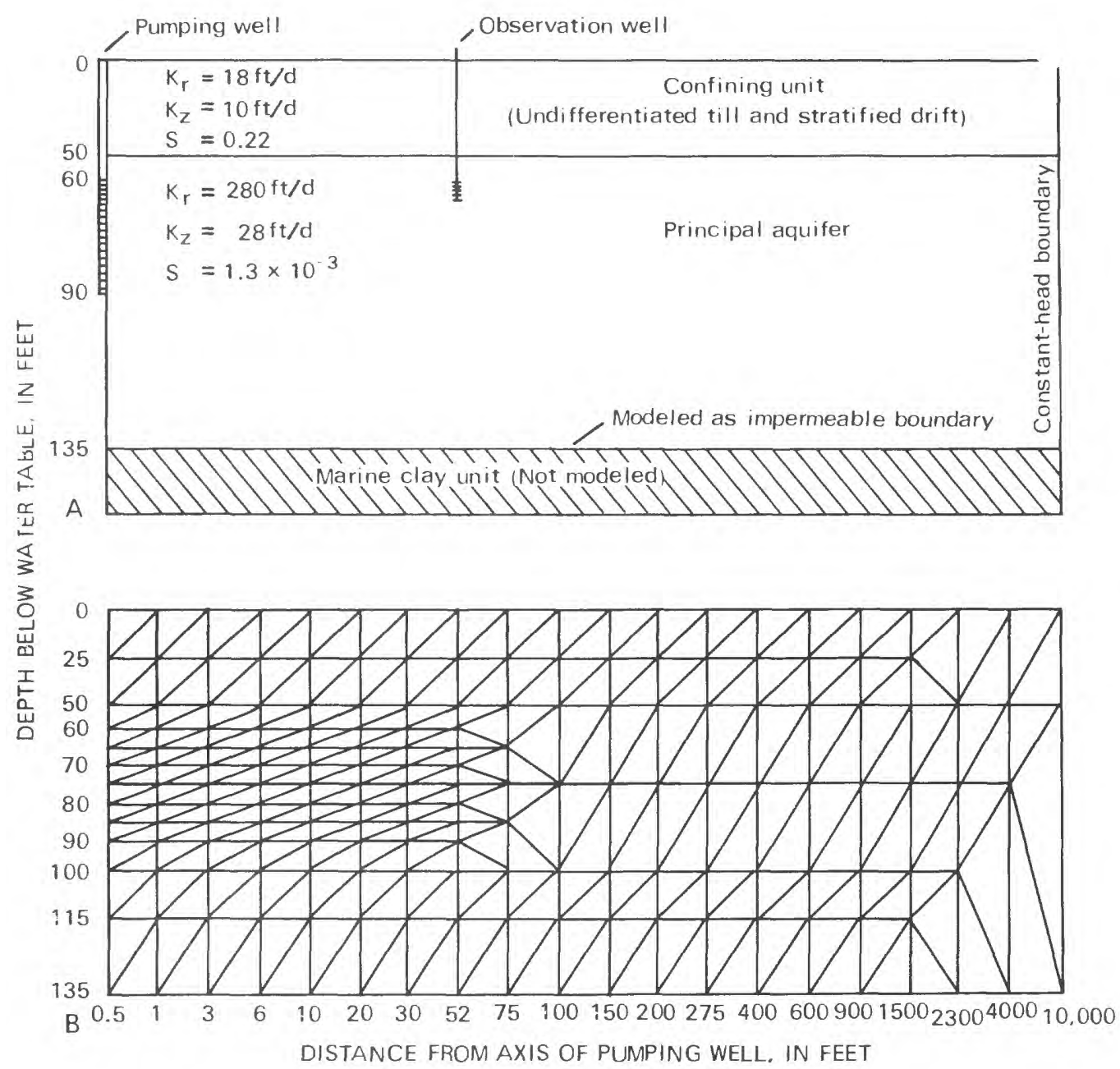

Eigure 21.--Generalized hydrogeologic section of modeled pumping-test site: A. Major units and initial values of radial $\left(K_{r}\right)$ and vertical $\left(K_{2}\right)$ hydraulic conductivity and storage coefficient $(S)$.

B. Finite-element grid over same area.

improved the recovery simulation slightly but adversely affected the drawdown simulation. A comparison of observed and simulated drawdown and recovery curves is given in figure 22 .

The simulated drawdown data match the observed data fairly well over most of the test; however, some cyclical variability in the observed heads is evident in the late part of the test, even after correction for tidal fluctuation. The simulated recovery data show a close match in the early part of the test but depart significantly from the observed data after about 120 minutes. The hydraulic values used in the final model run, shown in figure 22 , are listed in table 8. Results of the pumping-test analysis must be viewed on1y as rough approximations of aquifer values because the aquifer response was observed at only one location; more reliable estimates could be obtained by monitoring the response at several depths, directions, and distances from the pumping well. 
The lack of sensitivity of predicted heads to both radial hydraulic conductivity and specific yield of the till unit indicates that values of these factors are not unique and may be in error.

Other errors in analysis may result from (1) the simplification of the aquifer system, (2) the Inability of the model to simulate movement of the saltwater interface, (3) unavoidable variations in the pumping rate during the pumping test, and (4) the effects of tidal influences on observed water levels. The values obtained in this pumping test apply to one location only; their degree of variation throughout the Montauk area is unknown.
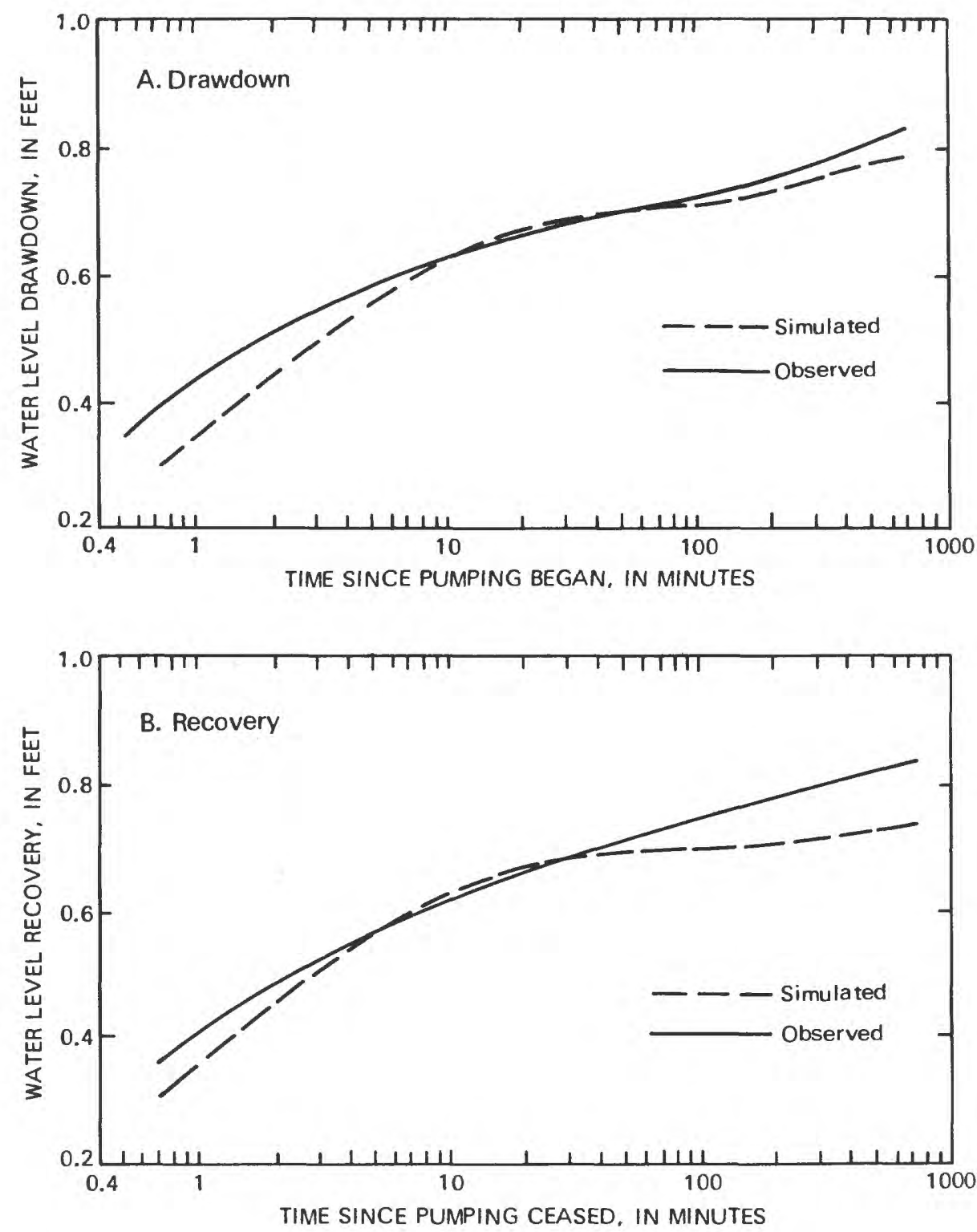

Figure 22.--Observed and simulated water levels at observation well $52 \mathrm{ft}$ from production well during pumping test at Montauk, May 11-12, 1982. A. Drowdown. B. Recovery. 
Table 8.--Hydraulic values used in simulation of pumping-test drawdown and recovery.

\begin{tabular}{lcc}
\hline $\begin{array}{c}\text { Aquifer } \\
\text { characteristic }\end{array}$ & $\begin{array}{c}\text { Overlying confining layer } \\
\text { (undifferentiated deposits of } \\
\text { till and stratified drift) }\end{array}$ & $\begin{array}{c}\text { Principal } \\
\text { aquifer }\end{array}$ \\
\hline $\begin{array}{l}\text { Radial hydraulic } \\
\text { conductivity (ft/d) }\end{array}$ & $* 100$ & 280 \\
$\begin{array}{l}\text { Vertical hydraulic } \\
\text { conductivity (ft/d) }\end{array}$ & 15 & 90 \\
$\begin{array}{l}\text { Specific yield } \\
\text { Storage coefficient }\end{array}$ & $* 0.15$ & $2.2 \times 10^{-3}$ \\
\hline
\end{tabular}

* Variation of this factor had little effect on predicted heads at the observation well and thus may be in error by orders of magnitude.

The hydraulic values obtained in the specific-capacity-test data agree with those obtained from the graphical analysis and numerical model analysis of the pumping test and also with published data, as indicated by the comparisons in table 9. Hydraulic-conductivity values are within the published range for the south fork; anisotropy values and storage coefficients, although not within this range, are within the published range for other areas on Long Island. Although some of the values obtained in the analyses previously discussed show some variability, they were similar enough to provide initial aquifer values for an areal flow model of the Montauk area.

Table 9.--Comparison of hydraulic values obtained from four sources.

\begin{tabular}{|c|c|c|c|c|}
\hline $\begin{array}{l}\text { Aquifer } \\
\text { characteristics }\end{array}$ & $\begin{array}{l}\text { Specific- } \\
\text { capacity } \\
\text { test data }\end{array}$ & $\begin{array}{l}\text { Aquifer-test } \\
\text { graphical } \\
\text { analysis }\end{array}$ & $\begin{array}{l}\text { Aquifer-test } \\
\text { numerical } \\
\text { simulation }\end{array}$ & $\begin{array}{l}\text { South fork } \\
\text { literature }\end{array}$ \\
\hline $\begin{array}{l}\text { Horizontal hydraulic } \\
\text { conductivity (ft/d) }\end{array}$ & $130-350$ & 270 & 280 & $\begin{aligned} a_{43} & -435 \\
b_{2} 200 & -750\end{aligned}$ \\
\hline $\begin{array}{l}\text { Anistropy (ratio } \\
\text { of horizontal to } \\
\text { vertical conductivity) }\end{array}$ & c & $1: 1$ & $3: 1$ & $\mathrm{~b}_{10: 1-100: 1}$ \\
\hline Aquifer storativity & $f$ & $d_{1.1} \times 10^{-3}$ & $\mathrm{~d}_{2} .2 \times 10^{-3}$ & b,e. $20-.30$ \\
\hline
\end{tabular}

a Fetter, 1971.

b Nemickas and Koszalka, 1982.

c Assumes isotropic aquifer medium.

d Storage coefficient for confined area of principal aquifer.

e Specific yield for unconfined area of principal aquifer.

$f$ Cannot be estimated by this method. 


\section{DEVELOPMENT OF MONTAUK REGIONAL FLOW MODEL}

Ground water in the Montauk area is in constant movement from areas of recharge to natural and man-induced discharge points. The movement of ground water is dependent upon the thickness and horizontal and vertical hydraulic conductivity of the aquifers and confining units, the location of streams and ponds, variations in recharge, and manmade stresses such as ground-water pumping. The response of the ground-water system to variations in these factors can be examined through use of simulation models. A ground-water model is a simplified representation of the boundary conditions, internal geometry, and hydraulic characteristics of the natural system. If these factors are accurately represented, and a given change in recharge or pumpage is applied, the model will simulate the changes in hydraulic head throughout the ground-water system.

\section{Model Design}

A finite-difference model capable of simulating areal flow of both saltwater and freshwater was selected for this study because the saltwater interface plays a major role in this system. Numerical development and computer code documentation is presented in Mercer, Larson, and Faust (1980); minor modifications were made to allow areal variability of recharge rates and simulation of both water-table and confined conditions, depending upon the potentiometric surface and the altitude of the bottom of the overlying confining bed. The model is based upon the Dupuit assumption that equipotential lines are vertical throughout the aquifer, the interface between freshwater and saltwater is sharp, and ground-water flow is simulated in two dimensions horizontally.

Simulation of the ground-water flow system with a finite-difference model requires the division of the aquifer system, at an appropriate scale, into discrete grid blocks. Aquifer-boundary conditions, initial conditions, and average values for aquifer characteristics are assigned to each block according to conditions within that block in the natural system. Selection of an appropriate grid scale is related to two factors--the size of the entire flow system, and the detail required in the response of the model. This study, which sought the regional response to stress on the ground-water system, used a grid of 1,488 blocks, each 1,000 ft by 1,000 ft (fig. 23).

The data assigned to the model to simulate the ground-water flow system were: (1) system geometry, (2) boundary conditions, (3) horizontal hydraulic conductivity, (4) recharge rates, and (5) system stresses and their locations. These five hydrologic characteristics can be varied to fine tune or "calibrate" the flow model so that the model accurately simulates the natural system's response to stress; model calibration is discussed in detail in a later section of this report. Values for these five characteristics can of ten be estimated with some certainty; however, selection of representative boundary conditions is sometimes difficult.

Selection of appropriate boundaries can be simplified if the system's natural boundaries can be represented; but when model size or other factors make this impossible, arbitrary boundary conditions must be applied. These arbitrary boundaries have a direct effect upon the model's results, and 
understanding how the model represents the natural system boundaries and in what way the boundaries constrain the results becomes necessary.

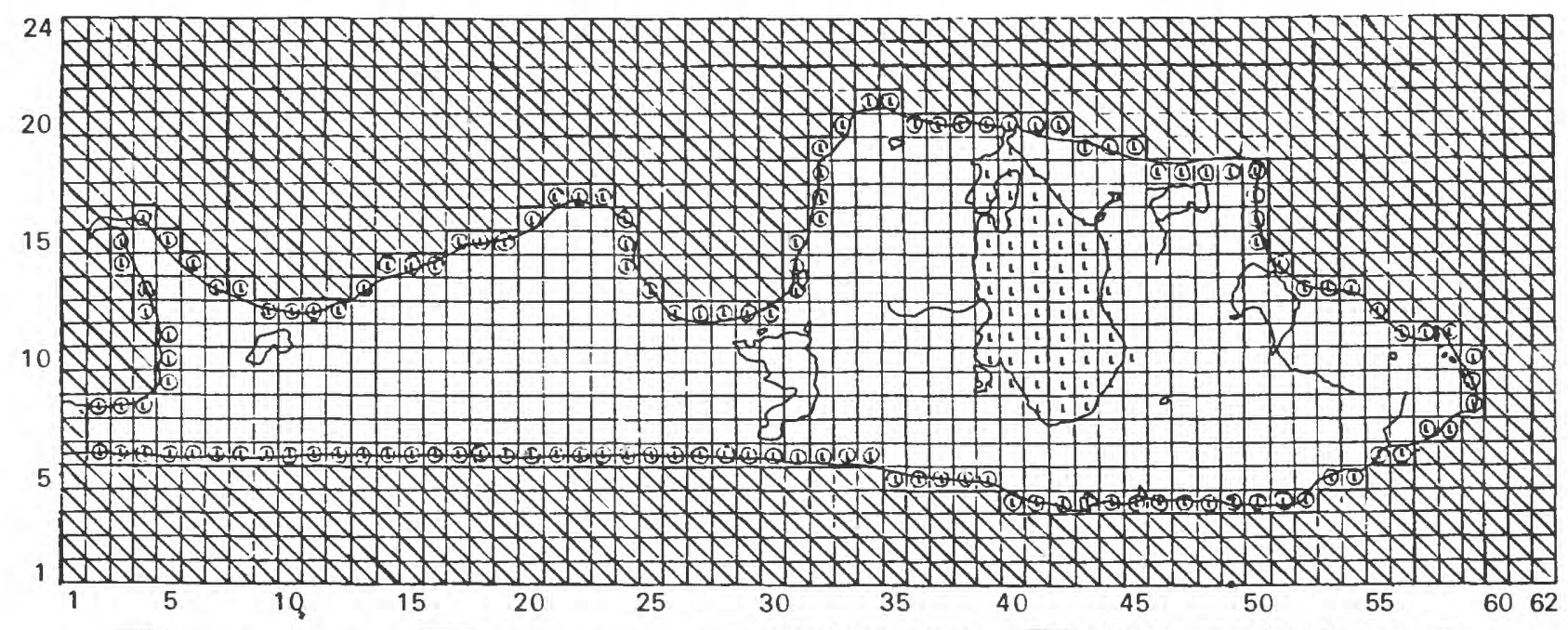

$\triangle$ Inactive block

$\square$ Active block

$L$ Head-dependent

(D) Head-dependent leakage and

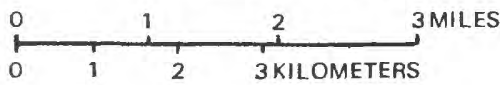

Figure 23.--Finite-difference grid for ground-water flow model of the Montauk area. Each node represents an area of 1,000 ft by 1,000 ft.

\section{Boundary Conditions}

The boundary conditions used to simulate ground-water flow in the Montauk model are a simplified representation of the natural aquifer boundaries, as explained below.

\section{Upper Boundary}

The upper boundary of the principal aquifer is represented as a constant-inflow boundary; inflow consists of recharge from precipitation or ground-water seepage from the overlying confining unit, where present. The overlying confining unit is only a minor water-bearing unit and is therefore not included in the saturated thickness of the mode1. Where the confining unit is at or beneath the potentiometric surface of the aquifer, the aquifer is simulated as confined; where the confining layer is above the potentiometric surface or absent, the aquifer is simulated with a free water-table surface.

\section{Lower Boundary}

The lower boundary of the aquifer is represented as an impermeable (no-flow) boundary that coincides with the surface of the marine clay unit (fig. 4). The clay unit is not included as part of the flow system because it has low permeability and probably transmits little water and also because little recoverable freshwater is present beneath it. 
Where the freshwater/saltwater interface is above the clay unit, its depth is calculated by the model, and transmissivities are adjusted accordingly.

\section{Lateral Boundary}

Freshwater in the principal aquifer moves laterally toward the shore, where it moves upward and discharges to tidewater through the floor of the ocean and bays. This discharge boundary is simulated as a head-dependent leakage boundary where flow is through a vertical conductance branch between the model node and the ocean floor. Discharge is dependent upon the hear at the node, the freshwater equivalent head at the ocean floor, and the hydralic conductance of the vertical flow path, as shown in figure 24 . The conuluctance term is expressed by:

$$
C=\frac{K^{\prime} A}{b^{\prime}}
$$

where: $C=$ conductance term;

$\mathrm{K}^{\prime}$ = vertical hydraulic conductivity from center of model block to discharge face, in $\mathrm{ft} / \mathrm{d}$;

$b^{\prime}=$ vertical distance from center of block to average dischargeface location, in $\mathrm{ft}$; and

$A=$ cross-sectional area through which flow is taking place $\left(\Delta \mathrm{x}^{\prime} \Delta \mathrm{y}\right)$, in $\mathrm{ft}^{2}$.

In positioning the model grid in relation to the Montauk area, an effort was made to align the block centers with the shore to accurately represent the discharge boundary.

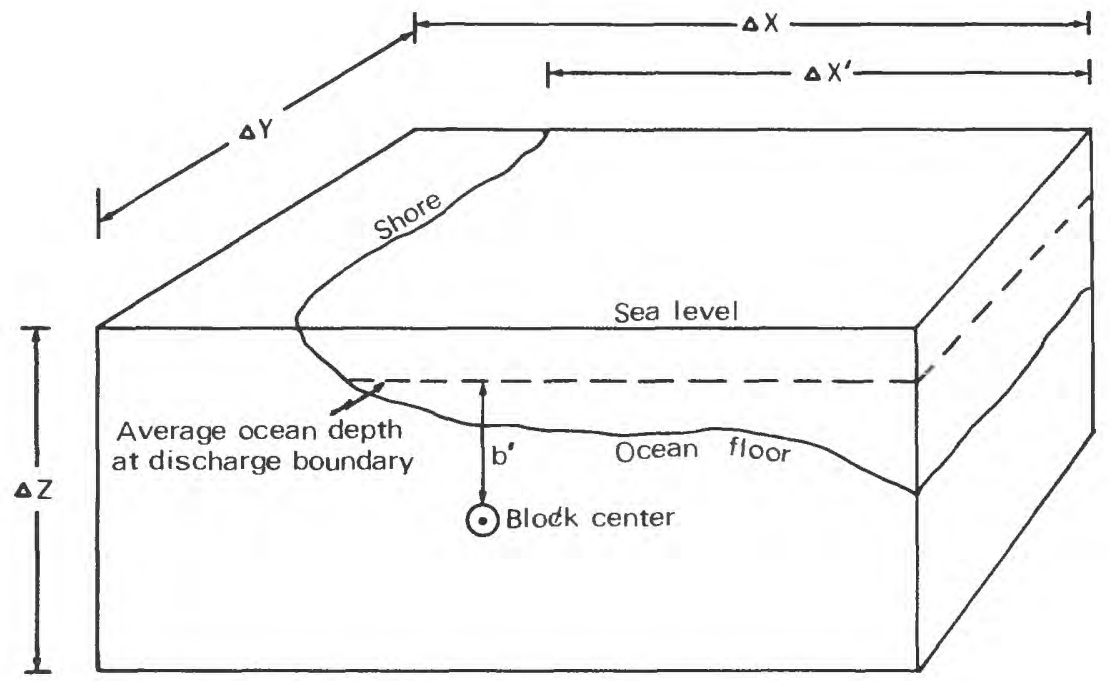

Figure 24.--Model representation of shoreline head-dependent leakage-boundary block. 
Little is known about the seepage through the ocean and bay floors, especially how far offshore it occurs. The model was originally designed to use several nodes for of fshore discharge to allow calibration of this distance through deletion of blocks as necessary. It was found that no more than one row of discharge blocks was needed, however.

The narrow strip of land at the west edge of the modeled area at Napeague is underlain by a thin freshwater lens in which flow is perpendicular to the shore. For this reason, flow between the Montauk area and the Napeague beach area was assumed minimal and was represented as a no-flow boundary.

\section{Fresh Surface-Water Bodies}

Depending upon local conditions, fresh surface-water bodies can be a source or a point of discharge from the ground-water system. The three types of surface-water features in the Montauk area were modeled as follows.

(1) Streamflow in the Montauk area is derived from overland runoff and from ground-water seepage from the till unit overlying the principal aquifer. Seepage to streams represents a loss of water from deposits overlying the principal aquifer, and this reduces the volume of water available to recharge the aquifer. Stream seepage is not included in the flow model, however, because it is not derived from the aquifer being modeled and because its effect upon recharge is negligible.

(2) Marshes are areas where the water table is exposed at land surface in the till unit. Although these areas cause a net loss of recharge through evapotranspiration, they are not simulated in the model.

(3) Major ponds in the Montauk area represent a set of continually changing hydrologic conditions as pond levels fluctuate in response to seasonal stress. For steady-state model simulations, a highly simplified method of representing the ponds was chosen--they were modeled as blocks of higher recharge on the assumption that their topographic drainage basins act as closed systems that collect and store precipitation, and that the only outflow is evapotranspiration and ground-water seepage to the principal aquifer beneath. The ponds are generally of higher hydraulic head than the aquifer; therefore, under average conditions, they recharge the principal aquifer at a rate that can be calculated by common water-budget techniques.

A water budget for four ponds in the area (table 10) was prepared from precipitation, streamflow, and evaporation data on the assumption of average steady-state flow conditions, as expressed by equation 5:

$$
\text { Recharge }=P+R-E
$$

where: Recharge = seepage to the aquifer,

$P=$ precipitation on the pond surface,

$R$ = direct runoff plus base flow of the tributary, and

$E$ = evaporation from the pond surface. 
Average annual precipitation used in the calculations was 42.54 inches, which was obtained by methods discussed in the earlier section "Recharge." Runoff was calculated by multiplying precipitation, topographic drainage-basin area, and an assumed direct runoff coefficient of 5 percent, plus average stream base flow where applicable. The resulting value of runoff is probably high, inasmuch as the runoff coefficient of 5 percent is greater than the 1 percent of precipitation calculated for gently sloping outwash deposits on Long Island's south shore by Franke and McClymonds (1972). Yet, the geologic and topographic environment of the Montauk area seems to justify the higher coefficient. Evaporation from the lake surface was estimated from pan evaporation at Greenport, on the north fork (fig. 1) (National Oceanic and Atmospheric Administration, 1972-81). Pan-evaporation values (table 3 ) were corrected for energy budget and aerodynamic factors by applying a coefficient of 0.7 (Linsley and others, 1975). The water-budget data for each pond are given in table 10 .

Table 10.-Water-budget summary for four major ponds in the Montauk area. [Pond locations are shown in fig. 2.]

\begin{tabular}{|c|c|c|c|c|}
\hline & $\begin{array}{l}\text { Fresh } \\
\text { Pond }\end{array}$ & $\begin{array}{l}\text { Fort } \\
\text { Pond }\end{array}$ & $\begin{array}{l}\text { Oyster } \\
\text { Pond }\end{array}$ & $\begin{array}{l}\text { Big Reed } \\
\text { Pond }\end{array}$ \\
\hline Water-surface area $\left(\mathrm{mi}^{2}\right)$ & 0.05 & 0.27 & 0.19 & 0.08 \\
\hline $\begin{array}{l}\text { Topographic drainage basin } \\
\text { area }\left(\mathrm{mi}^{2}\right)\end{array}$ & .78 & .77 & 1.9 & .48 \\
\hline $\begin{array}{l}\text { Precipitation volume }\left(\mathrm{ft}^{3} / \mathrm{s}\right) \\
\quad \text { (Precip. } \mathrm{x} \text { area) }\end{array}$ & .16 & .85 & .59 & .26 \\
\hline Basin runoff $\left(\mathrm{ft}^{3} / \mathrm{s}\right)$ & .12 & .12 & .30 & .08 \\
\hline Base flow $\left(\mathrm{ft}^{3} / \mathrm{s}\right)$ & 0 & 0 & .20 & 0 \\
\hline Evaporation $\left(\mathrm{ft}^{3} / \mathrm{s}\right)$ & -.08 & -.39 & -.27 & -.12 \\
\hline Recharge $\left(\mathrm{ft}^{3} / \mathrm{s}\right)$ & .2 & .58 & .83 & .21 \\
\hline
\end{tabular}

Analysis of these water budgets entails the simplifying assumptions that (1) average steady-state flow conditions prevail; (2) inflow consists only of precipitation on the pond surface and direct runoff from the topographic basin; and (3) outflow consists only of evaporation from the pond surface and seepage to the underlying aquifer.

The water budget for Oyster Pond is complicated because, during heavy storms, sea water breaks through the berm separating the pond from the ocean and mixes with the pond water. In time, the ocean currents and littoral drift reestablish the berm, and the pond once again fills with freshwater. This exchange occurs once or twice annually, making the water in Oyster Pond impotable because of high concentrations of chloride. Perlmutter and DeLuca (1963) reported chloride concentrations ranging from 10,000 to $13,500 \mathrm{mg} / \mathrm{L}$.

For modeling purposes, the water budget of Oyster Pond was modified on the assumption that (1) the pond is open to the ocean once a year, at which time 1 foot of freshwater is lost to the ocean, and (2) the berm reestablishes itself quickly so that the long-term effect upon the ground-water system is only to lower the average recharge rate to the principal aquifer. 
In reality, this is an oversimplification, and, in addition to the variability of aquifer recharge due to the breeching of the berm, the water quality is significantly altered. The water budget of Oyster Pond and its effect on the principal aquifer could be the subject of a separate detailed study. Inaccuracies caused by this simplified representation are assumed to be minimal, however, because the pumping stresses to be investigated are far from the pond, and the pond is close to a natural discharge boundary.

The relationship between the lakes and the aquifer is constantly changing seasonally and in response to other stresses. During summer, when precipitation is low and evapotranspiration high, lake levels can drop below the potentiometric surface of the aquifer, whereas during winter, when precipitation is high and evapotranspiration low, lake levels may rise above it. Although the dynamic relationship between the lakes and the aquifer is difficult to assess, the average water-budget technique was considered adequate for simulating equilibrium conditions.

\section{Model Calibration and Sensitivity Analysis}

Initial values for various hydrologic coefficients in a ground-water flow model are based on the results of pumping-test analyses and published values for the area under investigation. The use of average values obtained from these sources may lead to error, however, owing to the heterogeneity and local variability of most aquifer systems.

To overcome this potential for error, initial estimates of hydrologic coefficients are used to calculate head values and saltwater-interface positions, and these are then compared to the measured field values. If the model does not accurately reproduce the field measurements, the hydrologic coefficients must be reevaluated and adjusted until an acceptable match between field data and model results is achieved. This process of "tuning" the hydrologic coefficients is known as model calibration.

To confirm that the calibration match is not coincidental, the model should be checked against a different set of hydrologic conditions and the results compared to the corresponding field measurements. This second process is known as model verification, or acceptance. Model calibration and verification are discussed in detail by Konikow (1978).

A proper calibration process includes a sensitivity analysis of the various hydrologic coefficients to reveal which factors have the most influence upon the model solution. The sensitivity analysis is done by individually varying each hydrologic coefficient over an expected range of values and comparing results with field data until an acceptable match is achieved. Some factors can influence different parts of the modeled system to differing degrees. For instance, changes in values of the conductance term for the head-dependent leakage-boundary in the Montauk model alter groundwater head gradients near the shore much more than in the central area.

The Montauk model was calibrated for steady-state average water levels and recharge. Normally a steady-state calibration requires long-term records of water-level data from which average conditions can be estimated. The 
Montauk area, however, contains few wells with records that exceed a few years; the longest record is only 8 years. Hydrographs of the five wells with 6 to 8 years of records ( $\mathrm{fig} .10$, p. 21 ) were examined to obtain a long-term average water level; it was found that March and April 1982 water levels (dasted lines in fig. 10) represented near-average water levels in these and several other wells in the area. Although the potentiometric-surface map (fig. 9) drawn from these data does not represent steady-state conditions in al1 areas, it is an acceptable approximation for calibration purposes.

In the absence of specific data on the areal distribution of hydrologic coefficients, uniform average estimates of recharge and hydraulic conductivity were used. Recharge was applied uniformly to the model at a rate of 21.3 in/yr, which is 50 percent of the estimated long-term average precipitation for the Montauk area. The reason for uniform distribution was that factors controlling recharge to the principal aquifer, such as evapotranspiration, confining beds, and surface runoff vary locally, making their effects on recharge too complex to quantify on a block-by-block basis.

In addition to natural recharge from precipitation, a quantity of water was added to account for recharge from cesspools--that is, nonconsumptive ground-water use. In the model calibration, this was estimated and applied as follows: (1) average daily pumping rates at each Suffolk County Water Authority well field and at other major pumping centers (table 4) were calculated from annual pumpage reported during 1977-81; (2) these pumping rates were applied to the model at the nodes corresponding to the location of each we11; (3) after an assumed 15 percent of the pumpage was subtracted for consumptive use, the remainder, which represents recharge from cesspools, was reapplied over the appropriate area. Thus, for the Suffolk County Water Authority, 85 percent of the total pumpage was uniformly reapplied to the area served by their distribution system. In areas served by individual wells, pumpage and consumptive use were assumed negligible because these areas are generally developed at low density and were therefore not applied to the model.

In calibrating the model, refinement efforts were focused on three system components--aquifer geometry, hydraulic conductivity, and boundary seepage. Aquifer geometry was varied slightly during calibration to assess the effects of inaccuracy due to discretization error. Hydraulic conductivity was varfed because model resuits are sensitive to variations in this aquifer characteristic. The combined term for head-dependent shoreline leakage was varied to refine heads and gradients near the shore. Each of these factors is described in detail below.

\section{Aquifer Geometry}

Aquifer geometry was altered in a few calibration runs to assess the sensitivity of the model to possible inaccuracies where data were lacking and where shoreline approximation was poor.

The saturated freshwater thickness of the model was defined as the distance between the top of the marine clay unit and the bottom of the till unit overlying the aquifer except where the saltwater interface lies above the clay unit or where the potentiometric surface of the principal aquifer is below the overlying till unit. Because the altitudes of these surfaces are 
only approximately known, they were varied by as much as 10 percent in the model in areas where data were sparse. Results showed the model response to be only slightly sensitive to changes in freshwater thickness and to be less sensitive to the altitude of the marine clay unit than to that of the till unit. The model's relative insensitivity to the altitude of the marine clay unit is due to the position of the saltwater interface, which may be above the clay unit in some places. Because aquifer-transmissivity values are calculated from the thickness of freshwater between the till unit (or water table) and the interface, the marine clay altitude rarely enters into the calculations. Neither small changes in the altitude of the marine clay nor of the till unit introduced large errors in model results.

The uniform $1,000-\mathrm{ft}$ by $1,000-\mathrm{ft}$ block scale of the model results in some error along the irregular shores. The effects of this error were investigated by adding active grid blocks and relocating head-dependent leakage nodes. It was found that adding active aquifer blocks to the model by moving headdependent leakage nodes seaward by one block caused changes of less than 0.1 $\mathrm{ft}$ in the maximum predicted freshwater heads.

The final aquifer geometry differed little from its original form. Adjustment of the marine-clay unit altitude and the overlying till-unit altitude changed the aquifer thickness no more than $10 \mathrm{ft}$, and only a few boundary leakage nodes and active grid blocks were moved. These small changes did, however, cause minor changes in predicted freshwater heads and improved the match between simulated water levels and those measured in March-April 1982.

\section{Hydraulic Conductivity}

Model calibration of ten centers upon adjustment of hydraulic conductivity, an aquifer characteristic that can have wide local variations and major effects on hydraulic heads. Initial hydraulic conductivity was estimated from the aquifer-test data, specific-capacity data, and drillers' logs in the Montauk area. Sensitivity analysis showed a direct nonlinear relationship between hydraulic conductivity and predicted freshwater heads. The nonlinearity is attributed to boundary movement at the freshwater/saltwater interface. A range of hydraulic-conductivity values was tested, both with uniform distribution and with local variations. In most areas the initial estimates were too high, probably because they were based upon specific-capacity data from public-supply wells, which are generally screened in coarse, highly conductive aquifer material. Hydraulic-conductivity values investigated during calibration ranged from 190 to $350 \mathrm{ft} / \mathrm{d}$, and a final uniform value of $220 \mathrm{ft} / \mathrm{d}$ was selected. Although application of a uniform value does not reflect the local variability of the natural system, this approach was used because definitive field data were unavailable. Furthermore, the distribution of hydraulic conductivity within the system probably varies within a range similar to that which was tested, with a mean near the uniform value of $220 \mathrm{ft} / \mathrm{d}$.

\section{Head-Dependent Boundary Leakage}

The rate of discharge at model shoreline boundaries is controlled by two factors--the relationship between the hydraulic head in the aquifer and the freshwater equivalent head of the overlying saltwater at the ocean floor, and 
the hydraulic conductance of the leakage term. The freshwater equivalent head was calculated as the freshwater head needed to balance the saltwater column from sea level to the ocean floor at the discharge node as determined by ocean and bay bathymetry. A value of $0.25 \mathrm{ft}$ of freshwater head was selected for all shoreline discharge nodes representing an average depth of $10 \mathrm{ft}$ below sea level. In Lake Montauk, $0.13 \mathrm{ft}$ was used to represent an average depth of about $5 \mathrm{ft}$ because the lake is shallow. Sensitivity of the model to variations in these values was exceedingly small, so calibration of this factor was not pursued.

Characteristics of the shoreline discharge boundary have not been systematically investigated; thus, little is known about its variability. For this reason, the conductance term for head-dependent leakage, $\mathrm{K} / \mathrm{b}^{\prime}$, is applied somewhat arbitrarily. Sensitivity analysis has shown that model response to variations in the conductance term is nonlinear. Calculated freshwater heads in the model are almost totally insensitive to this term when its value exceeds about 1.0 , but when its value is decreased to around 0.05 , calculated freshwater heads are affected to an increasing degree.

Values for the conductance term were those just at the point where the model heads first become sensitive. Results showed, however, that correct simulation of calculated freshwater heads required considerable areal variability in the conductance term. In general, the conductance term was assigned lower values in areas where the till unit could be inhibiting offshore discharge. The conductance term has the greatest effect on the freshwater heads close to the shore, so adjustments were made by comparing model-generated gradients near the shore with field values. Final values for the conductance term ranged from 0.008 to 0.05 , which represents a vertical hydraulic conductivity $\left(K^{\prime}\right)$ of 0.4 to $2.5 \mathrm{ft} / \mathrm{d}$.

\section{Calibration Results}

Final calibration was considered complete when an acceptable match between the model-generated potentiometric surface and measured water levels of March-April 1982 was achieved.

Potentiometric surface.--A comparison of model-generated values and the measured potentiometric surface of March-April 1982 (fig. 25) shows a maximum head difference of about $0.7 \mathrm{ft}$. Differences between the model results and field values can be attributed to incomplete understanding of field conditions in certain areas and the nonequilibrium nature of the freshwater system, as discussed below.

Although the five well hydrographs in figure 10 show the water levels of March-April 1982 to be near average, the ground-water flow system is not in perfect equilibrium because recharge is intermittent, and pumpage irregular. As a result, subsurface outflow to the bays and ocean fluctuates and in turn causes the freshwater/saltwater interface to shift. Discrepancies between the steady-state model heads and the field values are greatest in two locations-the central part of the ground-water mound between Fort Pond and Lake Montauk, and the extreme eastern ground-water mound near Montauk Point (fig. 25). 
In the central part of the middle ground-water mound, the simulated 3-ft contour has a somewhat larger area than the measured one. Although it is not evident in the contoured potentiometric surface, a minor head depression is predicted that results from higher-than-average pumping rates at the Suffolk County Water Authority well fields. The actual pumping rates in the spring of 1982 were considerably lower than the annual average because the vacation season had not yet begun.

In the extreme eastern part of Montauk (fig. 25), the observed water levels are lower than the predicted levels. This discrepancy is due to the lack of data on altitude of the marine clay unit and the overlying confining unit and on the areal extent of the glacial clay in the Prospect Hill area. The aquifer thickness may be somewhat greater than the field data indicate, which causes aquifer transmissivity to be somewhat greater than that represented by the model.

The western part of Hither Hills also shows discrepancies between model results and field data; these are attributed to the lack of geologic data in that area. The few field data available seem to indicate the possibility of clay lenses or confining layers in this area, especially north of Fresh Pond, where the gradients become quite large. If these lenses or confining layers are present, they would reduce outflow to the ocean at the shores and thereby cause the elevated freshwater heads observed in the area.

Freshwater/saltwater interface.--A comparison between measured and predicted freshwater/saltwater-interface altitudes (fig. 26) shows a fairly close match. The model, as mentioned previously, is based on the assumption that equipotential lines in the aquifer are vertical (the Dupuit assumption). This aquifer contains some degree of anisotropy and local variability in hydraulic conductivity, however, which causes the equipotential lines to be nonvertical in places. This in turn may cause error in predicted interface altitudes. Other discrepancies between the predicted and observed altitude of the saltwater interface arise from the paucity of data points and, again, the nonequilibrium state of the ground-water system.

The shaded area in figure 26 is where the model predicts freshwater throughout the aquifer thickness. In this area, the marine clay unit (modeled as an impermeable bottom of the aquifer) is not deeper than $100 \mathrm{ft}$ below sea leve1. The maximum depth at which the model can predict the interface to occur is at the impermeable bottom of the modeled aquifer. Although the -100 $\mathrm{ft}$ contour predicted by the model deviates considerably from the observed -100 $\mathrm{ft}$ contour on the base of freshwater, the difference is insignificant in terms of obtainable freshwater quantity because freshwater within the marine clay unit cannot be extracted for water supply and should not be considered recoverable. Thus, the model results may be considered accurate.

A shortcoming in this model representation is that it ignores the possibility of saltwater upconing through the marine clay. Although unlikely, it is possible that upconing might occur before lateral migration of the interface and could contaminate supply wells. The very low hydraulic conductivity of the marine clay unit suggests, however, that saltwater would move laterally inland above the clay surface more rapidly than upward through the clay unit. 


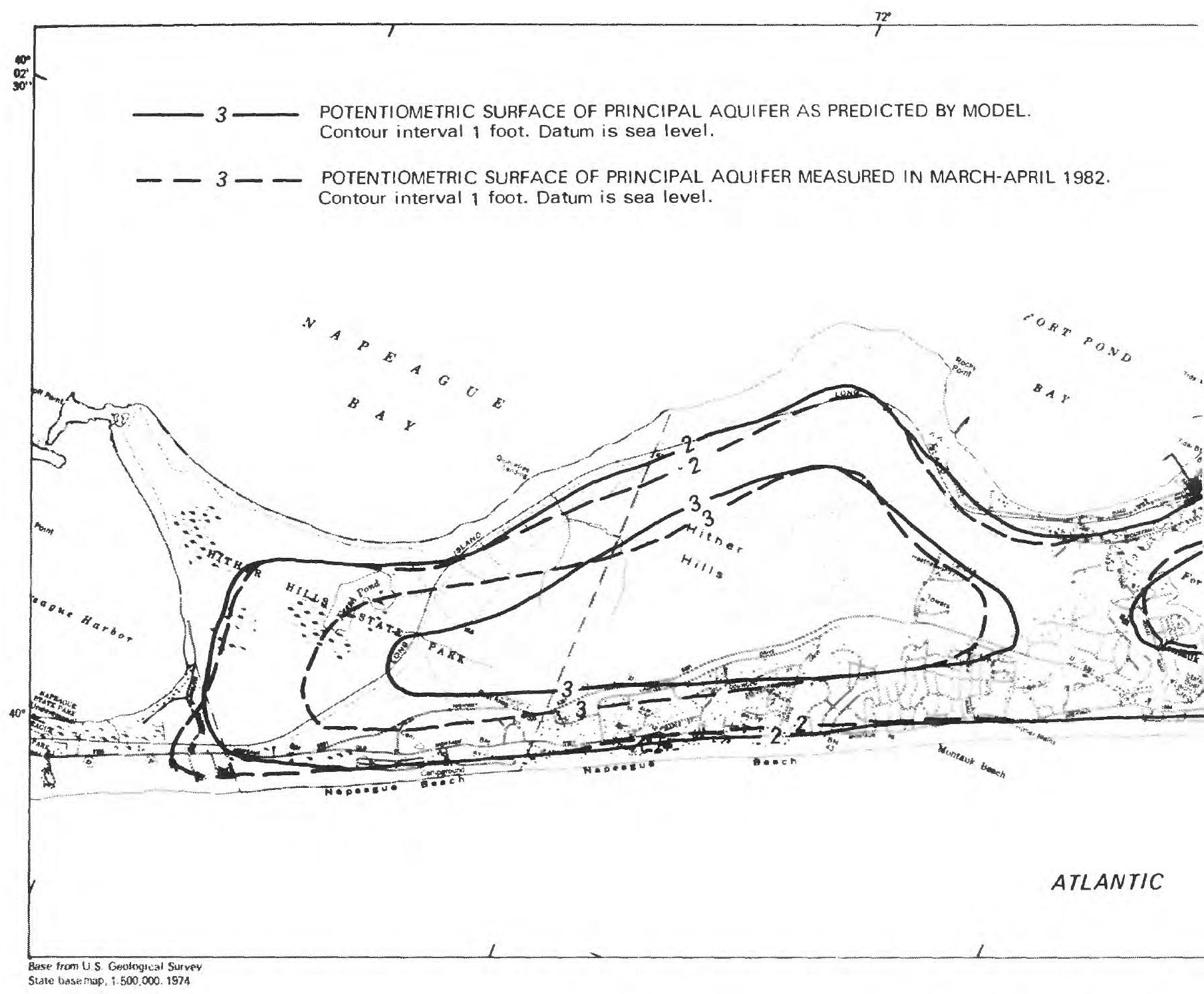

Figure 25.-Comparison of observed and simulatec 


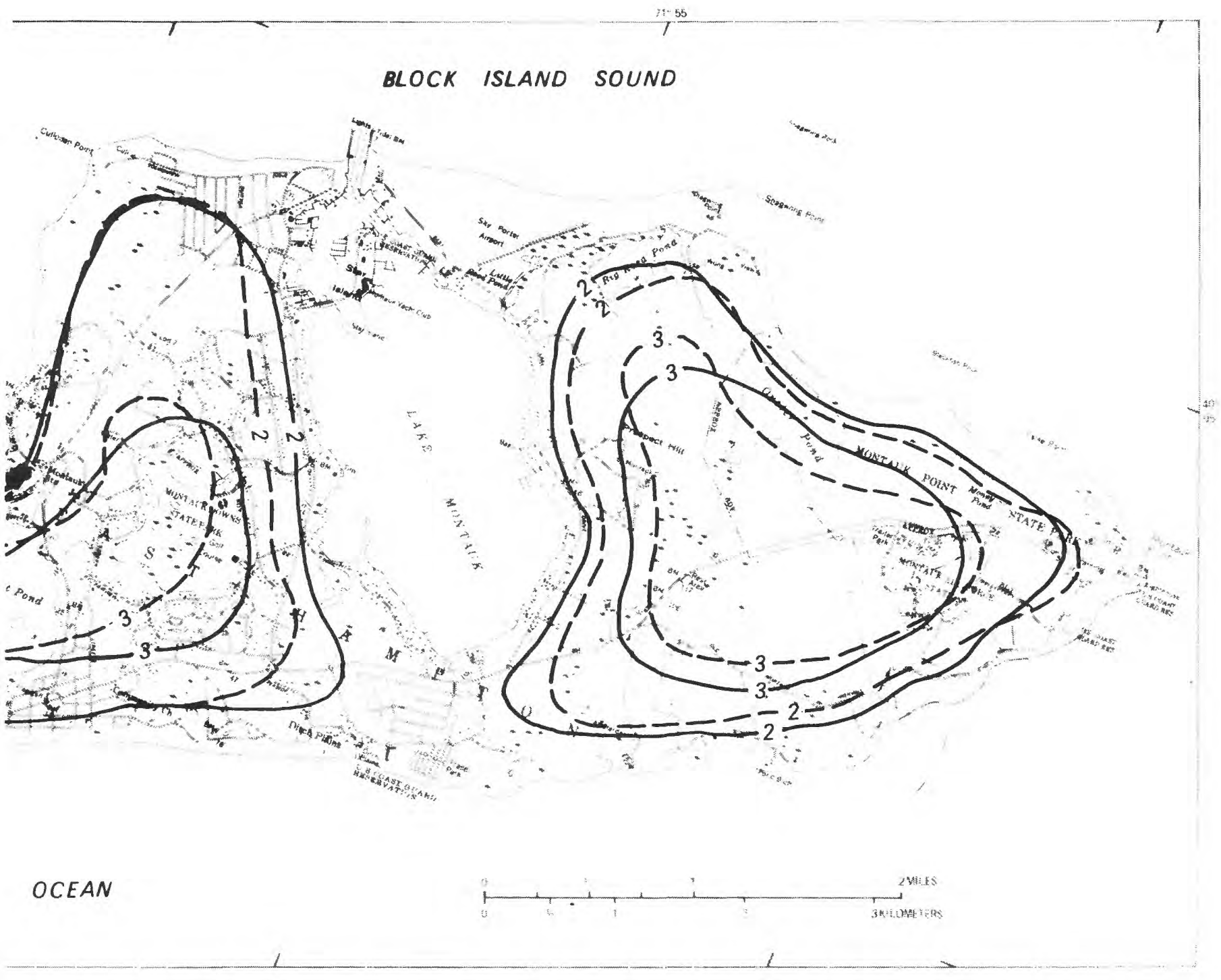

potentiometric surface of the principal aquifer. 


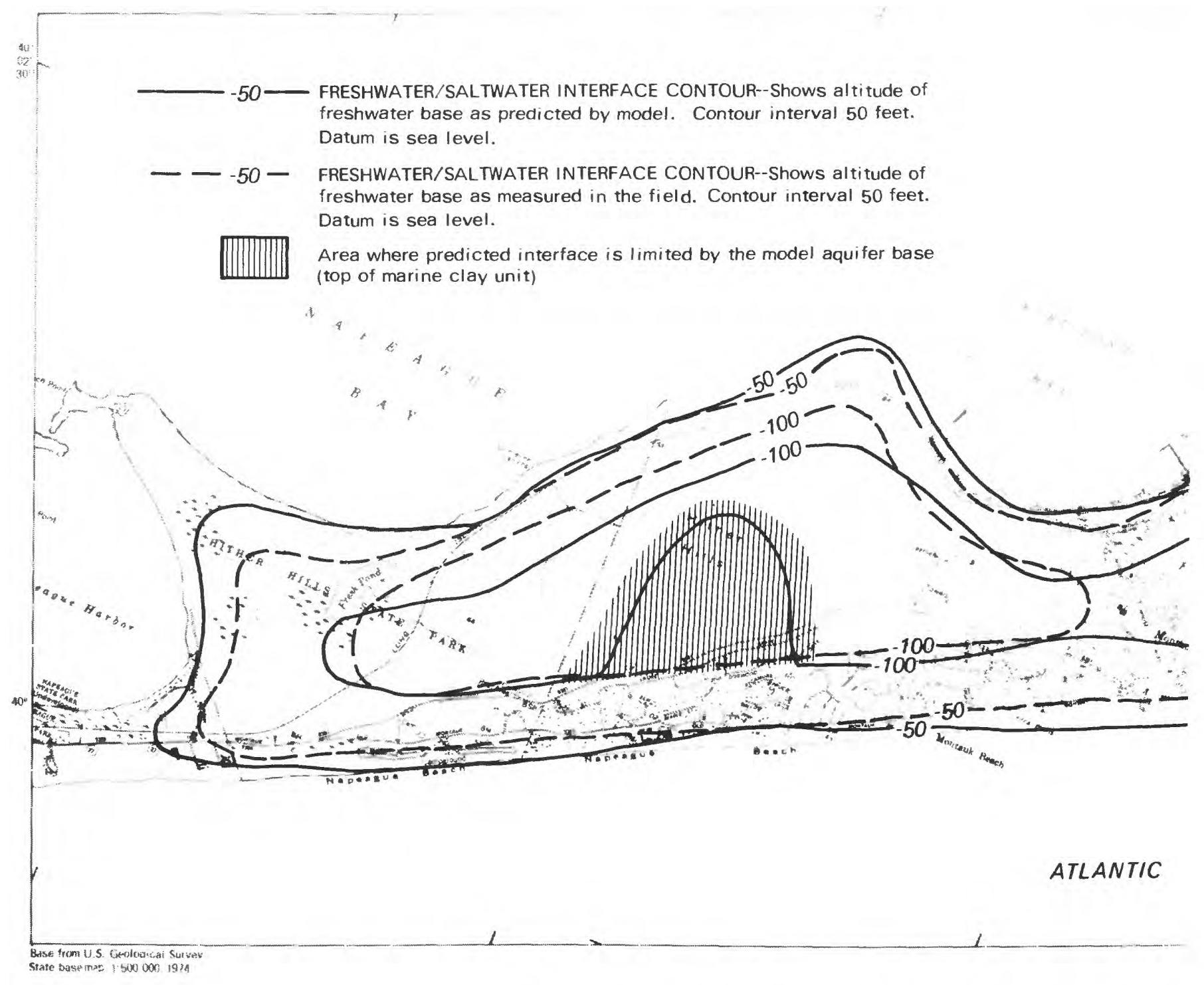

Figure 26.--Comparison of observed and simulated 


\section{Regional Model Acceptance}

Rigorous acceptance testing after the model calibration phase was impossible because the water-level records covered too short a period. Even though a severe drought that occurred on Long Island during 1962-66 provides an ideal hydrologic condition with which to test a model's ability to simulate the ground-water system's response under stress, no wells in the Montauk area were measured during that period. An alternative approach was to simulate predevelopment conditions ( $f i g \cdot 27$ ). Although no predevelopment water-level data on the Montauk area are available, the model-generated water levels can be inspected to evaluate whether they are realistic. Although this approach is less certain than a quantitative comparison with observed data, it confirms that the model is not uniquely tuned to the calibration data.

The predevelopment simulation was developed by removing all man-induced stress from the hydrologic system. A map of the simulated predevelopment

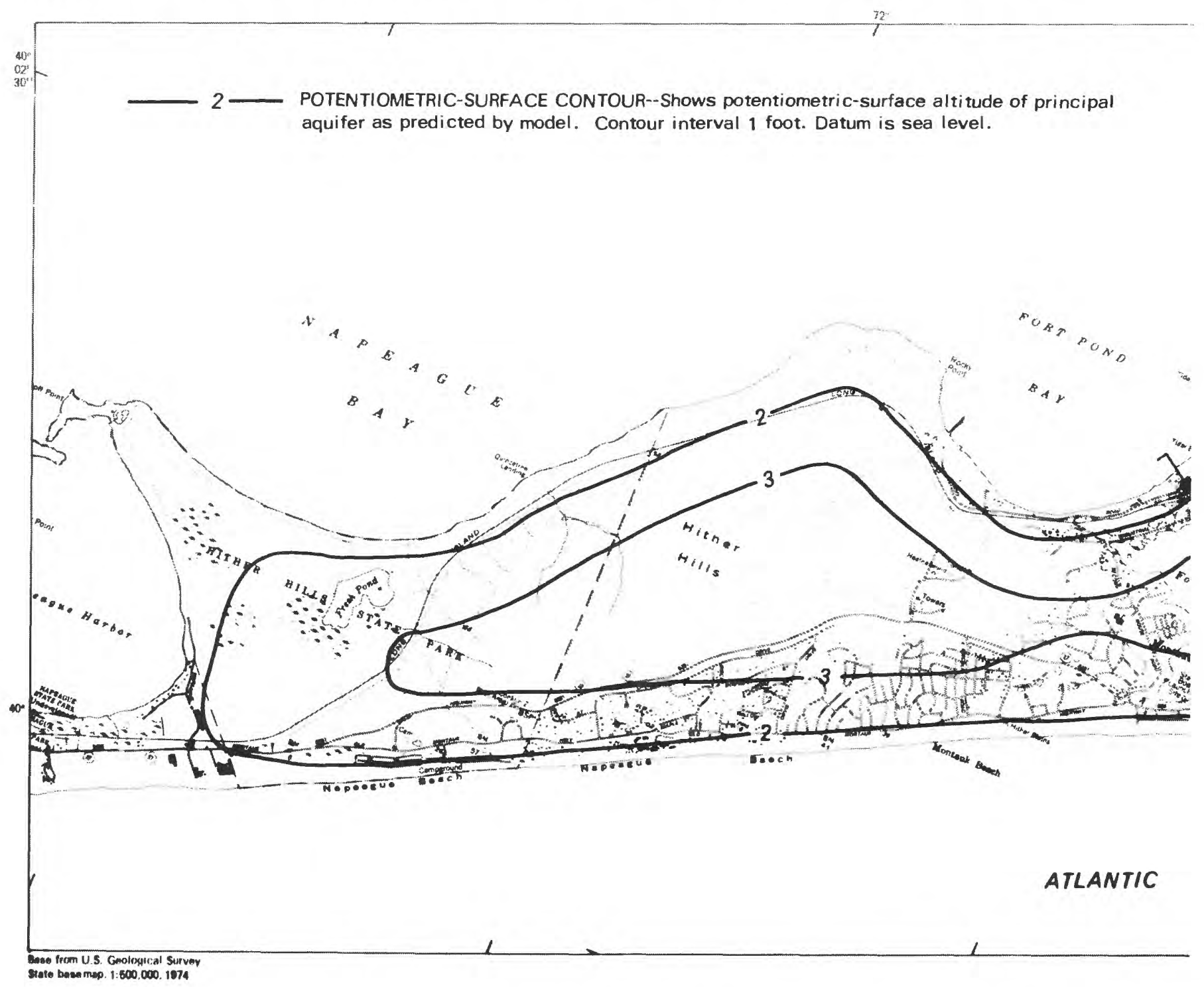

Figure 27.--Simulated potentiometric surface of the 
potentiometric surtace of the principal aquifer is shown in figure 27; the contours differ only slightly from present conditions (fig. 9, p. 18). The major difference is that the predevelopment map shows slightly higher heads in the north-central Montauk area; here the 3-ft contour extends across Fort Pond to Hither Hills. The changes since predevelopment time are in areas where ground-water pumpage is greatest; elsewhere the water levels are unchanged.

As a further model verification, the altitude of the freshwater/saltwater interface was examined ( $f$ ig. 28); its greater depth under predevelopment conditions than at present is consistent with the predevelopment potentiometric surface ( $\mathrm{fig} .27$ ). The area encompassed by the 100-ft contour in the central area of Montauk under predevelopment conditions is slightly larger than that under present conditions ( $f$ ig. 9).

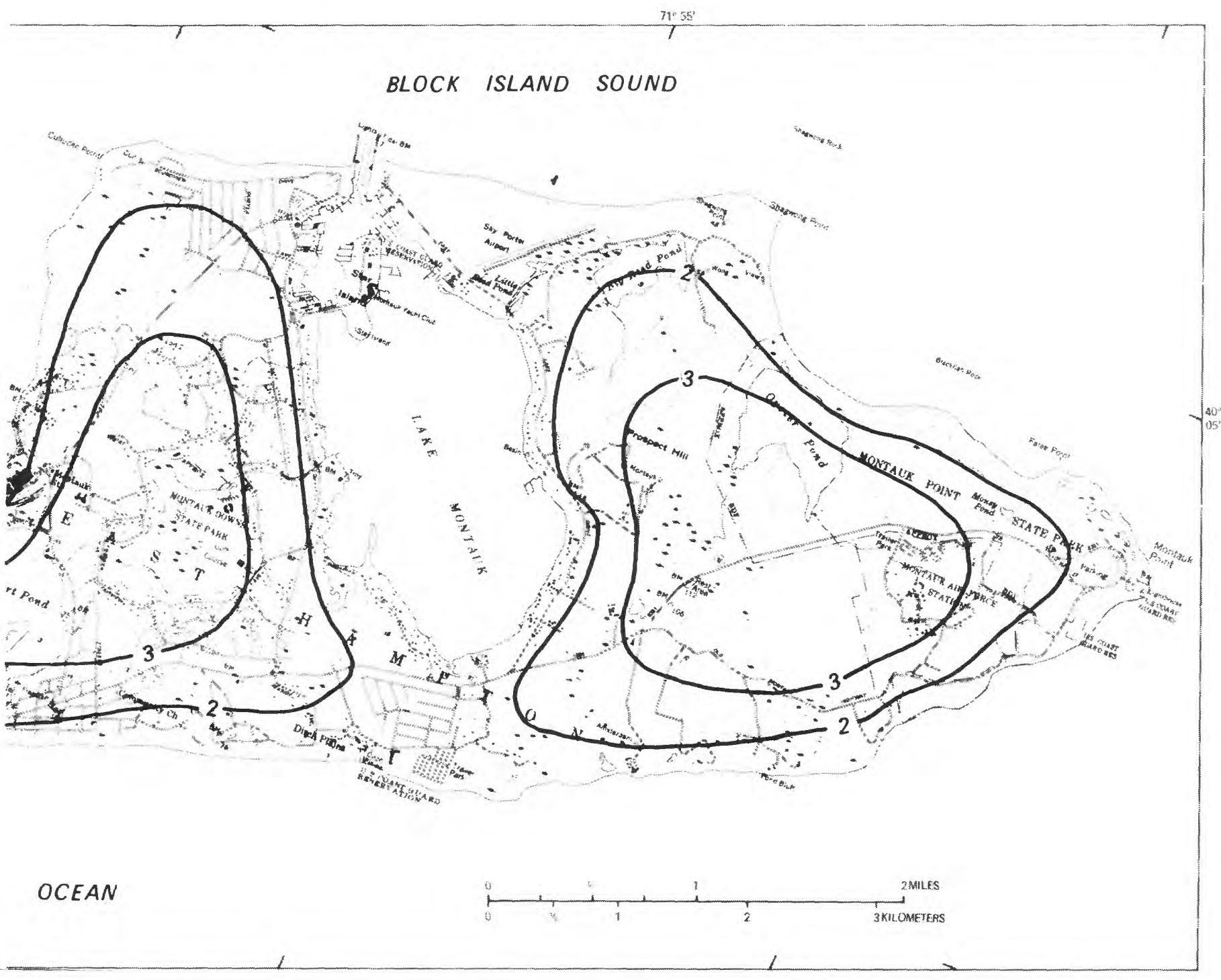

principal aquifer under predevelopment conditions. 


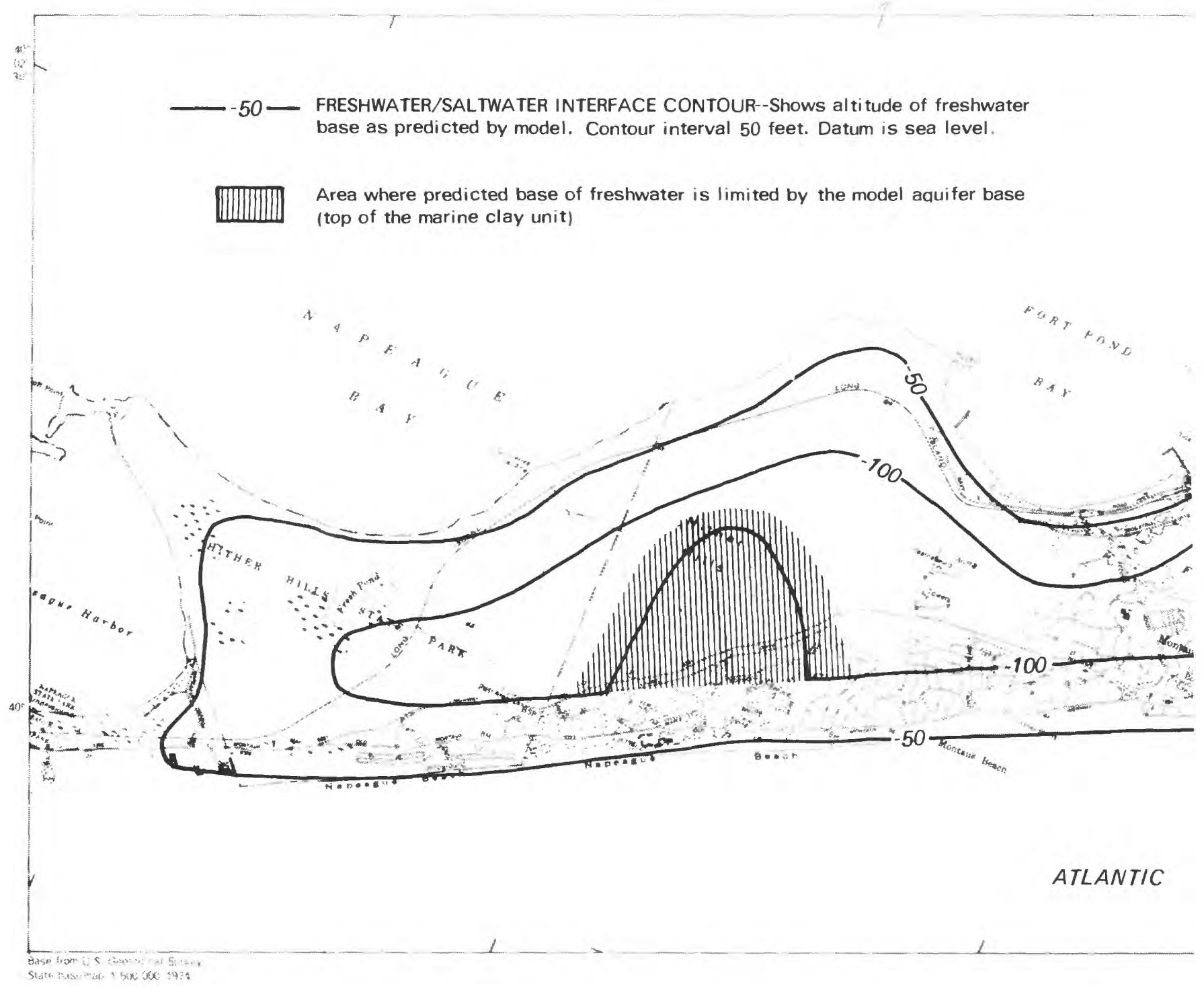

Figure 28.--Simulated altitude of the freshwater/saltwater

\section{Comparison of Predevelopment and Current Ground-Water Conditions}

The simulated predevelopment heads and interface depth can be compared with the simulated present conditions to reveal the effect of current ground-water development upon the aquifer system. On a regional basis, the pumping of approximately $0.5 \mathrm{Mgal} / \mathrm{d}$ by Suffolk County Water Authority has minimal effect on the potentiometric surface and the freshwater/saltwater interface. Comparison of the potentiometric surface under predevelopment 


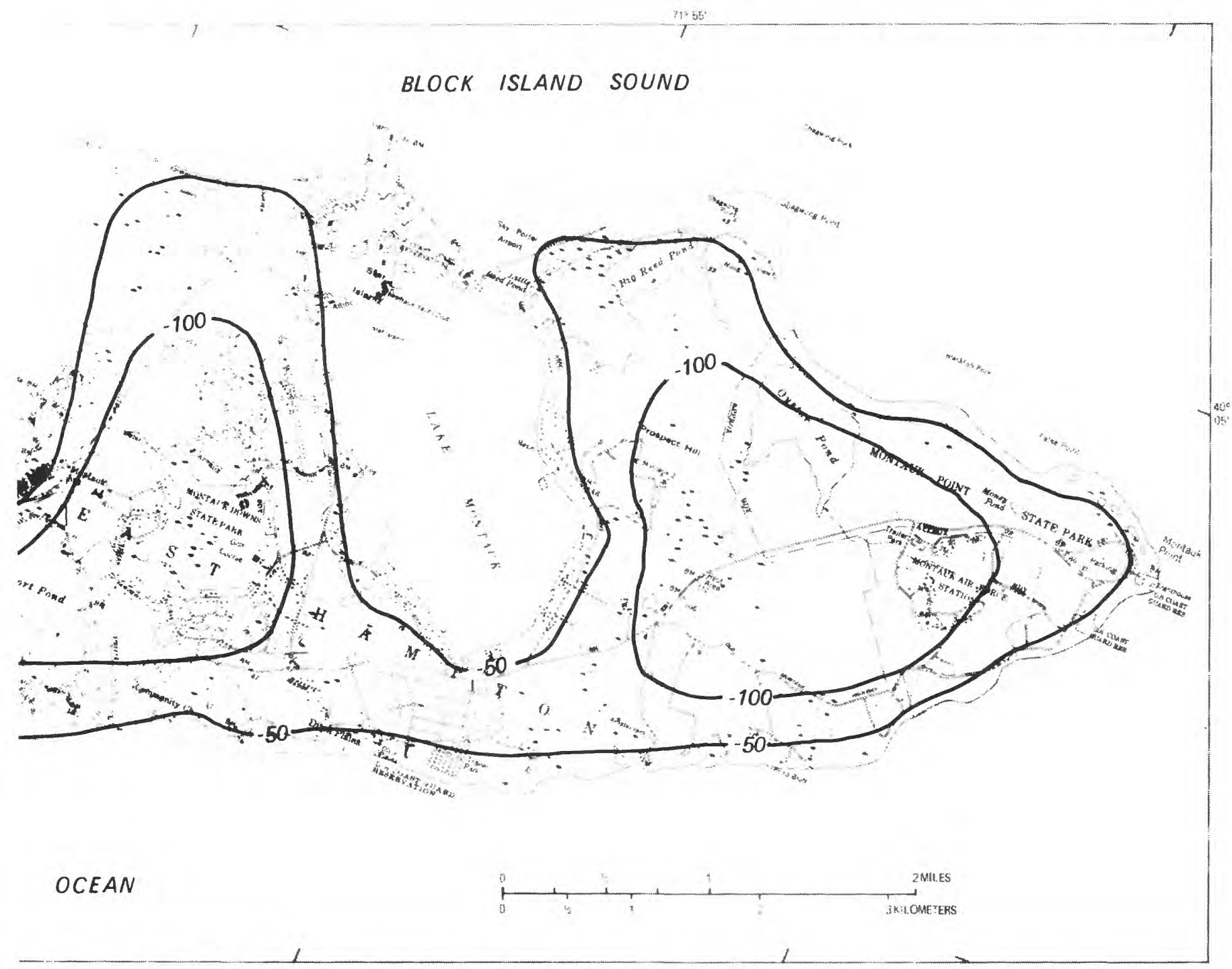

interface under predevelopment conditions.

(fig. 27) with that under present conditions (fig. 25) indicates a maximum decline of about $0.7 \mathrm{ft}$. Similarly, a comparison of the freshwater/saltwater interface under predevelopment (fig. 28) and present conditions (fig. 26) shows a decrease in freshwater thickness of less than $25 \mathrm{ft}$. Although these changes do not seem large, the relatively coarse grid of the model prevents assessment of local effects near individual wells. 


\section{EFFECTS OF FUTURE GROUND-WATER DEVELOPMENT}

\section{Planned Development (1995)}

The Montauk area has a large growth potential tor single-family housing. Development schemes range from building a few scattered single-family houses on vacant land throughout the area to large tracts of cluster housing in undeveloped sections such as Hither Hills. Studies by the Long Island Regional Planning Board (1978) have projected the population to be 4,730 by 1995. The increased population will place additional stress upon the ground-water system, which is already experiencing large drawdowns and local. saltwater intrusion from the present level of development.

The projected 1995 population amounts to an increase of about 2,090 residents and 630 households over the 1980 levels. Water use is assumed to average $350 \mathrm{gal} / \mathrm{d}$ per dwelling unit, 75 percent of which is returned to the aquifer through cesspools. This increase will require an additional average capacity of about $200,000 \mathrm{gal} / \mathrm{d}$ above the present average daily pumpage rate by the Suffolk County Water Authority. For modeling purposes, this additional pumpage was simulated at six additional wells in an area of Hither Hills that is soon to be develcped, as shown in figure 29.

The proposed development will be low-density housing with a total of about 450 units. Of the total 630 additional units proposed for the Montauk peninsula, the remaining 180 units will be built elsewhere, mostly within the areas now served by Suffolk County Water Authority.

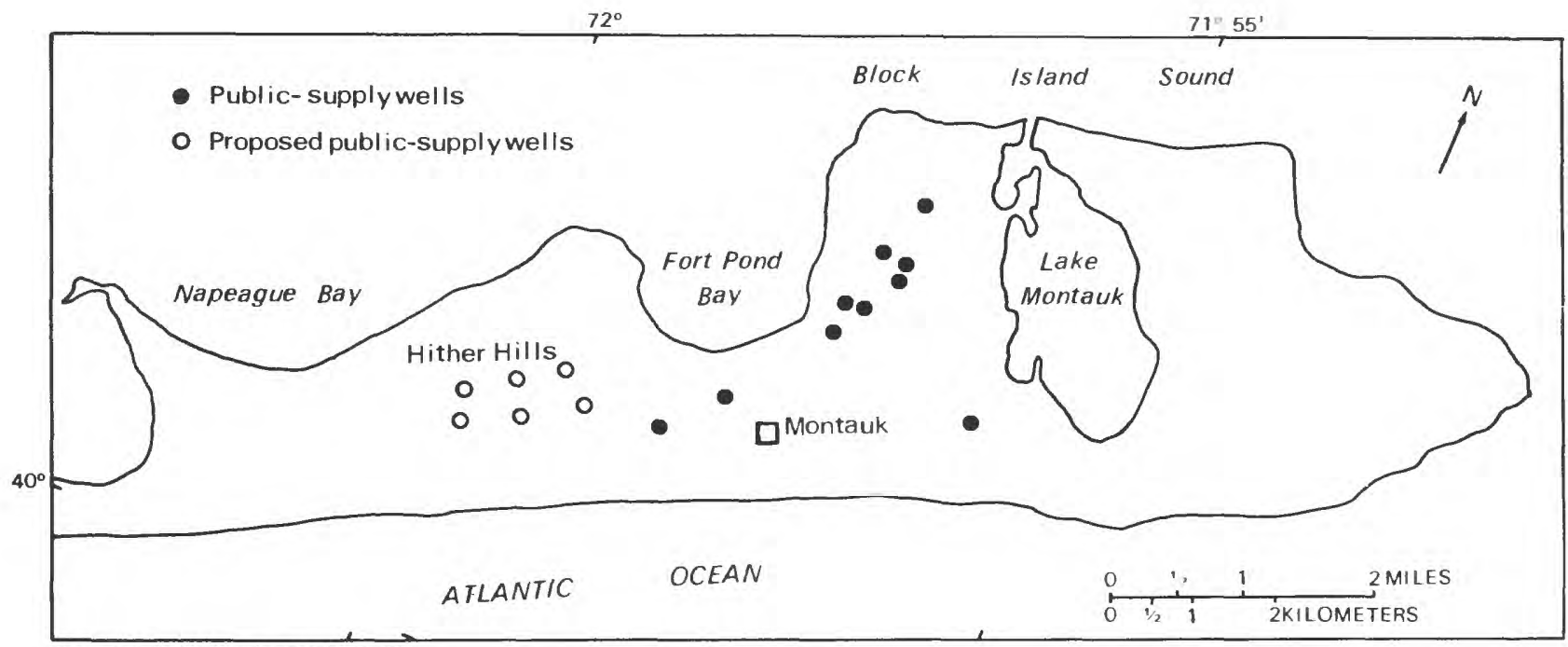

Base from U.S. Geological Survey

State base map, $1500,000,1974$

Eigure 29.--Proposed location of public-supply wells in the Montauk area, 1995. 
The effects of future development of the ground-water resources in the Montauk area were investigated by stressing the model at a level equivalent to the projected average daily pumpage in 1995 under steady-state average recharge and discharge conditions. The pumpage applied to the model was as follows: (1) the 1982 pumping rate was maintained at the nine Suffolk County Water Authority well fields, (2) an additional 200,000 gal/d was pumped from six proposed public-supply wells in Hither Hills (fig. 29), and (3) pumpage by five other major users in the area (table 4) was increased 20 percent over the 1977-81 average.

The nonconsumptive part of the water pumped for public supply was redistributed over the present area of Suffolk Couty Water Authority's Montauk distribution system and over the area of Hither Hills where future development is planned. The redistribution was done in two ways. The nonconsumptive part ( 75 percent) of the estimated $157,000 \mathrm{gal} / \mathrm{d}$ needed to supply the Hither Hills area was returned as recharge in that area. Some additional development will also occur outside the Suffolk County Water Authority's present distribution network; therefore, recharge from nonconsumptive use to the remaining distribution area was reduced by an additional 10 percent. Thus, approximately $118,000 \mathrm{gal} / \mathrm{d}$ was returned as recharge in Hither Hills and 693,959 gal/d over the remaining part of the Suffolk County Water Authority distribution system (fig. 13).

The stress as outlined above was used to predict the steady-state (equilibrium) hydrologic conditions resulting from the projected level of development by 1995. The simulation assumes average recharge and evapotranspiration and no sanitary sewers.

\section{Model Results}

The predicted freshwater head that results from the projected 1995 stress under equilibrium conditions is shown in figure 30 . The contours show little change from present conditions (fig. 25) in areas east of Fort Pond, but in Hither Hills, where the six additional supply wells were simulated, a small decline is evident. Freshwater head declined a maximum of $0.2 \mathrm{ft}$ from present conditions at the nodes in Hither Hills where the proposed supply wells were located.

Minor changes are also predicted in the altitude of the base of freshwater under projected 1995 stresses (fig. 31); the maximum rise would be $7 \mathrm{ft}$ above the present level (fig. 26). The greatest change is near Fort Pond, where the interface rises to just above $-100 \mathrm{ft}$, so that the $-100 \mathrm{ft}$ contour will form two separate areas after development.

The most notable feature of this simulation is the lack of change in the altitude of the interface in the Hither Hills area. Its steady-state altitude in 1995 does not differ enough from the present level to induce significant lateral movement of the saltwater toe, which indicates that future wells in the Hither Hills area may be less prone to saltwater contamination than those elsewhere. The reason for this is that the aquifer beneath the wells contains freshwater down to the marine clay, and the interface is below the clay. 
Two important points concerning the risk of saltwater encroachment and future development in this area cannot be addressed by the mode1. First, the rate of saltwater movement upward through the marine clay unit in response to ground-water pumping cannot be assessed because the model simulates the martne clay unit as an impermeable boundary. However, saltwater is unlikely to move through the marine clay unit before the saltwater toe moves inland above the clay unit. Second, the average pumping rate for each well used in the model may be significantly lower than the peak pumping rate, and seasonal pumping at higher rates would certainly induce saltwater encroachment sooner than the steady-state model results indicate.

\section{Sustained Peak Pumpage}

Pumping rates can vary widely both seasonally and daily. Peak pumpage rates can he many times the average daily pumpage rate; for example, pumpage
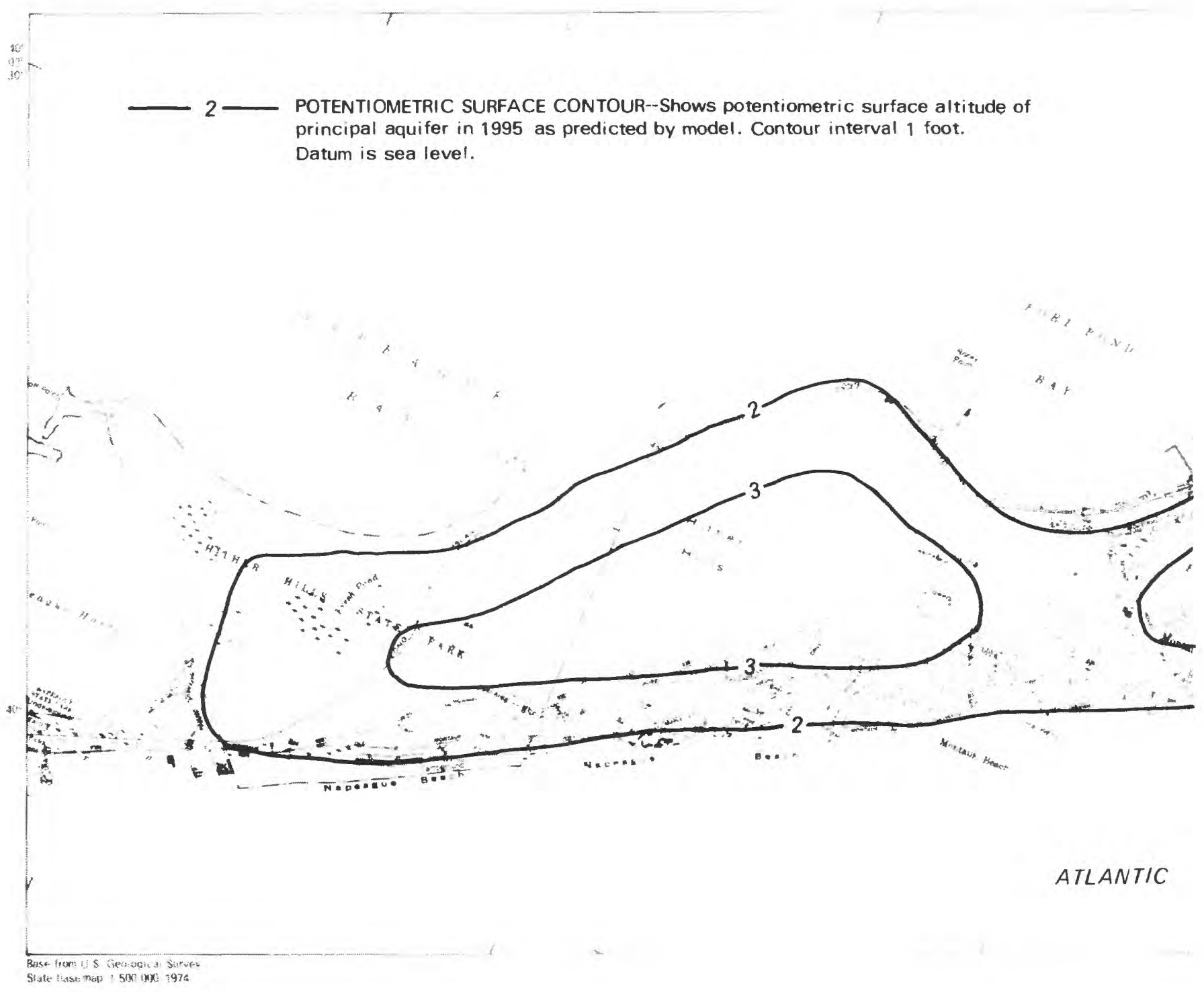

Figure 30.--Predicted 1995 potentiometric 
on the peak demand day in 1982 was slightly more than double the average daily pumpage (written commun., Suffolk County Water Authority, 1983). The response of the ground-water system to seasonal stresses such as peak pumpage can be properly simulated only with a transient-state model, which was beyond the scope of this study.

\section{Modeled Stress}

To approximate the "worst case" effect of stress, the equilihrium response of the system to a stress twice the projected average 1995 pumping rate was simulated. Although this is not directly analogous to peak demand, it represents a much more intense stress than if peak demand were to occur for only a day or even an entire season. Pumping wells were placed at the same locations as in the projected 1995 average daily-pumpage simulation, and the pumpage at all wells was doubled, as was the distribution of recharge from nonconsumptive use.

\section{BLOCK ISLAND SOUND}

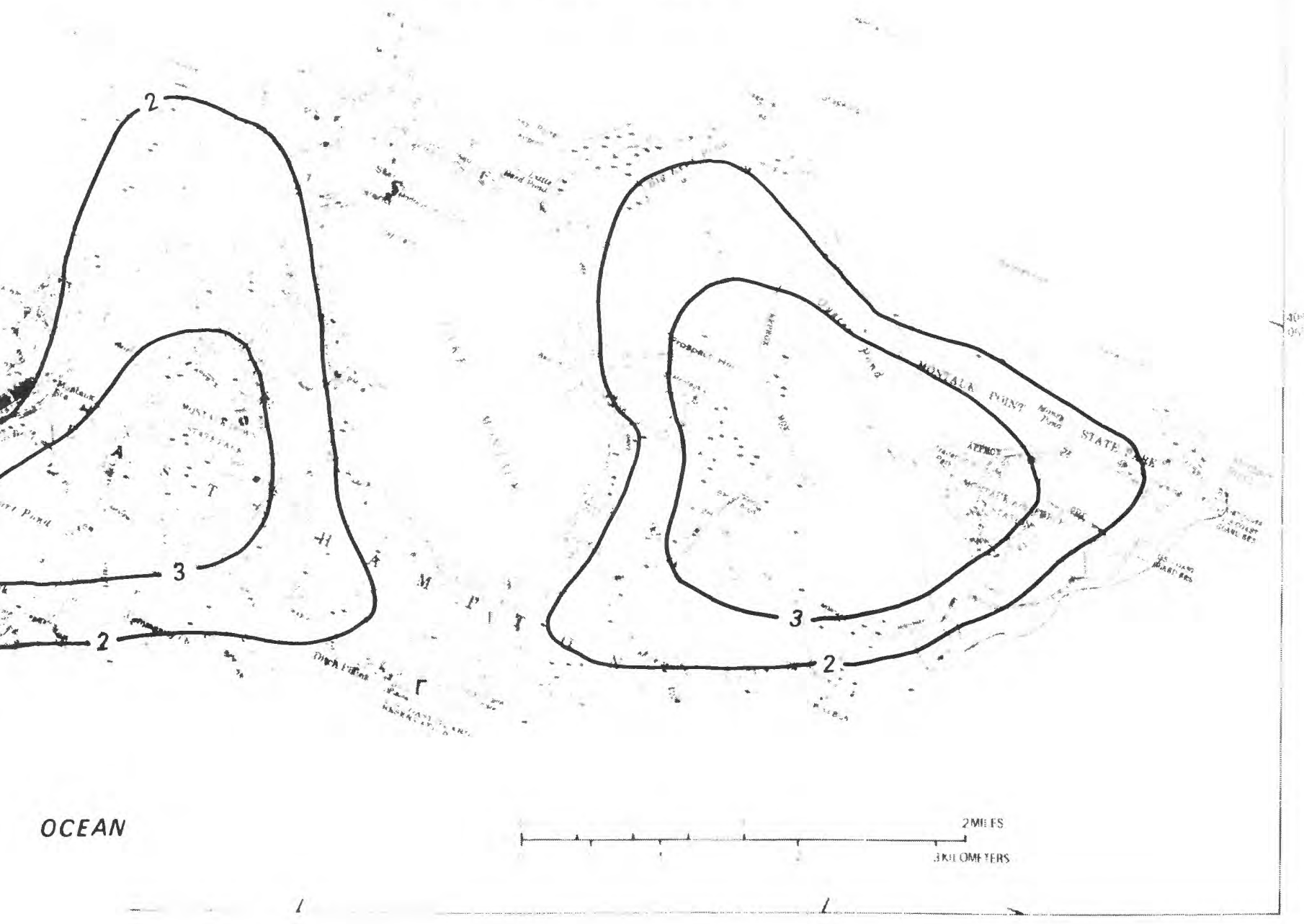

surface of the principal aquifer. 


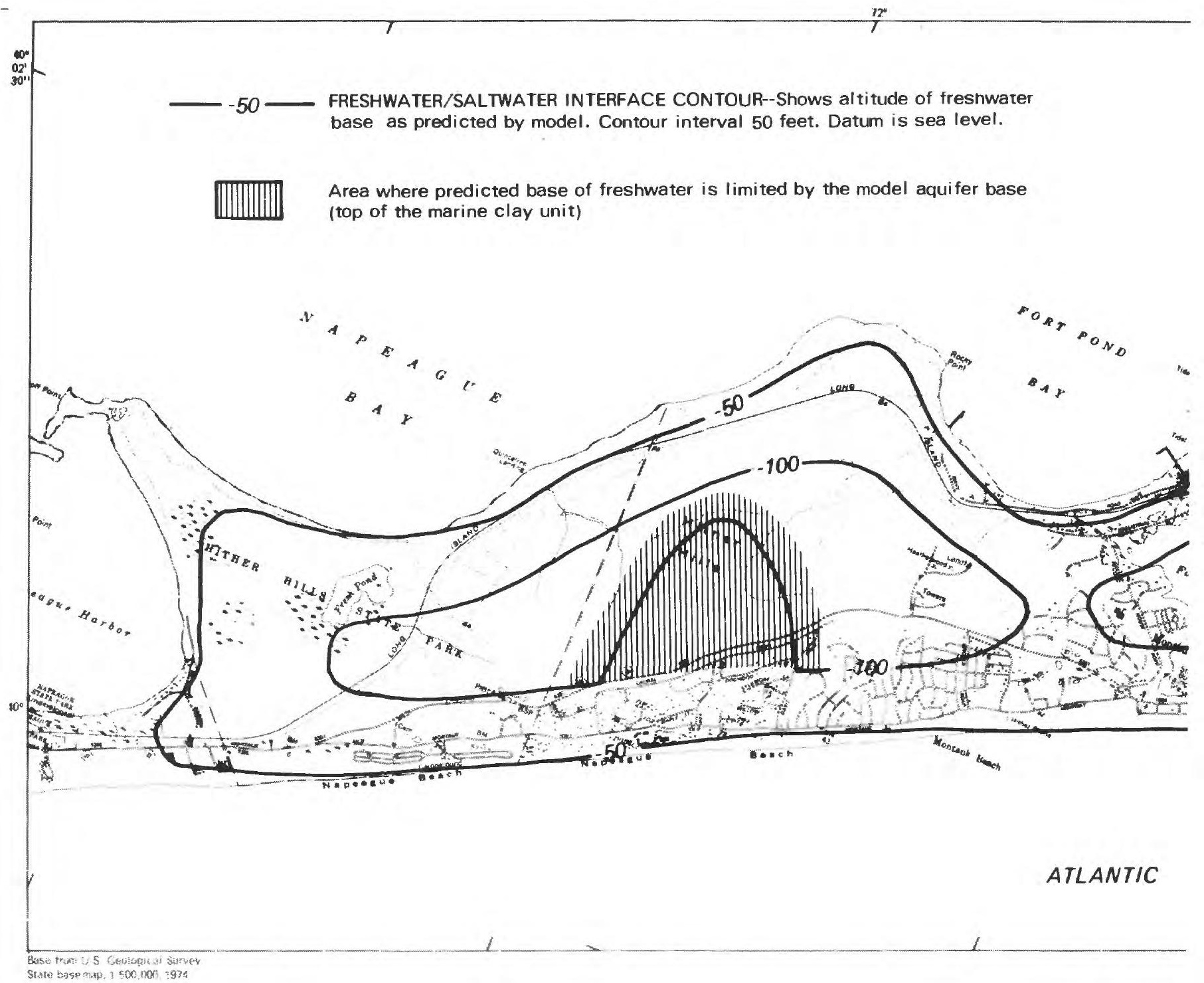

Figure 31.--Predicted 1995 altitude of the 


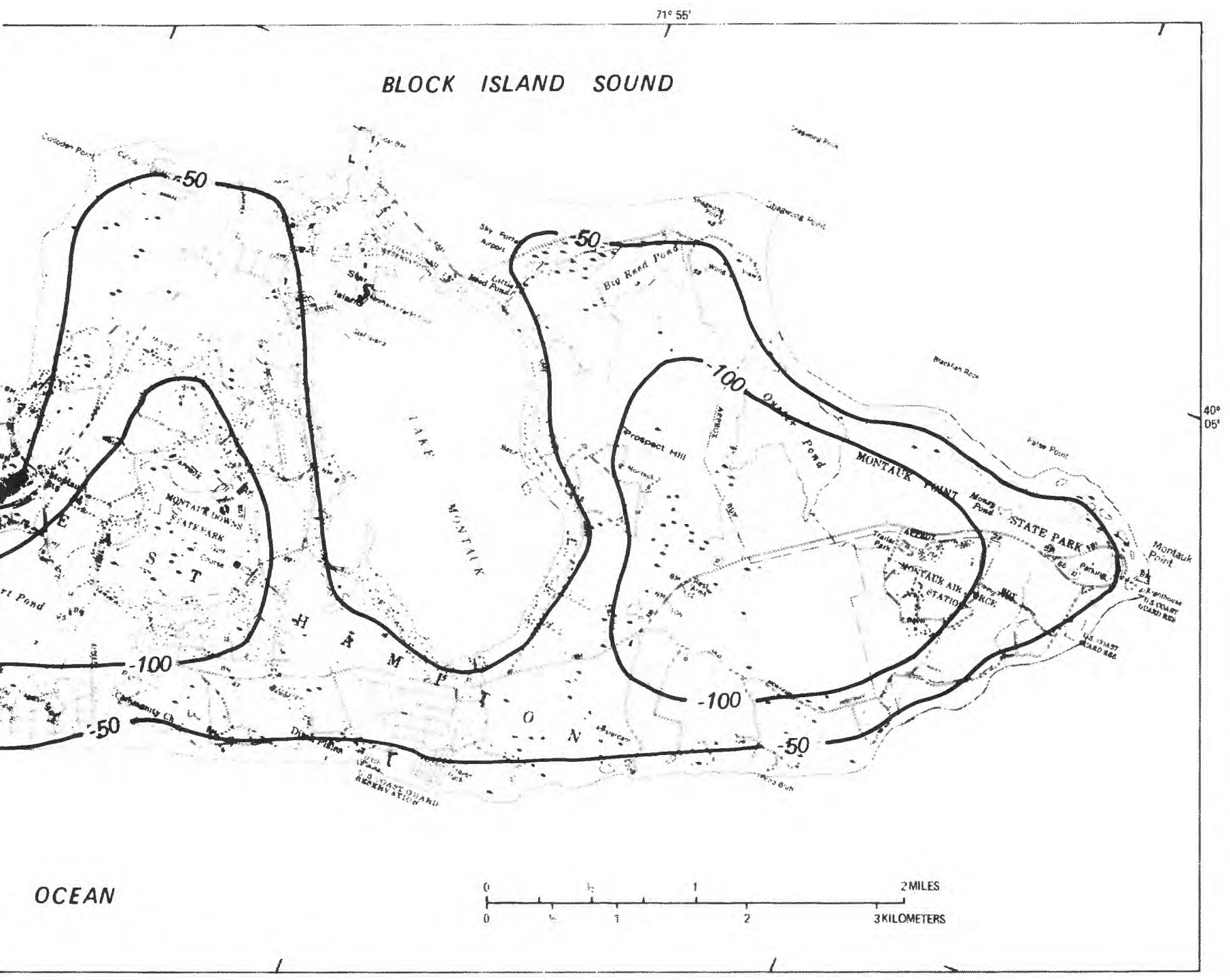

freshwater/saltwater interface. 


\section{Model Results}

The predicted freshwater head, under equilibrium conditions, resulting from the doubling of the projected 1995 stress is shown in figure 32 . The resulting heads indicate some significant declines in the potentiometric surface with a few minor cones of depression in Hither Hills and the central Montauk area. The maximum decline in freshwater head from the present average conditions (calibrated model) is $1.14 \mathrm{ft}$ in the central Montauk area and 0.47 ft in the Hither Hills area.

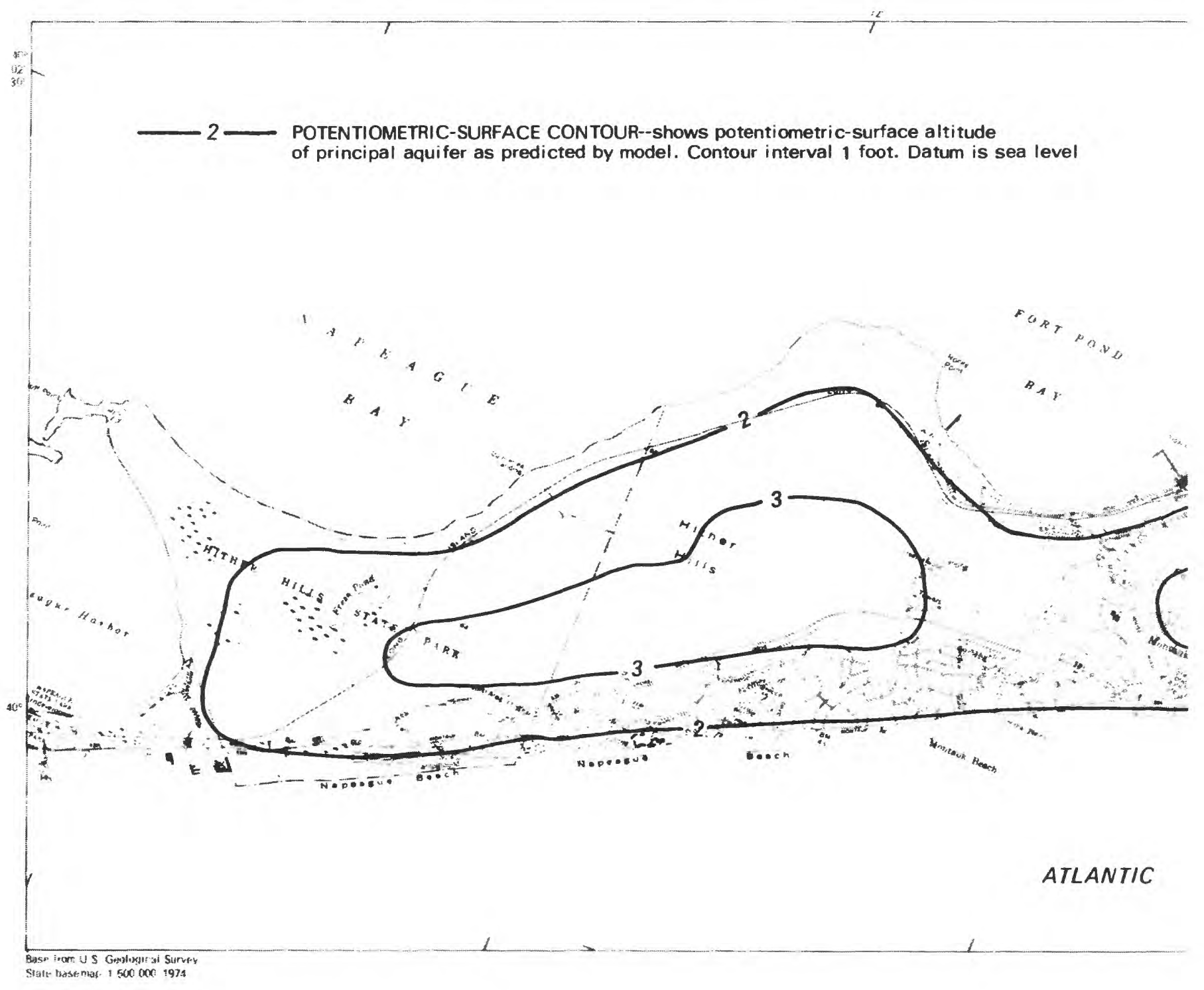

Figure 32.--Predicted potentiometric surface of the 


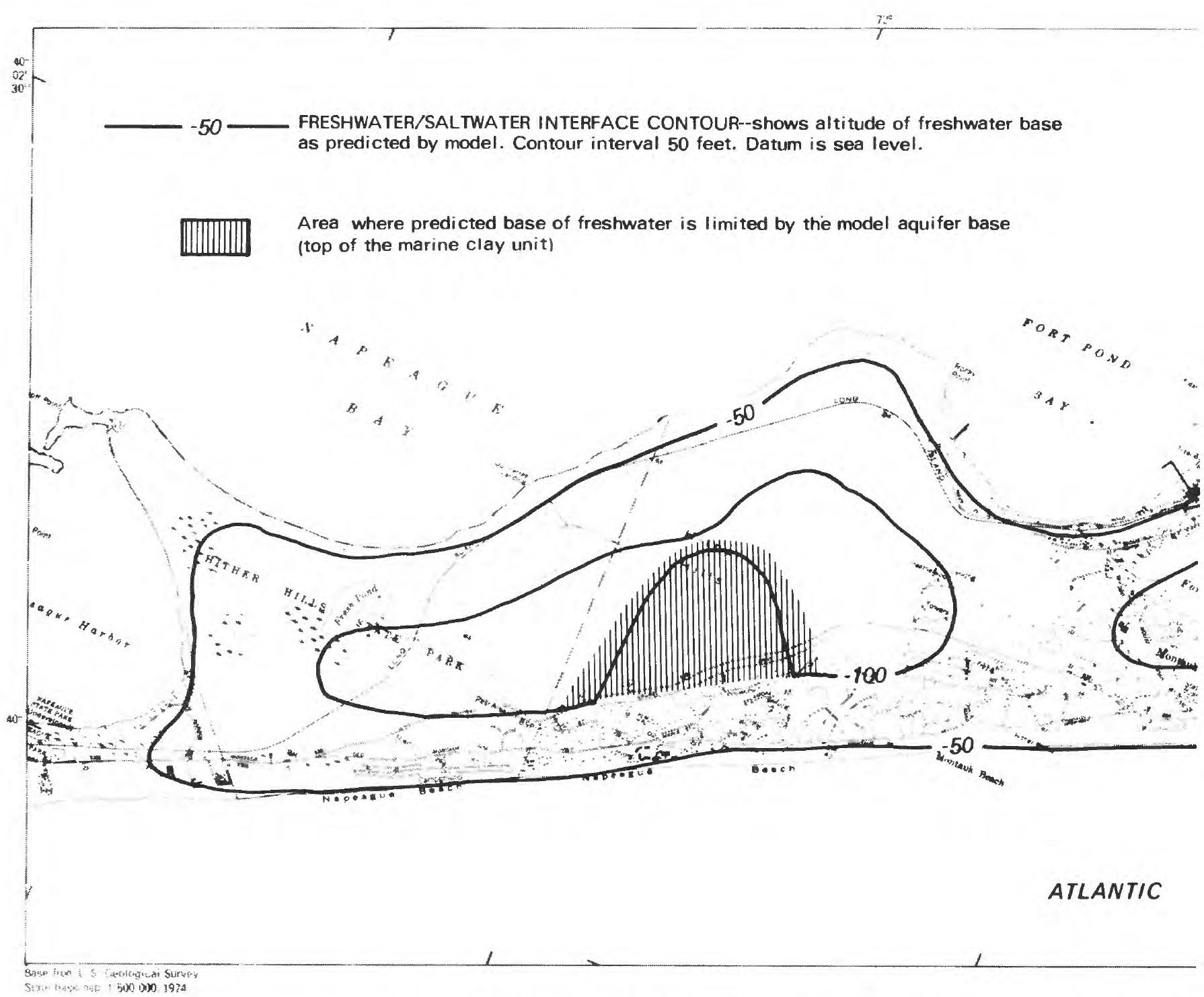

Figure 33.--Predicted altitude of the freshwater/saltwater

\section{Conclusions From Model Studies}

Comparison of water levels and saltwater-interface altitude under predevelopment conditions with those under present average conditions shows only minor changes, which indicates that current ground-water withdrawals have not affected the system adversely at a regional scale.

The model response to ground-water withdrawals for the projected 1995 population also indicates a sufficient freshwater supply, and, on a regional scale, the projected average daily pumpage needed to supply the 1995 population will not significantly change the ground-water system from current conditions. These results are based on the assumption that ground-water withdrawals for the additional demand will be supplied from the Hither Hills area. 


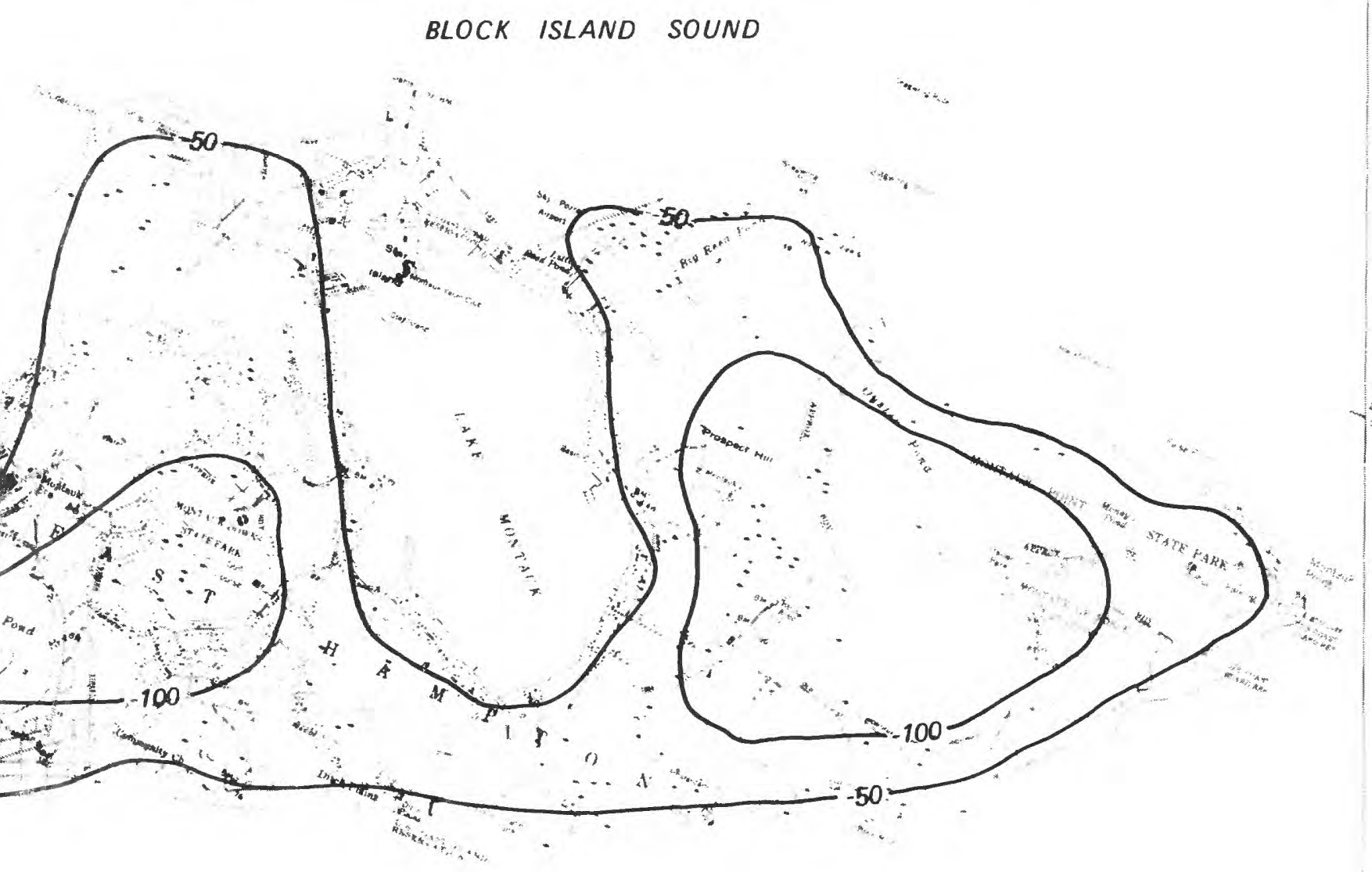

OCEAN

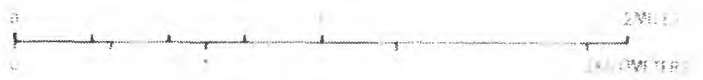

nterface at double the projected 1995 stress.

Doubling the 1995 ground-water pumpage provides a general indication of the system's response to peaks in pumpage, although seasonal and daily peaks cannot be simulated on a steady-state model. Doubling the 1995 pumpage as a steady-state condition constitutes a greater stress upon the system than daily or seasonal withdrawals at the same rate. Declines in freshwater head in response to transient stress would be relatively rapid, but regional movement of the saltwater interface would be relatively slow. Therefore, cyclic peak stresses may have only minor effects upon the interface on a regional basis. Also, local upconing may occur in a small area around a well as a result of localized head declines and high ground-water velocities, but this cannot be addressed with the current model. In areas where the model indicates that water-supply problems may occur as a result of saltwater movement, the natural system's response to transient peaks may be smaller than indicated, and 
periodic high withdrawal rates might safely be used. Although the doubled 1995 steady-state stress indicates that saltwater intrusion may occur in the central Montauk area, this could be minimized or avoided if peak pumpage were distributed more uniformly over the Montauk area than was done in the model.

\section{SITE-SPECIFIC CONSIDERATIONS}

The areal flow model used in this study indicates a substantial reserve of recoverable freshwater on the Montauk peninsula and also indicates that present pumping rates will not cause increased saltwater intrusion. However, water samples from public-supply wells indicate slightly elevated chloride concentrations resulting from saltwater intrusion. The change in chloride concentration through time and in relation to ground-water pumpage is plotted in figures 18 and 19 ( $\mathrm{p} .38,39$ ). The discrepancy between the model simulations and the actual conditions can be attributed to three factors: (1) the regional scale of the model, which cannot provide accurate response over small local areas; (2) the two-dimensional representation of three-dimensional flow; and (3) simplified representation of the interface. The effects of these factors are discussed in detail below.

\section{Limitations in Modeling Local Stresses}

The model was designed to simulate only the regional response to stress; therefore, conditions resulting from localized stresses such as pumping from a public-supply well cannot be accurately predicted. The main reason is the vast difference in scale, where the model predicts freshwater heads and interface altitudes as an average over each grid block $(1,000 \mathrm{ft} \times 1,000 \mathrm{ft})$. Thus, an observed drawdown of $2 \mathrm{ft}$ near a pumping well could become an order of magnitude smaller when averaged over the entire model block. The predicted average altitude of the interface could be similarly misleading.

One solution to this discrepancy would be to decrease the block size of the model to accommodate localized effects, but this is impractical for two reasons. First, the ground-water potential around high-capacity wells varies greatly both horizontally and vertically and induces three-dimensional flow locally, while two-dimensional flow predominates elsewhere. The computer code used to solve the ground-water flow equations is based on the assumption that equipotential lines are vertical within the aquifer--in other words, that the system has no vertical gradients. On a regional scale, vertical gradients within the aquifer are minimal and cause only minor errors, but near a pumping we11, where vertical gradients become many times greater than those under natural conditions, large errors in model predictions of both freshwater head and saltwater-interface altitudes may occur. Second, a grid mesh fine enough to accurately represent both regional and local response to pumping stresses would require large amounts of computer storage. Practical limits of computation time for model runs would be exceeded, and the simulations would become prohibitively costly. 


\section{Limitations in Modeling the Freshwater/Saltwater Interface}

An additional factor that restricts use of the model to predict drawdowns near a pumping well is the simplified representation of the freshwater/ saltwater interface. The equations solved in the model computer code are based upon the assumption that the two fluids (freshwater and saltwater) are immiscible and separated by a sharp interface. In reality, however, the two fluids are miscible, and the interface is a zone of dispersion. In largescale areal simulations, this discrepancy has only a minor effect upon model results, but on a smaller scale, the error can be larger. In addition, a high-capacity pumping well operated cyclically causes high ground-water velocities and possibly saltwater upconing, both of which increase the hydrodynamic dispersion and thus broaden the transition zone between saltwater and freshwater.

\section{Saltwater Upconing}

Saltwater upconing in the Montauk area is imminent, as evidenced by elevated chloride concentrations in water from public-supply wells. Investigation of this phenomenon requires detailed study at individual sites. Most analytical methods used to predict saltwater upconing beneath a pumping well are inaccurate because of the need for simplifying assumptions in the analysis. Numerical methods have been developed and used by Hsieh (1977) to investigate upconing elsewhere on the south fork. Although that model provided information about the depth of the interface, the amount of computer time necessary to obtain solutions proved too costly for application in this study.

Even though development of a site-specific numerical model to simulate saltwater upconing to a pumping well was beyond the scope of this study, several aspects of the problem are addressed below.

Saltwater upconing is highly sensitive to the pumping rate. Under certain conditions, a stable saltwater cone can form beneath a well pumping at a steady rate, and when the pumping rate is increased, a new stable saltwater cone will form after a transition period. If the pumping rate continues to increase, however, a critical state will eventually be reached at which the depth of the interface becomes unstable, and any further increase in pumping rate will cause the cone to intersect the well screen, thereby introducing saline water. If the well is pumped at an excessive rate intermittently, the cone will move upward toward the well until pumping ceases, then will drop back toward the prepumping level. Repeated movement of the cone in this manner will gradually broaden the zone of diffusion by hydrodynamic dispersion, molecular dispersion, and mixing, and eventually salty water will enter the pumping we11--a situation now occurring on the Montauk area.

To avoid the introduction of brine into a well, a conservative approach to well construction and operation should be taken, whereby pumping rates and schedules allow a safe and stable cone to develop that the maximum stress will not alter. 


\section{Method of Investigation}

Stable coning of brine beneath freshwater wells was studied by Bennett and others (1968) through a combination of a graphical procedure developed by Muskat (1937) to locate the interface and an electric-analog flow model to predict the head distribution about the we1l. The flow model was constructed to simulate equilibrium axisymmetric flow to a well, as described by Stallman (1963).

Through the technique of successive approximation, the highest stable brine cone was found for each of 18 different experimental pumping schemes. Six different screen penetrations were simulated under three values of the flow-net constant

$$
\left(\begin{array}{c}
\mathrm{h}_{\mathrm{o}} \\
-\mathrm{r}_{\mathrm{e}}
\end{array}\right)^{2} \frac{\mathrm{k}_{1}}{\mathrm{k}_{\mathrm{z}}}
$$

where: $h_{0}$ is initial thickness of freshwater,

$r_{e}$ is radius of influence of well,

$\mathrm{K}_{1}$ is horizontal hydraulic conductivity, and

$\mathrm{K}_{\mathrm{z}}$ is vertical hydraulic conductivity.

The problem is investigated under certain assumptions and boundary conditions, as detailed by Bennett and others (1968). The main assumptions are that: steady-state flow prevails; (2) drawdown, $h_{o}-h_{w}$, is a small fraction of the freshwater thickness; ( 3 ) steady-state flow is sustained by uniform areal recharge over the area of influence of the well; (4) the constant-potential boundary at the radius of influence of the well, $r_{e}$, is equal to the head throughout the freshwater aquifer before pumping; and (5) the well screen is considered a cylinder coaxial with the $z$ axis, and its geometry is described by the fractional elevations of its top, $z_{t} / h_{o}$, bottom, $z_{b} / h_{o}$, and fractional radius, $r_{w} / r_{e}$,

where: $Z_{t}$ is distance from initial interface location to screen top;

$\mathrm{Z}_{\mathrm{b}}$ is distance from initial interface location to screen bottom, and $r_{\mathrm{w}}$ is radius of well.

In the experiments by Bennett and others (1968), flow-net constants $\left[\left(h_{o} / r_{\epsilon}\right)^{2} K_{1} / k_{z}\right]$ of $1.71,0.423$ and 0.0256 were investigated. The ratio of the screen radius to the radius of influence, $r_{w} / r_{e}$, was $1: 2,896$, and the top of the screen was set at $z_{t} / h_{o}=0.95$. The screen bottom was set at $z_{b} / h_{o}=$ $0.35,0.45,0.55,0.65,0.75$, and 0.85 in the six experiments at each flow-net constant. From these experiments, 18 dimensionless flow nets were drawn that detail the location of the brine cone, fractional potential lines, and flow tubes, and several terms were introduced. Maximum permissible drawdown is defined as the maximum drawdown at which the well can be operated with no inflow of saltwater for a given density contrast and original freshwater thickness. Similarly, the specific-capacity function indicates the well's specific capacity with no inflow of saltwater for a given horizontal hydraulic conductivity and original freshwater thickness. The product of the maximum permissible drawdown function and the dimensionless specific-capacity function indicates the maximum permissible discharge at which the well can operate without drawing saltwater into the well. This is based on a given density 
contrast between fresh and saltwater, original freshwater thickness, and horizontal hydraulic conductivity. In addition, dimensionless plots of specific capacity, maximum permissible drawdown, and maximum permissible discharge versus altitude of screen bottom were provided in Bennett and others (1968).

The experimental results show a certain highest point of safe saltwater upconing for all wells pumping freshwater above static saltwater. This highest stable position is a function of the flow-net constant and the boundary conditions, particularly the altitude of the screen top and bottom and the screen radius. The highest stable cone position is the same regardless of the density contrast, but the drawdown and freshwater discharge associated with the highest stable cone position increase as the density contrast increases.

The dimensionless analysis by Bennett and others (1968) provides a means by which the results can be applied to many similar flow systems. Suitability of application of the dimensionless analysis is dependent upon the flow-net constant for the particular system under investigation. Even if the flow-net constant of the natural system is close to one of the three flow-net constants investigated by Bennett and others, general conclusions about well design and pumping rates can be made.

\section{Dimensionless Analysis of Brine Coning in the Montauk Area}

Flow-net constants for the Montauk area were calculated from assumed values for each variable in the flow-net constant equation, as outlined below.

$$
\text { Radius of influence }\left(r_{e}\right)=\sqrt{\frac{Q}{W \pi}}
$$

where we11 discharge $(Q)=300 \mathrm{gal} / \mathrm{min}$

$$
\begin{aligned}
& \text { recharge rate }(W)=4.05 \times 10^{-5} \mathrm{in} / \mathrm{min}(21.3 \mathrm{in} / \mathrm{yr}) \\
& \text { Flow-net constant }=\left(\frac{\mathrm{h}_{\mathrm{o}}}{\mathrm{r}_{\mathrm{e}}}\right)^{2} \frac{\mathrm{K}_{1}}{\mathrm{~K}_{\mathrm{z}}}
\end{aligned}
$$

where freshwater thickness $\left(h_{0}\right)=100 \mathrm{ft}$.

Anisotropy ratios $\mathrm{K}_{1} / \mathrm{K}_{2}$ of $3: 1$ and $10: 1$ were investigated, and $\mathrm{f} 1 \mathrm{ow}$-net constants were calculated to be 0.0079 and 0.0265 , respectively. Although anisotropy estimated by the numerical-model pumping-test analysis discussed earlier was $3: 1$, calculations of maximum permissible discharge were made from the $10: 1$ anisotropy because the applicable flow-net constant closely approximated the 0.0256 flow-net constant used in Bennett and others' (1968) analog studies. With the top of the screen set at $Z_{t} / h_{0}=0.95$ and the bottom of the screen set at the fractional elevation $Z_{b} / h_{o}=0.65$ (in this case $35 \mathrm{ft}$ below the initial water table), the maximum permissible drawdown is $4.9 \mathrm{ft}$ at a maximum permissible discharge of $235 \mathrm{gal} / \mathrm{min}$. With the screen bottom set at the fractional elevation of 0.85 ( $10 \mathrm{ft}$ of screen with the bottom set $15 \mathrm{ft}$ below the initial water table), the maximum permissible drawdown is $12.9 \mathrm{ft}$ at a discharge of $258 \mathrm{ga} 1 / \mathrm{min}$. 
The effects of varying screen length upon the flow lines, equipotential lines, and the level of saltwater upconing for a given flow-net constant is shown in figure 34. Dimensionless flow nets for the flow-net constant 0.0256 with the screen bottom set at a fractional elevation of 0.65 are shown in figure $34 \mathrm{~A}$ and with the screen bottom set at a fractional elevation of 0.85 in figure 34B. The most notable difference between these flow nets is the altitude of the stable brine cone at the two different screen settings. The shorter screen tends to concentrate the lines of equal head around the screen and also raises the altitude of the brine cone; it also increases the maximum permissible drawdown.

The relationship between the (dimensionless) screen-bottom altitude, $\mathrm{z}_{\mathrm{b}} / \mathrm{h}_{\mathrm{O}}$, and the (dimensionless) specific-capacity function, $\left[\frac{\mathrm{Q}}{\mathrm{h}_{\mathrm{o}} \mathrm{K}_{1}\left(\mathrm{~h}_{\mathrm{O}}-\mathrm{h}_{\mathrm{w}}\right)}\right]$, is shown in figure 35. The curves for each flow-net constant lie close to each other, indicating that specific capacity is less sensitive to the variables in the flow-net constant, such as original freshwater thickness and aquifer anisotropy, than to screen length.

A plot of dimensionless maximum permissible discharge, $\left(\frac{Q_{p f}}{\mathrm{~K}_{1} \mathrm{~h}_{\mathrm{o}}{ }^{2} \Delta_{\mathrm{p}}}\right)$,
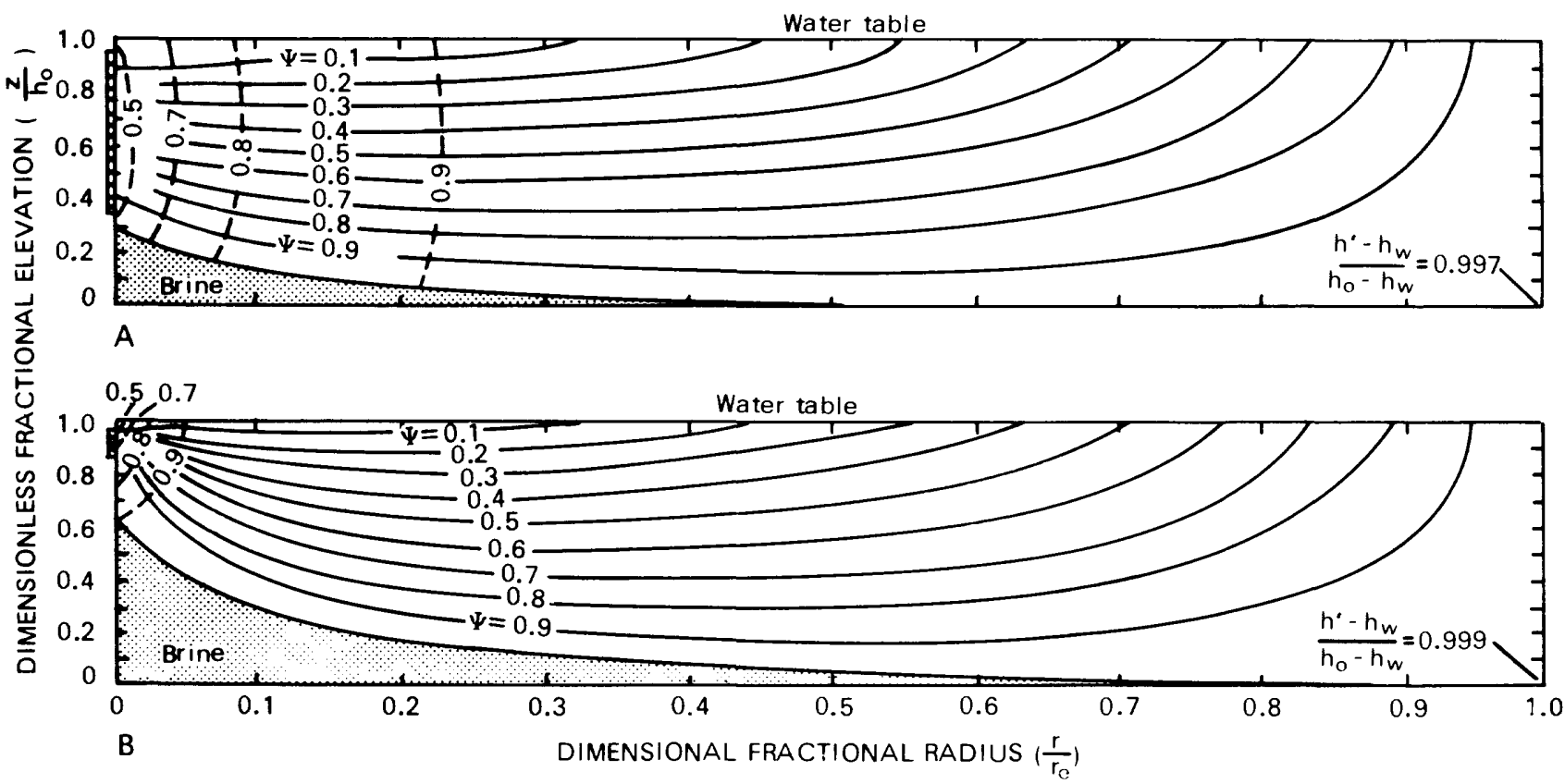

Figure 34.--Dimensionless flow nets for a flow-net constant of 0.0256 . A. Fractional screen elevation at 0.65 . B. At 0.85 . (Modified from Bennett and others, 1968.) 
in relation to the screen-bottom altitude, $z_{b} / h_{0}$, is shown in figure 36 . The maximum permissible discharge varies greatly from one value of the flow-net constant to another. Where the value of the flow-net constant is small, as in the Montauk area, the maximum permissible discharge does not vary significantly with screen-bottom altitude, as the sample calculations of maximum permissible discharge for two different screen settings that were presented earlier in the report indicate. Increasing the length of the screen by lowering the screen bottom $20 \mathrm{ft}$ decreased the maximum permissible discharge by only about $25 \mathrm{gal} / \mathrm{min}$.

\section{EXPLANATION TO FIGURE 34}

- $\Psi=0.1$ - Streamline, or intersection of stream surface with $r-z$ plane, where $\Psi$ is the stream function, a dimensionless term giving the fraction of the well discharge enclosed within the stream surface in question.

- $0.8-$ Line of equal head, or intersection of surface of equal head with $r-z$ plane, numbered according to the value of the dimensionless term $\frac{h-h_{w}}{h_{0}-h_{w}}$ along the surface in question, where: $h$ is the hydraulic head, measured above the level of the interface at $r_{e}$ as datum;

$h_{o}$ is the head of the water table at $r_{e}$ and the thickness of the freshwater at $r_{e}$; and

$h_{w}$ is the head along the face of the well screen.

$\frac{h^{\prime}-h_{w}}{h_{0}-h_{w}}$ indicates the value of $\frac{h-h_{w}}{h_{0}-h_{w}}$ at $\left(\frac{r}{r_{e}}=1, \frac{z}{h_{0}}=0\right)$. Screen top is at $\frac{z}{h_{0}}=0.95$ in both flownets. Fractional screen radius $\frac{r_{w}}{r_{e}}$, is $\frac{1}{2896}$ in both flownets. Both flownets have been plotted for a dimension ratio, $\frac{h_{0}}{r_{e}}$, of 0.173 .

We11 screen 


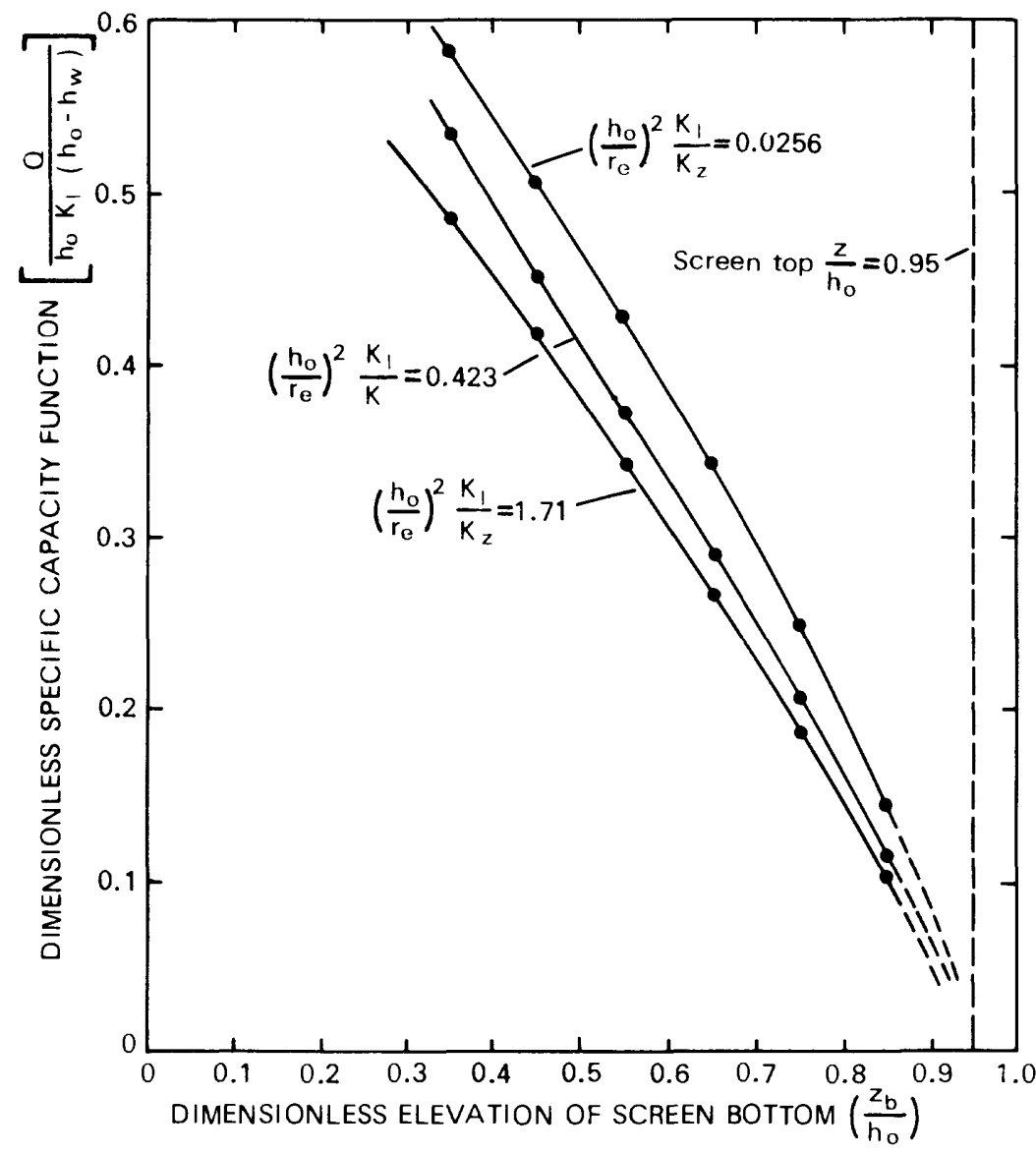

Figure 35 .

Dimensionless specificcapacity function, in relation to elevation of screen bottom, for conditions of maximum stable coning. (Modified from Benneti. and others, 1968.)

\section{Conclusions From the Dimensionless Analysis}

The analog studies and dimensionless equations can be a useful guide in determining well-construction specifications and pumping-management schemes. Dimensionless plots of Bennett and others (1968) in figures 34-36 seem to indicate that the aquifer characteristics and recharge rates of the Montauk area limit the number of variations in well design and operation. The freshwater lens in the Montauk area is relatively thin, which severely limits the maximum allowable pumping rate. Furthermore, the sample calculations presented here assume a ratio of horizontal to vertical hydraulic conductivity of about $10: 1$, but anisotropy in the Montauk area is closer to $3: 1$. The lower anisotropy allows relatively large vertical movement of water and a greater tendency to develop saltwater upconing.

The dimensionless flow-net plot in figure 34 suggests that the diameter of the well has little influence on brine-cone development, especially where a long screen is used. The ratio of $r_{w}$ to $r_{e}$ was fixed in the original model construction; thus, to assume a value for either $r_{w}$ or $r_{e}$ in the trial calculations is to fix the value of the other. The difficulty can be circumvented to some extent by visualizing a larger or smaller diameter well screen in figure 35. This would extend or reduce the horizontal parts of the flowlines near the well screen, causing a reduction or increase in the specific capacity of the well as different equipotential lines are intersected by the we11, but the overall flow pattern would not be affected. 


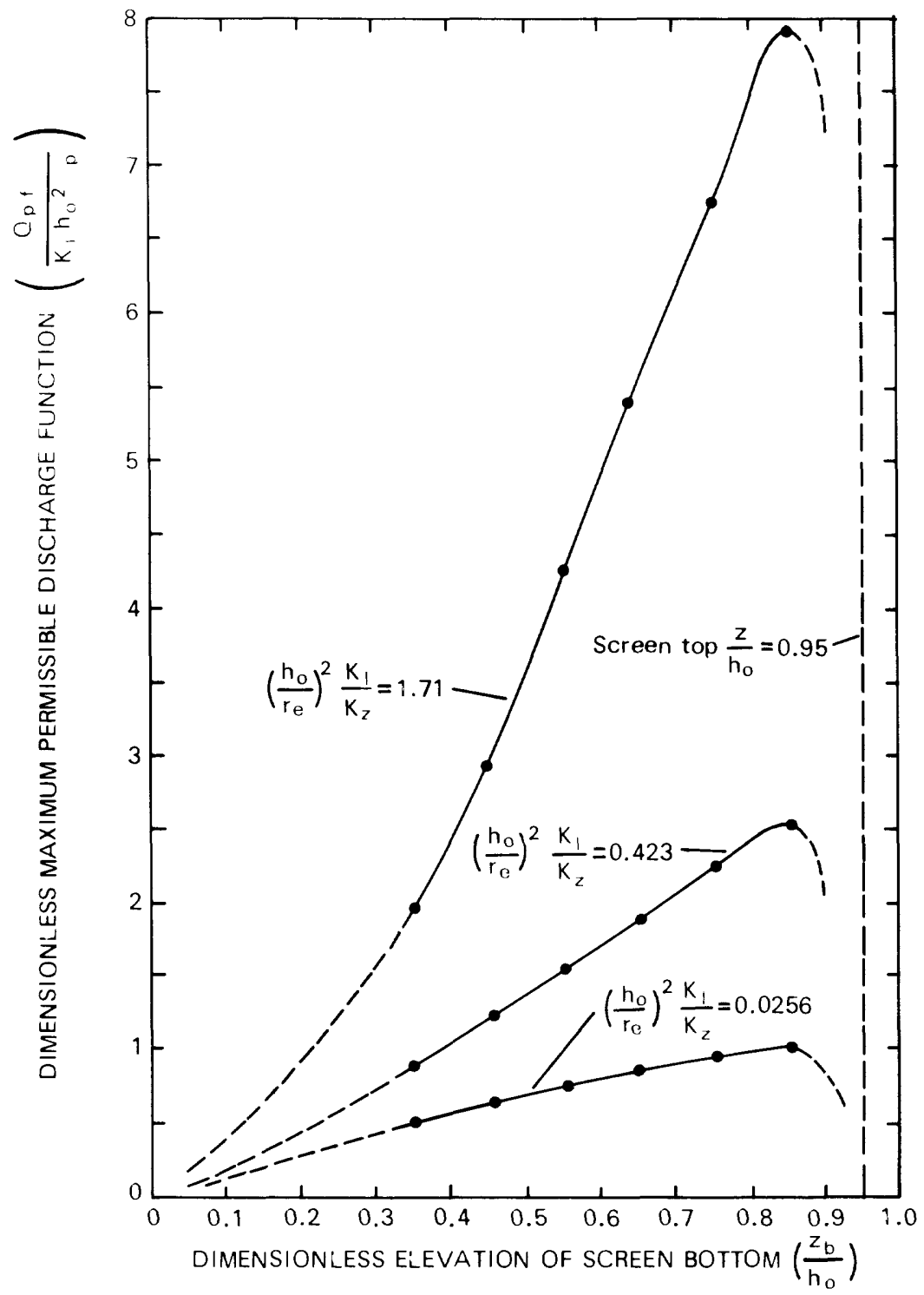

Figure 36.

Maximum permissible discharge function, Qf $\overline{K_{L} h_{0}{ }^{2} \Delta p}$, in relation to screenbottom altitude, $Z_{b} / h_{0}$. (Modified from Bennett and others, 1968).

The design specifications for the screen length of a well are commonly inflexible. In the analog studies by Bennett and others (1968), the top of the screen was chosen at a fractional elevation of 0.95 . Aquifer response and well-entrance losses may dictate a deeper setting for the top of the screen. Furthermore, efficiency of operation may require that the screen bottom be set deeper than the maximum permissible discharge would allow. For the Montauk area, where the flow-net constant is probably less than 0.0256 , the maximum permissible discharge does not decrease rapidly with deeper screen settings, but it is still desirable to set the screen top and bottom at the highest level consistent with the drawdown and well-entrance losses that will be encountered. Ideally, a large-diameter gravel pack should be installed around the screen to minimize wel1-entrance losses.

In addressing optimum well design and operation, water-supply managers must decide what withdrawal rate they wish to use. Peak pumpage and long-term average pumpage differ greatly. The water manager must decide whether the 
well design and operation should prevent movement of the freshwater/saltwater interface into the well screen or whether some upconing to the we11, through extended periods of time, would be permissible. The present design and operation of the public-supply wells in the area is causing an increase in chloride concentration in the wells.

Analysis of brine coning through the dimensionless plots provided by Bennett and others (1968) indicates that the design capacity of most present public-supply wells ( $300 \mathrm{gal} / \mathrm{min}$ ) exceeds the maximum permissible discharge for safe steady-state brine coning. Calculations presented earlier in this report yielded a maximum permissible discharge of $235 \mathrm{gal} / \mathrm{min}$ with a fractional screen zone from 0.65 to 0.95 of $h_{0}$ at an anisotropy of 10:1. For the Montauk area, anisotropy is probably closer to $3: 1$, in which case the maximum permissible discharge would be less than the calculated $235 \mathrm{gal} / \mathrm{min}$, but how much less is unknown.

\section{ASSESSMENT OF FRESHWATER AVAILABILITY}

Results of the model studies indicate that on a regional scale, sufficient freshwater is available to meet the needs of the projected 1995 permanent population, even under conditions of sustained peak stress. However, local saltwater upconing and continued elevation of chloride concentration at some wells may require consideration of alternative methods of developing the area's freshwater resources.

Freshwater beneath the Montauk area forms a relatively thin lens that floats on denser saline water. As on any island, drawdowns from pumping wells should be minimized because they produce localized upconing of salt water from below. To minimize upconing requires that the stress be widely distributed in what is commonly referred to as a "skimming" type of operation. This requires many low-capacity wells that are spread far enough apart that each has only a small cone of depression and that none of these overlap. In this way fresh water is skimmed from the top of the aquifer, and large cones of depression, strong vertical gradients, and the resulting saltwater upconing are avoided.

The simplest way to implement a skimming operation is to require an individual well for each residence and multiple wells for businesses that require large volumes of freshwater. Development in this manner will allow the maximum draft of fresh water.

An alternative to private wells for each residence and business is to continue expansion of the public-supply system to meet future water needs, a trend that has already begun. The design and siting of future wells must be carefully planned to minimize saltwater upconing, however. Numerical-model analyses of anticipated withdrawal rates indicate that if the stress is distributed over several wells instead of just one, unacceptable levels of saltwater upconing should not occur. Specific guidelines regarding well design and location are beyond the scope of this study, but some general conclusions can be inferred from the model results presented herein and from the analog-model studies of upconing by Bennett and others (1968). These general conclusions are summarized below. 


\section{Effects of Well Placement}

To minimize the possibility of saltwater contamination, the location of wells must be considered. Wells should be away from the shore, where practical, to reduce the risk of inducing movement of the saltwater toe toward the well. Locating wells within the central part of the landmass will place them where the freshwater aquifer thickness is greatest ( $\mathrm{fig} \cdot 16$ ).

A less obvious consideration for the location of wells is the hydrologic effect of the overlying till unit. Data from the pumping test of May 11-12, 1982, indicate that this unit acts as a confining layer to the principal aquifer. Confining the principal aquifer decreases the aquifer storativity, which in turn causes the effects of pumping stresses to propagate more quickly through the aquifer. This does not present a problem for development of freshwater resources when the supply wells are operated below the maximum rate for stable saltwater upconing under steady-state conditions, but if the wells are operated at a higher rate, even for short durations, upconing will occur more quickly than if the aquifer were unconfined.

The principal aquifer is confined throughout most of the Montauk area. However, the till unit is above the water table or absent in some sections of Hither Hills (fig. 5), so that transient upconing caused by seasonal excessive pumping may be less serious here than elsewhere. One Suffolk County Water Authority wel1, S51275, is in an area where the aquifer is unconfined and, unlike wells in areas that are confined, it shows no increase in chloride concentration through time. This indicates that wells should be located where the aquifer is unconfined so that upconing will be less sensitive to cyclic overpumping by supply wells.

\section{Effects of Well Design}

Well construction can be designed to minimize the possibility of saltwater upconing, as outlined in the section on "Site-Specific Considerations" (p. 78). Briefly, the bottom of the well screen should be set at the shallowest position that will provide an adequate discharge. The shallower the wel1 screen, the farther upward the saltwater cone must rise before it will be drawn into the well. Also, the diameter of the well screen can be increased, or a large gravel pack placed around the screen, to increase the specific capacity of the we11, possibly allowing a shallower placement of the screen bottom. Pumping rates must be kept low, even when the well is designed for optimum freshwater skimming. Sample calculations presented earlier, based on analog-model studies of saltwater upconing, indicate that a pumping rate as low as $200 \mathrm{gal} / \mathrm{min}$ may be enough to induce saltwater upconing in the Montauk area.

The preceding statments do not necessarily imply that all wells in the area should be designed to produce a condition of stable coning. For example, if wells are installed in areas where the principal aquifer is unconfined, the rate of saltwater movement toward a pumping well may be slow enough to allow intermittent pumping rates slightly in excess of the maximum permissible rate for stable saltwater coning. However, this is an engineering or water-management decision that may require future site-specific study. 


\section{Effects of Future Development}

The level of development in the Montauk area is low at present, but indications are that considerable land development will occur before 1995 . The increased population will place an additional demand on the ground-water system, and although freshwater will be available in sufficient quantity to meet the demand, the chemical quality of the water may be affected.

Most wastewater is currently disposed of through cesspools and septic tanks. Significant increases in population density will result in increased discharge of wastewater to the ground-water system, and, in view of the relatively thin layer of freshwater available and the necessarily shallow supply-well screen settings, wastewater entering the aquifer will eventually reach the pumping centers.

One possible measure to avoid contamination of the ground-water system by wastewater would be the installation of sanitary sewers. Sanitary sewers have been used in other areas of Long Island for many years with some success in abating contamination of ground water from cesspools and septic tanks (Ragone and others, 1981).

Treated wastewater from sewage-treatment plants elsewhere on Long Island is generally disposed of by ocean outfall, which reduces the quantity of water recharging the aquifer because it removes wastewater that would otherwise be returned to the system through septic tanks and cesspools. The effects of sanitary sewers upon ground-water levels in western Long Island has been well documented (Franke, 1968; Garber and Sulam, 1976; and Sulam, 1979). If water managers should decide to institute wastewater treatment and disposal on a large scale in the Montauk area, the effects of reduced recharge combined with increased pumpage to supply the needs of a growing population may result in overdraft and saltwater intrusion into the aquifer. Probably the only way in which sanitary sewers could be used in the Montauk area would be to treat the wastewater and return it to the aquifer through recharge basins and injection wells. A pilot study was conducted by the U.S. Geological Survey on Long Island to evaluate the effectiveness of returning highly treated wastewater to the aquifer through ponding basins (Aronson, 1980; Schneider and Oaksford, 1986; and Schneider and others, in press).

Before a decision to construct sanitary sewers is made, their effect on ground-water levels and freshwater thickness must be evaluated. If it is found that sanitary sewers can be operated only in conjunction with artificial recharge, then methods and the desirability of returning reclaimed wastewater to the aquifer must be evaluated.

\section{SUMMARY AND CONCLUSIONS}

Construction and development in the Montauk area is occurring at a rapid rate. This, combined with a large influx of seasonal vacationers, places a heavy demand for fresh ground water upon a public-supply system that is already experiencing elevated chloride concentrations at some wells. The freshwater resources of the Montauk area were investigated during 1980-83 to evaluate the present aquifer conditions and the potential for future development. 
Test drilling indicates that freshwater in the Montauk area occurs almost exclusively in deposits of pleistocene age. The principal aquifer and sole source of fresh ground water in the area is a deposit of fine- to coarsegrained stratified glacial drift. The aquifer is bounded on the bottom by a marine clay unit--possibly the Gardiners(?) Clay--and on the top by a discontinuous deposit known as the upper unit of undifferentiated till and stratified drift (the till unit), which generally has low permeability and locally confines the principal aquifer. In most places, the altitude of the base of freshwater is not more than $150 \mathrm{ft}$ below sea level, but the thickness of freshwater in the aquifer is limited by the marine clay unit at depths slightly higher than $100 \mathrm{ft}$ below sea level.

Test drilling has indicated that the zone of diffusion at the freshwater/ saltwater interface is generally not more than $20 \mathrm{ft}$ thick. Water samples from wells screened in the zone of diffusion or just above show no clear temporal trend in chloride concentration, which indicates that neither seasonal nor long-term regional movement of the interface has occurred as yet.

Precipitation, the sole source of freshwater in the area, averages from 41 to 43 inches per year. Direct runof $f$ is approximately 1 inch per year, and evapotranspiration is approximately 20 inches per year; the remaining 21 inches recharges the principal aquifer.

Hydraulic conductivity of the principal aquifer was estimated from specific-capacity data and an aquifer-pumping test. The average horizontal hydraulic conductivity as calculated from the specific-capacity data is about $250 \mathrm{ft} / \mathrm{d}$; the value calculated from graphical analysis and numerical flow modeling of the aquifer-pumping test indicates a value of between 270 and 280 $\mathrm{ft} / \mathrm{d}$, with a vertical hydraulic conductivity of approximately $90 \mathrm{ft} / \mathrm{d}$ and a storage coefficient between $1.1 \times 10^{-3}$ and $2.2 \times 10^{-3}$.

A numerical model to simulate areal flow of freshwater and saltwater was developed to evaluate both the present aquifer conditions and the potential for future development in the area. Model results indicate that, on a regional scale, the principal aquifer is capable of producing more than the nearly $0.6 \mathrm{Mgal} / \mathrm{d}$ currently being withdrawn for public supply and should be capable of supplying enough water to meet the needs of the population projected for 1995.

Analyses of chloride concentrations and pumpage for public-supply wells indicate a direct relationship between pumpage and elevated chloride levels, and linear-regression analysis of chloride concentrations over recent years shows an increasing trend. Even though model results indicate that the ground-water system has not been overdeveloped, the local increase in chloride is cause for future concern. On a regional basis the freshwater supply is sufficient, but the elevated chloride concentrations at specific sites can be avoided only through careful management of pumping rate and proper location, design, and spacing of future wells.

Dimensionless analysis of analog-model studies of saltwater upconing indicates that current management practices should be reevaluated. Although the analog-model studies are not directly transferable to the Montauk area owing to differences in aquifer characteristics, the following generalizations 
can be drawn: (1) extended withdrawals (longer than several hours per day) of $300 \mathrm{gal} / \mathrm{min}$ from individual wells are too great for safe development of the Montauk ground-water system; (2) wells should be designed with large-diameter screens with gravel packs so that the bottoms of the screens can be set at shallow depths without diminishing specific capacity; (3) dimensionless analysis of the analog studies cannot be used to determine the maximum safe discharge of supply wells in the area because of the area's unique hydrologic conditions; however, indications are that a pumping rate of less than 200 gal/min may be necessary to establish a stable saltwater cone beneath an optimally designed well.

Pumpage from public-supply wells increases sharply during the summer. The resulting transient saltwater upconing can be minimized by placing wells where the aquifer is not confined by the till unit. Drawdowns would be smaller for a given discharge; hence, the development of saltwater upconing would be less because of the high specific yield in the unconfined areas.

Sufficient freshwater is available in the Montauk area for the needs of the present and projected 1995 population of the area. With proper design and development of supply wells, draft on the system could be increased without causing saltwater intrusion. However, additional study of saltwater upconing beneath public-supply wells in the area would be needed to define the optimum design, location, and rate of pumping for future public-supply wells.

\section{REFERENCES CITED}

Aronson, D. A., 1980, The Meadowbrook artificial-recharge project in Nassau County, Long Island, New York: Long Island Water Resources Bulletin 14, 23 p.

Bart, J., Blank, P., Buscheck, T., Furlong, E., Hsieh, P., Pollack, A., Shapiro, A., and Wolahan, J., 1976, Preliminary hydrologic investigations of the south fork of Long Island: Princeton, N.J., Princeton University Water Resources Program Report WRP 76-1, p. Al-G36.

Bennett, G. D., Mundorff, M. J., and Hussain, S. A., 1968, Electric-analog studies of brine coning beneath freshwater wells in the Punjab Region, West Pakistan: U.S. Geological Survey Water-Supply Paper 1608-J, 31 p.

Bredehoeft, J. D., 1963, Hydrogeology of the lower Humboldt River basin, Nevada: Desert Research Institute, Nevada University, Technical Report $3,50 \mathrm{p}$.

Burns, A. W., Frimpter, H. M., and Willey, E. R., 1975, Evaluation of data availability and examples of modeling for ground-water management on Cape Cod, Massachusetts: U.S. Geological Survey Water-Resources Investigations $75-16,22 \mathrm{p}$.

Cohen, Philip, Franke, 0. L., and Foxworthy, B. L., 1968, An atlas of Long Island's water resources: New York State Water Resources Commission Bulletin 62, 117 p. 


\section{REFERENCES CITED (continued)}

Fetter, C. W., Jr., 1971, Hydrogeology of the south fork of Long Island, New York: Bloomington, Ind., Indiana University, unpublished doctoral dissertation, $236 \mathrm{p}$.

1976, Hydrogeology of the south fork of Long Island, New York: Geological Society of America Bulletin, v. 87, p. 401-406.

Franke, 0. L., 1968, Double-mass curve analysis of the effects of sewering on ground-water levels on Long Island, New York, in Geological Survey Research, 1968: U.S. Geological Survey Professional Paper 600-B, p. B 205-B209.

Franke, O. L., and McClymonds, N. E., 1972, Summary of the hydrologic situation on Long Island, New York, as a guide to water-management alternatives: U.S. Geological Survey Professional Paper 627-F, 59 p.

Fuller, M. L., 1914, The geology of Long Island, New York: U.S. Geological Survey Professional Paper 82, 231 p.

Garber, M. S., and Sulam, D. J., 1976, Factors affecting declining water levels in a sewered area of Nassau County, New York: U.S. Geological Survey Journal of Research, v. 4, no. 3, p. 255-265.

Holzmacher, McLendon, and Murrel1, 1968, Comprehensive public water supply study, Suffolk County, New York: Melville, N.Y., CPWS-24, 3 v.

Hsieh, P. 1977, Simulation of salt-water upconing beneath a pumping we11: Princeton, N.J., Princeton Water Kesources Program Report 77-WRP, 84 p.

Jensen, H. M., and Soren, Julian, 1974, Hydrogeology of Suffolk County, Long Island, New York: U.S. Geological Survey Hydrologic Investigations Atlas HA-501, 2 sheets.

Konikow, L. F., 1978, Calibration of ground-water models, in Proceedings of the speciality conference on verification of mathematical and physical models in hydraulic engineering: American Society of Civil Engineers, p. 87-93.

Linsley, R. K., Jr., Kohler, M. A., and Paulhus, J. L., 1975, Hydrology for Engineers: New York, McGraw-Hil1, p. 182.

Lohman, S. W., 1972, Ground-water hydraulics: U.S. Geological Survey Professional Paper 708, 70 p.

Long Island Regional Planning Board, 1978, Long Island Comprehensive waste treatment management plan, volume II, Summary documentation: NassauSuffolk Regional Planning Board, 364 p.

Lusczynski, N. J., 1961, Filter-press method of extracting water samples for chloride analysis: U.S. Geological Survey Water-Supply Paper 1544-A, $8 \mathrm{p}$. 


\section{REFERENCES CITED (continued)}

McClymonds, N. E., and Franke, O. L., 1972, Water-transmitting properties of aquifers on Long Island, New York: U.S. Geological Survey Professional Paper 627-E, 24 p.

Mercer, J. W., Larson, S. P., and Faust, C. R., 1980, Finite-difference model to simulate the areal flow of saltwater and freshwater separated by an interface: U.S. Geological Survey Open-File Report 80-407, 83 p.

Meyer, A. F., 1928, The elements of hydrology: New York, John Wiley, 522 p.

Miller, J. F., and Frederick, R. H., 1969, The precipitation regime of Long Island, New York: U.S. Geological Survey Professional Paper 627-A, $21 \mathrm{p}$.

Muskat, Morris, 1937 [reprinted 1946], The flow of homogeneous fluids through porous media: Ann Arbor, Mich., J. W. Edwards, Inc., p. 487-490.

National Oceanic and Atmospheric Administration, 1972-81, C1imatological data, annual summary: v. 84 , no. $13 ; \mathrm{v} .93$, no. 13 .

Nemickas, Bronius, and Koszalka, E. J., 1982, Geohydrologic appraisal of water resources of the south fork, Long Island, New York: U.S. Geological Survey Water-Supply Paper 2073, 56 p.

Nemickas, Bronius, Koszalka, E. J., and Vaupel, D. E., 1977, Hydrogeologic data from investigation of water resources of the south fork, Suffolk County, Long Island, New York: Long Island Water Resources Bulletin 7, $31 \mathrm{p}$.

Nieter, William, Nemickas, Bronius, Koszalka, E. J., and Newman, W. S., 1975, The Late Quaternary geology of the Montauk Peninsula--Montauk Point to Southampton, Long Island, New York, in M. P., Wolff, ed., New York State Geological Association Guidebook, $47 \overline{\mathrm{th}}$ anniversary meeting: Hofstra University, p. 129-156.

Perlmutter, N. M., and Deluca, F. A., 1963, Availability of fresh ground water, Montauk Point area, Suffolk County, Long Island, New York: U.S. Geological Survey Water-Supply Paper 1613-B, 39 p.

Ragone, S. E., Katz, B. G., Kimme1, G. E., and Lindner, J. B., 1981, Nitrogen in ground water and surface water from sewered and unsewered areas, Nassau County, Long Island, New York: U.S. Geological Survey WaterResources Investigations 80-21, $64 \mathrm{p}$.

Reilly, T. E., 1984, A Galerkin finite-element flow model to predict the transient response of a radially symmetric aquifer: U.S. Geological Survey Water-Supply Paper 2198, 33 p.

Schneider, B. J., and Oaksford, E. T., 1986, Design, operation, and monitoring capability of an experimental artificial-recharge facility at East Meadow, Long Island, New York: U.S. Geological Survey Water-Resources Investigations Report 84-4321, 46 p. 


\section{REFERENCES CITED (continued)}

Schneider, B. J., Ku, H. H. H., and Oaksford, E. T., Hydrologic effects of artificial-recharge experiments with reclaimed water at East Meadow, Long Island, New York: U.S. Geological Survey Water-Resources Investigations Report 85-4323 (in press).

Soren, Julian, 1978, Hydrogeologic conditions in the Town of She1ter Island, Suffolk County, Long Island, New York: U.S. Geological Survey WaterResources Investigations 77-77, 22 p.

Stallman, R. W., 1963, Electric analog of three-dimensional flow to wells and its application to unconfined aquifers: U.S. Geological Survey WaterSupply Paper 1536-H, p. 205-242.

Sulam, D. J., 1979, Analysis of changes in ground-water levels in a sewered and an unsewered area of Nassau County, Long Island, New York: Ground Water, v. 17 , no. 5, p. 446-455.

Suter, Russe11, DeLaguna, Wallace, and Perlmutter, N. M., 1949, Mapping of geologic formations and aquifers of Long Island, New York: New York State Water Power and Control Commission Bulletin GW-18, 181 p.

Thornthwaite, C. W., and Mather, J. R., 1955, The water balance: Drexe1 Institute of Technology, Publications in Climatology, v. 8, no. 1, p. $1-86$.

1957, Instructions and tables for computing potential evapotranspiration and the water balance: Drexel Institute of Technology, Publications in Climatology, v. 10, no. 3, $311 \mathrm{p}$.

U.S. Bureau of the Census, 1982, 1980 Census of population: U.S. Department of Commerce, v. 1, chapter A, part 34. (Issued February 1982.)

U.S. Envi ronmental Protection Agency, 1975, National interim primary drinkingwater regulations, in Federal Register: U.S. Envi ronmental Protection Agency Water Programs, part IV, v. 40, no. 246, p. 59566-59588.

Warren, M. A., DeLaguna, Wallace, and Lusczynski, N. J., 1968, Hydrology of Brookhaven National Laboratory and vicinity, Suffolk County, New York. U.S. Geological Survey Bulletin 1156-C, p. C21-C27. 
Table 11.-Water levels in the Montauk area, Long Island, N.Y.

[Well locations are shown in pl. 1; water levels are in feet above sea level; some measurements from Suffolk County Department of Health Services.]

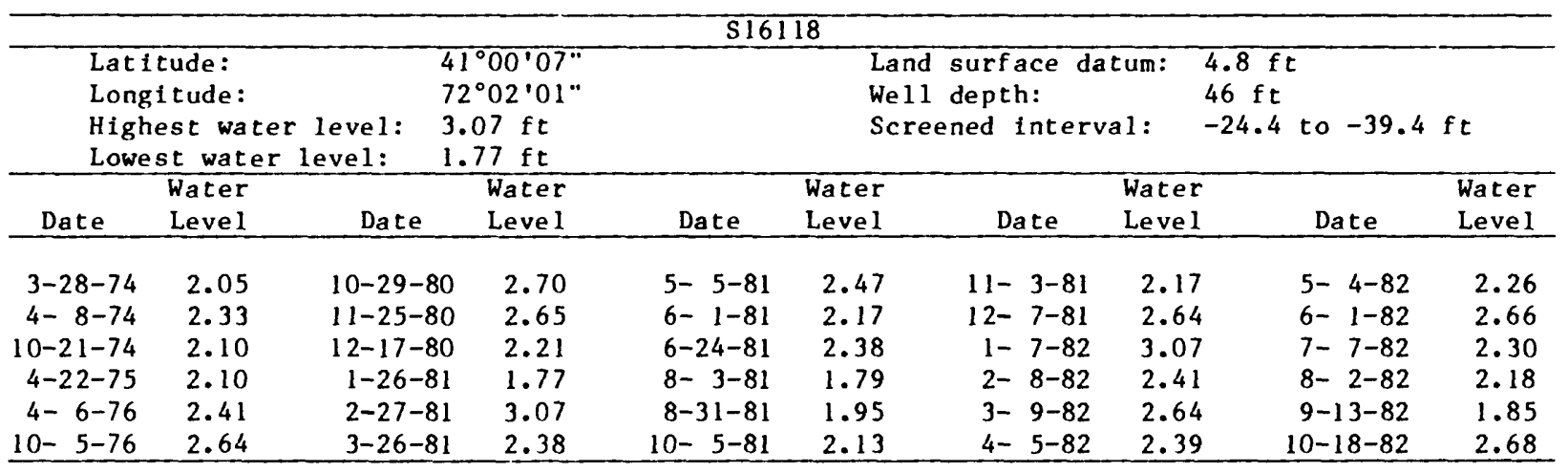

$\$ 48519$

\begin{tabular}{|c|c|c|c|c|c|c|c|c|c|}
\hline \multicolumn{3}{|c|}{$\begin{array}{l}\text { Latitude: } \\
\text { Longitude: } \\
\text { Highest water level: } \\
\text { Lowest water level: }\end{array}$} & $\begin{array}{l}41^{\circ} 02^{\prime} 43^{\prime \prime} \\
71^{\circ} 56^{\prime} 01^{\prime \prime} \\
3.96 \\
2.07\end{array}$ & & \multicolumn{3}{|c|}{$\begin{array}{l}\text { Land surface datum: } \\
\text { Well depth: } \\
\text { Screened interval: }\end{array}$} & \multicolumn{2}{|c|}{$\begin{array}{l}63.5 \mathrm{ft} \\
82 \mathrm{ft} \\
-6.2 \text { to }-16.2 \mathrm{ft}\end{array}$} \\
\hline Date & $\begin{array}{l}\text { Water } \\
\text { Leve } 1\end{array}$ & Date & $\begin{array}{l}\text { Water } \\
\text { Level }\end{array}$ & Date & $\begin{array}{l}\text { Water } \\
\text { Level }\end{array}$ & Date & $\begin{array}{l}\text { Water } \\
\text { Level }\end{array}$ & Date & $\begin{array}{l}\text { Water } \\
\text { Leve } 1\end{array}$ \\
\hline $1-8-74$ & 2.73 & $4-21-75$ & 2.80 & $4-14-78$ & 3.32 & $12-17-80$ & 2.42 & $10-5-81$ & 2.40 \\
\hline $2-27-74$ & 2.74 & $6-9-75$ & 3.23 & $1-3-79$ & 2.86 & $1-26-81$ & 2.44 & $11-3-81$ & 2.30 \\
\hline $3-23-74$ & 2.82 & $9-26-75$ & 2.89 & $3-7-79$ & 3.96 & $2-27-81$ & 2.67 & $12-7-81$ & 2.55 \\
\hline $5-8-74$ & 2.97 & $12-23-75$ & 3.14 & $6-19-79$ & 3.12 & $3-5-81$ & 2.87 & $1-7-82$ & 2.83 \\
\hline $6-3-74$ & 3.08 & $4-8-76$ & 3.12 & $9-17-79$ & 2.69 & $3-26-81$ & 2.63 & $3-9-82$ & 2.74 \\
\hline $7-15-74$ & 2.88 & $6-22-76$ & 2.56 & $12-27-79$ & 2.78 & $5-5-81$ & 2.80 & $4-5-82$ & 2.51 \\
\hline $8-14-74$ & 2.67 & $10-7-76$ & 2.96 & $3-13-80$ & 2.13 & $6-1-81$ & 2.50 & $5-4-82$ & 2.60 \\
\hline $9-23-74$ & 2.59 & $12-22-76$ & 2.07 & $6-15-80$ & 2.91 & $6-17-81$ & 2.62 & $6-1-82$ & 2.82 \\
\hline $10-15-74$ & 2.63 & $3-25-77$ & 2.88 & $9-12-80$ & 2.41 & $6-24-81$ & 2.50 & $7-7-82$ & 3.12 \\
\hline $10-23-74$ & 2.51 & $6-20-77$ & 2.87 & $10-29-80$ & 2.36 & $8-3-81$ & 2.32 & $8-2-82$ & 3.00 \\
\hline $10-31-74$ & 2.51 & $9-27-77$ & 3.13 & $11-26-80$ & 2.49 & $8-31-81$ & 2.42 & $9-13-82$ & 2.49 \\
\hline $\begin{array}{l}2-3-75 \\
2-18-75\end{array}$ & 2.65 & $12-12-77$ & 3.00 & $12-4-80$ & 2.28 & $9-22-81$ & 2.53 & $10-18-82$ & 2.81 \\
\hline
\end{tabular}

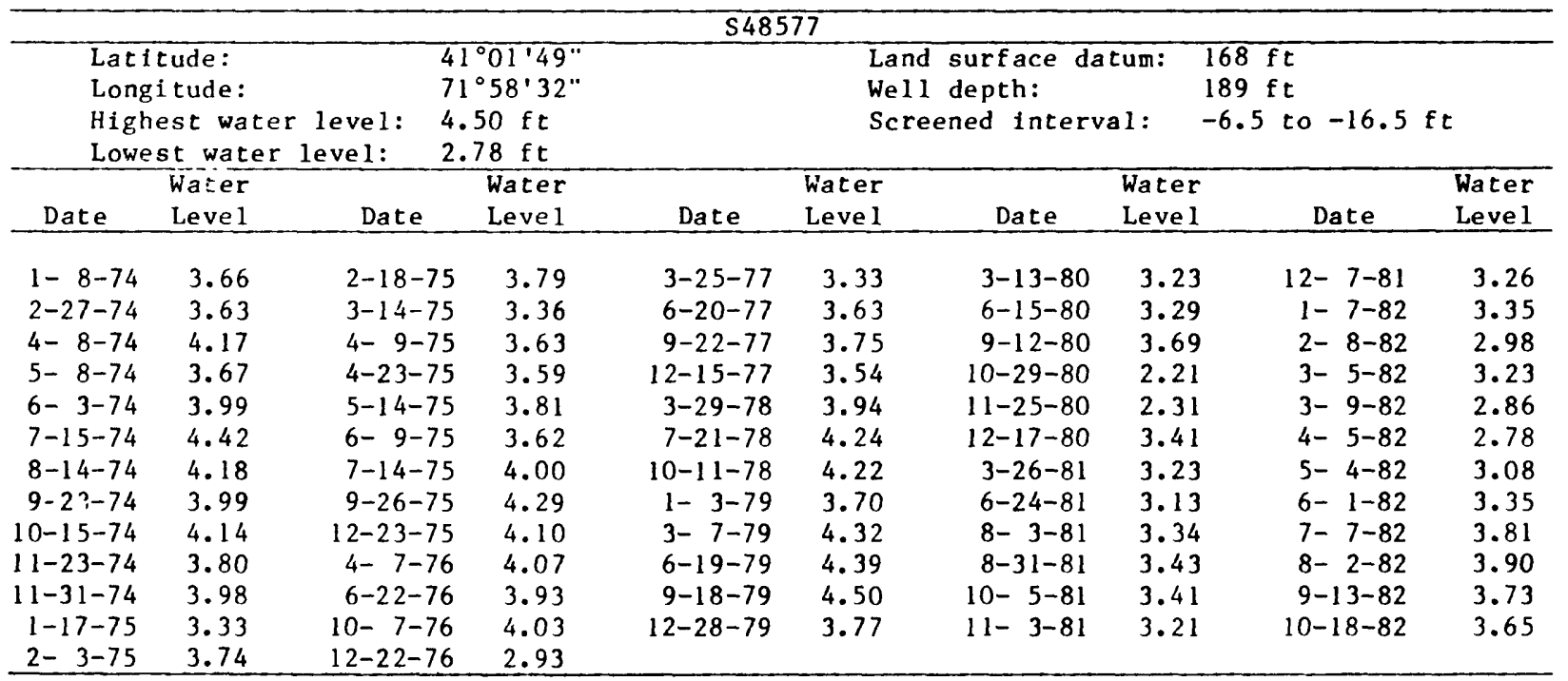


Table 11.--Water levels in the Montauk area, Long Island, N.Y.--continued

[Well locations are shown in pl. 1; water levels are in feet above sea level; some measurements from Suffolk County Department of Health Services.]

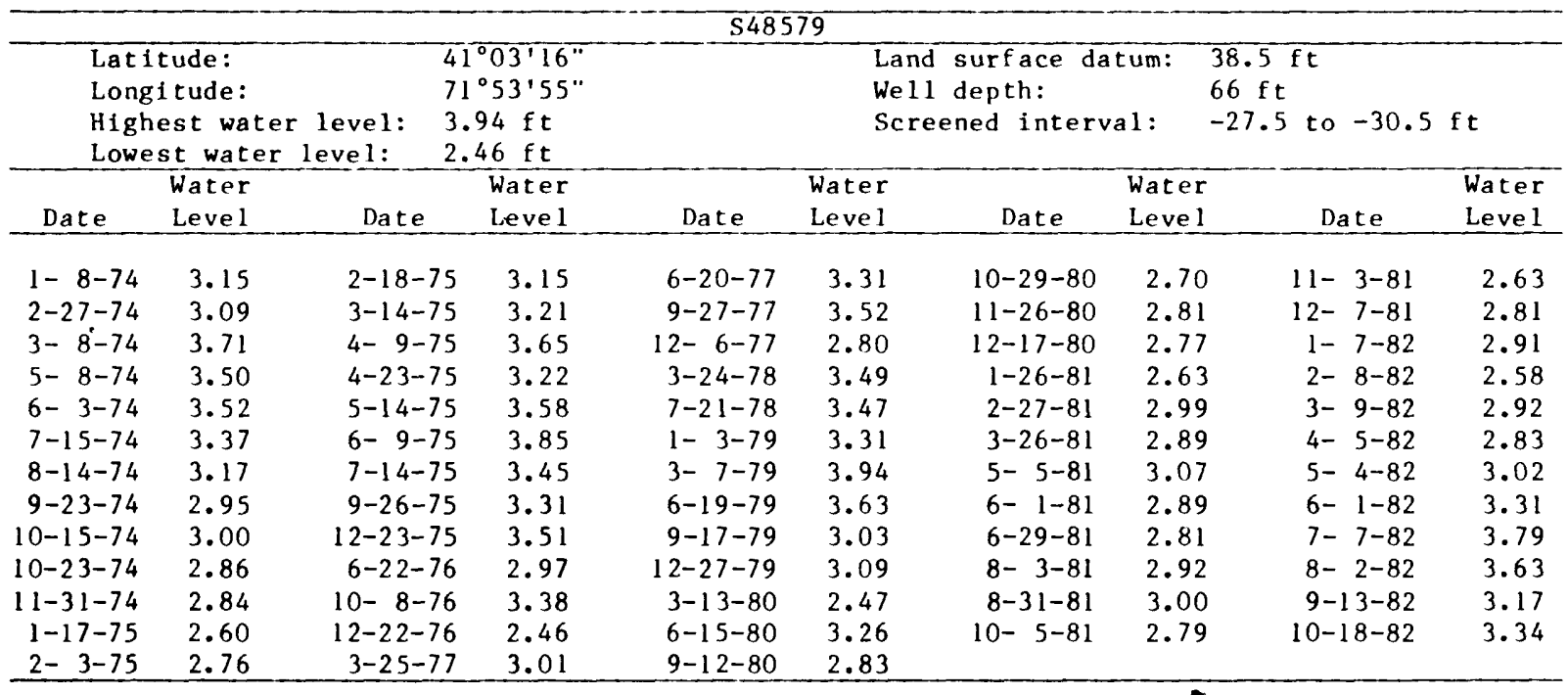

S58921

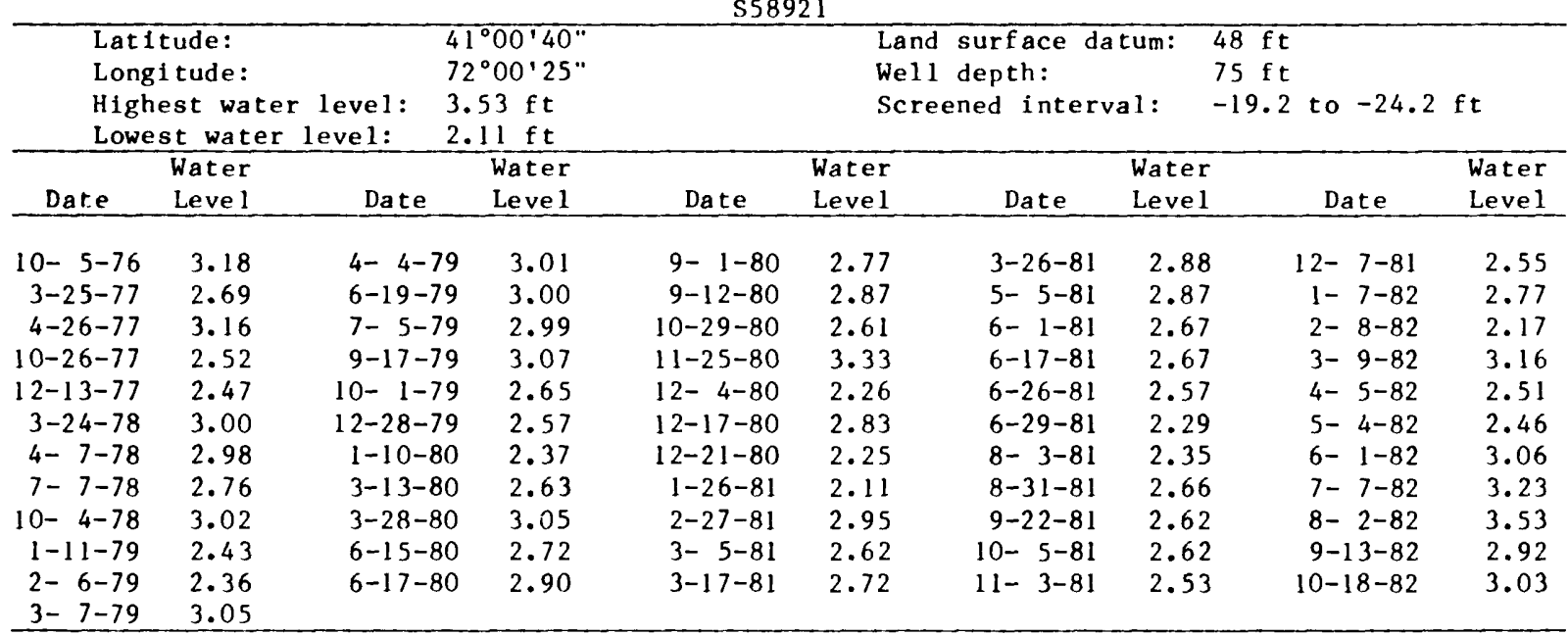

558922

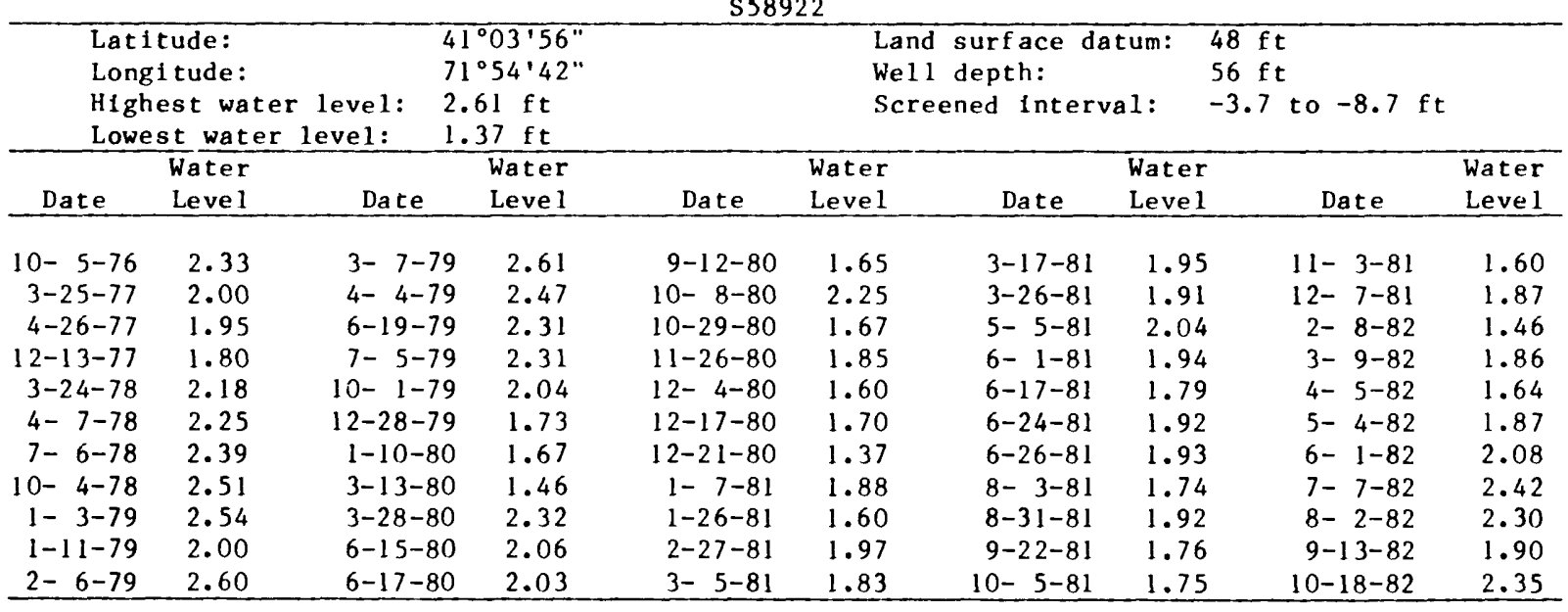


Table 11.-Water levels in the Montauk area, Long Island, N.Y.--continued

[Well locations are shown in pl. I; water levels are in feet ahove sea level; some measurements from Suffolk County Department of Health Services.]

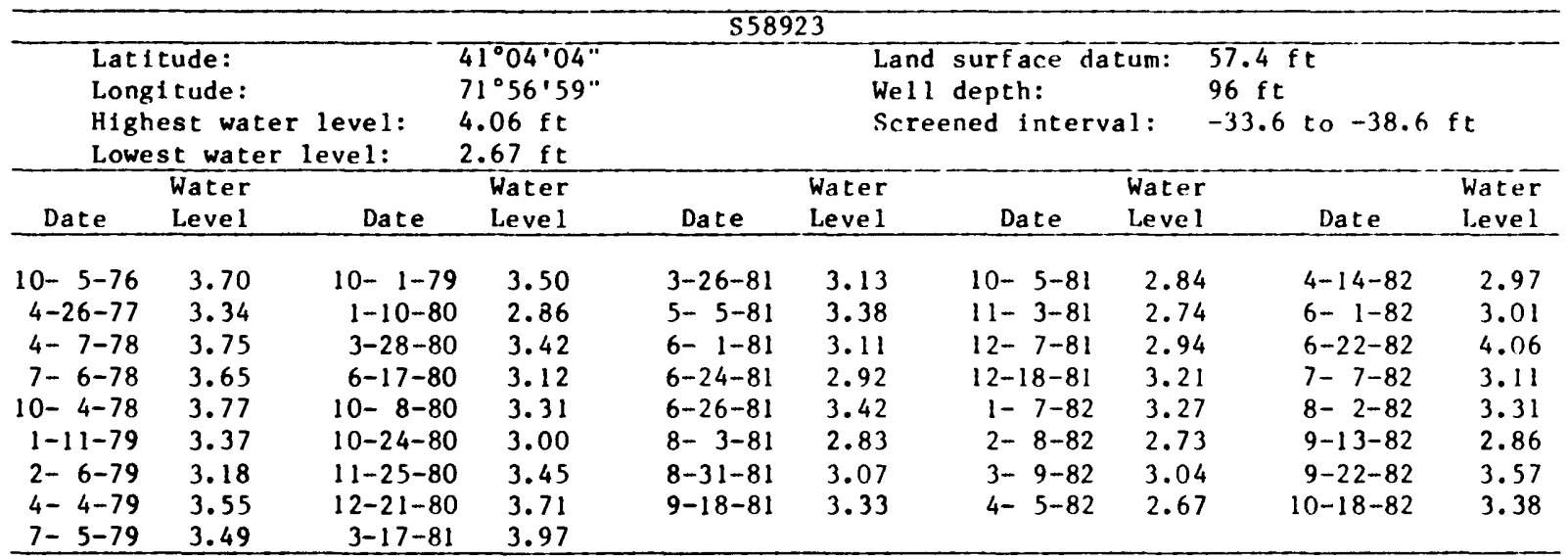

562397

\begin{tabular}{|c|c|c|c|c|c|c|c|c|c|}
\hline \multicolumn{3}{|c|}{$\begin{array}{l}\text { Latitude: } \\
\text { Longltude: } \\
\text { Highest water level: } \\
\text { Lowest water leve1: }\end{array}$} & $\begin{array}{l}41^{\circ} 01^{\prime} 09^{\prime \prime} \\
72^{\circ} 01^{\prime} 03^{\prime \prime} \\
5.16 \mathrm{ft} \\
1.98 \mathrm{ft} \\
\text { Water }\end{array}$ & & \multicolumn{3}{|c|}{$\begin{array}{l}\text { Land surface datum: } \\
\text { We11 depth: } \\
\text { Screened Interva1: }\end{array}$} & $\begin{array}{l}57.2 \mathrm{ft} \\
65 \mathrm{ft} \\
-4 \text { to }-8 \mathrm{ft}\end{array}$ & \multirow[b]{2}{*}{$\begin{array}{l}\text { Water } \\
\text { Level }\end{array}$} \\
\hline Date & $\begin{array}{l}\text { Water } \\
\text { Leve1 }\end{array}$ & Date & $\begin{array}{l}\text { Water } \\
\text { Leve l } \\
\end{array}$ & Date & $\begin{array}{l}\text { Water } \\
\text { Leve } 1 \\
\end{array}$ & Date & $\begin{array}{l}\text { Water } \\
\text { Leve } 1\end{array}$ & Date & \\
\hline $\begin{array}{r}12-17-80 \\
1-26-81 \\
2-27-81 \\
3-26-81 \\
5-5-81\end{array}$ & $\begin{array}{l}1.98 \\
2.70 \\
2.79 \\
3.01 \\
3.03\end{array}$ & $\begin{array}{r}6-1-81 \\
6-24-81 \\
8-3-81 \\
8-31-81 \\
10-5-81\end{array}$ & $\begin{array}{l}3.12 \\
3.14 \\
2.95 \\
2.85 \\
2.81\end{array}$ & $\begin{array}{r}11-3-81 \\
12-7-81 \\
1-7-82 \\
2-8-82\end{array}$ & $\begin{array}{l}2.70 \\
2.89 \\
2.73 \\
2.88\end{array}$ & $\begin{array}{l}3-9-82 \\
4-5-82 \\
5-4-82 \\
6-1-82\end{array}$ & $\begin{array}{l}3.16 \\
3.27 \\
3.26 \\
3.46\end{array}$ & $\begin{array}{r}7-7-82 \\
8-2-82 \\
9-13-82 \\
10-18-82\end{array}$ & $\begin{array}{l}5.16 \\
4.73 \\
4.05 \\
3.90\end{array}$ \\
\hline
\end{tabular}

S70256

\begin{tabular}{|c|c|c|c|c|c|c|c|c|c|c|}
\hline $\begin{array}{l}\text { Lat } 1 \\
\text { Long } \\
\text { High } \\
\text { Lowe }\end{array}$ & $\begin{array}{l}\text { tude: } \\
\text { itude: } \\
\text { est water } \\
\text { st water }\end{array}$ & $\begin{array}{l}\text { level: } \\
\text { level: }\end{array}$ & $\begin{array}{l}\circ 02^{\prime} 00^{\prime \prime} \\
00 ' 16^{\prime} \\
89 \mathrm{ft} \\
97 \mathrm{ft}\end{array}$ & & & $\begin{array}{l}\text { rface da } \\
\text { pth: } \\
\text { d interv }\end{array}$ & $\begin{array}{l}\text { tum: } \\
\text { a1: }\end{array}$ & $\begin{array}{l}67 \mathrm{ft} \\
175 \mathrm{f} \\
-97 \mathrm{t}\end{array}$ & $\mathrm{t}-102 \mathrm{ft}$ & \\
\hline Date & $\begin{array}{l}\text { Water } \\
\text { Level } \\
\end{array}$ & Date & $\begin{array}{l}\text { Water } \\
\text { Level }\end{array}$ & Date & $\begin{array}{l}\text { Water } \\
\text { Level }\end{array}$ & Date & $\begin{array}{l}\text { Water } \\
\text { Leve } 1 \\
\end{array}$ & & Date & $\begin{array}{l}\text { Water } \\
\text { Leve } 1 \\
\end{array}$ \\
\hline $\begin{array}{l}1-26-81 \\
2-27-81 \\
3-26-81 \\
5-5-81 \\
6-1-81\end{array}$ & $\begin{array}{l}0.97 \\
1.23 \\
1.30 \\
1.30 \\
1.44\end{array}$ & $\begin{array}{r}6-24-81 \\
8-3-81 \\
8-31-81 \\
10-5-81\end{array}$ & $\begin{array}{l}1.50 \\
1.41 \\
1.46 \\
1.35\end{array}$ & $\begin{array}{r}11-3-81 \\
12-7-81 \\
1-7-82 \\
2-8-82\end{array}$ & $\begin{array}{l}1.17 \\
1.40 \\
1.20 \\
0.99\end{array}$ & $\begin{array}{l}3-9-82 \\
4-5-82 \\
5-4-82 \\
6-1-82\end{array}$ & $\begin{array}{l}1.17 \\
1.21 \\
1.34 \\
2.47\end{array}$ & & $\begin{array}{r}7-7-82 \\
8-2-82 \\
9-13-82 \\
10-18-82\end{array}$ & $\begin{array}{l}3.89 \\
3.55 \\
2.15 \\
2.23\end{array}$ \\
\hline
\end{tabular}

S70257

\begin{tabular}{|c|c|c|c|c|c|c|c|c|c|}
\hline \multicolumn{3}{|c|}{$\begin{array}{l}\text { Latitude: } \\
\text { Longitude: } \\
\text { Highest water level: } \\
\text { Lowest water level: }\end{array}$} & $\begin{array}{l}41^{\circ} 01^{\prime} 08^{\prime \prime} \\
71^{\circ} 58.59^{\prime \prime} \\
3.68 \mathrm{ft} \\
1.33 \mathrm{ft}\end{array}$ & & \multicolumn{3}{|c|}{$\begin{array}{l}\text { Land surface datum: } \\
\text { Well depth: } \\
\text { Screened interval: }\end{array}$} & \multicolumn{2}{|c|}{$\begin{array}{l}50 \mathrm{ft} \\
113 \mathrm{ft} \\
-54.1 \text { to }-59.1 \mathrm{ft}\end{array}$} \\
\hline Date & $\begin{array}{l}\text { Water } \\
\text { Level }\end{array}$ & Date & $\begin{array}{l}\text { Water } \\
\text { Level }\end{array}$ & Date & $\begin{array}{l}\text { Water } \\
\text { Level }\end{array}$ & Date & $\begin{array}{l}\text { Water } \\
\text { Leve } 1\end{array}$ & Date & $\begin{array}{l}\text { Water } \\
\text { Leve } 1\end{array}$ \\
\hline $\begin{array}{l}5-5-81 \\
6-1-81 \\
6-29-81 \\
8-3-81 \\
\end{array}$ & $\begin{array}{l}3.68 \\
3.24 \\
2.90 \\
3.13 \\
\end{array}$ & $\begin{array}{r}8-31-81 \\
10-5-81 \\
11-3-81 \\
12-7-81 \\
\end{array}$ & $\begin{array}{l}2.75 \\
2.38 \\
2.01 \\
1.92 \\
\end{array}$ & $\begin{array}{l}1-7-82 \\
2-8-82 \\
3-9-82 \\
4-5-82 \\
\end{array}$ & $\begin{array}{l}2.07 \\
1.33 \\
2.94 \\
1.68 \\
\end{array}$ & $\begin{array}{l}5-4-82 \\
6-1-82 \\
7-7-82\end{array}$ & $\begin{array}{l}2.03 \\
2.58 \\
2.10\end{array}$ & $\begin{array}{r}8-2-82 \\
9-13-82 \\
10-18-82\end{array}$ & $\begin{array}{l}2.54 \\
2.23 \\
2.63\end{array}$ \\
\hline
\end{tabular}


T'able 11.--Water levels in the Montauk area, Long Island, N.Y.--continued

[Well locations are shown in pl. 1; water levels are in feet above sea level; some measurements from Suffolk County Department of Health Services.]

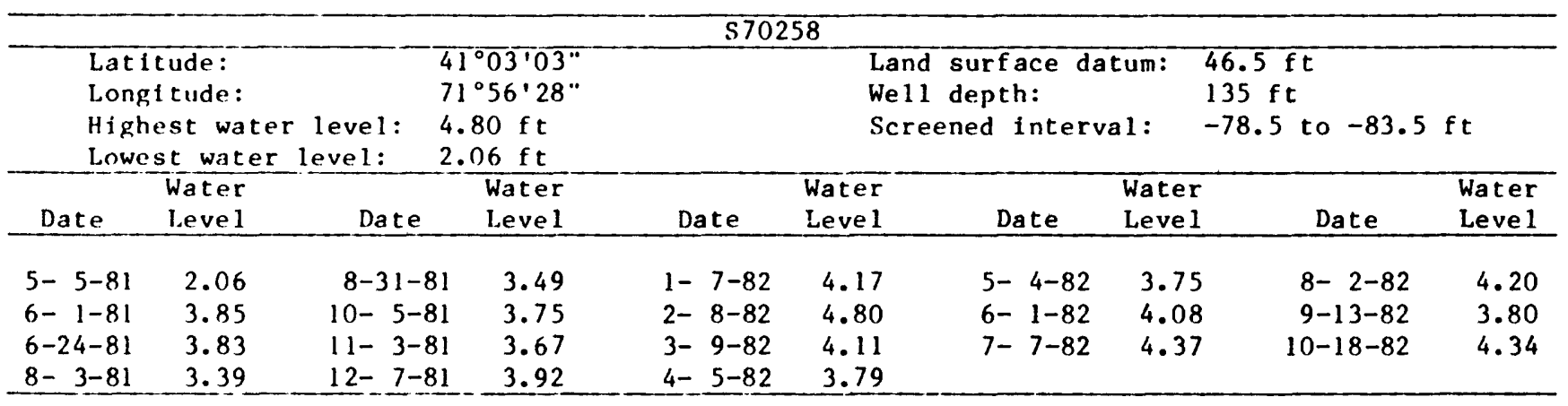

S 70259

\begin{tabular}{|c|c|c|c|c|c|c|c|c|c|}
\hline \multicolumn{2}{|c|}{$\begin{array}{l}\text { Lat i tude: } \\
\text { Longt tude: }\end{array}$} & $\begin{array}{rr} & 4 \\
\text { leve 1: } & 3 \\
\text { leve 1: } \quad 1 \\
\end{array}$ & $\begin{array}{l}41^{\circ} 02^{\prime} 32^{\circ} \\
71^{\circ} 55^{\circ} 37^{\circ} \\
3.13 \mathrm{ft} \\
1.67 \mathrm{ft}\end{array}$ & & \multicolumn{3}{|c|}{$\begin{array}{l}\text { Land surface datum: } \\
\text { We11 depth: } \\
\text { Screened interval: }\end{array}$} & $\begin{array}{l}39.0 \mathrm{ft} \\
102 \mathrm{ft}\end{array}$ & $\mathrm{ft}$ \\
\hline Date & $\begin{array}{l}\text { Water } \\
\text { Leve } 1\end{array}$ & Date & $\begin{array}{l}\text { Water } \\
\text { Leve } 1\end{array}$ & Date & $\begin{array}{l}\text { Water } \\
\text { Leve } 1 \\
\end{array}$ & Date & $\begin{array}{l}\text { Water } \\
\text { Level } \\
\end{array}$ & Date & $\begin{array}{l}\text { Water } \\
\text { Leve1 } \\
\end{array}$ \\
\hline $\begin{array}{l}5-5-81 \\
6-1-81 \\
6-24-81 \\
8-3-81\end{array}$ & $\begin{array}{l}2.33 \\
2.01 \\
2.35 \\
2.21\end{array}$ & $\begin{array}{r}8-31-81 \\
10-5-81 \\
11-3-81 \\
12-7-81\end{array}$ & $\begin{array}{l}2.23 \\
2.19 \\
2.09 \\
2.05\end{array}$ & $\begin{array}{l}1-7-82 \\
2-8-82 \\
3-9-82 \\
4-5-82\end{array}$ & $\begin{array}{l}2.26 \\
1.67 \\
2.04 \\
1.71\end{array}$ & $\begin{array}{l}5-4-82 \\
6-1-82 \\
7-782\end{array}$ & $\begin{array}{l}2.08 \\
3.13 \\
2.57\end{array}$ & $\begin{array}{r}8-2-82 \\
9-13-82 \\
10-18-82\end{array}$ & $\begin{array}{l}2.53 \\
2.07 \\
2.45\end{array}$ \\
\hline
\end{tabular}

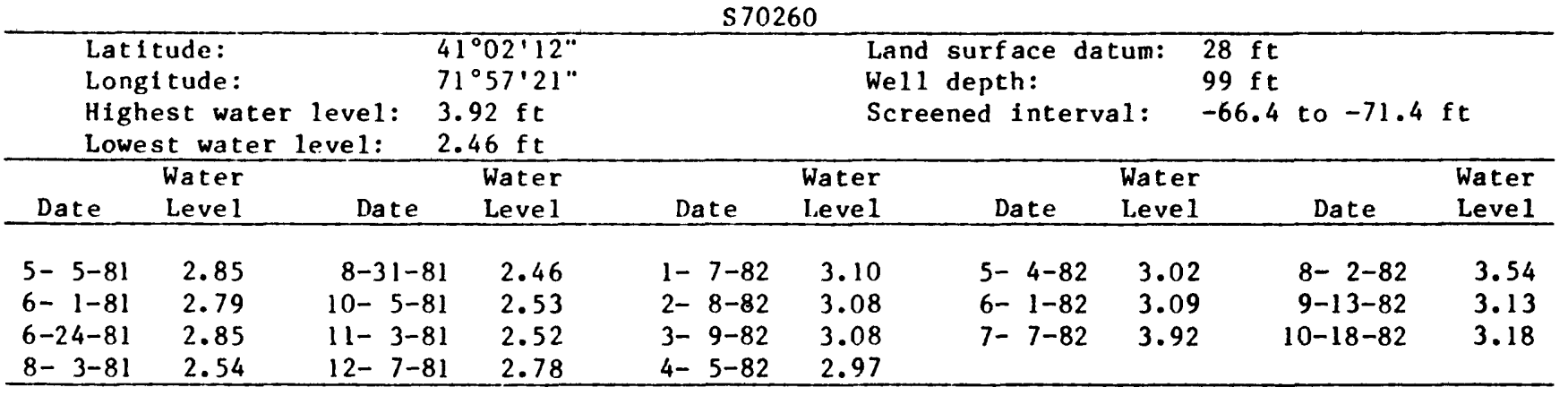

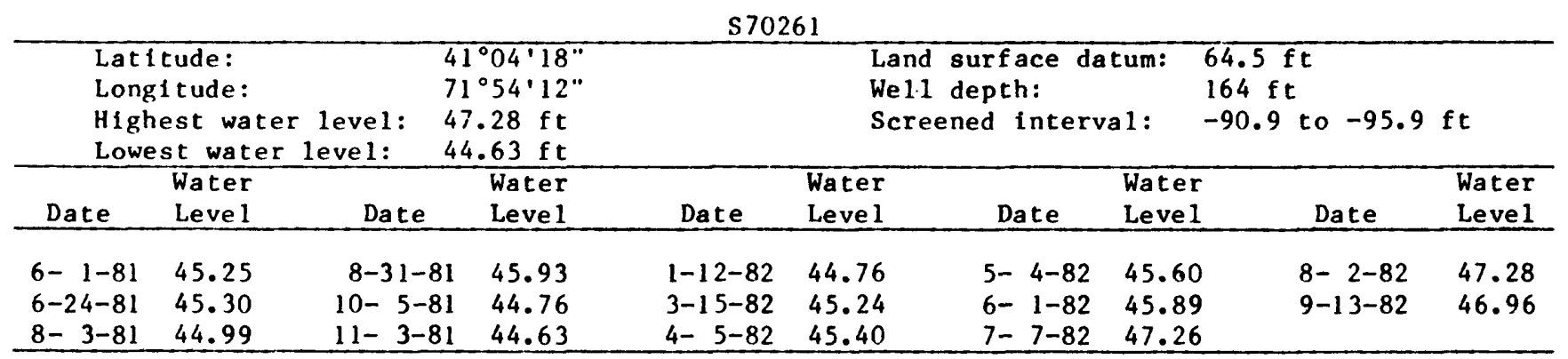


Table 11.-Water levels in the Montauk area, Long Island, N.Y.--continued

[Well locations are shown in pl. 1; water levels are in feet above sea level; some measurements from Suffolk County Department of Health Services.]

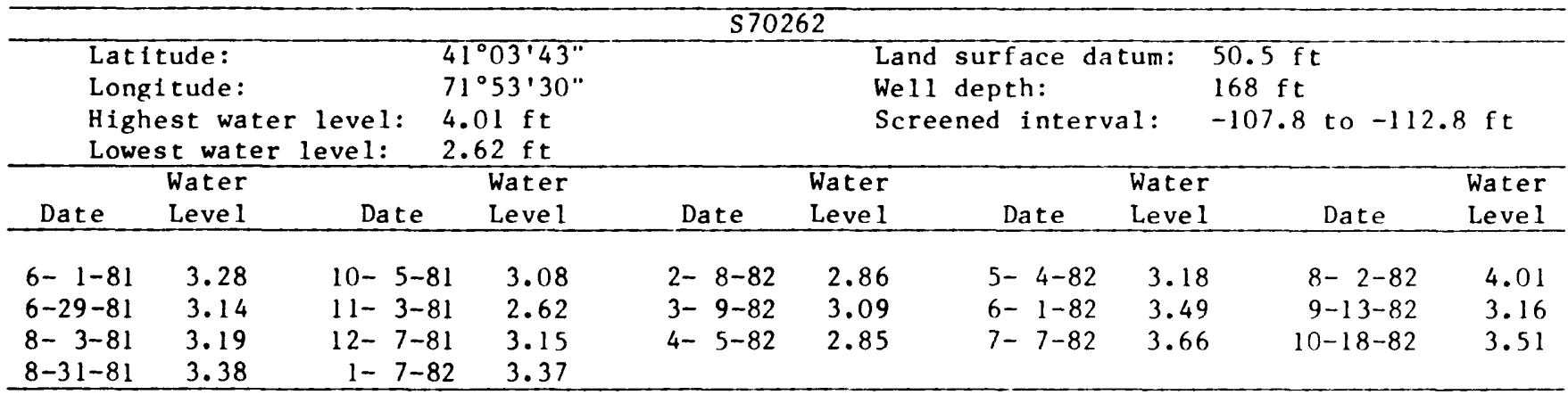

570263

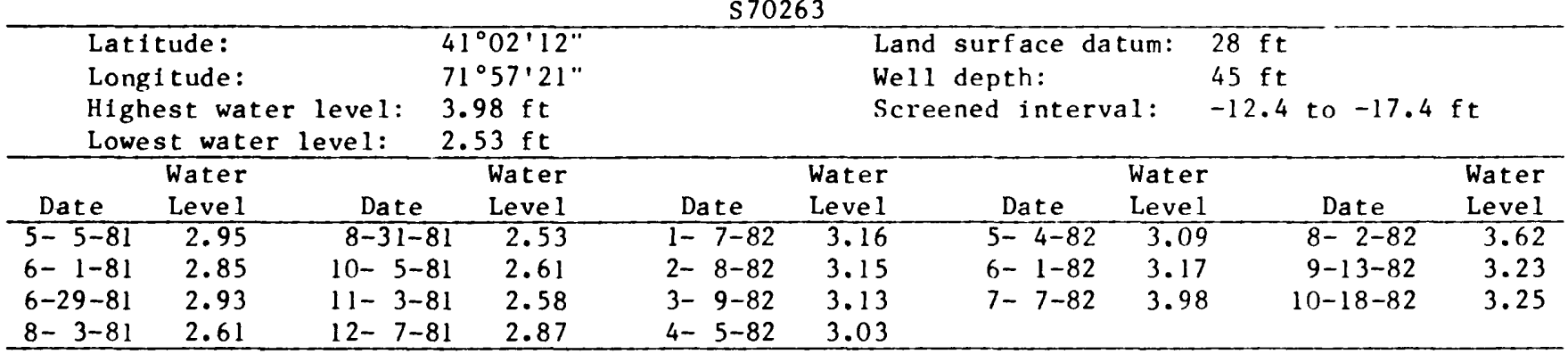

570264

\begin{tabular}{|c|c|c|c|c|c|c|c|c|c|c|}
\hline \multicolumn{2}{|c|}{$\begin{array}{l}\text { Latitude: } \\
\text { Longi tude: }\end{array}$} & $\begin{array}{l}\text { leve 1: } \\
\text { eve1: }\end{array}$ & $\begin{array}{l}41^{\circ} 01^{\prime} 39^{\prime \prime} \\
72^{\circ} 00^{\prime} 14^{\prime \prime}\end{array}$ & & & $\begin{array}{l}\text { urface da } \\
\text { epth: } \\
\text { ed interv }\end{array}$ & I: & $\begin{array}{l}27 \mathrm{ft} \\
40 \mathrm{ft} \\
-8.4\end{array}$ & to -13.4 & \\
\hline & Water & & Water & & Water & & Water & & & Water \\
\hline Date & Leve 1 & Date & Leve 1 & Date & Leve 1 & Date & Level & & Date & Level \\
\hline $3-26-81$ & 2.52 & $8-3-81$ & 2.69 & $12-7-81$ & 2.41 & $4-5-82$ & 2.74 & & $8-2-82$ & 5.01 \\
\hline $5-5-81$ & 2.52 & $8-31-81$ & 2.64 & $1-7-82$ & 2.35 & $5-4-82$ & 2.86 & & $9-13-82$ & 4.33 \\
\hline $6-1-81$ & 2.69 & $10-5-81$ & 2.53 & $2-8-82$ & 2.37 & $6-1-82$ & 3.08 & & $10-18-82$ & 3.96 \\
\hline $6-24-81$ & 2.74 & $11-3-81$ & 2.40 & $3-9-82$ & 2.68 & $7-7-82$ & 5.39 & & & \\
\hline
\end{tabular}

570614

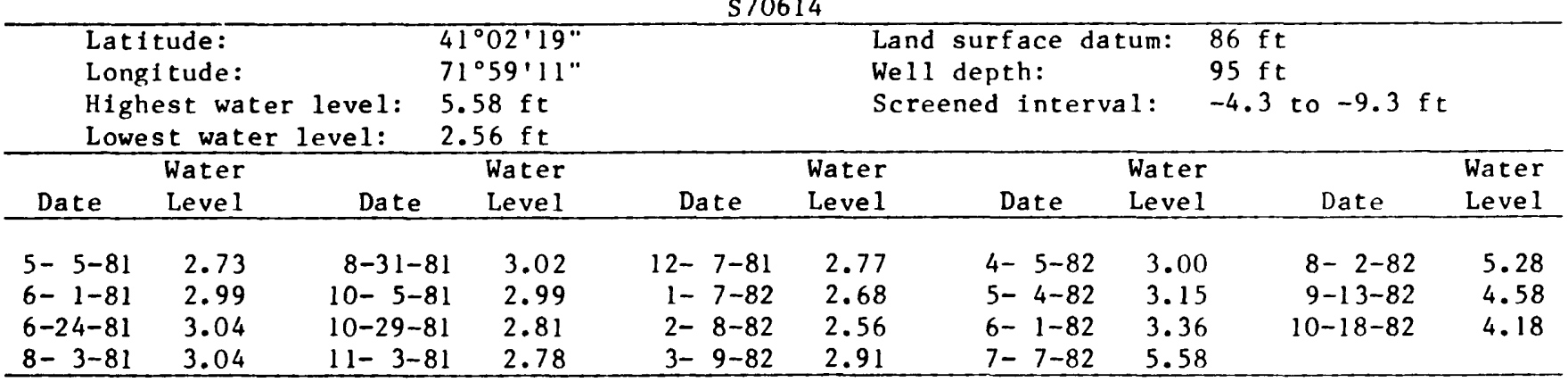


Table 11.--Water levels in the Montauk area, Long Island, N.Y.--continued

[We11 locations are shown in pl. 1; water levels are in feet above sea level; some measurements from Suffolk County Department of Health Services.]

\begin{tabular}{|c|c|c|c|c|c|c|c|c|c|}
\hline \multicolumn{10}{|c|}{$S 70615$} \\
\hline $\begin{array}{l}\text { High } \\
\text { Lowe }\end{array}$ & $\begin{array}{l}\text { est water } \\
\text { st water }\end{array}$ & $\begin{array}{l}\text { level: } \\
\text { level: }\end{array}$ & $\begin{array}{l}72 \mathrm{ft} \\
53 \mathrm{ft}\end{array}$ & & & ed inter & 1: & 1 to $-4 \mathrm{ft}$ & \\
\hline & Water & & Water & & Water & & Water & & Water \\
\hline Date & Leve 1 & Date & Leve 1 & Date & Leve I & Date & Leve 1 & Date & Level \\
\hline $6-1-81$ & 2.03 & $10-5-81$ & 2.56 & $2-8-82$ & 1.53 & $6-1-82$ & 2.63 & $10-18-82$ & 2.72 \\
\hline $6-29-81$ & 1.77 & $11-3-81$ & 2.13 & $3-9-82$ & 2.33 & $7-7-82$ & 2.09 & & \\
\hline
\end{tabular}

570616

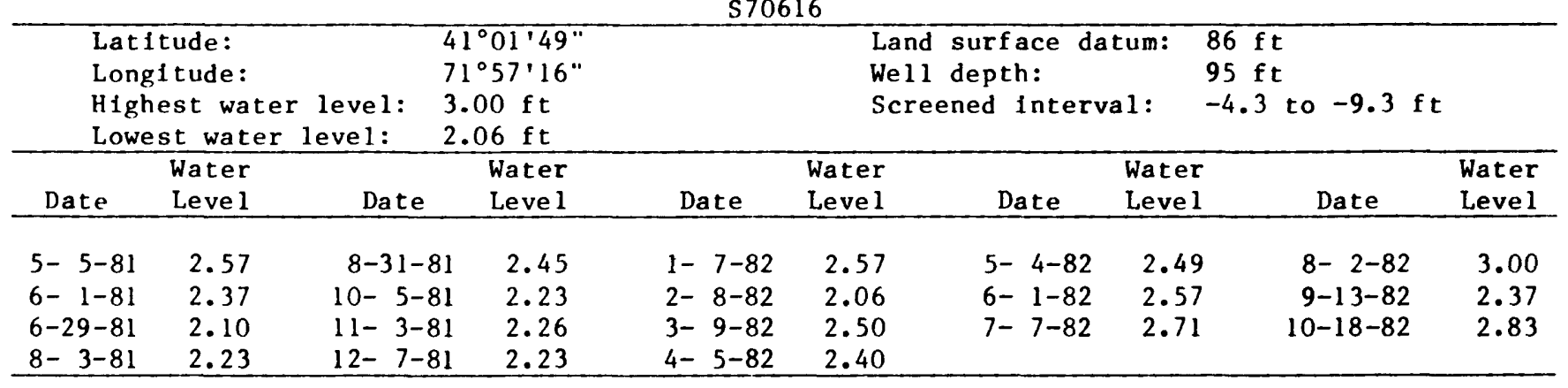

s70617

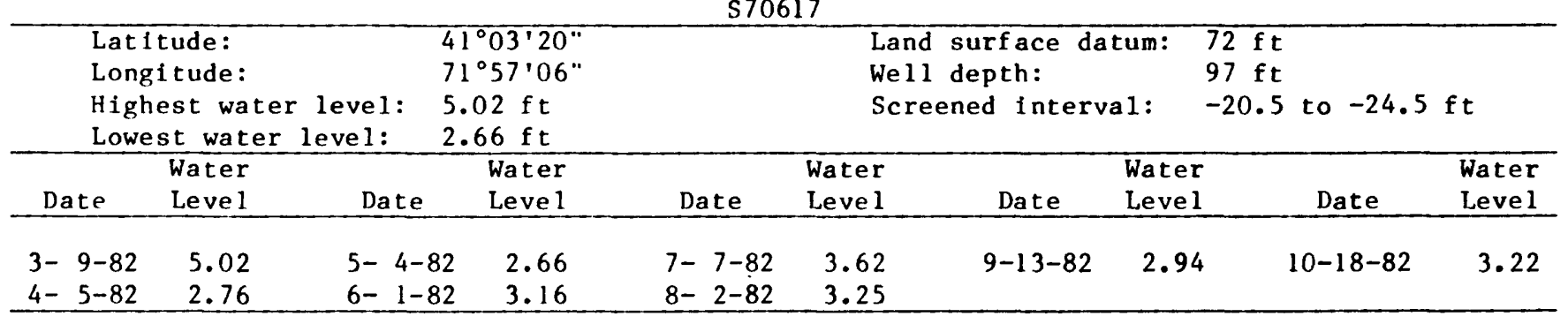

S70618

\begin{tabular}{|c|c|c|c|c|c|c|c|c|c|}
\hline $\begin{array}{l}\text { Lat } 1 \\
\text { Long } \\
\text { High } \\
\text { Lowe }\end{array}$ & $\begin{array}{l}\text { tude: } \\
\text { itude: } \\
\text { est wate } \\
\text { st water }\end{array}$ & $\begin{array}{l}\text { leve 1: } \\
\text { eve 1: }\end{array}$ & $\begin{array}{l}{ }^{\circ} 03^{\prime} 30^{\prime \prime} \\
\circ 56^{\prime} 39 " \\
28 \mathrm{ft} \\
39 \mathrm{ft}\end{array}$ & & & $\begin{array}{l}\text { arface da } \\
\text { epth: } \\
\text { ed inter }\end{array}$ & 1: & $\begin{array}{l}96.0 \mathrm{ft} \\
105 \mathrm{ft} \\
-14.7 \text { to }-19.7\end{array}$ & $\mathrm{ft}$ \\
\hline $\begin{array}{l}5-5-81 \\
6-1-81 \\
6-24-81 \\
8-3-81\end{array}$ & $\begin{array}{l}2.94 \\
2.73 \\
2.62 \\
2.39\end{array}$ & $\begin{array}{r}8-31-81 \\
10-5-81 \\
11-3-81 \\
12-7-81\end{array}$ & $\begin{array}{l}2.66 \\
2.70 \\
2.58 \\
2.87\end{array}$ & $\begin{array}{l}1-7-82 \\
2-8-82 \\
3-9-82 \\
4-5-82\end{array}$ & $\begin{array}{l}3.00 \\
2.52 \\
2.91 \\
2.58\end{array}$ & $\begin{array}{l}5-4-82 \\
6-1-82 \\
7-7-82\end{array}$ & $\begin{array}{l}2.66 \\
2.89 \\
3.11\end{array}$ & $\begin{array}{r}8-2-82 \\
9-13-82 \\
10-18-82\end{array}$ & $\begin{array}{l}3.11 \\
2.72 \\
3.28\end{array}$ \\
\hline
\end{tabular}


Table 11.-Water levels in the Montauk area, Long Island, N.Y.--continued

[Wel1 locations are shown in pl. 1; water levels are in feet above sea level; some measurements from Suffolk County Department of Health Services.]

S 70619

\begin{tabular}{|c|c|c|c|c|c|c|c|c|c|}
\hline \multicolumn{3}{|c|}{$\begin{array}{l}\text { Lat ftude: } \\
\text { Longitude: } \\
\text { Highest water level: } \\
\text { Lowest water level: }\end{array}$} & $\begin{array}{l}41^{\circ} 03^{\prime} 17^{\prime \prime} \\
71^{\circ} 55^{\prime} 59^{\prime \prime} \\
8.04 \mathrm{ft} \\
3.45 \mathrm{ft}\end{array}$ & & \multicolumn{3}{|c|}{$\begin{array}{l}\text { Land surface datum: } \\
\text { Well depth: } \\
\text { Screened interval: }\end{array}$} & $\begin{array}{l}12.3 \mathrm{ft} \\
12 \mathrm{ft} \\
4.6 \text { to }-.35\end{array}$ & \\
\hline Date & $\begin{array}{l}\text { Water } \\
\text { Leve } 1 \\
\end{array}$ & Date & $\begin{array}{l}\text { Water } \\
\text { Level } \\
\end{array}$ & Date & $\begin{array}{l}\text { Water } \\
\text { Level }\end{array}$ & Date & $\begin{array}{l}\text { Water } \\
\text { Level }\end{array}$ & Date & $\begin{array}{l}\text { Water } \\
\text { Level }\end{array}$ \\
\hline $\begin{array}{l}5-5-81 \\
6-1-81 \\
6-24-81 \\
8-3-81\end{array}$ & $\begin{array}{l}6.90 \\
5.80 \\
5.72 \\
4.22\end{array}$ & $\begin{array}{r}8-31-81 \\
10-5-81 \\
11-3-81 \\
12-7-81\end{array}$ & $\begin{array}{l}3.45 \\
3.53 \\
3.66 \\
5.14\end{array}$ & $\begin{array}{l}1-7-82 \\
2-8-82 \\
3-9-82 \\
4-5-82 \\
\end{array}$ & $\begin{array}{l}7.70 \\
8.04 \\
7.80 \\
7.40 \\
\end{array}$ & $\begin{array}{l}5-4-82 \\
6-1-82 \\
7-7-82\end{array}$ & $\begin{array}{l}7.25 \\
6.93 \\
7.41\end{array}$ & $\begin{array}{r}8-2-82 \\
9-13-82 \\
10-18-82\end{array}$ & $\begin{array}{l}5.65 \\
4.59 \\
4.14\end{array}$ \\
\hline
\end{tabular}

S70620

\begin{tabular}{|c|c|c|c|c|c|c|c|c|c|}
\hline \multicolumn{2}{|c|}{$\begin{array}{l}\text { Lat itude: } \\
\text { Long } 1 \text { tude: }\end{array}$} & \multicolumn{2}{|c|}{$\begin{array}{l}41^{\circ} 03^{\prime} 02^{\prime \prime} \\
71^{\circ} 56^{\prime} 28^{\prime \prime}\end{array}$} & & \multicolumn{3}{|c|}{$\begin{array}{l}\text { Land surface datum: } \\
\text { We } 11 \text { depth: }\end{array}$} & $\begin{array}{l}47.2 \mathrm{ft} \\
50 \mathrm{ft} \\
2.4 \mathrm{to}-2.6 \mathrm{ft}\end{array}$ & \\
\hline Date & $\begin{array}{l}\text { Water } \\
\text { Level }\end{array}$ & Date & $\begin{array}{l}\text { Water } \\
\text { Leve 1 }\end{array}$ & Date & $\begin{array}{l}\text { Water } \\
\text { Leve1 }\end{array}$ & Date & $\begin{array}{l}\text { Water } \\
\text { Leve } 1\end{array}$ & Date & $\begin{array}{l}\text { Water } \\
\text { Leve } 1\end{array}$ \\
\hline $\begin{array}{l}5-5-81 \\
6-1-81 \\
6-24-81 \\
8-3-81\end{array}$ & $\begin{array}{l}37.38 \\
36.73 \\
36.53 \\
36.19\end{array}$ & $\begin{array}{r}8-31-81 \\
10-5-81 \\
11-3-81 \\
12-7-81\end{array}$ & $\begin{array}{l}36.82 \\
36.68 \\
35.02 \\
35.09\end{array}$ & $\begin{array}{l}1-7-82 \\
2-8-82 \\
3-9-82 \\
4-5-82\end{array}$ & $\begin{array}{l}35.85 \\
35.70 \\
36.03 \\
38.16\end{array}$ & $\begin{array}{l}5-4-82 \\
6-1-82 \\
7-7-82\end{array}$ & $\begin{array}{l}38.47 \\
38.29 \\
40.49\end{array}$ & $\begin{array}{r}8-2-82 \\
9-13-82 \\
10-18-82\end{array}$ & $\begin{array}{l}39.29 \\
38.03 \\
37.51\end{array}$ \\
\hline
\end{tabular}

S70621

\begin{tabular}{|c|c|c|c|c|c|c|c|c|c|}
\hline $\begin{array}{l}\text { Lat } \\
\text { Long } \\
\text { H1gh } \\
\text { Lowe }\end{array}$ & $\begin{array}{l}\text { tude: } \\
\text { itude: } \\
\text { est wate } \\
\text { st water }\end{array}$ & $\begin{array}{l}\text { eve 1: } \\
\text { ve 1: }\end{array}$ & $\begin{array}{l}.02^{\prime} 09^{\prime \prime} \\
.56^{\prime} 00^{\prime \prime} \\
.28 \mathrm{ft} \\
.57 \mathrm{ft} \\
\end{array}$ & & & $\begin{array}{l}\text { rface d } \\
\text { pth: } \\
\text { d Inter }\end{array}$ & im: & $\begin{array}{l}44.2 \mathrm{ft} \\
51 \mathrm{ft} \\
-1.9 \text { to }-6.9 \mathrm{ft}\end{array}$ & \\
\hline Date & $\begin{array}{l}\text { Water } \\
\text { Leve } 1 \\
\end{array}$ & Date & $\begin{array}{l}\text { Water } \\
\text { Leve } 1 \\
\end{array}$ & Date & $\begin{array}{l}\text { Water } \\
\text { Leve } 1 \\
\end{array}$ & Date & $\begin{array}{l}\text { Water } \\
\text { Leve } 1 \\
\end{array}$ & 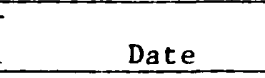 & $\begin{array}{l}\text { Water } \\
\text { Leve } 1\end{array}$ \\
\hline $\begin{array}{l}5-5-81 \\
6-1-81 \\
6-24-81 \\
8-3-81\end{array}$ & $\begin{array}{l}4.09 \\
3.57 \\
4.15 \\
4.72\end{array}$ & $\begin{array}{r}8-31-81 \\
10-5-81 \\
10-29-81 \\
11-3-81 \\
\end{array}$ & $\begin{array}{l}4.82 \\
4.52 \\
4.39 \\
4.45\end{array}$ & $\begin{array}{r}12-7-81 \\
1-7-82 \\
2-8-82 \\
3-9-82 \\
\end{array}$ & $\begin{array}{l}4.69 \\
4.94 \\
5.53 \\
6.62 \\
\end{array}$ & $\begin{array}{l}4-5-82 \\
5-4-82 \\
6-1-82 \\
7-7-82 \\
\end{array}$ & $\begin{array}{r}7.98 \\
9.43 \\
10.13 \\
11.86 \\
\end{array}$ & $\begin{array}{r}8-2-82 \\
9-13-82 \\
10-18-82\end{array}$ & $\begin{array}{r}12.28 \\
10.92 \\
9.92\end{array}$ \\
\hline
\end{tabular}

S 70622

\begin{tabular}{|c|c|c|c|c|c|c|c|c|c|c|}
\hline $\begin{array}{l}\text { Lat } \\
\text { Long } \\
\text { High } \\
\text { Lowe }\end{array}$ & $\begin{array}{l}\text { tude: } \\
\text { itude: } \\
\text { est wate } \\
\text { st water }\end{array}$ & $\begin{array}{l}\text { eve 1: } \\
\text { ve 1: }\end{array}$ & $\begin{array}{l}.54 \cdot 37^{\circ} \\
26 \mathrm{ft} \\
47 \mathrm{ft} \\
\end{array}$ & & & $\begin{array}{l}\text { epth: } \\
\text { ed inter }\end{array}$ & um: & $\begin{array}{l}31 \mathrm{ft} \\
55 \mathrm{ft} \\
-19.5\end{array}$ & to -24.5 & $\mathrm{ft}$ \\
\hline Date & $\begin{array}{l}\text { Water } \\
\text { Level }\end{array}$ & Date & $\begin{array}{l}\text { Water } \\
\text { Leve } 1\end{array}$ & Date & $\begin{array}{l}\text { Water } \\
\text { Leve } 1 \\
\end{array}$ & Date & $\begin{array}{l}\text { Water } \\
\text { Leve } 1\end{array}$ & & Date & $\begin{array}{l}\text { Water } \\
\text { Leve } 1\end{array}$ \\
\hline $\begin{array}{l}5-5-81 \\
6-1-81 \\
6-24-81 \\
8-3-81\end{array}$ & $\begin{array}{l}2.08 \\
1.77 \\
2.23 \\
2.06\end{array}$ & $\begin{array}{r}8-31-81 \\
10-5-81 \\
11-3-81\end{array}$ & $\begin{array}{l}2.21 \\
2.06 \\
1.83\end{array}$ & $\begin{array}{r}12-7-81 \\
1-7-82 \\
2-8-82\end{array}$ & $\begin{array}{l}1.88 \\
2.09 \\
1.47\end{array}$ & $\begin{array}{l}3-9-82 \\
4-5-82 \\
5-4-82\end{array}$ & $\begin{array}{l}1.78 \\
1.47 \\
1.85\end{array}$ & & $\begin{array}{r}6-1-82 \\
9-13-82 \\
10-18-82\end{array}$ & $\begin{array}{l}2.26 \\
1.74 \\
2.22\end{array}$ \\
\hline
\end{tabular}


Table 11.-Water levels in the Montauk area, Long Island, N.Y.--continued

[Wel1 locations are shown in pl. 1; water levels are in feet above sea level; some measurements from Suffolk County Department of Health Services.]

\begin{tabular}{|c|c|c|c|c|c|c|c|c|c|}
\hline \multicolumn{10}{|c|}{570623} \\
\hline \multicolumn{3}{|c|}{$\begin{array}{l}\text { Latitude: } \\
\text { Longitude: } \\
\text { Highest water level: } \\
\text { Lowest water level: }\end{array}$} & $\begin{array}{l}41^{\circ} 04^{\prime} 53^{\prime \prime} \\
71^{\circ} 54^{\prime} 30^{\prime \prime} \\
2.04 \mathrm{ft} \\
1.07 \mathrm{ft} \\
\end{array}$ & & \multicolumn{3}{|c|}{$\begin{array}{l}\text { Land surface datum: } \\
\text { Well depth: } \\
\text { Screened interval: }\end{array}$} & $\begin{array}{l}4.5 \mathrm{ft} \\
35 \mathrm{ft} \\
-25.7 \text { to }-30.7\end{array}$ & \\
\hline Date & $\begin{array}{l}\text { Water } \\
\text { Leve I }\end{array}$ & Date & $\begin{array}{l}\text { Water } \\
\text { Level }\end{array}$ & Date & $\begin{array}{l}\text { Water } \\
\text { Leve } 1 \\
\end{array}$ & Date & $\begin{array}{l}\text { Water } \\
\text { Leve } 1 \\
\end{array}$ & Date & $\begin{array}{l}\text { Water } \\
\text { Level } \\
\end{array}$ \\
\hline $\begin{array}{l}5-5-81 \\
6-1-81 \\
6-24-81 \\
8-3-81\end{array}$ & $\begin{array}{l}2.04 \\
1.39 \\
1.35 \\
1.28\end{array}$ & $\begin{array}{l}8-31-8 \\
10-5-8 \\
11-3-8\end{array}$ & $\begin{array}{l}1.54 \\
1.29 \\
1.37\end{array}$ & $\begin{array}{l}1-12-82 \\
3-15-82 \\
4-5-82\end{array}$ & $\begin{array}{l}1.78 \\
1.35 \\
1.49\end{array}$ & $\begin{array}{l}5-4-82 \\
6-1-82 \\
7-7-82\end{array}$ & $\begin{array}{l}1.41 \\
1.58 \\
1.51\end{array}$ & $\begin{array}{r}8-2-82 \\
9-13-82 \\
10-18-82\end{array}$ & $\begin{array}{l}1.54 \\
1.07 \\
1.82\end{array}$ \\
\hline
\end{tabular}

570624

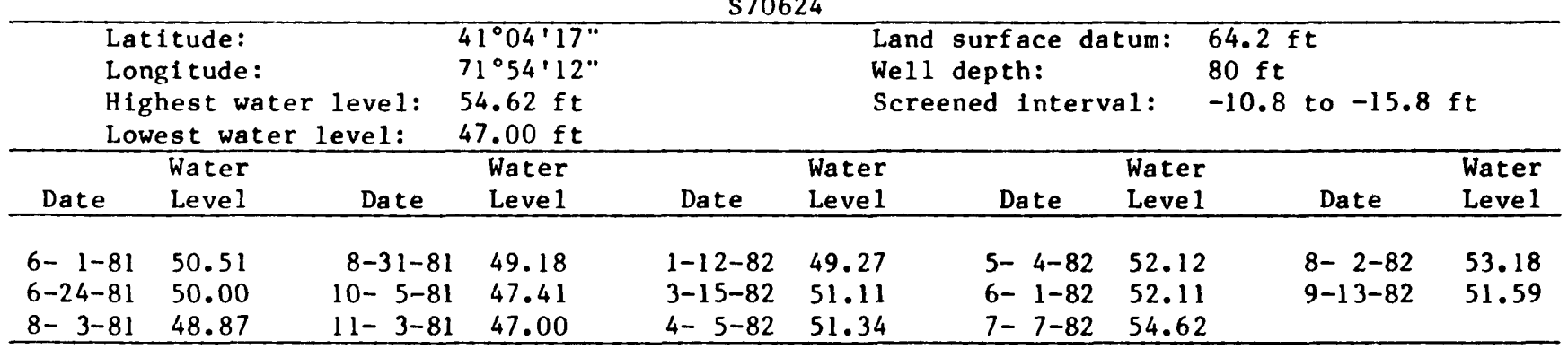

570625

\begin{tabular}{|c|c|c|c|c|c|c|c|c|c|}
\hline \multicolumn{3}{|c|}{$\begin{array}{l}\text { Latitude: } \\
\text { Longitude: } \\
\text { Highest water leve1: } \\
\text { Lowest water level: } \\
\text { Water }\end{array}$} & \multirow{2}{*}{$\begin{array}{l}41^{\circ} 03^{\prime} 43^{\prime \prime} \\
71^{\circ} 53^{\prime} 29^{\circ} \\
18.54 \mathrm{ft} \\
13.65 \mathrm{ft} \\
\text { Water } \\
\text { Leve } 1\end{array}$} & & \multicolumn{3}{|c|}{$\begin{array}{l}\text { Land surface datum: } \\
\text { Well depth: } \\
\text { Screened interva1: }\end{array}$} & $\begin{array}{l}50.4 \mathrm{ft} \\
54 \mathrm{ft} \\
1.3 \text { to }-3.7 \mathrm{ft}\end{array}$ & \\
\hline Date & $\begin{array}{l}\text { Water } \\
\text { Leve } 1 \\
\end{array}$ & Date & & Date & $\begin{array}{l}\text { Water } \\
\text { Leve } 1\end{array}$ & $e$ & $\begin{array}{l}\text { Water } \\
\text { Leve } 1\end{array}$ & $\begin{array}{l}r \\
1\end{array}$ & $\begin{array}{l}\text { Water } \\
\text { Leve } 1 \\
\end{array}$ \\
\hline $\begin{array}{l}5-5-81 \\
6-1-81 \\
6-29-81 \\
8-3-81\end{array}$ & $\begin{array}{l}14.79 \\
14.61 \\
14.67 \\
14.76\end{array}$ & $\begin{array}{r}8-31-82 \\
10-5-81 \\
11-3-81 \\
12-7-81\end{array}$ & $\begin{array}{l}15.19 \\
14.37 \\
14.15 \\
13.89\end{array}$ & $\begin{array}{l}1-7-82 \\
2-8-82 \\
3-9-82 \\
4-5-82\end{array}$ & $\begin{array}{l}13.69 \\
13.65 \\
14.14 \\
14.54\end{array}$ & $\begin{array}{l}5-4-82 \\
6-1-82 \\
7-7-82\end{array}$ & $\begin{array}{l}15.18 \\
15.89 \\
18.08\end{array}$ & $\begin{array}{r}8-2-82 \\
9-13-82 \\
10-18-82\end{array}$ & $\begin{array}{l}18.54 \\
18.10 \\
17.43\end{array}$ \\
\hline
\end{tabular}

S70626

\begin{tabular}{|c|c|c|c|c|c|c|c|c|c|}
\hline \multicolumn{3}{|c|}{$\begin{array}{l}\text { Latitude: } \\
\text { Longitude: } \\
\text { Highest water level: } \\
\text { Lowest water level: }\end{array}$} & $\begin{array}{l}41^{\circ} 03^{\prime} 20^{\prime \prime} \\
71^{\circ} 52^{\prime} 40^{\prime \prime} \\
47.14 \mathrm{ft} \\
40.14 \mathrm{ft}\end{array}$ & & \multicolumn{3}{|c|}{$\begin{array}{l}\text { Land surface datum: } \\
\text { We11 depth: } \\
\text { Screened interval: }\end{array}$} & $\begin{array}{l}59.2 \mathrm{ft} \\
60 \mathrm{ft} \\
4.0 \text { to }-1.0 \mathrm{ft}\end{array}$ & \\
\hline Date & $\begin{array}{l}\text { Water } \\
\text { Level }\end{array}$ & Date & $\begin{array}{l}\text { Water } \\
\text { Leve } 1 \\
\end{array}$ & Date & $\begin{array}{l}\text { Water } \\
\text { Leve } 1 \\
\end{array}$ & Da & $\begin{array}{l}\text { Water } \\
\text { Leve } 1 \\
\end{array}$ & Da & $\begin{array}{l}\text { Water } \\
\text { Level }\end{array}$ \\
\hline $\begin{array}{l}5-5-81 \\
6-1-81 \\
6-29-81 \\
8-3-81\end{array}$ & $\begin{array}{l}42.68 \\
43.10 \\
42.65 \\
42.36\end{array}$ & $\begin{array}{l}8-31-81 \\
10-5-81 \\
11-3-81 \\
12-7-81\end{array}$ & $\begin{array}{l}43.55 \\
41.67 \\
40.22 \\
40.14\end{array}$ & $\begin{array}{l}1-7-82 \\
2-8-82 \\
3-9-82 \\
4-5-82\end{array}$ & $\begin{array}{l}40.41 \\
40.68 \\
43.12 \\
44.30\end{array}$ & $\begin{array}{l}5-4-82 \\
6-1-82 \\
7-7-82\end{array}$ & $\begin{array}{l}45.12 \\
44.30 \\
47.14\end{array}$ & $\begin{array}{r}8-2-82 \\
9-13-82 \\
10-18-82\end{array}$ & $\begin{array}{l}45.22 \\
43.12 \\
42.00\end{array}$ \\
\hline
\end{tabular}


Table 11.-Water levels in the Montauk area, Long Island, N.Y.--continued

[Well locations are shown in pl. 1; water levels are in feet above sea leve1; some measurements from Suffolk County Department of Health Services.]

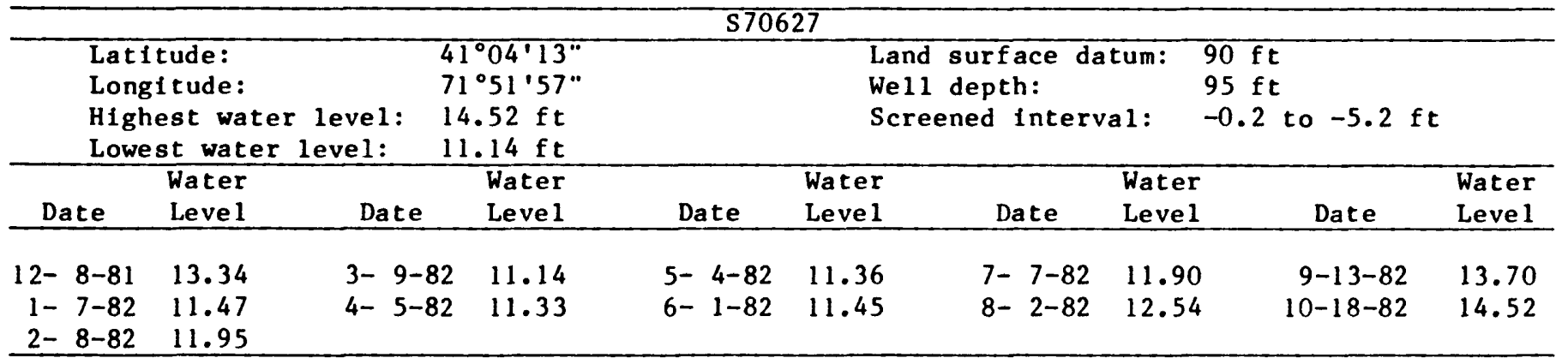

S72283

\begin{tabular}{|c|c|c|c|c|c|c|c|c|c|}
\hline $\begin{array}{l}\text { Lat } \\
\text { Long } \\
\text { Higl } \\
\text { Lowe }\end{array}$ & $\begin{array}{l}\text { tude: } \\
\text { itude: } \\
\text { est wate } \\
\text { st water }\end{array}$ & $\begin{array}{cc} & 41 \\
& 71 \\
\text { r level: } & 3 . \\
\text { level: } & 1 .\end{array}$ & $\begin{array}{l}{ }^{\circ} 03^{\prime} 20^{\prime \prime} \\
{ }^{\circ} 52^{\prime} 40^{\prime \prime} \\
88 \mathrm{ft} \\
82 \mathrm{ft}\end{array}$ & & $\begin{array}{l}\mathrm{L} \\
W \\
\mathrm{~S}\end{array}$ & $\begin{array}{l}\text { urface da } \\
\text { epth: } \\
\text { ed interv }\end{array}$ & $\begin{array}{l}\text { tum: } \\
\text { al: }\end{array}$ & $\begin{array}{l}58.5 \mathrm{ft} \\
89 \mathrm{ft} \\
-25.4 \text { to }-30.4\end{array}$ & $f t$ \\
\hline Date & $\begin{array}{l}\text { Water } \\
\text { Leve } 1\end{array}$ & Date & $\begin{array}{l}\text { Water } \\
\text { Leve } 1\end{array}$ & Date & $\begin{array}{l}\text { Water } \\
\text { Leve } 1\end{array}$ & Date & $\begin{array}{l}\text { Water } \\
\text { Level }\end{array}$ & Date & $\begin{array}{l}\text { Water } \\
\text { Level }\end{array}$ \\
\hline $\begin{array}{l}1-7-82 \\
2-8-82\end{array}$ & $\begin{array}{l}1.99 \\
3.28\end{array}$ & $\begin{array}{l}3-9-82 \\
4-5-82\end{array}$ & $\begin{array}{l}1.93 \\
2.21\end{array}$ & $\begin{array}{l}5-4-82 \\
6-1-82\end{array}$ & $\begin{array}{l}2.34 \\
3.88\end{array}$ & $\begin{array}{l}7-7-82 \\
8-2-82\end{array}$ & $\begin{array}{l}2.22 \\
2.34\end{array}$ & $\begin{array}{r}9-13-82 \\
10-18-82\end{array}$ & $\begin{array}{l}1.82 \\
2.61\end{array}$ \\
\hline
\end{tabular}

S72415

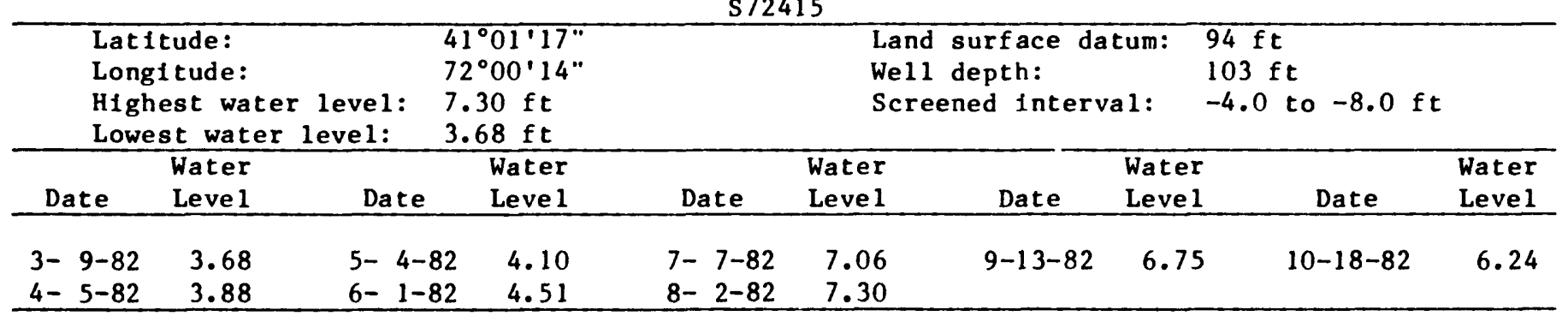

S72416

\begin{tabular}{|c|c|c|c|c|c|c|c|c|c|}
\hline $\begin{array}{l}\text { Lat } \\
\text { Long } \\
\text { High } \\
\text { Lowe }\end{array}$ & $\begin{array}{l}\text { Latitude: } \\
\text { Long } 1 \text { tude: }\end{array}$ & $\begin{array}{l}\text { eve 1: } \\
\text { vel: }\end{array}$ & $\begin{array}{l}{ }^{\circ} 02^{\prime} 09^{\prime \prime} \\
\circ 56^{\circ} 00^{\prime \prime} \\
16 \mathrm{ft} \\
21 \mathrm{ft}\end{array}$ & & \multicolumn{2}{|c|}{$\begin{array}{l}\text { Land surface datum: } \\
\text { Well depth: }\end{array}$} & $\begin{array}{l}\text { tum: } \\
\text { a 1: }\end{array}$ & $\begin{array}{l}44.2 \mathrm{ft} \\
97 \mathrm{ft} \\
-48.9 \text { to }-52.9\end{array}$ & $\mathrm{ft}$ \\
\hline Date & $\begin{array}{l}\text { Water } \\
\text { Leve } 1 \\
\end{array}$ & Date & $\begin{array}{l}\text { Water } \\
\text { Leve } 1 \\
\end{array}$ & Date & $\begin{array}{l}\text { Water } \\
\text { Leve } 1 \\
\end{array}$ & Date & $\begin{array}{l}\text { Water } \\
\text { Leve } 1 \\
\end{array}$ & Date & $\begin{array}{l}\text { Water } \\
\text { Leve } 1\end{array}$ \\
\hline $\begin{array}{l}3-9-82 \\
4-5-82\end{array}$ & $\begin{array}{l}1.45 \\
1.21\end{array}$ & $\begin{array}{l}5-4-82 \\
6-1-82\end{array}$ & $\begin{array}{l}1.44 \\
1.84\end{array}$ & $\begin{array}{l}7-7-82 \\
8-2-82\end{array}$ & $\begin{array}{l}1.86 \\
2.16\end{array}$ & $9-13-82$ & 1.88 & $10-18-82$ & 2.04 \\
\hline
\end{tabular}


Table 11.--Water levels in the Montauk area, Long Island, N.Y.--continued

[We11 locations are shown in pl. 1; water levels are in feet above sea leve1; some measurements from Suffolk County Department of Health Services.]

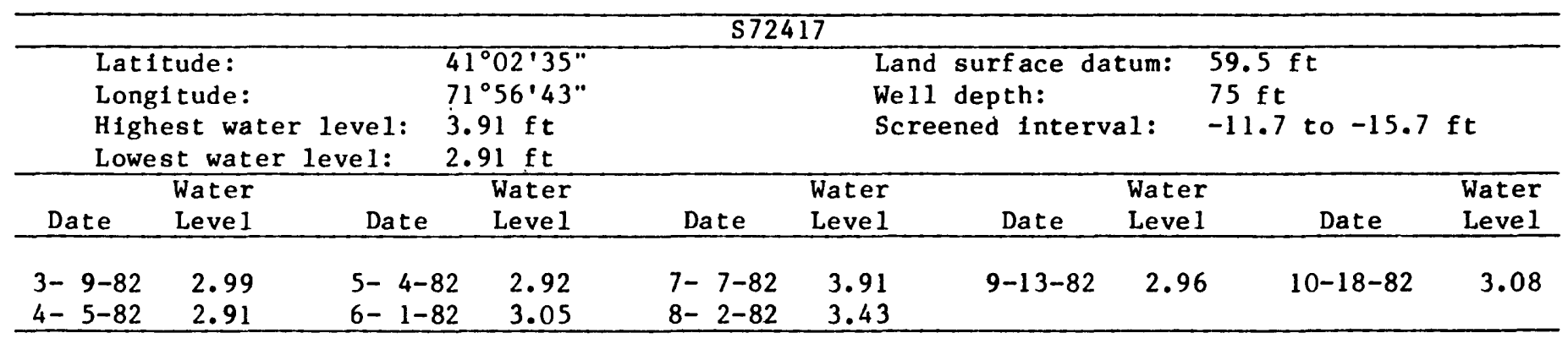

572418

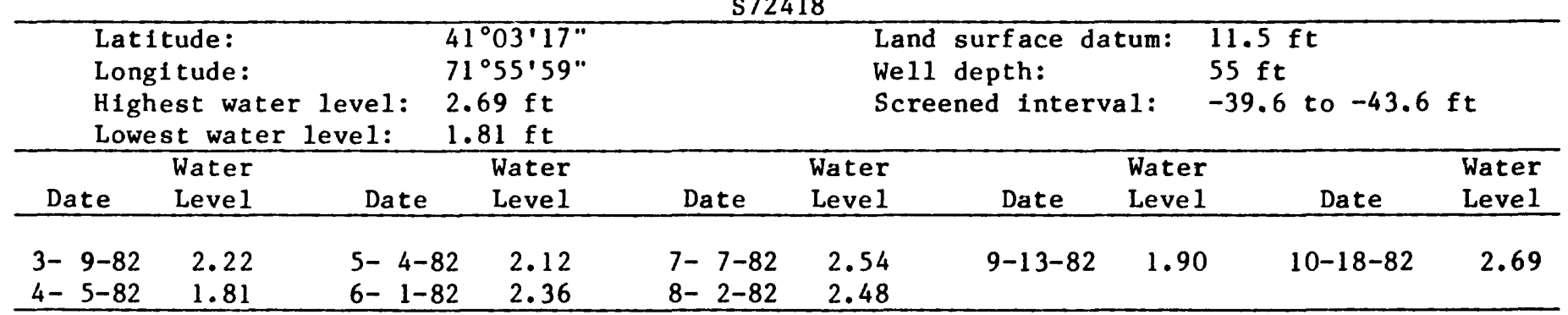

572419

\begin{tabular}{|c|c|c|c|c|c|c|c|c|c|}
\hline \multicolumn{2}{|c|}{$\begin{array}{l}\text { Latitude: } \\
\text { Longitude: }\end{array}$} & $\begin{array}{l}\text { eve 1: } \\
\text { ze 1: }\end{array}$ & $\begin{array}{l}{ }^{\circ} 02142^{\prime \prime} \\
055^{\prime} 43^{\circ} \\
34 \mathrm{ft} \\
10 \mathrm{ft}\end{array}$ & & & $\begin{array}{l}\text { Land surface datum: } \\
\text { We11 depth: }\end{array}$ & $\begin{array}{l}\text { tum: } \\
\text { a 1: }\end{array}$ & $\begin{array}{l}33.0 \mathrm{ft} \\
55 \mathrm{ft} \\
-17.6 \text { to }-22.6\end{array}$ & ft \\
\hline Date & $\begin{array}{l}\text { Water } \\
\text { Leve1 }\end{array}$ & Date & $\begin{array}{l}\text { Water } \\
\text { Leve1 }\end{array}$ & Date & $\begin{array}{l}\text { Water } \\
\text { Level }\end{array}$ & Date & $\begin{array}{l}\text { Water } \\
\text { Leve1 }\end{array}$ & Date & $\begin{array}{l}\text { Water } \\
\text { Leve1 }\end{array}$ \\
\hline $\begin{array}{l}4-5-82 \\
4-20-82\end{array}$ & $\begin{array}{l}2.10 \\
2.14\end{array}$ & $\begin{array}{l}5-4-82 \\
6-1-82\end{array}$ & $\begin{array}{l}2.33 \\
2.60\end{array}$ & $\begin{array}{l}7-7-82 \\
8-2-82\end{array}$ & $\begin{array}{l}2.84 \\
2.72\end{array}$ & $9-13-82$ & 2.23 & $10-18-82$ & 2.60 \\
\hline
\end{tabular}

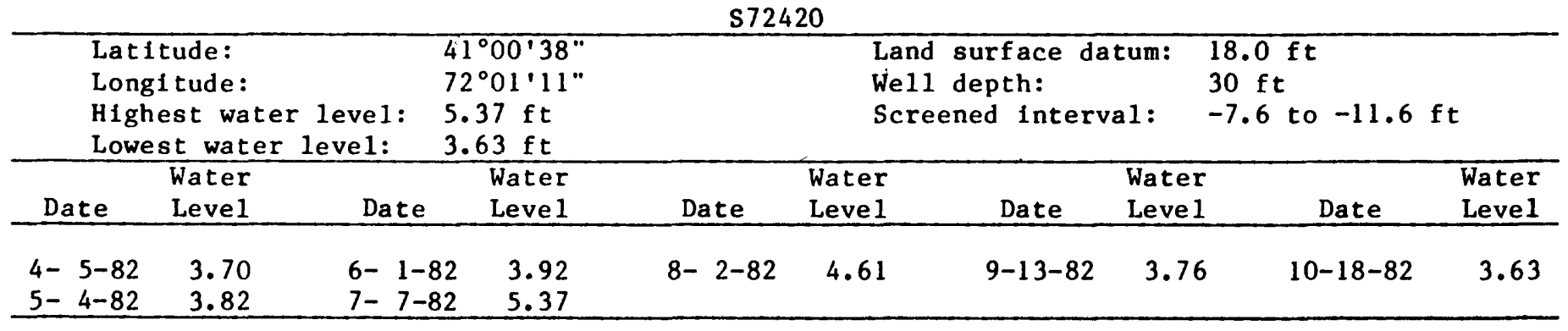

